\title{
TÜRANGaWAeWAE | A PLACE TO STAND
}

Te Kore | Chaos \& Potential

A thesis by Jonathan Morrish 
TÜRANGAWAE WAE

A PLACE TO STAND

\section{C6}

Whatungarongaro te tangata toitü te whenua

People are lost from sight but the land remains.

- Mäori proverb

a 120-point thesis submitted to the Victoria University of Wellington in partial fulfillment of the requirements for the degree of Master of Architecture (Professional)

Victoria University of Wellington

of Architecture

2021 


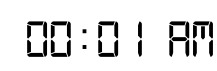

ABSTRACT

The landscape concealed beneath is replete with heritage stories representing the transformative evolution of the land, our culture and our ever-evolving society. The architecture upon these urban landscapes, however, is often only challenged to represent an architectural style (aesthetic), function (programme) or public mask (branding) of the building. As a result, architecture tends to neglect the evolving identity of its context, allowing the stories of the site's heritage to become lost beneath the growing layers of urban development. This thesis asks:

How can urban architecture help to reawaken the transformative heritage stories that form place identity, enabling architecture as well as its inhabitants to have a place to stand türangawaewae?

Place identity for Māori is embodied in the concept of tūrangawaewae - a place to stand. For Māori, the place where a person learns important life lessons and feels a connection with their ancestors is usually the marae. In this place they have earned the right to stand up and make their voices heard. In this place they are empowered and connected to both the land and to one another. Türangawaewae - a place to stand-embodies the fundamenta concept of our connection to place ("Papatūānuku the land"). The research site selected to explore this question is the urban area in and around Te Aro Pak in central Wellington which was once the site of Te Aro Pā. This site provides the thesis with a rich polyvalent layering of stories, interweaving landscape heritage, Māori heritage and colonial heritage within a single architectural conter This thesis is framed as an 'allegorica ( alambidou as a critical method for architectural esign research that is often characterised by speculative architectural drawing. The allegorica echitectural project integrates design and text to (tically reflect on architecture in relation to topics " "The Fall", 225).

The design-led research investigation explores how an allegorical architectural project can help to enable urban architecture to reawaken the transformative heritage stories that form place identity-utilising speculative architectural drawing as a fundamental tool for enabling architecture as well as it inhabitants to manifest a sense of belonging. The thesis proposes an allegorical architectural project as a research vehicle through which place identity can be challenged and fulfilled. By positioning an architectural intervention and its context within a dialectic confrontation, it examines how an allegorical architectural project can represent and communicate the temporal and multi-layere nature of place identity within a static architectural outcome.

By reconnecting architecture with site, and interpreting this connection allegorically within the design process, this thesis investigates how architecture can allegorically become the living inhabitant of a site, where the site itself gives architecture its tirrangwaewae, a place to stand. 
먼:믈 啉

PREFACE upon a path of self-discovery-a search for my own unique identity as an architectural designer in New Zealand.

Raised as a Pākehā in a 'westernised' household, my cultural identity was largely shaped by the family's Europen Māori ancestral links: however, the cultural ties of long since been lost. As a result the geneas had narrative that defined my own identity throughout my teenage years was missing significant elements. And it is only now that I have come to realise how much can be lost when significant heritage stories are forgotten. Compelled by a sense of culural estrangement I began to delve into my genealogical errative, with a focus on the Māori links the bad een lost. I discovered that despite my long-tem letachment, I till belong to and am affiliated with my iwi, Ngāti Ruanui.

As a young adult, this discovery transformed my As a young adul, his discovery trans an archecturat student, it also led me to questons regaring place identity in New Zealond and how here is a parallel theme to my own concealed heritse. These questions motivated ne to purse a research thesis investigating how architecture might a findament to comprehending a multi-layered narrative context.
The title of this investigation is the Māori word Tūrangawaewae, which means 'a place to stand"; it embodies the importance of place identity in he New Zealand context. The thesis argues that a place's heritage stories enable us to feel connected the land, making it our place in the world, our ome and our place to stand.

One of the most poignant stories I discovered in my . Te Aro Park and its adjacent toilet block, bus shelter and apartment blocks. These generic architectural constructs conceal the rich heritage stories of $T$ Aro Pā and the old Wellington waterfront - with small portion of the pā ruins displayed and protected under the Bellagio Ataahua apartment t 39 Taranaki Street. In a moment of profoun the this story was also linked to my own lost heritage. My iwi, Ngāti Ruanui, shared conctions with hrough Ngat Tup whe held joint ow Aro $\mathrm{Pa}$ of the pā in 1835 .

The loss of heritage recognition embodied by these buildings, and its parallels to my own identity crisis, me me ask myself: How might architecture help eveal these essential stories of place identity, while lo fillig the essential requirem . all to recognise the translation of 'place' into 'a place to stand'? 


\section{맨:목}

The mark of a good tutor is not to get cohorts of students to mimic their idols' tropes and miasmas. It is to help birth their worldview,

to help the new infant breathe and start to design with dexterity and an understanding of what might have gone before, but also with an imperative conditioned from an understanding of what might come after... In short, ... to lead the students to their own Elysian Fields.

\section{ACKNOWLEDGMENTS}

To Daniel Brown, my supervisor, my expositor, and my ceaseless supply of enthusiasm and fervour. His realms of te po has been paramount towards discovery of te ao märama.

To Karl who both inspired me to dream and then ensured that I saw those dreams through.

To Katie, for your love, faith and unwavering support.

To my family and loved ones, without whom this thesis could never have come to fruition.

To my Mother, who nurtured my dreams, ignited my passion and provided the vital support that was my passion and provided the vital support that was
needed to grow. I could never thank you enough. 


\section{AM / CODEX 01}

In the state of Te Kore, there existed unlimited potential for 'being'although it had no organised form. There was no gender, no male or female, yet all possibilities were contained within the confines of Te Kore. From Te Kore all things were
developed and created. Io (supreme god) formed and shaped every living thing from elements in Te Kore according to a pre-determined pattern.

\section{TE KORE | CHAOS \& POTENTIAL}

This thesis is structured as two bound volumes (codices) that represent a journey along an allegorical timeline, from one volume (codex) to the other. Codex 01, titled Te Kore | Chaos \& Potential, represents a journey that takes place during the hours of darkness, from midnight to the arrival of the rising sun. It contains all the design-led research and the design experiments that underpin the final outcomes. Codex 02 , titled Te Ao Mãram The World of Light, represents a journey that takes place during the hours of light from midday to the hour of the setting sun. It contains the developed design outcomes and critical reflection on the investigation as a whole. 
매:맨

CONTENTS

ए0: :0 AM / CODEX 01

Te Kore| Chaos \& Potential

모: 무

\section{Abstract}

Acknowledgments

마:

01 E Ngaro Ana I Te Pōuri|Lost In the Dark

1.1 Problem Statement
1.2 Research Proposition
1.3 Rear

1.2 Research Proposition
1.3 Research Question
1.4 Research Aim

1.5 Research Objectives
1.6 Method and Processes

1.7 Research Scope
1.8 Thesis Structure

02 Te Pō $\mid$ The Perpetual Night

Concept Design

2.1 Literature \& Project Review
2.2 Inception: Design Stage 01

모: 80

03 Haeata | Beam of Light, Sunrise

3.1 Literature \& Project Review
3.2 Contextual Analysis

07: 0404 Ngā Mihi O te Ra| Greeting of the Day Preliminary Design

4.1 Cognition: Design Stage 02
4.2 Activation: Design Stage 03

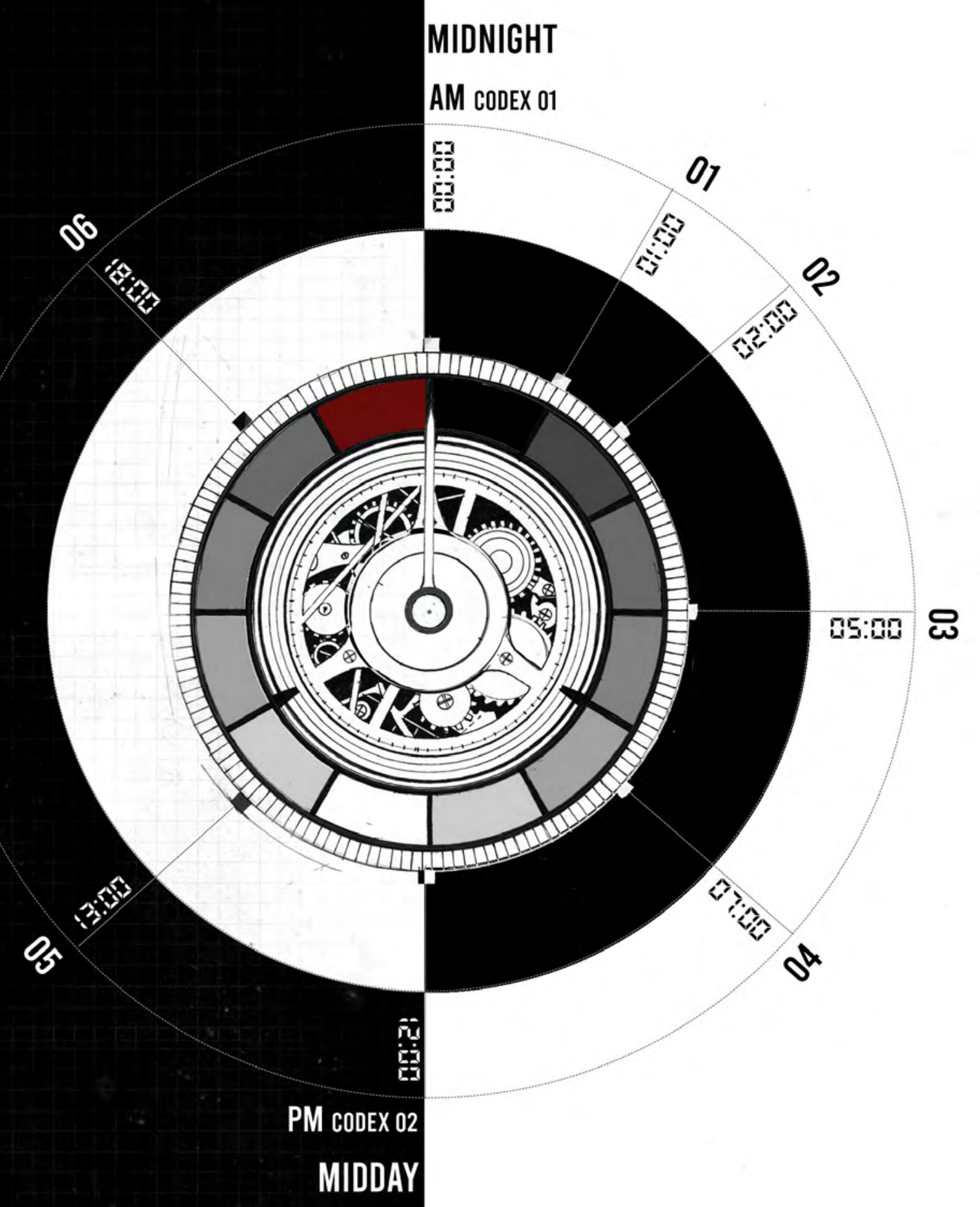

R: :0 PM / CODEX 02

Te AoMarama|TheWorddoflight

19: 05 Poutūmārō $\mid$ The Pinnacle, Midday Developed Design

5.1 Method \& Processs

5.2 Contextual Analysis

5.3 Literature and Project Review

5.5 Critical Reflections

19:06 Kokomea | Sunset Glow

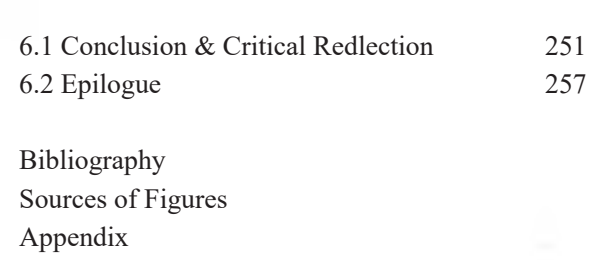


This edge of chaos, a scientific term for that slender territory between frozen predictability and hopeless disorder, is a dangerously unstable place. Learning and change can only happen there, but always under threat of sliding back to frozen order - or over into the chaotic abyss.

- Pamela McCorduck, The Edge of Chaos, nt

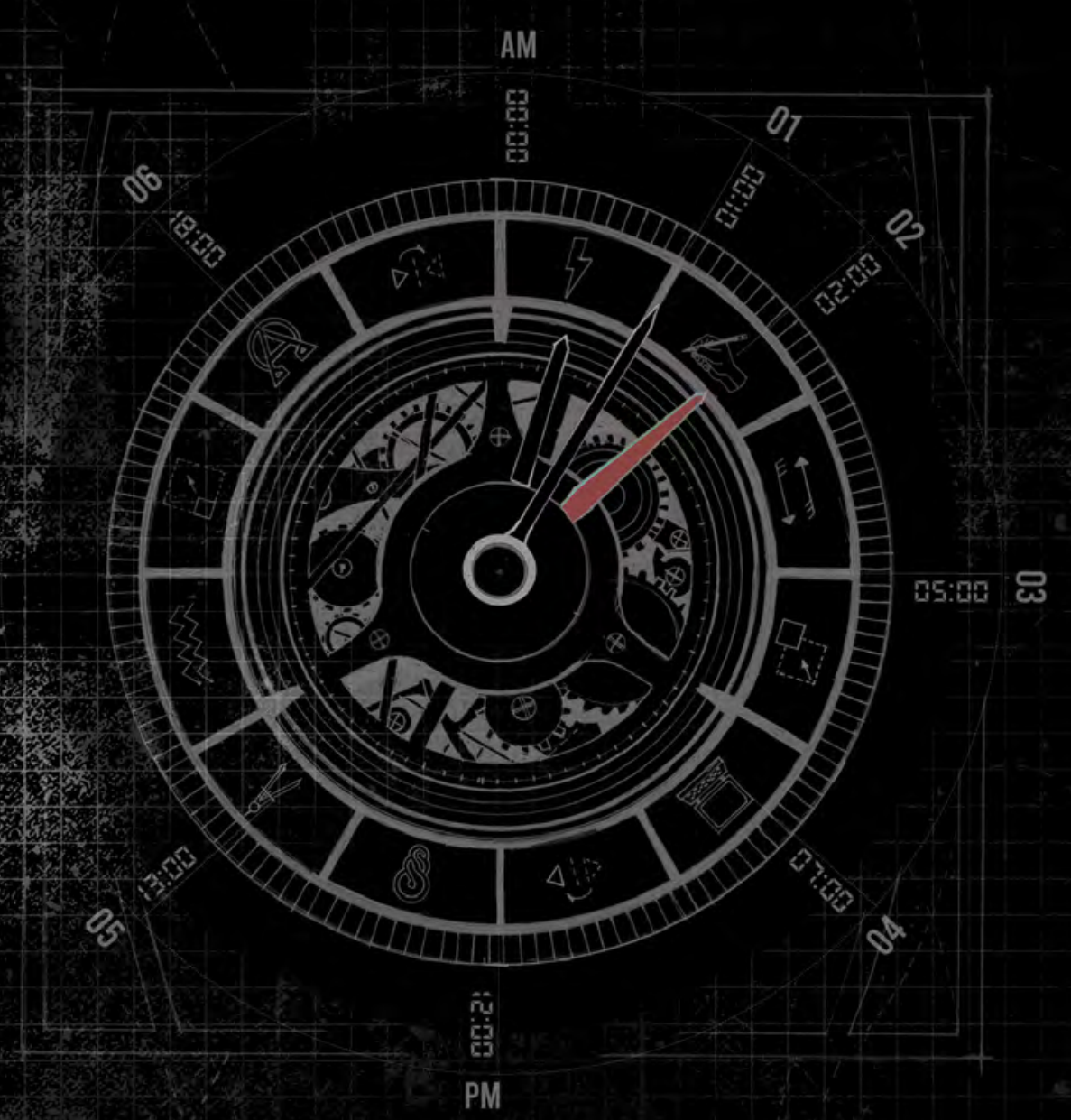

E NGARO ANA I TE PỐURI | LOST IN THE DARK INTRODUCTION 

always is found again.

This kind of structure is also contained in the world (otherwise we could not think it and apply it).

- Hans Dieter Schaal, Landscape as Inspiriation, p. 130.

CHAPTER 01 Chapter 01, "E Ngaro Ana I Te Pōuri | Lost in the Dark", introduces the Problem Statement, Research
Proposition and Research Question. It outlines the Research Aim and three principl Research Objectives. It describes the Method and Prearces, abd it articulates the Scope of the investigacesses, and it articulates the Scope of the investigation 
is typically conceived in ways that establish place identity relative to the contemporary context, often disregarding the plethora of heritage stories that define the transformative and shifting nature of place making. This thesis investigation argues that the landscapes beneath the surfaces of our cities are replete with heritage stories representing and intrinsically linked to the transformative evolution of the land, culture and society. The form of an urban building is usually designed to prioritise either its programme, brand identity, or a selected architectural style-often aesthetically and functionally alienated from the site beneath it. In this sense, the form of a building typically only engages place identity in relation to a current physical area-in most urban cases, a cleared site- becoming a temporal 'mask' that cone true place identity within it.

This design-led research investigation interrogates how urban architecture can be designed such that this functional and aesthetic identity of a building might still be recognised, while simultaneously re-connecting it with the transformative heritage stories associated with its context This investigation challenges architecture to equally prioritise the temporal place identity of the land upon which it stands. It positions site and architectural intervention into a dialectic confrontation acknowledges both contemporary deciso that determine a building's form, as well as the fundamental need for its inhabitants to understand and value this heritage context. 
We all know that telling stories is one of humanity's oldest pastimes. In architecture, Modernism put an end to story-telling unless it complied with the global meta-narrative, that of machine production is moral, clean, democratic and civilized' - the worst type of myth, if ever there was one.

- Niel Spiller, “Telling Stories", p. 128

\subsection{PROPOSITION}

around Phillip Pullman's fictional literary trilogy His Dark Materials, in which Pullman explores the provocative notion that the inner self - the "soul' - of a character can exist separately from the outer 'corporeal' self. Pullman's dialectic interrogates dialogue between the inner and the outer self as a means of revealing a deeper authenticity about he nature and identity of that character. Pullman's literary provocation will be used to investigate how tright be applied in this thesis to awaken the "soul' of a work of architecture-by safeguarding he transformative heritage stories that form place identity.

Dr Penelope Haralambidou, Associate Professor at the Bartlett School of Architecture in London, proposes that the Allegorical Architectural Project can be used as a critical method for extracting cont (Harab "The Fll"). This design-ed

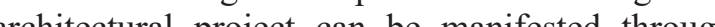
speculative architect cre drawings that are generated by Pullman's literary allegory. It draws upon a election of case studies taken from architecture from literature and contemporary Māori fine art.

Literary theorist Angus Fletcher argues that literary allegory occurs in two basic forms that he refers to as 'battle' and 'progress'. This design-led research thesis investigates how 'battle' and 'progress' can be applied to architectural interventions in relation to establishing an Allegorical Architectural Project. With a focus on engaging the heritage context of site within an allegorical architectural project, the thesis proposes that our understanding of place identity can be enhanced through the instigation of a symbolic allegorical 'battle', where site and architectural intervention are positioned as Due to the teries wing a dialectic narrative. Due to the terporal shifing nature of place identity the the interent undelying historical structure, of place proposes tha a tenporal understande mplication of Fletcher's symbolic allegorica 'progres' communicated through an architect raloutcome. 


\subsection{RESEARCH QUESTION}

This thesis asks:

How can urban architecture help to reawaken the transformative heritage stories that form place identity, enabling architecture as well as its inhabitants to have a place to stand türangawaewae?

\subsection{RESEARCH AIM}

To help address the Research Question, the principa Aim of this design-led research investigation is:

To explore how an allegorical architectural project can help to reawaken the transformative
heritage stories that form place identity heritage stories that form place identity enabling architecture as well as its inhabitan

\subsection{RESEARCH OBJECTIVES}

To help achieve the Research Aim, the three principal objectives of this design-led research investigation are:

\section{R01: ALLEGORY AS STORY-TELLING}

To explore how allegory can be applied to an architectural context to help translate heritage stories related to place identity into architectural

\section{RO2: ALLEGORY AS BATTLE / CONFRONTATION}

To explore how the representation of allegorical architecture as battle or confrontation can help establish contextual dialogues (spatial relationships) that help unveil the essential heritage stories relating to a site.

\section{R03: ALLEGORY AS PROGRESS / JOURNEY}

To explore how the representation of allegorical architecture as progress or journey can help establish temporal qualities (time-based heritage stories relating to a site. 


\section{PRINCIPAL THEORISTS FOR RO1}

Nothing is original. Steal from anywhere that resonates with inspiration or fuels your imagination. Devour old films, new films, music, books, paintings, photographs poems, dreams, random conversations, architecture, bridges, street signs, trees, clouds, bodies of water, light and shadows. Select only things to steal from that speak directly to your soul. If you do this, your work (and theft) will be authentic. Junenticity is invaluable, orginaly is non-existent. And don $t$ bother concealing our thievery-celebrate it if you feel like it...

\section{R01: ALLEGORY AS STORY-TELLING}

To explore how allegory can be applied to an architectural context to help translate heritage stories related to place identity into architectural form.

The principal theorists for addressing R01 are Angus. S Fletcher, who was a literary theoris and Distinguished Professor Emeritus at the City University; Penelope Haralambidou, Professo of Architecture and Spatial Culture at the Bartlet School of Architecture in London; and Neil Spiller, Hawksmoor Chair of Architecture and Landscape and Deputy Pro Vice-Chancellor at the University of Greenwich, London

Fletcher interrogates literary allegory, introducing and articulating both his definition of the 'daemonic agent' and his two primary categories of 'symbolic action' - progress and battle-which together form the foundation of literary allegory. Fletcher's theory is used to initiate a two-part framework for the thesis research investigatio where the allegorical project is manifested through a structured layering of theory, ideas and design. Haralambidou directly builds upon Fletcher's theory, interrogating allegory in relation to its application within an architectural project. She suggests a fundamental methodological approach for allegorical design-incorporating allegorical provocateurs and speculative drawing as primary methodological tools. Spiller critically reflects on the tool of speculative architectural drawing and its ability to invite the imagination to sponTāneously explore complex ideas in a visceral sense-while provoking critical reflection upon one's drawings, allowing for ideas to be re-read and re-interpreted, unleashing a cascade of architectural ideas. 
0 1:25 胹

\section{PRINCIPAL THEORISTS FOR RO2}

Differentiation invites confrontation in highlighting opposition In drawing distinction, conflict concedes to the slightest overlap. It is a moment of comparison that highlights the link as opposed to the rupture. Confrontation tapers choice towards selection. It is an acceptance of constraints, an attempt at resolution, towards precision

- Raimund Abraham

Martin Hogue

Catherine Hame

FINE ART CASE STUDIES

- Reply to Red, Yves Tanguy, 1943

Max Ernst, 1940

\section{RO2: ALLEGORY AS BATTLE / CONFRONTATION}

To explore how the representation of allegorical architecture as battle or confrontation can help establish contextual dialogues (spatial relationships) that help unveil the essential heritage stories relating to a site.

Attirement of the Bride

- The Soothsayer's Recompense, Giorgio de Chirico, 1913

- Near the Five Corners

Kay Sage, 1943

- The Poetry of America, Salvador Dalí, 1943

ARCHITECTURAL CASE STUDIES

- Enantiomorphistic Inversions,

Bryan Cantley, 2011

- Hostel,

Douglas Darden, 1993

- Entrance Situations in a Row,

Hans Deiter Schaal, 1970

Wall House 1,

John Hejduk, 1962

Higashi Asabu Building,

Morphosis, 1989

The principal theorists for addressing R02 are Austrian-American architect and educator Raimun Abraham; Martin Hogue, Associate Professor in the Department of Landscape Architecture at Cornell University; and Catherine Hamel, Associate Professor and Associate Dean of Architecture in the School of Architecture, Planning and Landscape at the University of Calgary

Abraham critically reflects on established confrontations inherent within architectural conception, a necessary link relating Fletcher's allegorical 'battle' to confrontations within the realm of architecture. Hogue contends that site and project can be understood as dual elements of dialectic, inciting an architectural narrative that reenergises and responds to the relationship one shares with the other. Hamel reflects on the manifestation of confrontation in drawing - providing examples of how an opposition of site and project might be understood through graphical representation. 
Allowing for leaps and breaks in the space-time continum, the effects of ime in cinema are not merely manifested... Time itself becomes visible. We observe not history already remade but history in the very process of it remaking

- Christina Lee, Violating Time, p. 02.
R03: ALLEGORY AS PROGRESS / JOURNEY

To explore how the representation of allegorical architecture as progress or journey can help establish temporal qualities (time-based relationships) that help uies the

The principal theorists for addressing $\mathrm{R} 03$ are Soviet film director and theorist, and pioneer in the theory and practice of montage, Sergei Eisenstein Carol J. Burns, FAIA, educator and principal with Taylor \& Burns Architects; and Bryan Cantley, Form:uLA Founder/Owner and Professor of Design Theory at CSUF.

Eisenstein critically reflects on the similarities between filmic montage and architecture, suggesting two primary ways that architecture can engage the temporal. Burns critically reflects on the embodiment of time and heritage in relation to place identity-proposing a means through which the architectural intervention might reflect a temporal understanding of site. Cantley introduces and discusses his 'Taxonometric Drawing' approach, a speculative architectural drawing method that simultaneously engages three conditions of notation, forming a drawing that complexly annotates itself as part of its own presentation. Cantley's methodological design approach will be tested throughout the preliminary and developed design stages of the thesis.

- Rākau whakapap

(Māori Mnemonic Staff)

ALLEORICAL PROVOCATEUR: MAORI FINE ART

Middle North Shane Cotton, 1997

Architectural Case Studies

- Surface Topology ExperimentForm:uLA,

Bryan Cantley, 2010 
Start by looking at the picture, running information on a surface, go behind the picture fall down in the landscape, study the assemblege, piding up ches placed scatiered th time, turn and look towards the door, and build the link back to the top.

\subsection{METHOD AND PROCESSES}

$\mathrm{T} \quad \mathrm{h} \quad \mathrm{e}$ strengths and weakness in addressing the Research research Question

This allegorical architectural investigation is initially framed around the literary allegory of the dæmon in Philip Pullman's fantasy trilogy His Dark Materials. In the first phase of the investigation, Surrealist paintings and speculative architectural drawings are interrogated as design-based case studies that exemplify Battle and Progress-Angus Fletcher's two principal characteristics of allegory. Paintings by contemporary Māori artist Shan Cotton are interrogated throughout as design-based case studies that exemplify Battle and Progres and Culmination. Inception, Cognition each of the three Research Objectives and the final stage integrates them together as the design outcome. Each stage applies provocations and delivery methods, the iterative research outcomes representing opportunities to test architectural project. Each of these stages iteratively develops on the through a different point of view. In the second phase architectural drawing _ as the design methods and Mnemonic Staff) isintroduced as a primary symbolic research experiments transition back and forth allegorical provocation exemplifying Progress in between the sketchbook, drawing board and into relation to establishing and safeguarding identity. the digital realm. Drawing from Peter Downton's Throughout the investigation, the learnings from 2013 book Design Research the thesis employs the these case studies and related theoretical writings med " "research by design" (Downton). Using are translated into architectural responses that seck his apprach, design experiments are developed throughout the thesis to fuel ideas and drive the research investigation. As the research iteratively evolves, it is critically assessed in relation to

are translated into architectural responses that seek that define the research site, providing - through architecture — a place to stand | tūrangawaewae. 
When you choose one way out of many, all the ways you don't take are snuffed out like candles, as if they'd never existed.

At that moment all Will's choices existed at once. But to keep them all in existence meant doing nothing. He had to choose, after all.

- Philip Pullman, His Dark Materials, p. 45
1.7 SCOPE This design-led research investigation is situated as Speculative Architecture. differs from 'ordinary architecture' in that it is paper-based and not meant to necessarily be built. As speculative drawings, it typically uses 'storytelling' in establishing a discourse about the future of our urban realms (Young).

As a speculative architectural project, this thesis As a sigation employs allegory as a thesis method for design. It builds upon Haralambidou's interpretation of the allegorical architectural project (Haralambidou "The Fall", 123), which focuses (The articulated through the combined application of drawing and text.

The research draws from case studies both inside

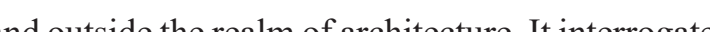
section of precedents that evidence inheren prositions situting allegorical links between them, the cateris the diverse approbes into layered framework. This provides a rich, complex, et praticable foundation for the design reser.
As such, the physical limitations, construction costs and technical engineering requirements are al outside the scope of this investigation. The scope of n is restricted to one relevan ction of one urban site, Te Aro Park.

The most important limitation to the scope of this investigation is the enormous amount of heritage information that has been permanently lost and will never be recovered. A few foundations from the original Te Aro Pà remain, but little else; even he streams have been culverted. While a sense of the heritage stories can be garnered from historic photographs and archival records many of the most vibrant stories associated with this place will never be known. I was fortunate, as port of my rits to be taken behind the scenes of the $p \bar{a}$, by an iw

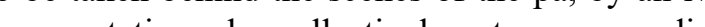
of this place. While this is a acred a plardian photography was not an opton, secing the remain from this perspective and witnessing the $\bar{p}$ ruins in person was an extremely moving experience for as I relised the sheer weight of the nernetive these 
01:45 $\mathrm{Am}$

\subsection{THESIS STRUCTURE}

\section{1}

Q1:

E NGARO ANA I TE PŌURI | LOST IN THE DARK

INTRODUCTION Chapter 01 introduces the Problem Statement, Research Proposition and Research Question. It outlines the Aim and three principal Research Objectives; articulates the Scope of the investigation and the Thesis Structure.

\section{2}

말ㄹ:맵

\section{TE PŌ | THE PERPETUAL NIGHT}

LITERATURE + PROJECT REVIEW Chapter 02
INGEPTION

begins by foundation and architectural applicationarticulating the ambiguous nature of allegorical narrative in order to elucidate it within a concise framework for research. It identifies the principal allegorical literary provocation and a series of allegorical speculative architectural drawing case studies relevant to Research Objective 01. These provocations are translated through a series of conceptual speculative sketch experiments. These conceptual design experiments form Inception: the conceptual foundation of the allegorical project:

\section{3}

모: 매

\section{HAEATA | BEAMOF LIGHT,SUNRISE}

LITERATURE \& PROJECT REVIEW

Chapt theorists and inferrogates a series of allegorical fine art provocations and architectural case studies in relation to Research Objective 02-instigating a confrontation between architectural intervention through the manifestation of Fletcher's symbolic action 'battle. It includes a contextual site analysis in relation to the inherent confrontations and explores dialectic opportunities. This chapte forms the Literature and Project Review and the Contextual Analysis for Design Stages 02 and 03 Preliminary Design.
CODEX 01

AM 00:00

TE KORE I CHAOS \& POTENTIAL

The thesis timeline structure was inspired from a Māori creation myth, which begins with $\mathrm{Te}$ Kore, chaos \& potential—also known as Te Pō, the perpetual night. From this darkness emerged Ranginui, the sky father and Papatūānuku, the earth mother, who were separated by their children in order to reveal, Te Ao Mārama, the world of light (Charles Royal, np). The chapter titles establish a metaphorical framework moving from the realm of darkness and unlimited potential at midnight, AM (Codex 01), into the world of light, in midday, PM (Codex 02). This first Codex functions as a transitional journey through the allegorical architectural project, it consists of four chapters as follows.

\section{4}

막:매교

\section{NGÄ MIHIOTE RA | GREETINGOFTHEDAY}

COGNITION + ACTIVATION Chapter 04 applies case studies from Chapter 03 in reorists and Research Objective 03-representing temporal understanding of site through the manifestation of Fletcher's second symbolic allegorical action 'progress'. The preliminary design research outcomes for this chapter are divided in relation to the two differing contextual issues they address. These form both Cognition and Activation Design Stages 02 and 03. Design Stage 02, Cognition, involves the design of a public toilet block, while Design Stage 03, Activation, becomes the design of a bus stop facility. 


\section{CODEX 02}

PM 12:00

TE AO MĀRAMA | THE WORLD OF LIGHT

Moving into the world of light, PM (Codex 02) functions as a holistic journey through the entirety of the allegorical project from Inception to Reflection. In this codex, methods and processes from Codex 01 are revised and refined in relation to the developed design of an apartment complex at 39 Taranaki Street. The codex takes the form of a curated journey through the entirety of the allegorical architectural project-revisiting provocations and theories from Codex 01 and reintegrating them through the perspective of Tikang Maari. Codex 02 forms Culmination, Design Stag 04 , transitioning through all three allegorical design stages of Inception, Cognition and Activation. I becomes the conclusion and critical reflection as well as a final epilogue that provides a suggestion for future research opportunities.

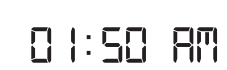

\subsection{THESIS STRUCTURE}

05

回:吅

POUTŪMĀRŌ - MIDDAY, THE PINNACLE

\section{CULMINATION}

Chapter 05 presents the Developed Design research outcome. The chapter forms Culmination: Design Stage 04-becoming the developed design proposition for a multi-story apartment building. The final design integrates the learnings from the previous designs within a singular scheme that represents the architectural realisation of Tūrangawaewae.
06

凅: 믄

\section{KOKOMEA - SUNSET GLOW}

CONCLUSION Chapter 06 reflects critically in relation to both the Research Aim and the three principal Research Objectives. It discusses why this has been an important issue to resolve through design; how effective the methodology has been in achieving the design outcome; how successful the experiential nature of the outcome has been in addressing the Research Question; the conclusions that can be drawn from the investigation; the constraints and limitations of the original scope; and how the findings might be applied or advanced in future, if extended beyon this scope 


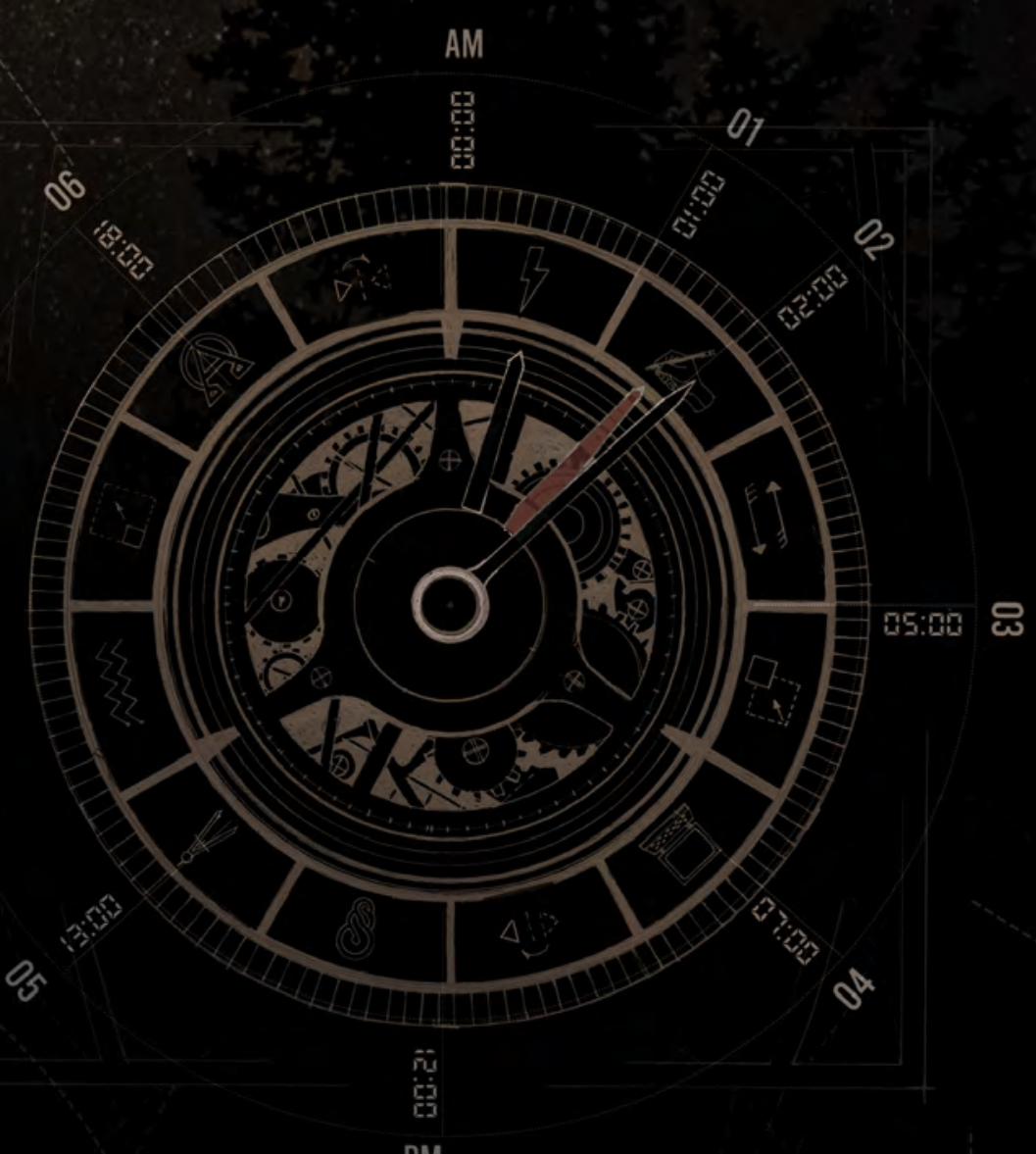

From the empty void comes the realm of Te Pō-the perpetual night. In Te Pō, long olitary periods are flooded in shades of darkness. Te Po (the dark night); Te Pónui (the great night); Te Pó-roa (the long night); Te Pō-uriuri (the deep night); Te Pó-tangotango (the intensely dark night). These are the names of a place where no light exists. But within this darkness come moments of movement - the consciou. stirring of being, the beginnings of a change towards the realm of becoming.

- Maureen Lander, $n p$.

PM

TE PŌ | THE PERPETUAL NIGHT INCEPTION 


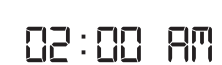

\section{s.}

$$
\text { - John Miton Pardise Lost In. } 81-85
$$

CHAPTER 02 Chapter 02, “Te Pō The Perpetual Night", Literature and Project Review for Design Stage 01, and the second section, titled "Inception", represents the Concept Design Stage (Design Stage 01: Inception) of the thesis investigation. The goal of Chapter 02 is to address the first principal research objective R01:

To explore how allegory can be applied to an architectural context to help translate heritage stories related to place identity into architectural form.

This chapter outlines the theoretical bases underpinning the allegorical architectura project and reflects on its application within this project and reflects on its ation wis provocations, and case studies in relation to Research Objective 01. The chapter begins by investigating allegory in relation to its literary foundation and then reflects on its architectural application. A principal literary provocation is identified and interpreted in relation to both allegory and its applicability for addressing the

A related Māori fine art provocation is also identified; together these are ex to establishing an allegorical narrative. With the added implementation of specultive drawn theory, these initial provocations are taws hrough a series of speculative sketches that

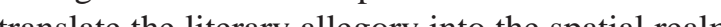
of the architectural project. Thes initiat concept design resch oul "Incepion; Design Stage 01" - foudtion " Stage 01 - he fould 
2.1.1 LITERARY ALLEGORY According to literary theorist Angus J. S. Fletcher, allegory is a form of narrative, which, in its
simplest terms, says one thing and means another. It destroys normal expectations of language through a fundamental process of encoding speech. Fletcher argues that due to its linguistic nature, allegory has appeared in countless forms in various works (Fletcher 1964, 2-5).

The whole point of allegory is that it does not need to be read exegetically; it often has a literal level that makes good enough sense all by itself. But somehow this literal surface suggests a peculiar doubleness of intention, and Whe it can, as it were, get along without interpretation, it becomes much richer and more interesting if given interpretation.

- Angus J. S. Fletcher, Allegory: The Theory of a Symbolic Mode, p. 77.

Let us for reference purposes consider a rough rhetorical definition: allegory is a method of double meanings that organizes utterance (in any medium) according to its expression of analogical parallels between different networks of iconic likeness.

- Angus Fletcher, “Allegory Without Ideas", p.78

Literary critic John MacQueen, in his book Allegory, outlines a historical overview for literary allegory, suggesting that with its philosophica and theological origins, allegory is intrinsic within traditional narratives in the form of myth. MacQueen recognises Plato as the founder of many aspects of allegorical thinking, with other majo early examples appearing throughout both the $\mathrm{Ol}$ and New Testaments (MacQueen, 10).

In his book Allegory; The Theory of a Symbolic Mode, Fletcher argues that every literary allegory contains a Daemonic Agent (which represents the fundamental force in an allegory) and Symbolic Action (which represents the outcome of that force). Symbolic Action has two key attributes tha 'oter' th as Batle (a type of confrontation with (a type of journey that is undertan Progress (avolution). 
The key to understanding how allegory works is to focus on its mode of agency, and here we find that from ancient times to the present, under varying guises, the demonic-not necessarily bad-is the embodiment of primordial agency; the daimons of Greek myth have a unique power to act without impediment, obeying a system of absolute, single-minded, purified intention.

\subsubsection{DAEMONIC AGENTS}

A c cording to Fletcher, literary allegory can be articulated as the (protagonists) with corresponding actions and (promenists) wh sor cons and ctions of the mind

Fletcher defines these allegorical 'agents' as the 'daemonic agent', drawing from the Greek and Hebrew definition of 'daemons'- which, unlike its present understanding as a diabolic creature, is thought to exist in all intermediate stages of good and evil. A particularly celebrated example of this notion is Socrates's 'daimon', the voice that he believed both informed him of the right path and enforced virtue upon him (Fletcher 1964, 40-44).

Fletcher suggests that all allegorical protagonists must evidence this daemonic agent, usually taking the form of an internal governing force which, through interpretation, reveals critical insight into allegorical meaning and its inherent intention. A daemonic agent is often invisible, manifested within the actions of the protagonist, dictating and personifying allegorical meaning through its interconnected relationship between both the superficial narrative and underlying allegorical intention. The daemonic agent could be identified as the convergence point of dual meanings, $1964,40)$ 


\subsubsection{SYMBOLIC ACTION}

Fletcher, in order discern the symbolic action(s) at play. Fletcher argues that all allegorical narratives evidence either or both of two fundamental patterns of symbolic action. As both categories often merge, it is necessary to differentiate between the allegorical effects and themes of each.

and they do not meregries 0 resolve themselves into either of two basic forms, returning to insist upon them. The two may be labeled as 'battle' and 'progress'.

-Angus J. S. Fletcher, “Allegory Without Ideas", p. 78.

BATTLE In its most common sense, 'battle' is enacted through an actual violence, where opposing forces represent a conflict of ideas and ideals. However, battle can be defined in a broader sense, as a balanced conflict caught within a given moment in time. Fletcher suggests that these "conflicts can be symmetrically duplicated and repeated within a work. As one side takes a swipe, so the other side takes one” (Fletcher 1964, 159). In the case of the battle, allegorical interpretation of symmetry and balance. The battle could be considered as the symmetrical presentation of two arguments, forces or ideas, where both are given equal priority within the holistic narrative kind of debate, which through inequalities and irregularities within the symmetrical confrontation, begins to reveal the underlying allegorical intention being communicated (Fletcher 1964, 158).

PROGRESS Unlike battle, progress is a product of the temporal, as it is insically attached to an evolving sequence of takes the form of a material description of travel, represented by voyages, journeys and pilgrimages. In other forms, the allegorical progress might appear as an introspective journey through the self, or through a catalogue of objects recalled to min emporally without any physical displacement occurring. Fletcher suggests that progress ultimately differentiates itself from battle through its embodiment of the 'ritual'- a sequence of steps or actions in one main direction or prescribed order. In this sense, Fletcher is associating ritud with a temporal series of events, where allegorical interpretation exists within the progression, exaggeration and equality of each 'ritual' step. The reader must enact each step of this journey hrough reading or viewing in order to decipher the underlying allegorical narrative (Fletcher 1964, 153-155). 
2.1.4 ALLEGORICAL TRAITS Fletcher proposes that in literary allegory, 'Symbolic Action' is often manifested ( Visual vs. Verbal, Duplicity of Meaning, and Incomplete Fragmented. Architectural theoris Penelope Haralambidou, in her article "The Fall: The Allegorical Architectural Project as a Critical Method", proposes that these four attributes can be applied to an allegorical architectura outcome through drawing. Haralambidou outlines a theoretical framework for the allegorica architecture project, in which she describes how Fletcher's literary allegorical traits can be applied within the allegorical architectural project.

\section{FIGURATIVE}

GEOMETRY Fletcher describes one key trait of allegory as a figurative geometry (Fletcher 1964, 4), suggesting allegorical narratives (Fin geometric principle. Abstract numbers and letters ere replaced with personages, everyday/subles abjects and sites to signify an underlying strublume relationship.

Drawing from Fletcher, Haralambidou argues that in the allegorical architectural project, figurative geometry appears though sy symmetries, These inform multiple layers of spanties. these underlying structur of thougt (H “The Fall”, 227).

\section{VISUAL VS.}

VERBAL In Fletcher's description of allegory in literature, text is used to conjure a visual image. In Haralambidou's description of the allegorical architectural project, drawing and text are combined in the production of meaning. She refers to the incorporation of drawing and text
as the Visual vs. Verbal. A reciprocity between the as the Visual vs. Verbal. A reciprocity between the visual and verbal occurs where words are treated as be deciphered.

Allegorical architectural projects tend to blur the boundaries of design and research, where research is not a separate element accompanied by text but rather a drawing-based technique that text, but texts. Through Haralambidou's an notes, drawing and diagrams are combined to bring towner ideas, shifting between writing to dring and synthetic. (Haralambidou "The Fall", 234).

\section{DUPLICITY OF}

MEANING According to Fletcher, all allegories evidence a duplicity of meaning, derived through the principle of saying one thing and meaning another. However, often the link between what is articulated versus what is interpreted tends to differ. Here exists a blurred for critcal interpretation by the viewer/reader for critcal imearthing the author. In this instance, an allegorical work is considered most successful when it triggers multiple interpretations, as at this point, the creative act extends beyond the artist, where the viewer is invited to make their own contribution to the works.

Haralambidou suggests an important link, that the drawing is for architecture what language is for literature, where the difficulty of interrogating the substructure of architectural thinking is easier to deal with through a metaphor or an allegorical narrative (Haralambidou, “The Fall”, 231).

\section{INCOMPLETE}

FRAGMENTED According to Fletcher, another trait of allegory is to be left unfinished. Fletcher suggests that this unfinished and fragmented nature of allegory needs to be considered in a dynamic context, as all anate are both incomplete and in-completable, and llegory simply records this anche narrative form (Fletcher 1964, 174).

Haralambidou argues that allegorical architectural are by definition, are uninished since they are never built. When writing about he own allegorical architectural project The Fall she argues that the project exists in the form of sketches and notes where the sketchbook is not just a representation of the project, but rather site and the medium through which it developed (Haralambidou, "The Fall", 231). As a result, the allegory may appear fragmented and unfinished where the fragmentation in the sketchbook can be reinterpreted and translated metamorphising into a 
Often the allegorical architectural project refers to another piece of work or site. The allegorical interpretation reveals an analytical inclination and the project becomes a vehicle for criticism. Allegorical design, therefore, is a critical method, which distances the architect from the construction ste and redefnes her as a commentator of spatial phenomena better grasped and analyzed through drawing and text.

- Penelope Haralambidou, “The Allegorical Project: Architecture as Figurative Theory”, p. 118

\subsubsection{ARCHITECTURAL ALLEGORY}

CASE STUDY

In her article "The Fall; The Allegorical Architectural Project as a Critical Method", Haralambido itself a critical method, distancing itself from buit examples of allegical actitecture choosing to focus on the realm of the imagined, where speculative drawing is seen as a primary mode to interpret and design allegorical architecture (Haralambidou, "The Fall”, 225).

The allegorical architectural project, although at times visually and physically inhabited, is often disconnected from the material construction of a building. The imaginative, sometimes poetic bringing together of ideas positions it closer to visual literature and, because of its high dependency on narrative, it can be a bridge between a work of art, painting or sculpture, and a literary text, poem or novel.

enelope Haralambidou, "The Fall; The Allegoric Architectural Project as a Critical Method", p. 225

This section explores Haralambidou's proposition of allegory as a critical method for architectura design. It interrogates her 2004 project The Fall, The Design of an Imaginary Building. It then an allegorical a che address the unique issur pertaining to be used to 
THE FALL In the allegorical architectural case the nude figure Lisa, suggests thar the fenale figure sits on the

Additionally, the allegorical architectural project can be employed to unravel another piece of work, a site or drawing itself by questioning its and becomes a vehicle for criticism.

- Penelope Haralambidou, “The Fall: The Allegorical project as a critical method" p. 225 study The Fall, Haralambido combines two works of art, Leonardo da Vinci's
Mona Lisa (1503-7) and Marcel Duchamp's Mona Lisa (1503-7) and Marcel Duchamp's assemblage given: $1^{\circ}$ the waterfall, $2^{\circ}$ the illuminating gas (1946-66), where she interprets

In my project, the two enigmatic figures merge, condemned to share the same lost identity. Lady on a Balcony, a less-known tille for Mona mysterious landscape. In The Given, the femate ude observed through the door of a backard lies submerged in a similar landscape. In the project, the two locations converge at the waterfall on the right side of both images. What we see is the same landscape from two different viewpoints; the change of position, The Fall which also causes the undressing of the woman, results from her fall from the balcony to the backyard.

Penelope Haralambidou, “The Fall; The Allegorical
Architectural Project as a Critical Method”, p. 225.

Duchamp's view from the backyard. The female character becomes Fletcher's 'daemonic agent' of The Fall, falling from the balcony into the garden, returning hrough the conidor to the tower and back to the balcony, only to fall again in a repeated cycle (Haralambidou, 228). In terms of allegory, the project suggests an architectural and spatial relationship for the figure in Duchamp's Given, whom Haralambidou sees as the result of Mona Lisa's fall from the balcony. During the fal Mona Lisa undergoes transformation, losing her clothes and transitioning from the two-dimensiona portrait into the three-dimensional landscape. Haralambidou describes The Fall as a projec aimed to critically analyse Duchamp's allegorical work, which in its own nature becomes an allegory itself. In the following analysis of allegorical traits, Haralambidou draws links between Given and The Fall, reffecting on its function as a critical method by examining key allegorical traits from both literature and fine art.

This content is unavailable.

Penelope Haralambidou, The Fall, sketchbook, 2004

Penelope Haralambidou, The Fall, sketchbook, 2004,
in "The Fall: The Allegorical Architectural Project as Critic
Print.

According to Haralambidou, the architectura void hidden behind Mona Lisa's visual shadow in Leonardo's portrait. It is comprised of a towe supporting the balcony where she sits, joined to a long corridor that traverses the void, leading to 
02.1.6 ALLEGORICAL

\section{ARCHITECTURAL}

\section{FRAMEWORK}

Fletcher and Haralambidou, th
thesis proposes to legorical architecturap a framework for its ow key allegorical work of fiction (Philip Pullman's is Dark Materials), speculative drawings by of fine art both European Surrealist paintings and contemporary New Zealand paintings by Māori artist Shane Cotton that represent similn allegorical objectives to the thesis proposition.

The design-led thesis investigation builds upon these allegorical exemplars, using them as 'generators' or 'provocations' to establish a project, which will use speculative architectural drawing as the principal approach to convey the research ourcomes. The research begins in the sketch book (Conceptual Design), then moves an urban area in Wellington (Te Aro Park for the Preliminary Design experiments), and finally to a discrete urban ste in Wellington (75 Taranak Street for the Developed Design outcomes). A framework is devised where each of the four key allegorical traits appears in the research through the

\section{FIGURATIVE GEOMETRY}

Figurative geometry is established through a layering of provocations, where each stage
evidences an ongoing development of figurative elements.

VISUAL VS. VERBAL

Each stage must evidence both visual and verbal with critical interpretation, instigating a plethor of underlying meanings.

\section{DUPLICITY OF MEANING}

Following the conclusion of each stage, outcomes meaning and other unintended interpretations.

\section{INCOMPLETE FRAGMENTS}

Each stage must evidence the notion of the rransitions to 'fragmentation' as the design progresses towards a developed solution.
믈: 35 唡

\begin{tabular}{|c|c|c|c|c|}
\hline & $\begin{array}{l}\text { Design Stage } 01 \text { (Concept Design) } \\
\text { INCEPTION } \\
0\end{array}$ & $\begin{array}{l}\text { Design Stage 02 (Preliminary Design) } \\
\text { CONCEPTION } \\
\text { O_- _- _- _- }\end{array}$ & 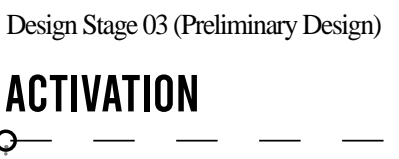 & $\begin{array}{l}\text { Design Stage 04(Developed Design) } \\
\text { CULMINATION } \\
\text { O__ _ _ _ }\end{array}$ \\
\hline $\begin{array}{l}\text { RESEARCH } \\
\text { OBJECTIVE }\end{array}$ & R01 & R02 & R03 & FINAL OUTCOMES \\
\hline PROVOCATION(S) & $\begin{array}{l}\text { Literary - Pullman } \\
\text { Fine Art - Cotton } 01\end{array}$ & $\begin{array}{l}\text { Literary - Pullman } \\
\text { Fine Art - Surrealism } \\
\text { Speculative Architectrure }\end{array}$ & $\begin{array}{l}\text { Literary - Tikanga Māori } \\
\text { - Pullman } \\
\text { Fine Art - Cotton } 02\end{array}$ & $\begin{array}{l}\text { Fine Art - Cotton 03 } \\
\text { Speculative Architecture }\end{array}$ \\
\hline SYMBOLIC ACTION & Allegory & Battle & Progress & Combined \\
\hline DAEMONIC AGENT & $\begin{array}{l}\text { Architecture's daemon } \\
\text { 'soul' }\end{array}$ & $\begin{array}{l}\text { Architecture's daemon 'soul' } \\
\text { as heritage layers }\end{array}$ & $\begin{array}{l}\text { Architecture's daemon 'soul' } \\
\text { as temporal 'place identity' }\end{array}$ & $\begin{array}{l}\text { Architecture's 'soul' as } \\
\text { reconnection to site and } \\
\text { temporal place identity }\end{array}$ \\
\hline DRAWING STYLE & Freehand Sketch & Digital Sketch & Digital Sketch & $\begin{array}{l}\text { Free Hand } \\
\text { Digital Sketch }\end{array}$ \\
\hline $\begin{array}{l}\text { CONTEXTUAL } \\
\text { CONFRONTATION }\end{array}$ & $\begin{array}{l}\text { Sketch Book } \\
\text { Real vs. Imagined }\end{array}$ & $\begin{array}{l}\text { Siti } 01 \text { Te Aro Park } \\
\text { Sacred vs. Profane }\end{array}$ & $\begin{array}{l}\text { Site } 02 \text { Te Aro Park } \\
\text { Natural vs. Constructed }\end{array}$ & $\begin{array}{l}\text { Site } 0339 \text { Taranaki Street } \\
\text { Cumulative Confrontations }\end{array}$ \\
\hline
\end{tabular}


A film, artwork or text is not necessarily architecture but it can, at the very least, be architectural in specific ways, whether spatial, material or temporal, especially if it is considered as a series of strategies, elements and techniques rather than an indivisible whole. This suggests that anyone wanting to produce architecture should, frist, discard the preconceived boundaries of the disciplite and, second, be prepared to learn from architecture wherever it is found, whoever it is produced by

\footnotetext{
- Jonathan Hill, “An Other architect", Occupying Architecture: Between the Architect and User. p. 139.
}

\subsubsection{LITERARY PROVOCATION}

PHILIP PULLMAN

HIS DARK MATERIALS

In order to frame the allegorical

architectural project to address the thesis's Research Question, a relevant literary provocation an allegorical design generator, which will be used to instigate and fuel the initial allegorical narrative.

In relation to both its embodiment of Fletcher's 'daemonic agent 'and its relevance to the Research Question, Philip Pullman's fictional trilogy His Dark Materials was selected as a provocation for framing the allegorical architectural project. Pullman's title is taken from Book II line 96 of materials refers to the mixture of water, earth, air and fire involved in the creation of the world (Tucker, 152). In an interview, Pullman described his work, as somewhat of a retelling of Milton's famous poem.
So, it was the landscape, the atmosphere that was my starting point. But as the narrative began to form itself on the page, I found that - perhaps drawn by the gravitational attraction of a much greater mass - I was beginning to tell the same story, too.

$$
\text { — Philip Pullman. “Introduction to Paradise Lost”, np. }
$$

It is through this context, derived from a retelling of Paradise Lost, that Pullman's trilogy establishes its fundamental allegorical lesson. As an allegorical architectural project, this design-led thesis investigation aims to also convey a lesson through the formation of an allegorical agenda. The thesis investigation's allegorical agenda is focused on the reconnection of architecture with its contextual heritage. For the thesis's allegorical outcome, two primary ideas are adopted from Pullman's literary allegory, including the 'alethiometer' and the 'dæmon'. 


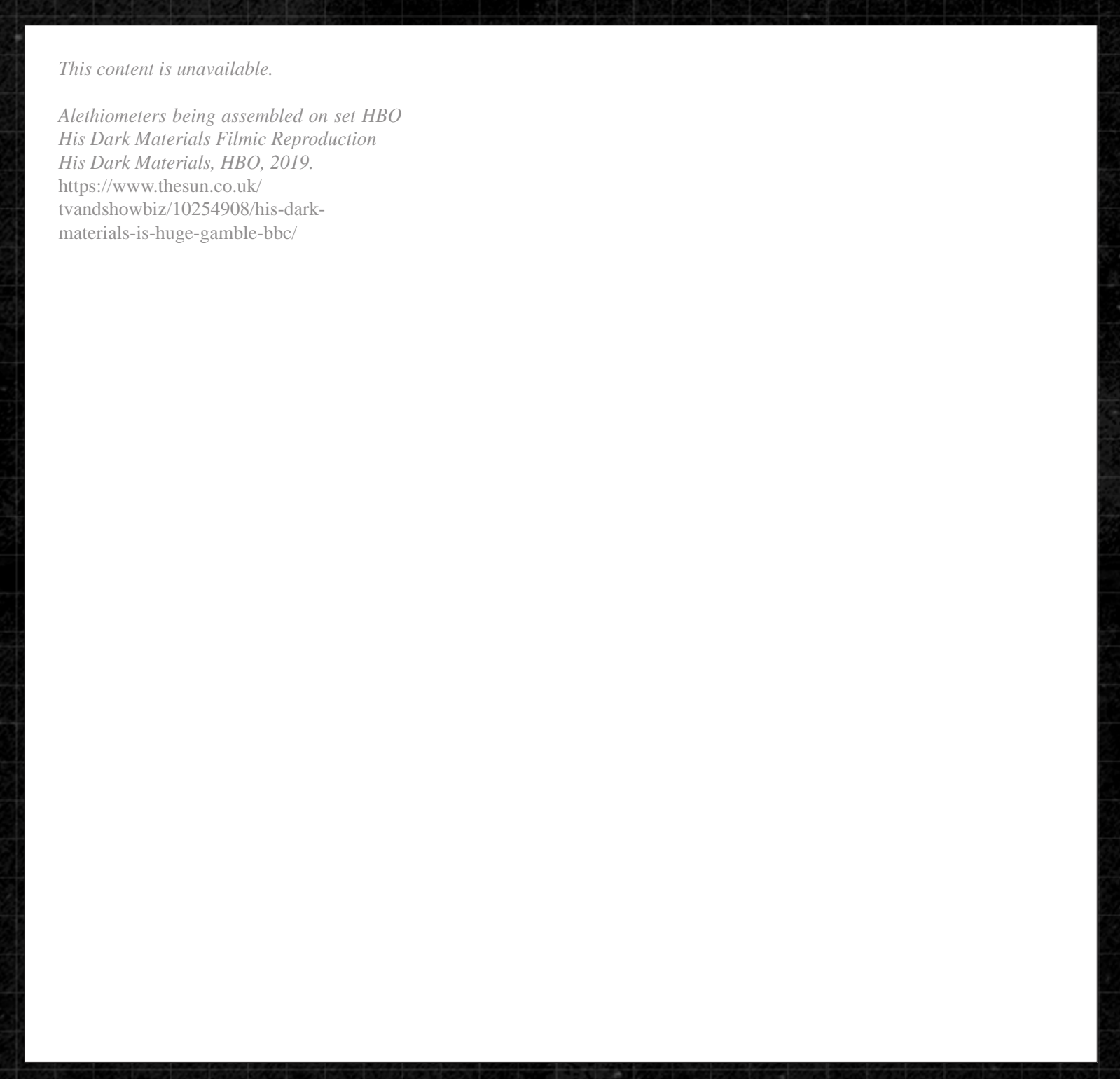

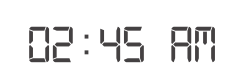

GS

THE ALETHIOMETER In book one of the trilogy His Dark Materials, called Northern lights, Pullman introduces a device called the 'alethiometer', 'meter' which translates as 'truth measure'. The alethiometer is a tool used by protasonist Lyra Belacqua to discern the truth and also the direction she must take in order to fulfill her destiny (Greenwell, 104).

It lay heavily in her hands, the crystal face gleaming, the brass body exquisitely machined. It was very like a clock, or a compass, for there were hands pointing to places around the dial, but instead of hours or the points of the compass there were several little pictures.

$$
\text { - Philip Pullman, Northern Lights, p. } 71 .
$$

Pullman's alethiometer is reimagined as a symbolic tool for the thesis; functioning as both a timekeeper and compass, it maps each stage of the thesis and assembles chapters in relation to an iterative sequential allegorical 'progress'. In this with Fletcher's alenimeter can be associated whe the als to the temporal position within the research process. The three hads of the aldioneter process. The thee hands of the alethiometer

When he unfolded the cloth, Lyra saw something like a large watch or a small clock: a thick disk of gold and crystal. It might have been a compass or to read it, you'll have to learn by yourself.
Figure 2.03. Alethiometers being
ssembled on set of HBO His Dark Materials filmic reproduction 
Pullman, in short, seems to be using daemons as

something akin to individuals' souls... People without

dcemons may be able to survive, but theirs is a subhuma

existence without meaning or purpose: a soulless life.

- Freitas, Donna and Jason King, Killing the Imposter God, p. 40.

믈:50 俩

DAEM ONS Pullman adopts a similar notion facility created for the trialing of 'intercision'- the by introducing his own 'dæmon'. Like Fletcher, with a 'silver guillotine'. Once severed, dæmons Pullman's functions as each character's 'guiding are locked in 'dæmon cages' where they eventually entity'. This entity exists as a manifestation of their perish.

soul who travels alongside them throughout life. A

character's outer visage represents one side of their Similar to Pullman's allegorical application of the self, while their dæmon, their 'soul', embodies the dæmon as someone's soul, the thesis proposes that other. "For Pullman, dæmons are not some clever a building's outer visage personifies its programme device for literary effect. Pullman uses them to or 'brand' in relation to a current identity-while highlight his trilogy's representation of human a building's 'dæmon' (soul) can be interpreted nature" (Freitas and King, 37). Pullman's dæmon as the temporal layers of underlying contextual evidences Fletcher's battle where allegorical narratives that define its place identity. The inner and outer selves.

work of architecture and its contextual heritag

In book one of Pullman's trilogy, Northern Lights, intercision with the silver guillotine-'soulless' protagonist Lyra finds herself captive and held in a urban architecture. 
intentions of Shagram analysing the allegorical

Kotahi', Hand Drawing. Author's Image

\subsubsection{FINE ART PROVOCATION}

SHANE COTTON

KENESIS:KOTAHI KI KOTAHI F o ll o w in g conveying perpetual movement and the inner coil the selection suggesting a return to the point of origin (Charles of a provocation Royal, np).

to the thesis intentiopresents a similar allegory

Kenesis: Kotahi Kions. The title of this painting This case study provocation could be considered as Kne on One. Hi Ki Kotahi translates as Genesis: an artistic interpretation of the Research Problem, One on One. Horizontal bands move upwards from where the layered concealment of the tree alludes to the darkness at the bottom to the light at the top, the loss of connection between the built world and becoming horizon lines of the landscape. Beneath the natural environment It reflects on the beginning the bands a tree is seen stretching upwards into of time when architecture was entirely a product the light. The more this tree enters the light, the of the landscape around it and thus people existed harder it becomes to see. In the darkness at the symbiotically within their environment. With the beginning of time, the connection of the tree to the evolving nature of modern building technologies, landscape is easiest to see. The double trunk of the architecture has steadily moved away from the tree becomes the double lines of the ' $\mathrm{P}$ ' in the word symbiotic model, seemingly towards Cotton's ' $\mathrm{p} \overline{\mathrm{o}}$ ', translating to darkness or night. The spiral is a 'white light', where a connection to the land is all traditional Māori symbol of creation, with the circle but erased. 

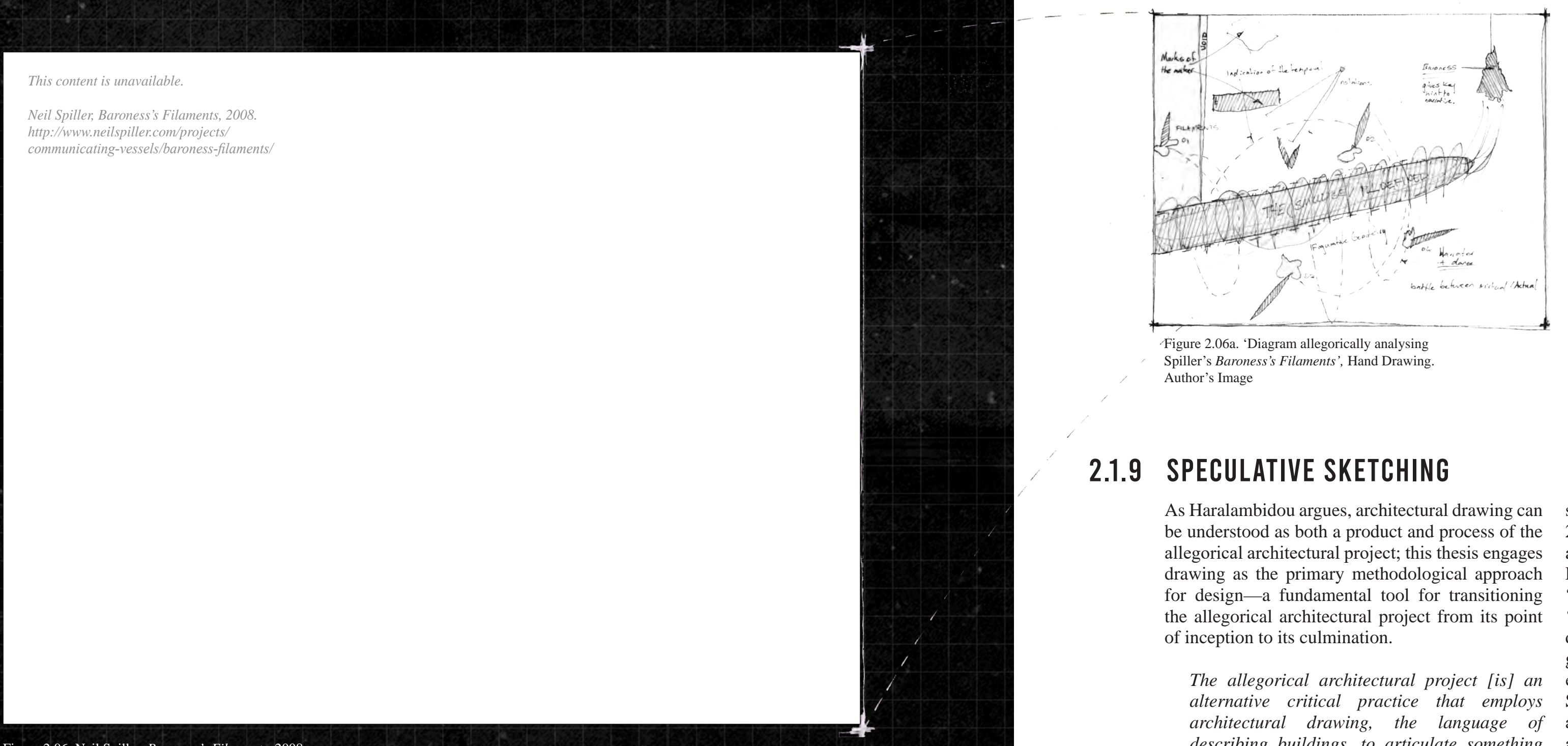

\subsubsection{SPECULATIVE SKETCHING}

As Haralambidou argues, architectural drawing can shown in his drawing Baroness's Filaments (fig. be understood as both a product and process of the 2.06), where Spiller explores both the virtual and allegorical architectural project; this thesis engages actual simultaneously. The Baroness is inspired by drawing as the primary methodological approach Duchamp's 'Bride' in the Large Glass, who projects for design - a fundamental tool for transitioning 'filaments' to keep a missing piece of the glass. The

the allegorical architectural project from its point 'Baroness' (Spiller, "Baroness's Filaments”, np) is
of inception to its culmination.
described by Spiller as the 'juggler', the 'handler of of inception to its culmination. gravity' who maintains a precarious and readjustin

The allegorical architectural project [is] an equilibrium. In the context of this free hand sketch, alternative critical practice that employs Spiller argues for the ability to be vague, intuitive architectural drawing, the language of and ill-defined as crucial in the conception of describing buildings, to articulate something allegorical architecture. He advocates for the 'other'...

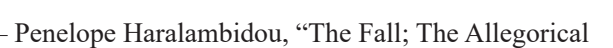
Project as a Critical Method", p. 225 allity of the skech and he advecas for the ability of the sketch and the re-sketching of the sketch as fundming to releasing a "cascade of creative architectural ideas'”(Spiller, In Praise of the Blur, 133)

Speculative drawing theorist Neil Spiller has Section 2.2 of this chapter presents Design Stage written and practiced extensively in relation to the 01 , which privileges speculative freehand sketches ropic on speculative architectral drawing. In his as a means of arriving at the 'Inception' of the ing in preliminary stages of conception (Spiller "In is engaged-providing a means to progress initial Praise of the Blur", 133). An example of this is sketch design experiments.

It is vitally important for an architect at the beginning of a design to the sketch is done, it needs to be reread resketched or discarded One of the great things about sketches is that they are sponTanneous. Working with the greal ings about sherches is that hey are spon Taneous. Working with the possibility for an architect to experience his or her proposal with the visceral feeling so immediate as one draws. 


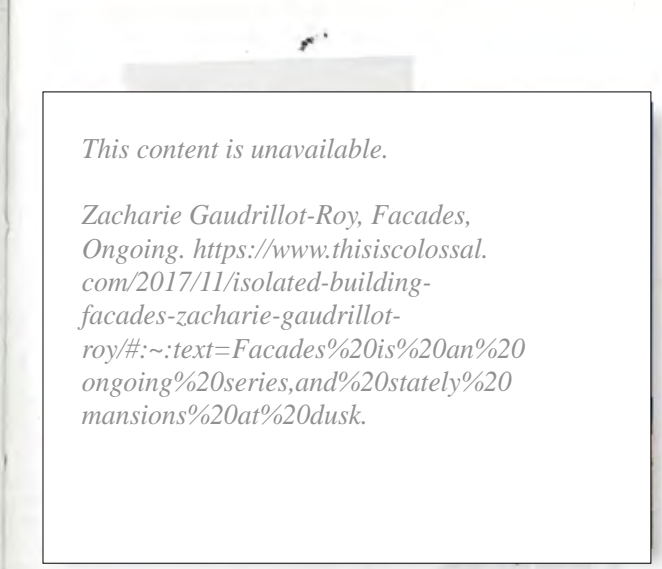

Facinde as Arehitecture's Mask?

Mask as Cage?

This content is unavailable

Dan Slavinsky, 'Possibilitites of a Threshold', Drawings From the End of
Time. 2010. http://llucydunnarchi.blogspot.

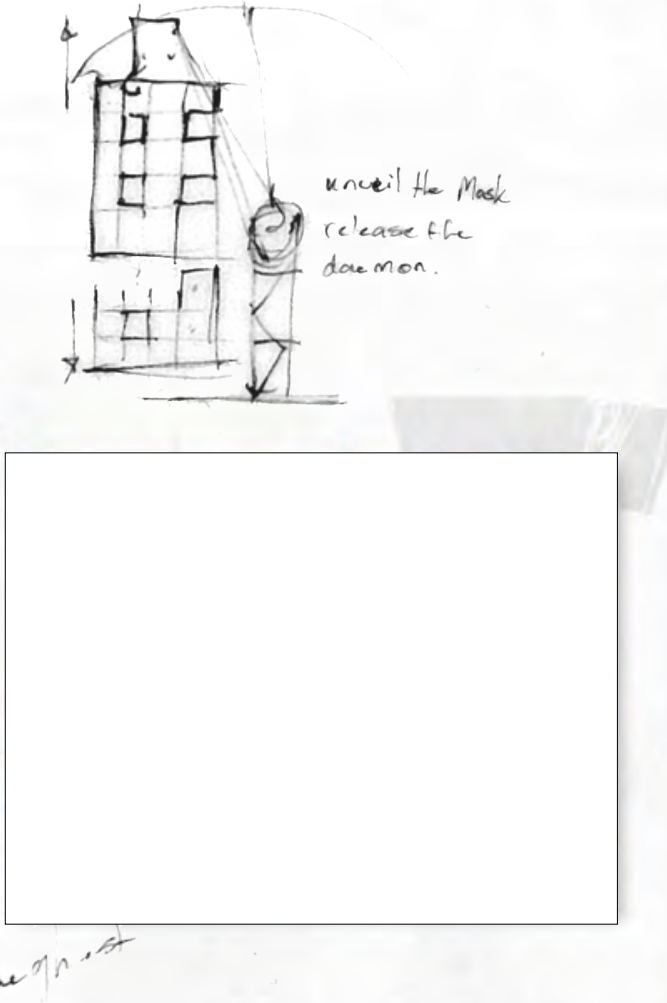

66

The modern wall is nothing like its stony counterpart. It is now composed of many layers, some hidden and some revealed... the surfaces of the wall become marginally distasteful. The surface appears to hang in front of something as if it were a screen to the wish to present a mirage of so, due to the wish to present a mirage more socially palatable.
목:吅 啉

2.2.1 INCEPTION:

THE DAEMON CAGES

CASE STUDIES In Pullman's allegorical literary trilogy, the 'Dæmon where victims (outer self) and their dæmons (inne self) are held apart during the process of 'intercision', an attempt by the magisterium (authority), to sever the person from their dæmon. The following case studies were selected as possible architectural links to Pullman’s dæmon cages.

THE OUTER French photographer Zachari Gaudrillot-Roy designed a

ongoing architectural series titled 'Façades', where he deconstructs urban landscapes, reducing them to mere masks of the buildings that populated them The digital buildings exhibit an eerie absence of construction's mass. This case study was interpreted as the outer self of architecture, severed from al internal elements, becoming both a mask and cage, which typically concealed architecture’s dæmon.

THE INNER In fig. 2.08, the fluid and anthropomorphic drawing style of Dan Slavinsky, Associate Director of Astudio Architects in London, depicts a hybrid of plan and section, where architecture is depicted as surreal biomorphic organisms. In this concept design stage of the thesis, Slavinsky's drawing style is interpreted and adopted to engage the initial 'soul' of architecture- a fluid, dynamic and sinuous
Opposite Below | Figure 2.08a.
Dan Slavinsky, 'Possibilities of Dan Slavinsky, '
Threshold 2010. 


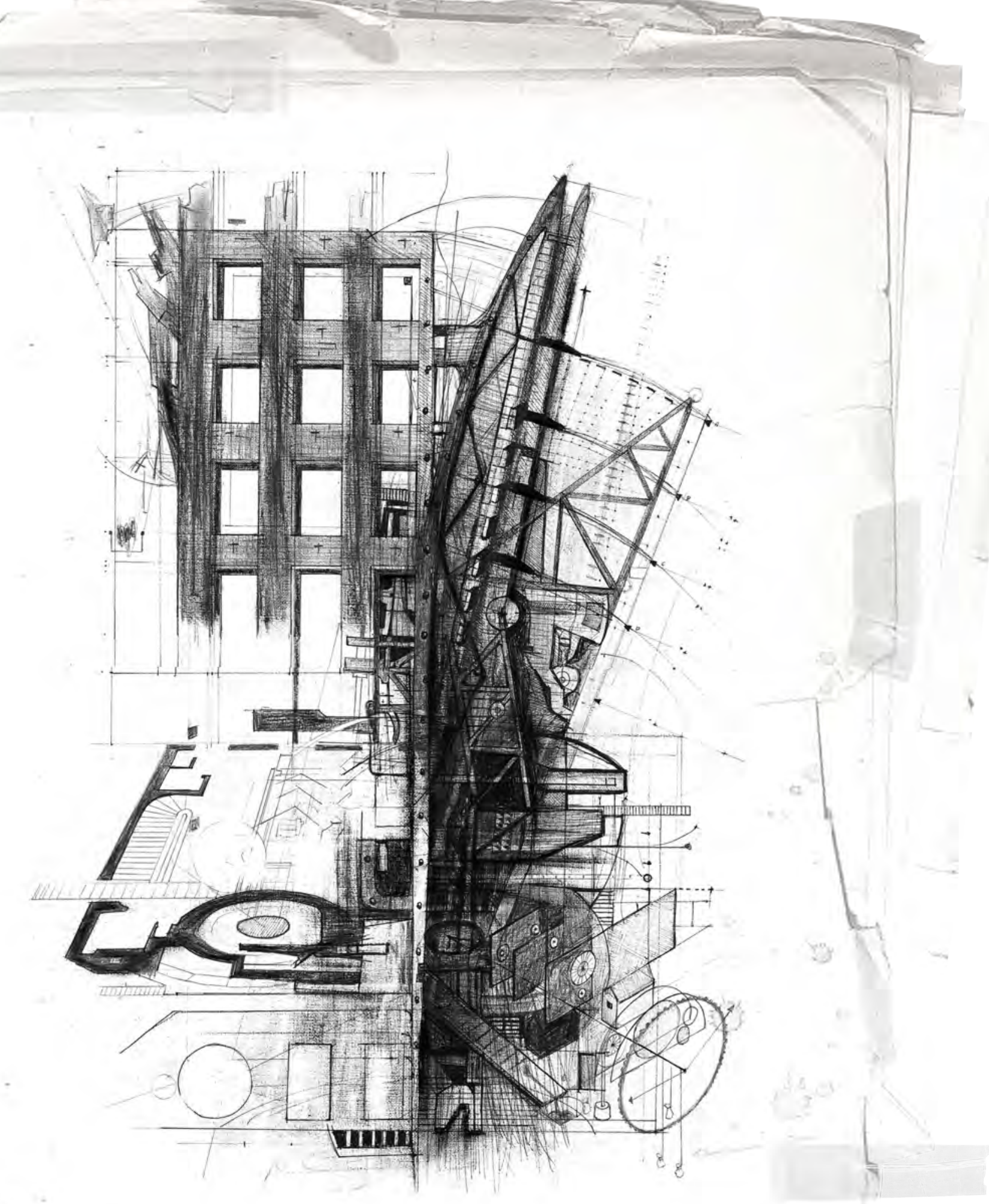

吗:20

66

In a series of glass cages on shelves around the walls were all the dcemons of the severed children: ghost-like forms of cats, or birds, or rats, or other creatures, each bewildered and frightened and as pale as smoke.

— Philip Pullman, His Dark Materials, p. 215.

01 SKETCH

In fig. 2.09 the concept of

is translated through an allegorical architectura drawing sited upon the pages of the sketchbook. In this experiment, the 'dæmon cage of architecture' presents itself as a traditional facade cut and separated from its floor plan. A timeline indicate hat the gap between the facade and the groun floor beneath it is growing in a temporal manner--a reference to Shane Cotton's layering of time in Kenesis; Kotahi Ki Kotahi. The right side of the drawing represents the cause of the problemallegorically manifested as the silver guillotine. The left side represents the effect- - the severing
the connection between architecture and site. 02 RE-SKETCH According to Spiller, "Once to be reread, resketched or discarded" (Spiller, "In Praise of the Blur", p. 133). In fig. 2.10 (overleaf), the drawing is then re-sketched activating Fletcher's symbolic action 'battle' through the placement of the same drawing, mirrored in opposition. The key to interpreting the drawing is revealed through this opposition, evidenced by an revere paper, treacing paper, tape and stains, while the right appears in

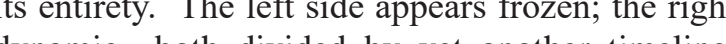
A swift bo divided by yet another timeline. A swift blur of lines embodies the dæmon which ultimes from the void on the right. The drawing back is context beneath. In this recketche context beneth the 'sketchbook site' appers as a dark void between the rips and frays of lowe a dark void between the rips and frays of lower Perpetual Night. 


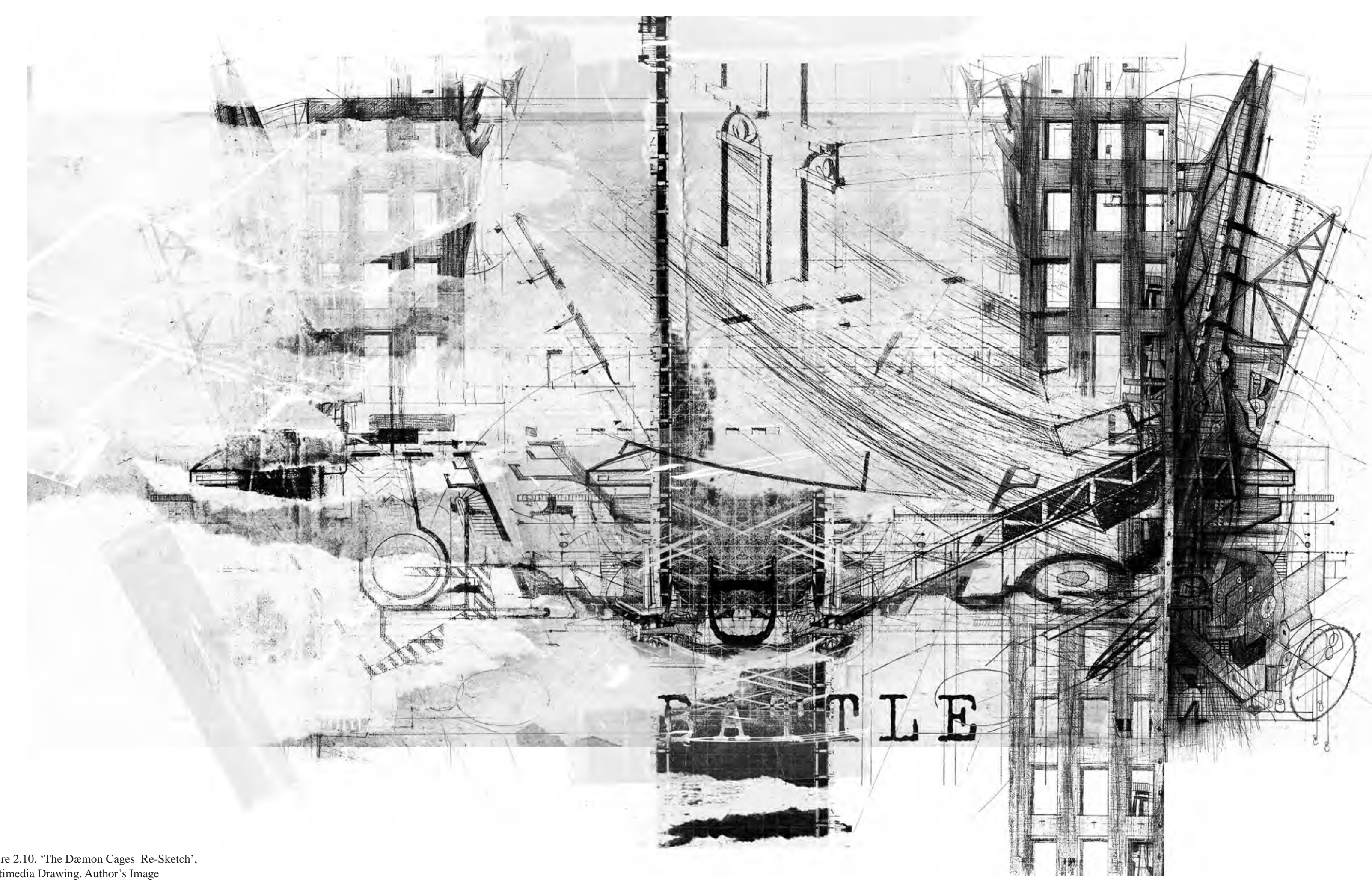


093:40 Dftuct pivatpoint-

66

Everywhere it is machines-real ones, not figurative ones: machines driving other machines, machines being

driven by other machines, with all the necessary couplings and connections. - Gilles Deleuze and Guattari Félix,
Anti-Oedipus: Capitalism and Schizophrenia, p. 01 .
2.2.2 INCEPTION:

THE SILVER GUILLOTINE

\section{CASE STUDIES}

The 'Silver Guillotine' is a device engineere to separate a person from their dæmon, severing the bond bes pering is interpreted as a symbol of disconnection, the initial division between architecture and site. MECHANISM In fig. 2.11 A. L. Moure architectural plan drawing is used as a case study in Design Stage 01 to help establish an architectural interpretation of the guillotine, presented at a large scale. The dynamic, mechanistic inspired architectural language provides an example of how the guillotine may be represented through drawing.

\section{DYNAMICS}

$$
\text { In fig. 2.11a, Kirril }
$$

Chelushkin's architectural Dested artwork is also used as a case study in Design Stage 01, interpreted as a depiction of the guillotine. Here the style of drawing, with its somewhat organised, yet sporadic freehand line work, provides an interesting example aligning with Spiller's description of the preliminary imaginative (n) in Fig 2.12 (oving ar guillotine structure, slicing beneth the ground plane

guillotine structure, slicing beneath the ground plane
of a floor plan. 


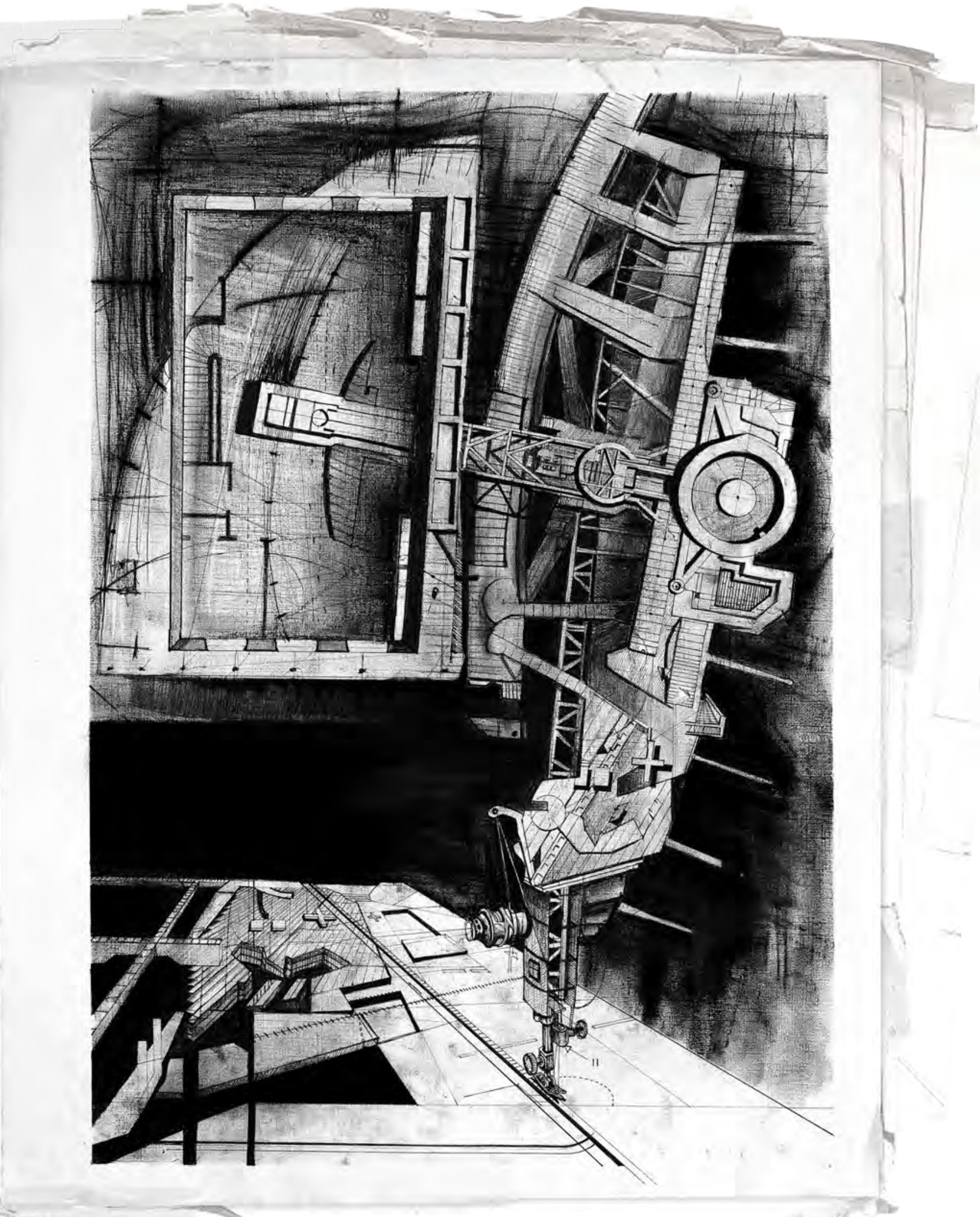

So we've developed a kind of guillotine... the blade is made of megnesium and titanium alloy, and the child is placed in compartinent-like a small cabin- of alloy mesh, with the demon in a similar compartment connecting with it. Then the blade is brought down between them, severing the link at once. They are then separate entities.

01 SKETCH

stage experiment shown the silver guillotine is reimagined as an allegorical architectural device, combining both Strangis's and Chelushkin's case studies to transform Pullman's fictional provocation into speculative architectural interpretation. The drawing depicts the mechanisms of the guillotine in a single moment, where the blade is part way through its swing. The guillotine itself exists allegorically on the threshold between sketchbook and void, where it functions simultaneously as a generative device, acting as both the provocation and foundation of allegorical project. Hand Drawing. Author's Image

Overleaf | Figure 2.13. 'The Dæmon Cages',
02 RE-SKETCH In fig. 2.13 (overleaf) the leaf) the is re-sketched, this time in relation to Fletcher's In this initial stage, progress is engaged through of objects in a sequence of space although experienced statically, becomes

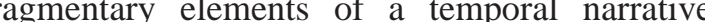
The left side of the drawing depicts the realm of ve sketchbook, and the darkness on the right, the vold. The 'sketchbook site' is depicted beneath the vorplan, peeling away into the darkness of the void beneath, as if ripped away by the action of the guillocine. Behind the initial layer, other layers can be seen disappearing into the void, indicating 'progress' through a repetition of the guillotine's will it be is is not the beginning, and neither will it be the end. Along the lower edge appears yet another timeline, fragmented in relation to the threshold's transitional conditions. This timeline represents Fetcher's concept of 'progress' from the sketchbook into the void, stepping through layers the centre point to witness the guillot, stopping a bring into fragments through the crossing of the threshold. 

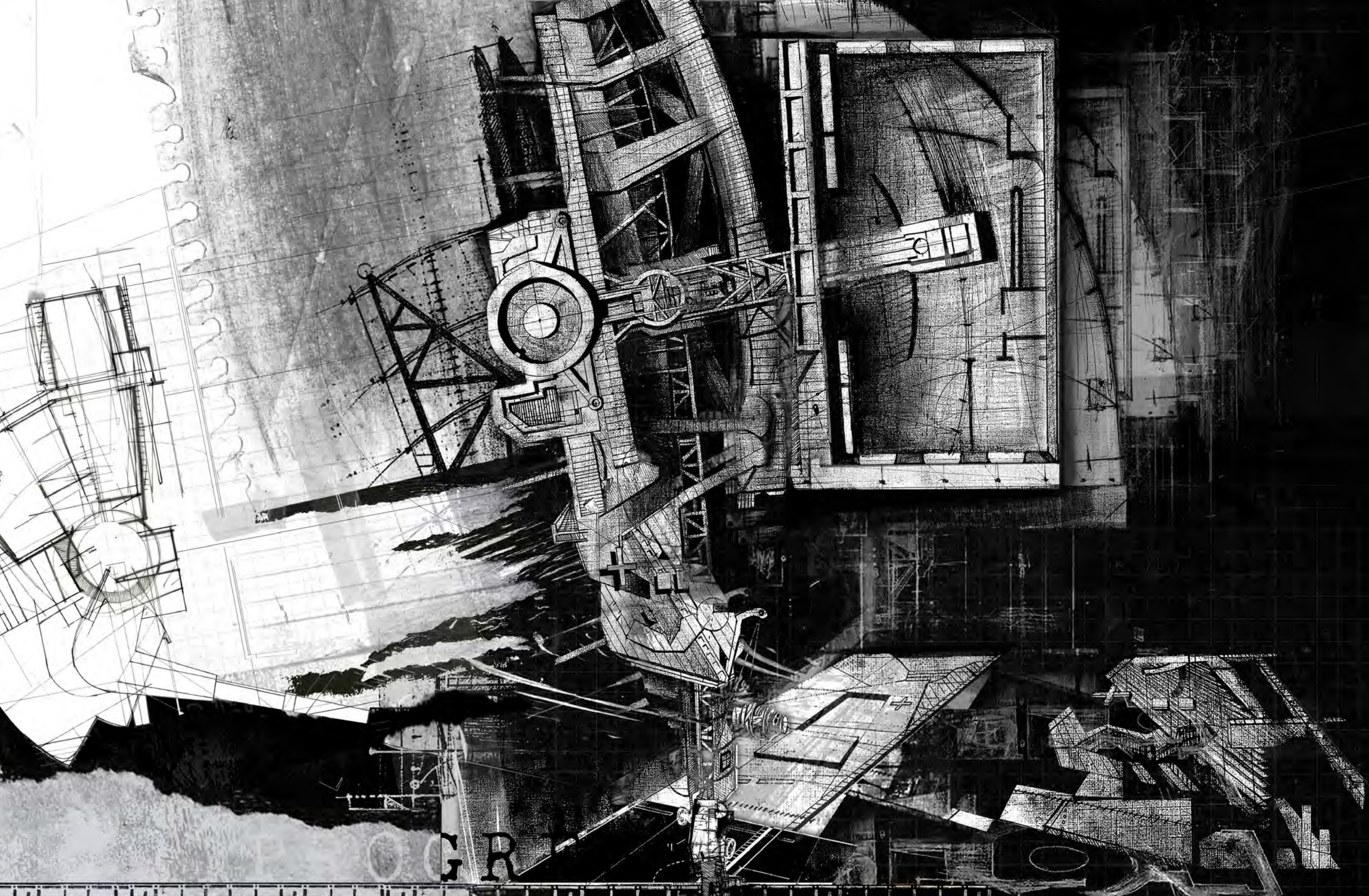

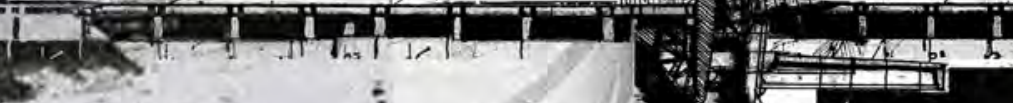

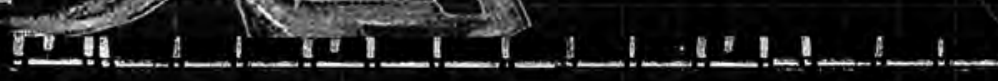




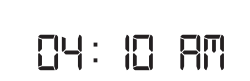

66

Throughout antiquity in cultures around the globe, gold was considered precious not only as a means of wealth but also for a range of physical and spiritual properties ascribed to the lustrous metal, often viewed as a direct product of the divine because of its beauty.

Shannon L Venable, Gold : A Cultural Encyclopedia, 2011.

WOAD-PERPETUAL NIGAT $\sum_{i}^{2}$

है.

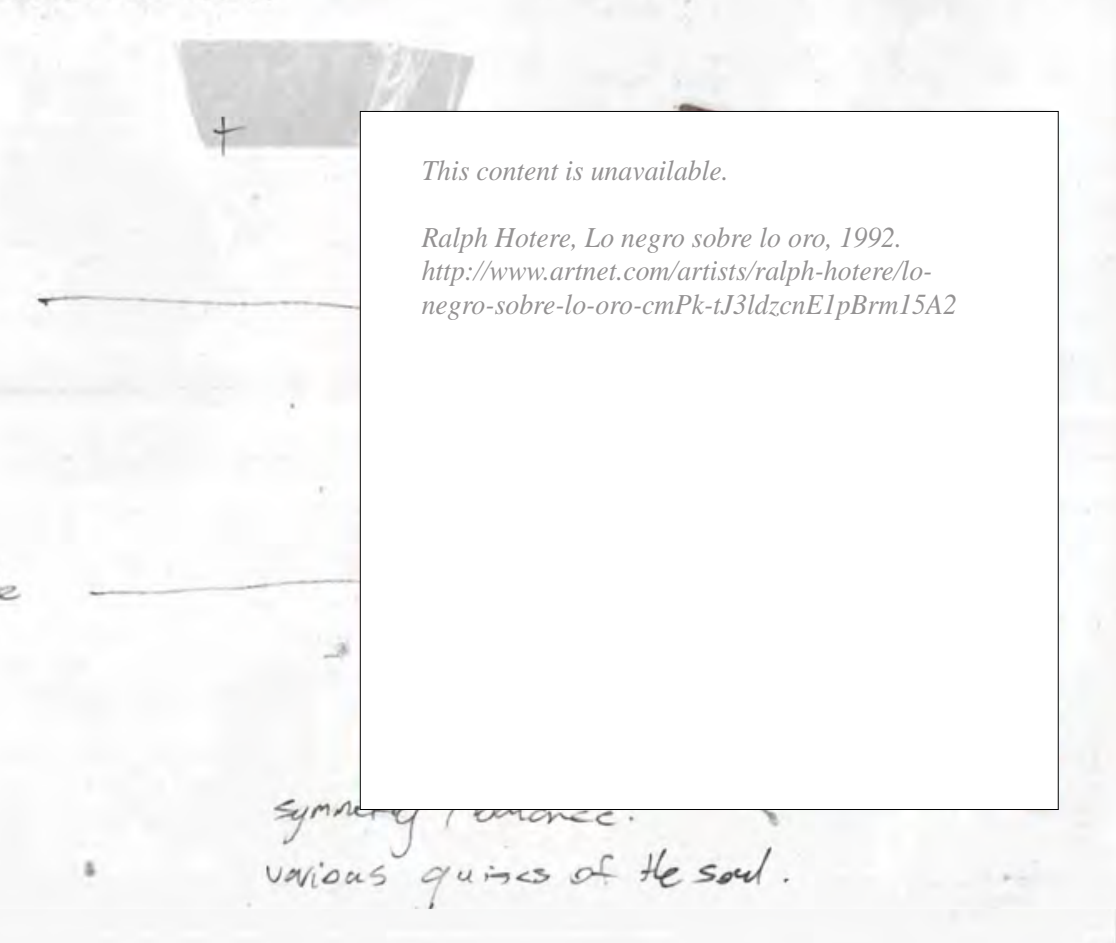

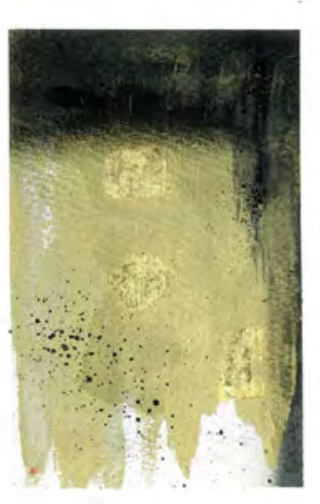

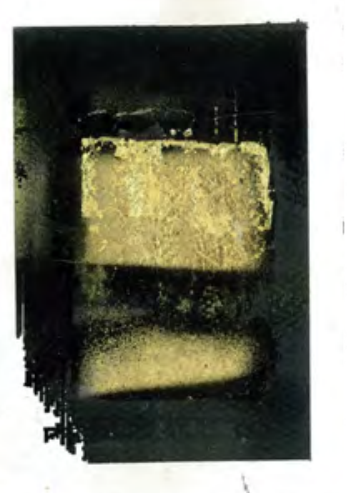

Opposite | Figure 2.14. Ralph Hotere,

Above | Figure 2.14a. 'Gold Leaf

Experiments', Author's Image
2.2.3 INCEPTION:

ARCHITECTURE'S DAEMON

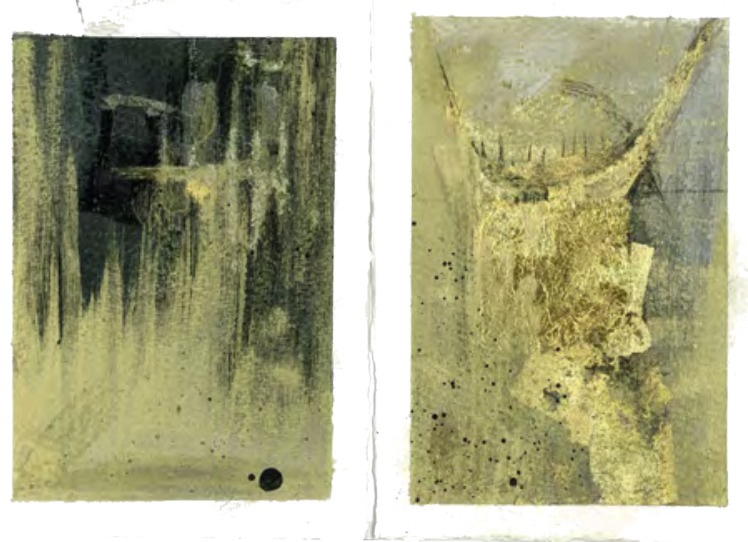

\section{CASE STUDIES}

describes 'Dust', e

with consciousness and the poutticles associated

if you have the ability to see them. In his 2019

sequel to His Dark Materials, called The Secret
Commonwealth, Pullman describes 'Dust'

follows:

The street below her was saturated in Dust. Human lives were generating it, being sustained

if it was touched by gold. [Lyra] could almos

if it was touched by gold. [Lyra] could almost

every circumstance, the all was well and the

the world was her true home.
Māori artist Ralph Hotere's painting series Lo Negro Sobre Lo Oro is selected as an additiona case study for the concept design stage of the thesis investigation. Hotere's application of gold leaf on black is interpreted as a material indication of the spiritual and divine. In a similar sense, the gold leaf experiments above were conducted by the author as a preliminary test of texture and color, exploring his notion of gold as a representation of the sou
'touched with gold' and 'true home'. 


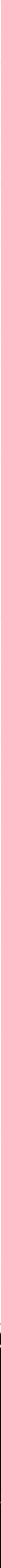




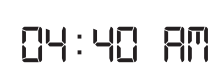

\section{6}

Drawing Architectures is about being true to yourself as an architectural designer. It is about having the bravado and the ego to put your head above the parapet and shout 'this is me - this is what I do, this is what excites me and this is how I go about describing it'.

$$
\text { — Niel Spiller, Drawing Architectures, p. } 15 .
$$

\subsubsection{INCEPTION}

CRITICAL REFLECTION

an initial exploration of RO1: 
Then at last Täne, the god of and father of the forests, slowly stood up..

He strained his back in a mighty effort, and he tore apart his parents..

...far, far beneath him he pressed the earth; far, far above him he thrust the sky...

$$
\text { — Te Ao Hou, The Story of Rangi and Papa, p. } 28 .
$$

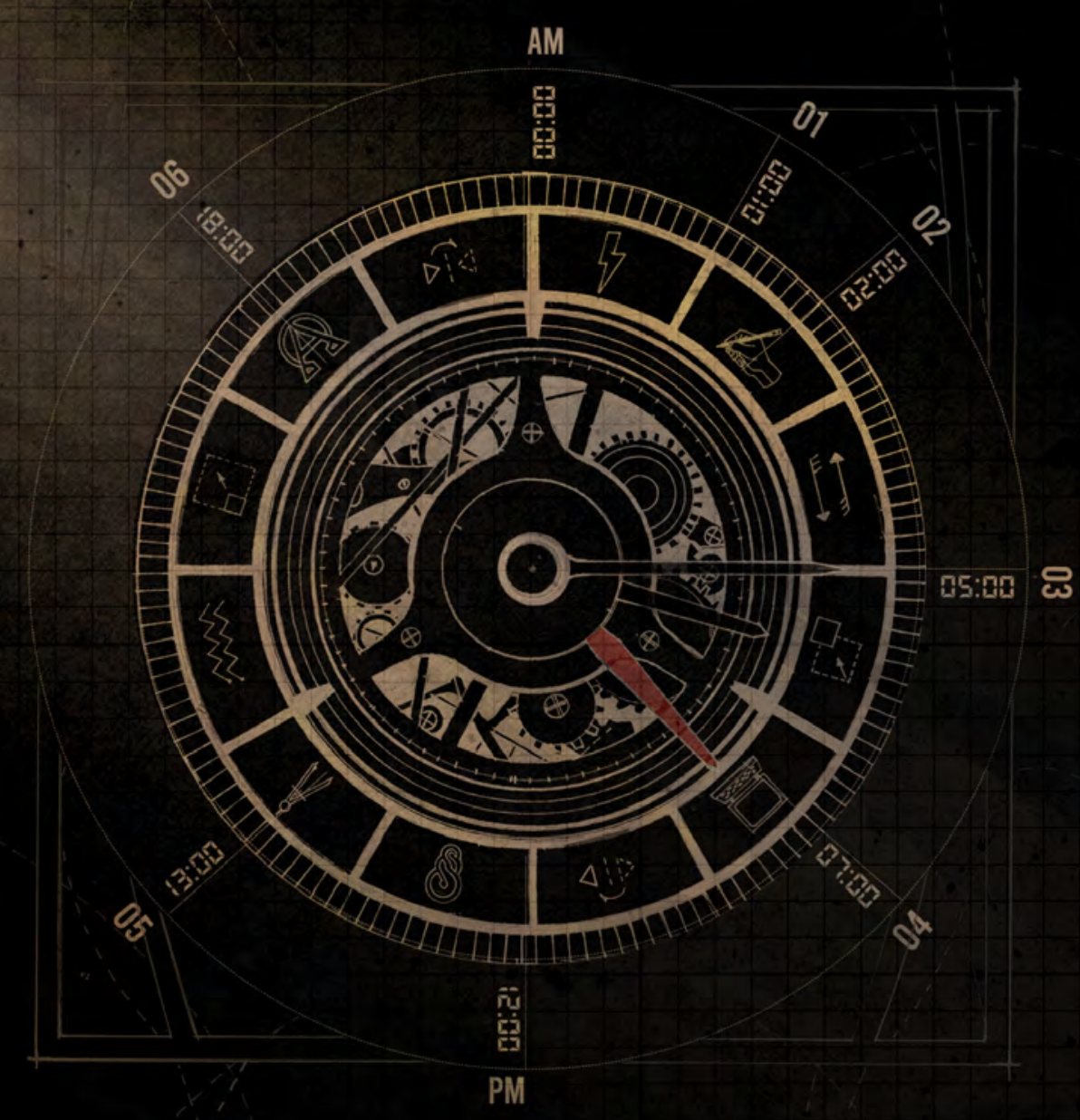

HAEATA | BEAM OF LIGHT, SUNRISE LITERATURE AND PROJECT REVIEW 
There are many things we haven't yet learned how to read. The story in this book is partly about that very process.

- Philip Pullman, Lyra's Oxford, p. 02.

But first whom shall we send In search of this new world, whom shall we find In search of the new wortd, whom shall we find Sufficient? Who shall tempt, with wand'ring feet
The dark unbottomed infinite abyss,

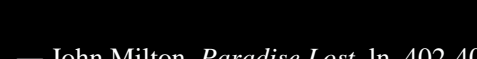

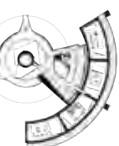

CHAPTER 03 This chapter, "Haeata | Beam of Light, Sunrise", represents the theoretical and contextua foundation for the Preliminary Design Stages of the investigation. The chapter is divided into the following two sections, which together provide foundation for the design-led research experiments in the Preliminary Design Stage (Chapter 04.)

3.1. The first section is the Literature and Project Review for the two Preliminary Design stages of the hesis (Cognition: Design Stage 02 and Activation: Design Stage 03). This section is divided into four subsections; Architectural Battle or Confrontation (R02); Architectural Progress or Journey (R03); Spatial and Temporal Provocations (R02 \& R03); and finally, 'The Battlefield'. The goal of Section 3.1 is to introduce theorists and case studies to address both $\mathrm{RO} 2$ and $\mathrm{RO}$. 3.2. The second section is a Contextual Analysis for the two research sites used in the Prelimin Design Stages (Cognition and Activation) of the thesis investigation.

R02: Allegory as Battle (Confrontation) To explore how the representation of allegorical architecture as battle or confrontation can help establish contextual dialogues (spatial relationships) that help unveil the essential heritage stories relating to a site.

\section{R03: Allegory as Progress (Journey)} To explore how the representation of allegorical establish temporal qualities (time-based relationships) that help unveil the essential reritage stories relating to a site. 
3.1. ARCHITECTURAL BATTLE

DIALECTIC(S)

The method of reasoning that proceeds by question and answer and logical argument, famously illustrated by the dialogues of Socrates (470-399 bce)...

at base a discourse between two or more people holding different points of view about a subject but wishing to establish the truth through reasoned methods of argumentation.

- John M Last, A Dictionary of Public Health , p. 67.

\section{OR CONFRONTATION}

the notion of battle or confrontation requires dualities or 'oppositions'. In order to instigate a 'dialectic' opposition between site and architecture, a link is made between Fletcher's 'battle' in where 'battle' can be interpreted as an allegorical action, occurring as a result of an architectural confrontation. This stage of the thesis reflects on confrontation in architecture, observing the many forms in which allegory in the form of 'battle' may be presented. Raimund Abraham, in his book [UN] Built, describes 'confrontation', 'dialectics' and 'collisions' in relation to architecture

But while the search for the ideal demand's contemplation, critique, and experimentation utility succumbs to the inescapable habit of routine. The conflict and confrontation between theory and practice forms the dialectical foundation for all attempts to think or to make architecture. architecture.

Raimund Abraham, [UN]Built, p. 113

Abraham then discusses confrontation in relation to memory. He argues that in architecture a confrontation occurs between the physical and He attributes aising coflicts as fundenet in the defining of architectural elenets and spatial structures, suggesting that a dialectical confrontation between the physical and historical of meaningful metaphors of place (Abraham, 113). In relation to the confrontation of site and project, Abraham describes any architectural endeavor with site as an act of 'collision', suggesting that confrontation is intrinsically at the root of architectural conception.

In my work, collision as a metaphor plays a salient role as a physical or syntactic manifestation. I believe that the dialectical principle of "collision" is the ontological basis of architecture.... Any architectural endeavour is an interference with this site. One either builds up into the sky or down into the earth. Raimund Abraham, [UN]Built, p. 113

Abraham considers the process of design as the secondary and subsequent act of the confrontation, with the purpose being to reconcile and harmonise the consequences of the initial collision (Abraham, 114) A similar description of (Abraham, 'confrontation' and 'collision' is adopted within 'che thesis investigation, providing a foundation for Fletcher's allegorical 'battle', This allegoric 'battle' is not necessarily a conflict, but instead a ttempt to reconcile the initial site conf inted an inviting both opposing identities to become an integral part of the architectural outcome. 


\subsubsection{ARCHITECTURAL PROGRESS}

\section{OR JOURNEY}

Fletcher's 'progress' or journey is lished between the 'temporal experience' of architecture as an allegorical journey. In his article "Montage and Architecture", Sergei Eisenstein draws a link between the cinematic montage of film and the temporal experience of architecture, describing two fundamental ways that time is manifested within architectural conception. Initially Eisenstein draws a link between cinematic montaging and the traditional physical experience of architecture, where the viewer must physically move through a temporal journey of spaces and thresholds in order to interpret a holistic architectural nertive Eisentstein, 112). Eisenstein's description of this architectural jouney miros Fletche's description of aleorical 'progress', where the undely.ing meaning is revealed through the seuential sages .

Eisentstein then describes architectural montage in relation to the static image, where the viewervirtual joun in a fixed position-embarks on a composite the tempors is a product of the viewer's interpretation. Eisenstein suggests that the static image holds the potential

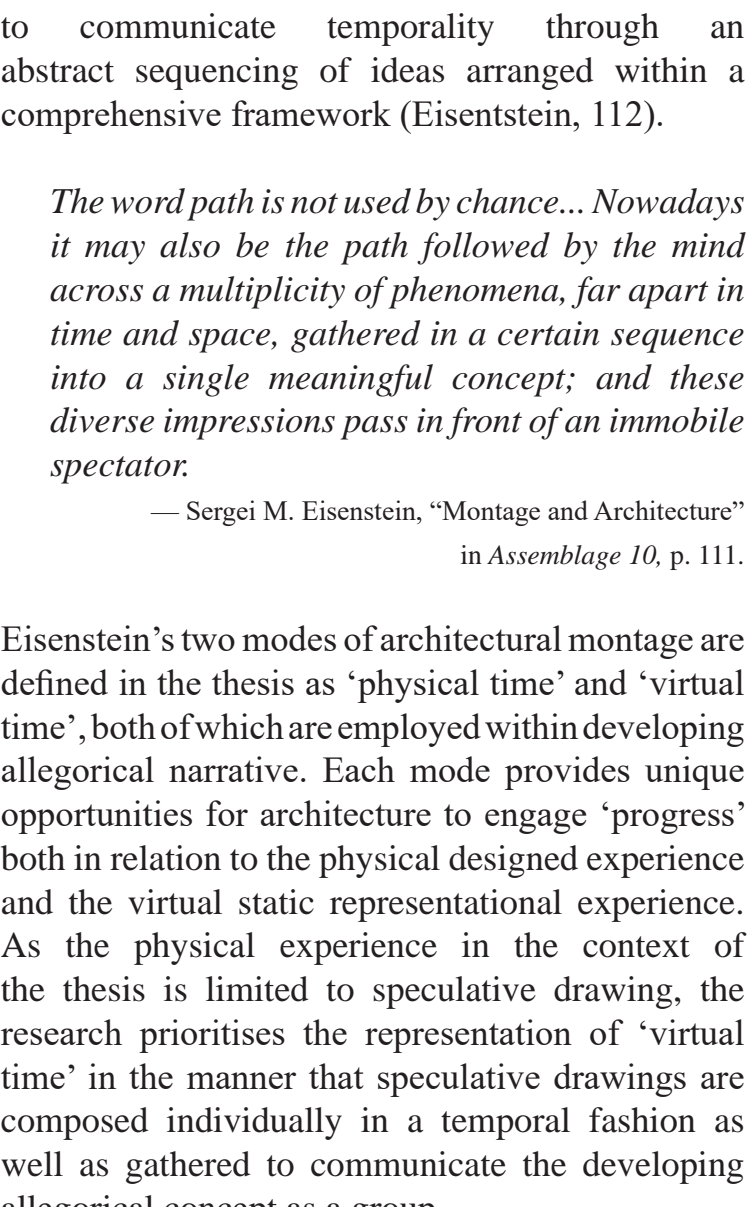

o communicate temporality through an cequencing of ideas arranged within a comprehensive framework (Eisentstein, 112).

The word path is not used by chance... Nowadays it may also be the path followed by the mind across a multiplicity of phenomena far apart in time and space, gathered in a certain sequence into a single meaningful concept; and these diverse impressions pass in front of an immobile spectator.

- Sergei M. Eisenstein, "Montage and Architecture" in Assemblage 10, p. 111

Eisenstein's two modes of architectural montage are defined in the thesis as 'physical time' and 'ving ime' both of thich as 'phployed with' 'llegorical narative. Each mode provides uniqu opportunites for architecture to engag 'progress' both in relation to the physical designed experience and the victic stapresentational experience. As the physical experience in the context of the thesis is limited to speculative drawing the

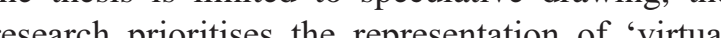
ime' in phe mithe the

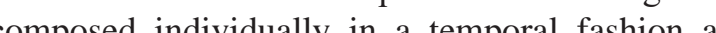
well as gathered to communicate the devloping well as gathe 
Ninitio
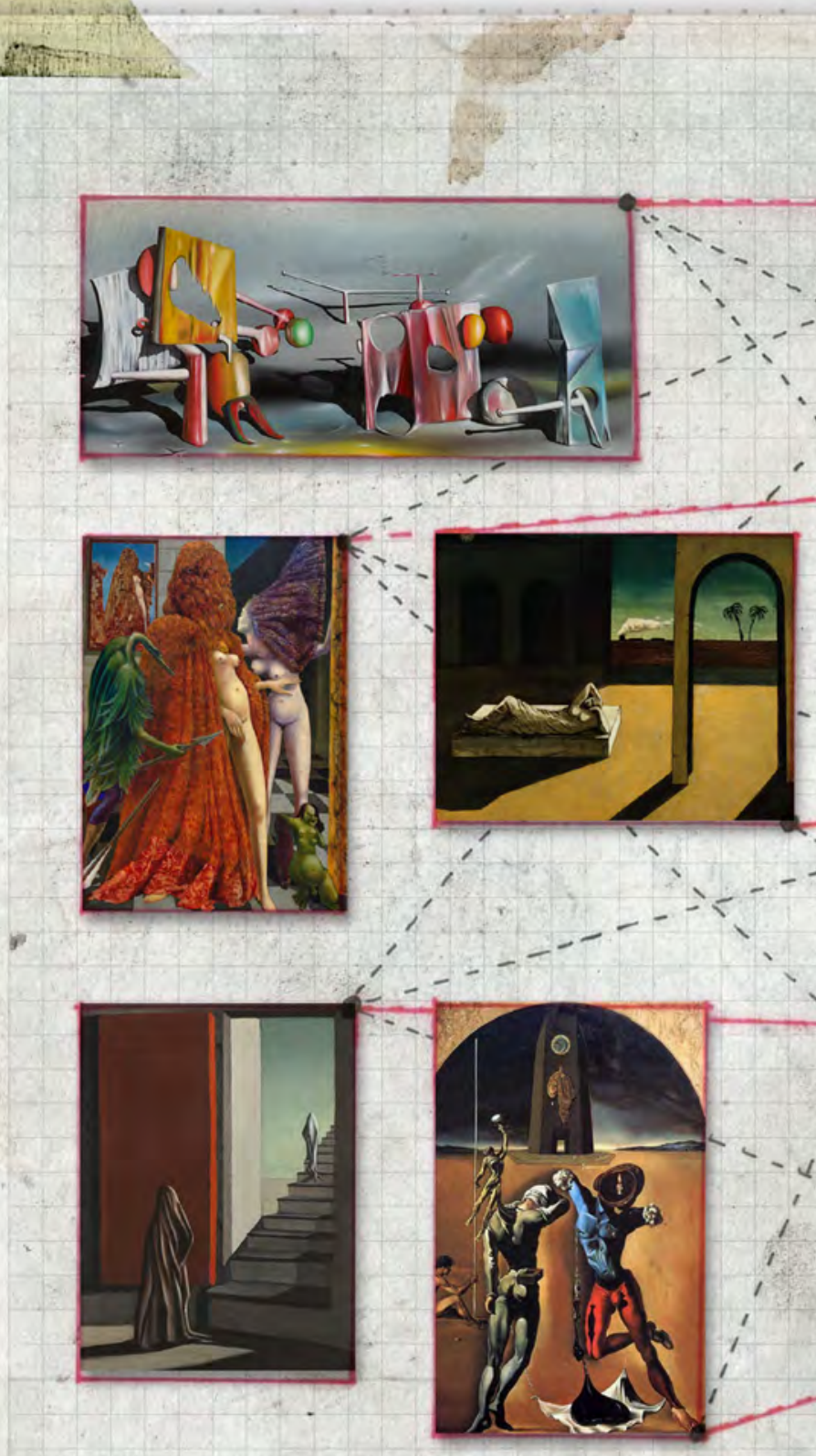

Categories of duadity - canbe applied to malliple
yot selfected for permary one.

05: 9017

\section{O1 MIRROR}

O2 MASK

DOF FRAME

O4 THRESHOLD

05. DANCE

$$
\begin{gathered}
\text { Key _.... Primary link to Art } \\
\ldots \text { Secondacy link Act } \\
\ldots \text { s.rimarg liak to Arohitedure. }
\end{gathered}
$$

C6

Let us not mince words: the marvellous is always eautiful anything marvellous is beautiful, in fact only the marvellous is beautiful.

- André Breton, Manifesto of Surrealism, p.04

\subsubsection{SPATIAL}

PROVOCATIONS

Relevant examples of allegorical Surrealist paintings were selected as case studiesto help translate Fletcher's concept of 'battle' and 'confrontation' from its theoretical foundation into the spatial and compositional realm of conceptual architecture. primarily for its spatial allegorical manifestation of a 'battle', while also incorporating architecture in some way.

The investigation of Surrealist paintings revealed five key approsches to allegorically representing 'battle' or 'confrontation': the mirror, the mask, the threshold, the frame and the dance. The investigation next paired a principal Surrealist case study representing each approach with an architectural case study that could be interpreted in a similar way. Because the architectural case studies were presented three-dimensionally and could be experienced from multiple points of view, they provided a vehicle with which could be interpreted architecturally. In the following drawing experiments, these redepicted through a filmic montage, inviting the 'battle' to be reflected simulTāneously through temporal 'progress' Interrogation of the outcomes reveals five interrelated devices of allegorical battle (minor, mask, threshold, frame and dance) each of which is used to fuel preliminary design experiments in Design Stages 02 and 03 
This content is unavailable.

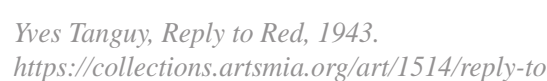

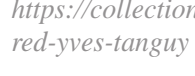

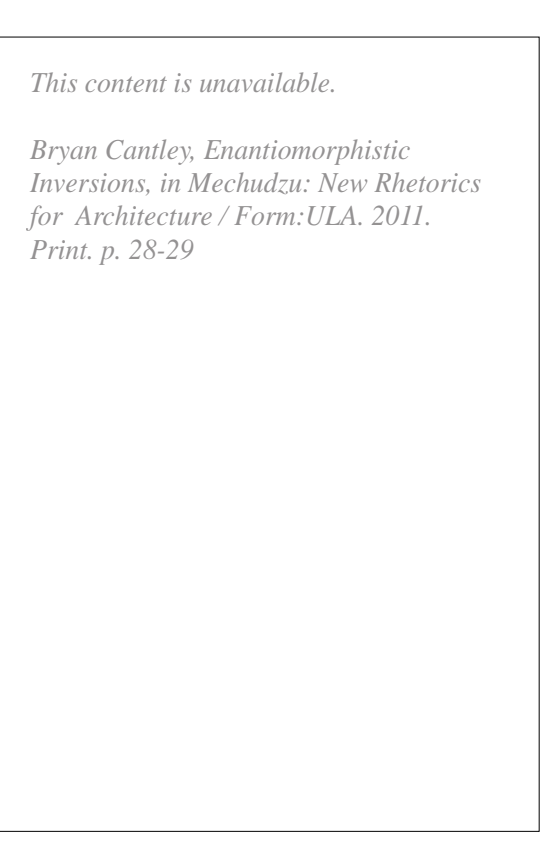

ENANTIOMORPHISTIC INVERSIONS,

BRYAN CANTLEY Bryan Cantley's design for Enantiomorphistic Inversions (2011) was selected as an architectural case study that represents similar characteristics to those used by Tanguy in Reply to Red to establish the 'mirror'. Inspired by Lewis Carroll's book Through the Looking Glass, where Alice enters Wonderland through a mirror (Cantley, Mechudzu, 28), this speculative architectural precedent was selected due to its expression of two sides of self, divided by a "mirror". Cantley's mechanical approach to design celebrates and prioritises both services and structure, utilising its dynamic nature to articulate the complex narrative.

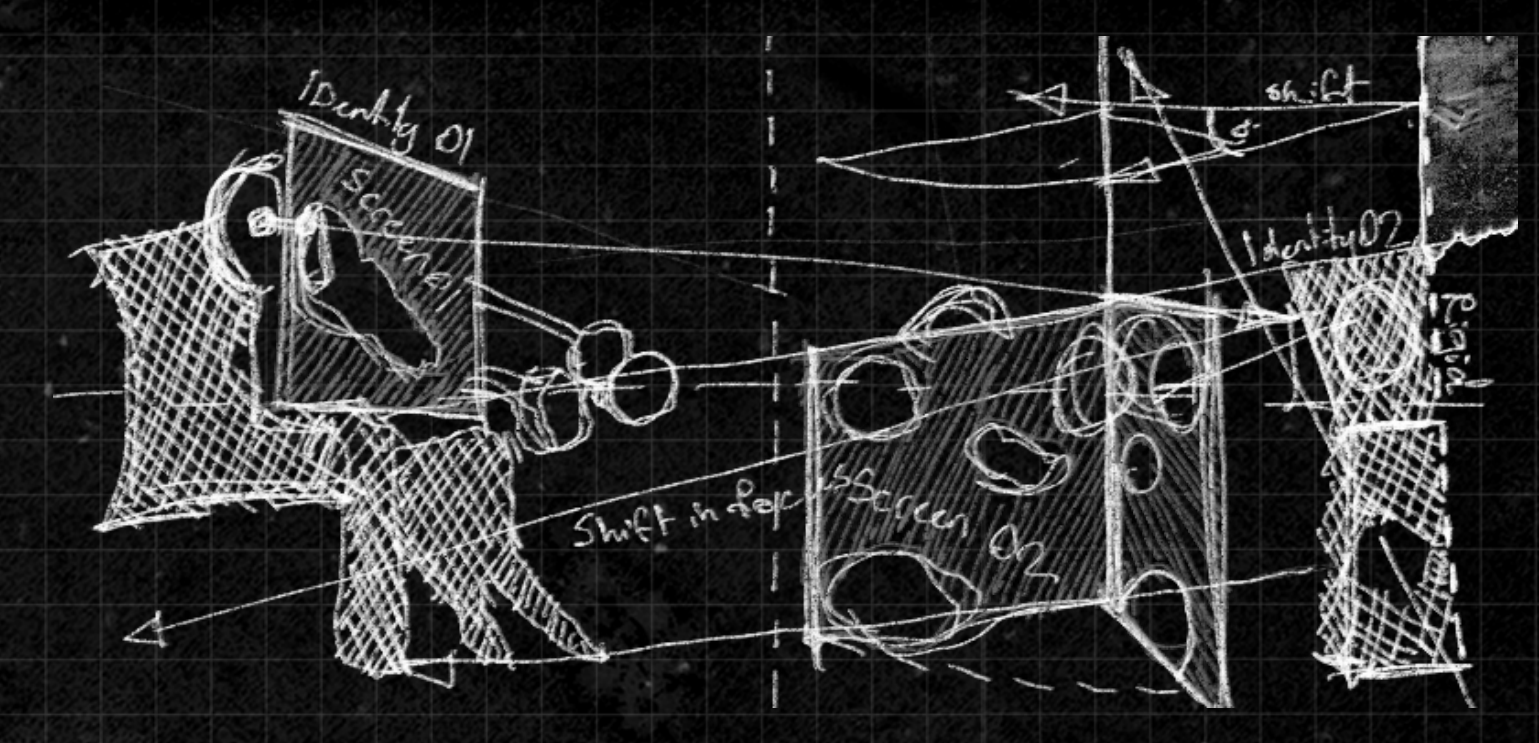

REPLY TO RED, YVES TANGUY

Y v e s conflicting self. The second, perforated veil may

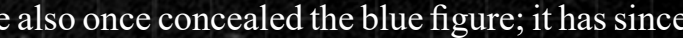
Surrealist painting Reply to Red (1943) was selected been removed. The blue figure appears resultantly as a case study that establishes a 'confrontation' somber with its low gaze. The architectural gable through the allegorical approach of 'the mirror'. shaped head appears as if it is hooded, obscured; The entity on the left directly contrasts that on the we are unable to see its face. Despite this, it holds right - both in color and attitude - its expression a sturdy form, and through this rigidity, becomes a could be considered as reticent, as it hides behind fundamental aspect of the composition. a torn veil, peering back through at its other

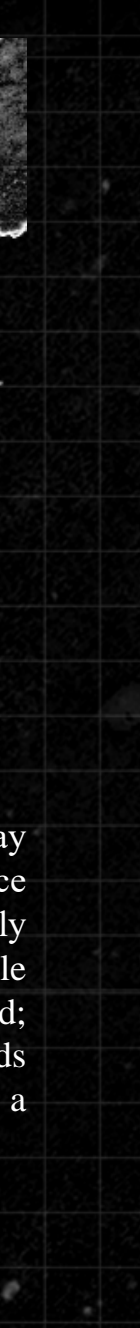

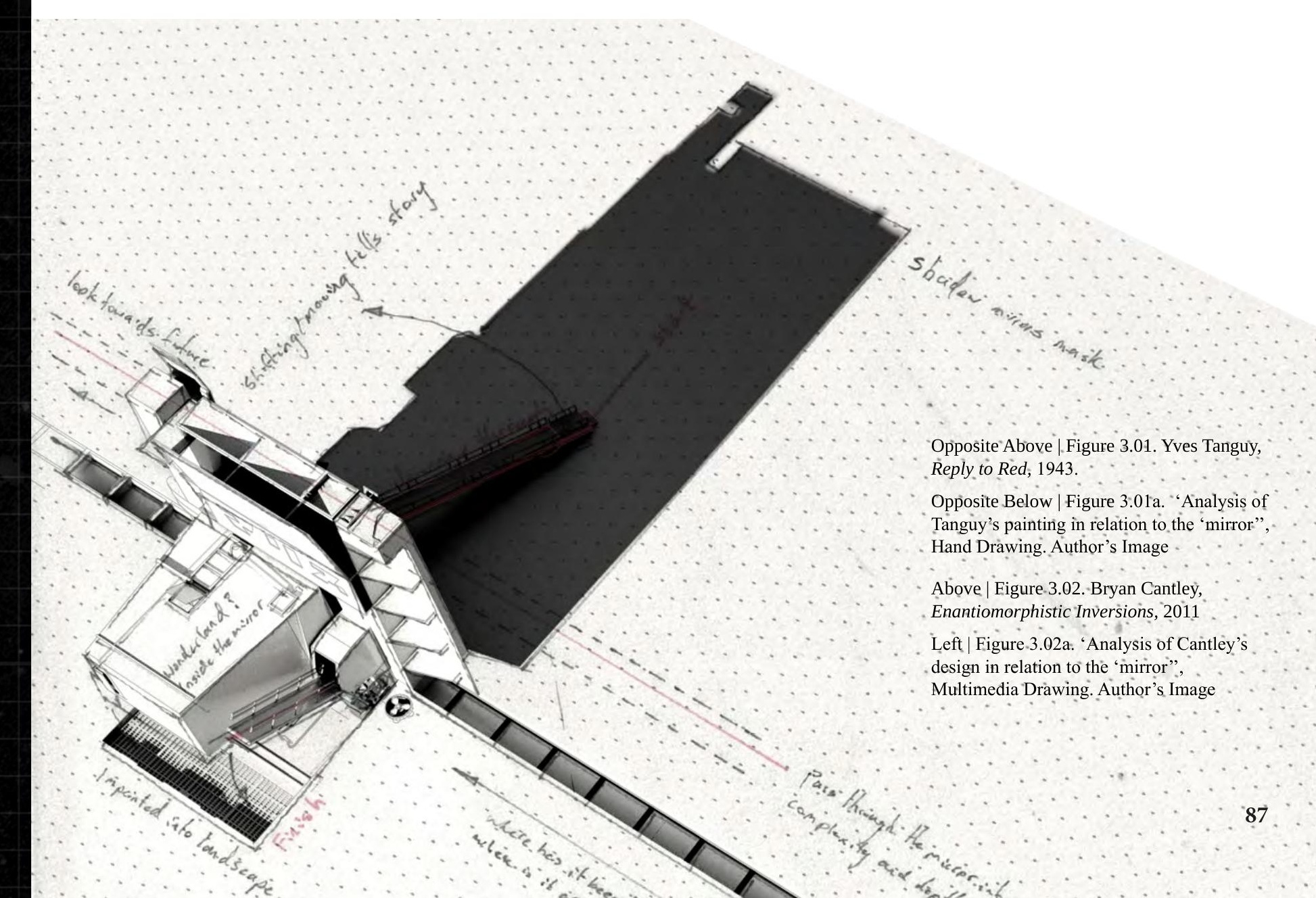



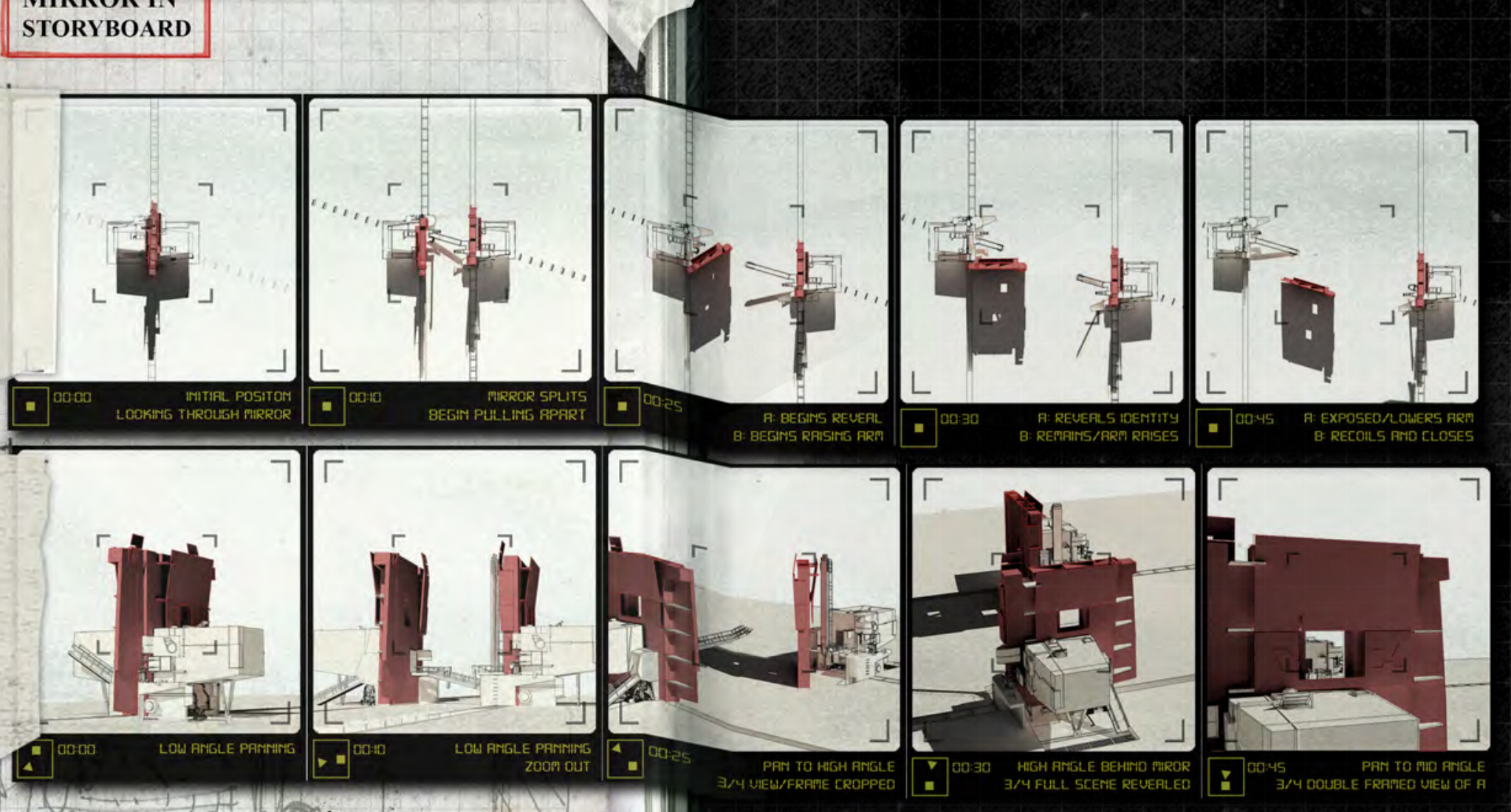

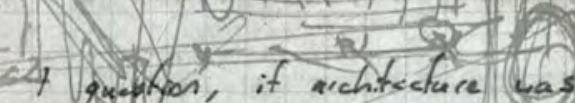

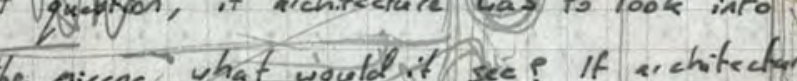
could ses itself. Wouble it be nore? Now I wender how might the miseres inspire. Now vonder how might the mirro or inspin itseffe is in fach architectane. A mask or facade which vithout nothing coudd exist mirros that procides a context to test my belicf of duality.
The mirror is, after all, a utopia, since it is a placeless place. In the mirror, I see myself there where I am not, in an unreal, virtual space that opens up behind the surface; I am over there, there where I am not, a sort of shadow that gives my own visibility to myself, that enables me to see myself there where I am absent: such is the utopia of the mirror.

- Michel Foucault, Of Other Spaces: Utopias and Heterotopias, p. 04.

Figure 3.02b places Cantley's Enantiomorphistic Inversions within a battle through the confrontation with its mirrored within a battle through the confrontation with its mirrored self. Red invite one to begin in to Red, invite one to begin interpreting the collsion. A timeline is provided suggesting the progress and journey that 
This content is unavailable.

Max Erst, Attirement of the Bride, 1949 .

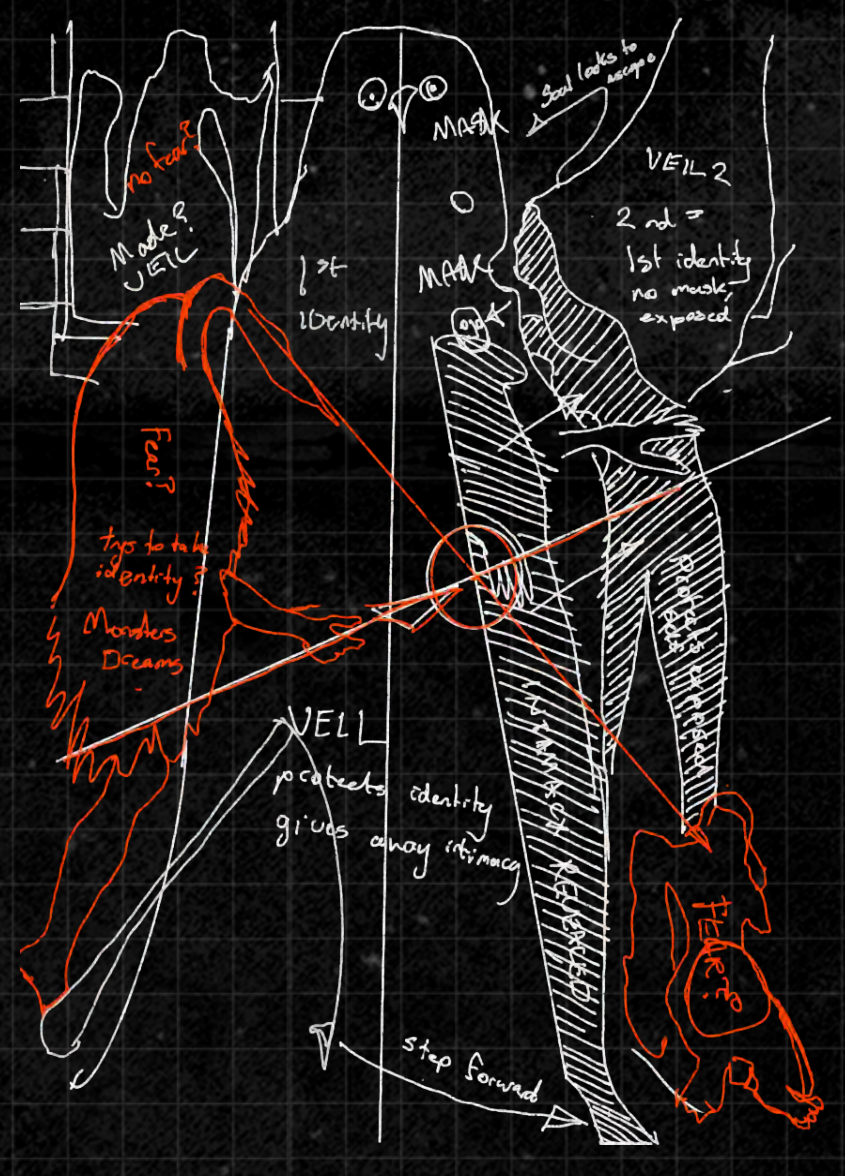

\section{ATTIREMENT OF THE BRIDE,}

MAX ERNST Max Ernst's Surrealist painting robe - masking and obscuring any form of identity, Attirement of the Bride (1949) while simultaneously exposing her most intimate

was selected as a case study that establishes a self. It appears as if she might have stepped 'confrontation' through the allegorical approach of forward and raised her hands to protect herself and 'the mask'. This painting depicts multiple figures the second figure, who could be considered as her in an architectural setting to express an inherent secret internal identity. This identity looks over her narrative. The main narrative involves the many shoulder towards the only way out. The two green identities of a bride on the day of her wedding. This figures quite literally personify and express the bride is covered almost completely by a veil and bride's fear surrounding her impending sacrament.

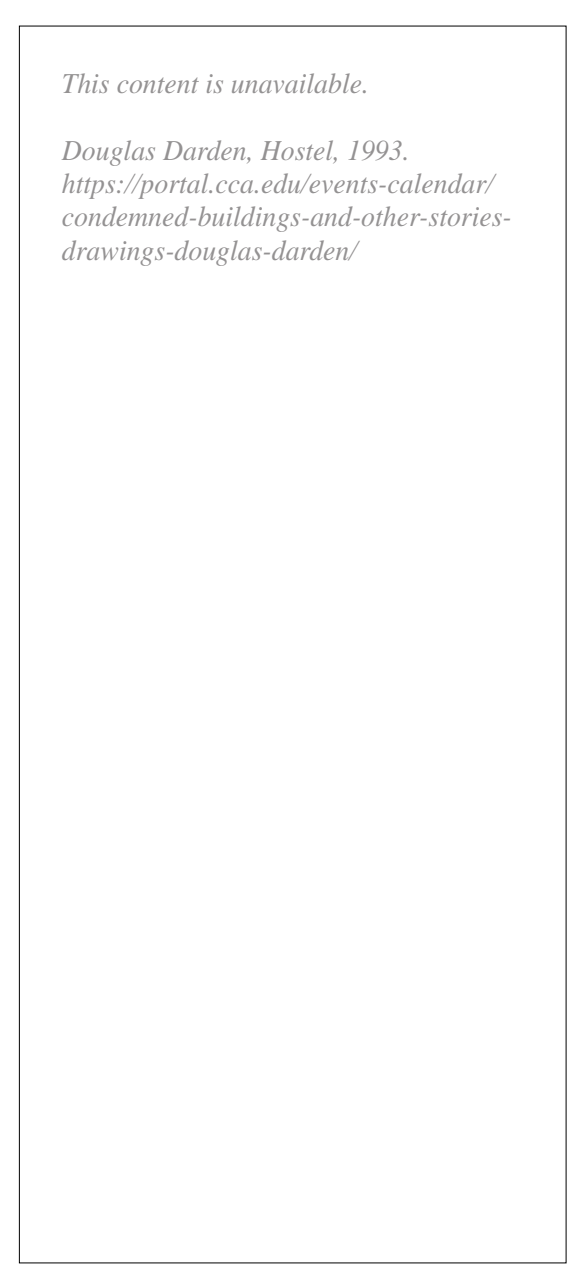

\section{HOSTEL,}

DOUGLAS DARDEN

Douglas

Darden's

design for Hostel (1993) was selected as an architectural case study that represents similar characteristics to those used by Ernst in Attirement of the Bride to establish the mask'. Designed as a temporary home for Nubian workers, the Hostel is a dynamic architecture, able to break at the center point, transporting workers to the Aswan Dam, and lowering them to the waterline (Darden, Condemned Buildings np). This case study was interpreted as two sides of self, where one side wears a mask similarly to the robe of the Bride in Ernst's painting. The stationary half of the hostel can be seen as a parallel Ernst's Bride, while the dynamic half is the equivalent of her secret identity - free to move yet connected through 'soul'

Opposite Left | Figure 3.03. Max Ernst, Bride, 1949 Opposite Right | Figure 3.03a. 'Analysis of Ernst's painting in relation to the
'mask", Hand Drawing. Author's Image Above | Figure 3.04. Douglas Darden,

Right | Figure 3.04a. "Analysis of
Darden's design in relation to the

"mask", Multimedia Drawing. Author's
Image

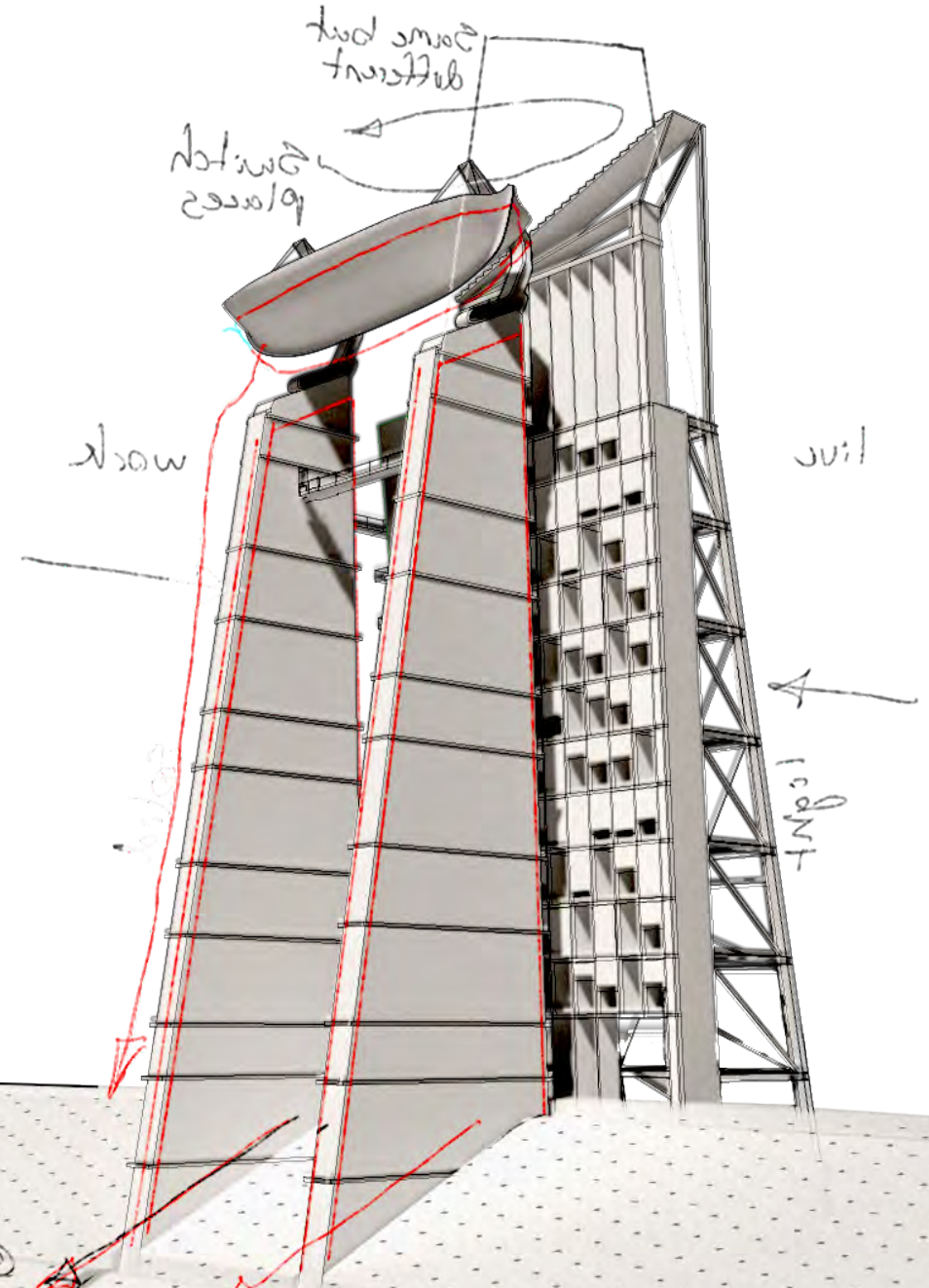


ARI' The Athrement of the Binde
ARC' Hosster.

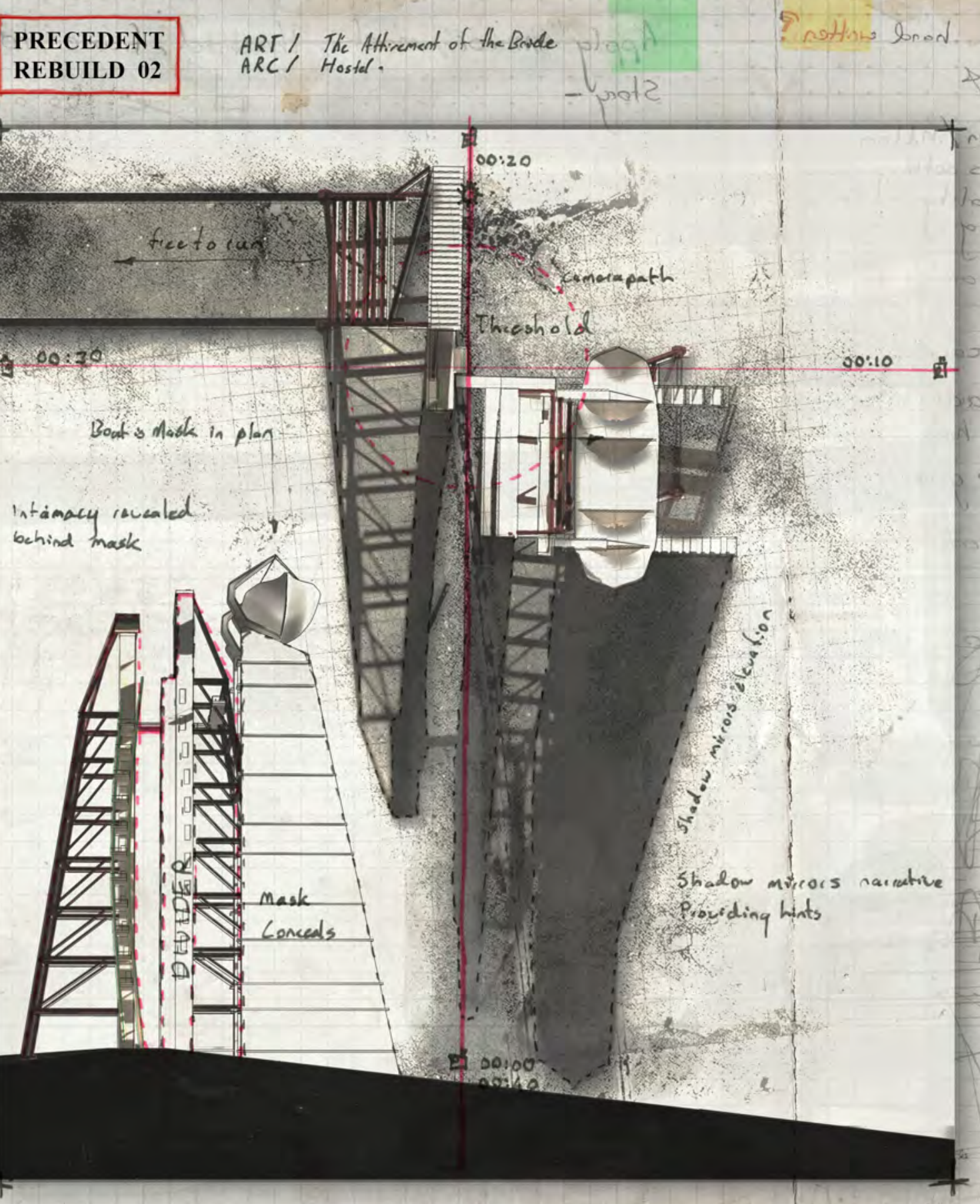

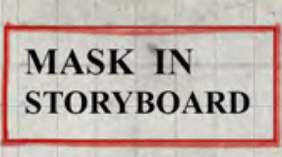

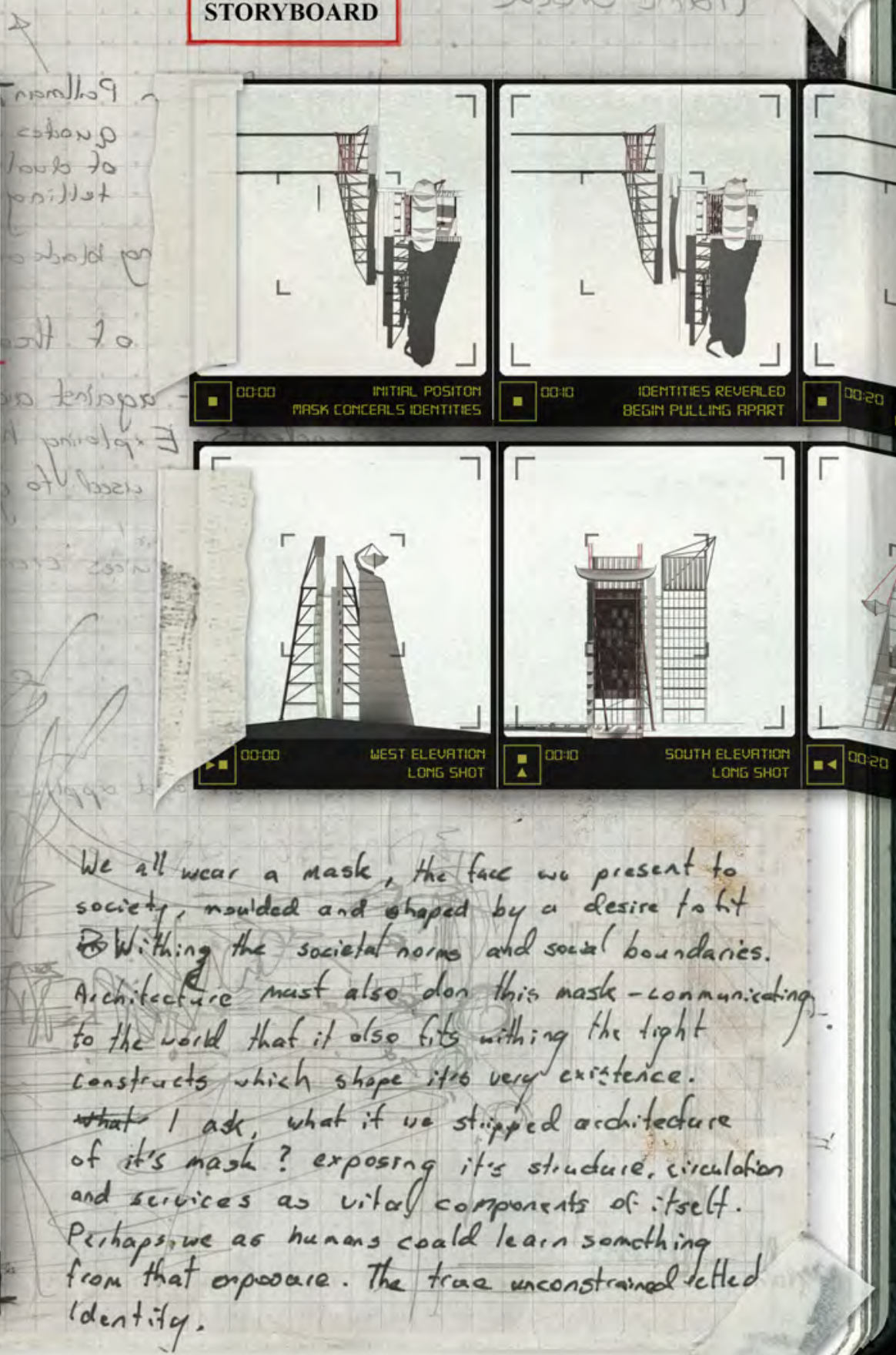

.
Author's Image 


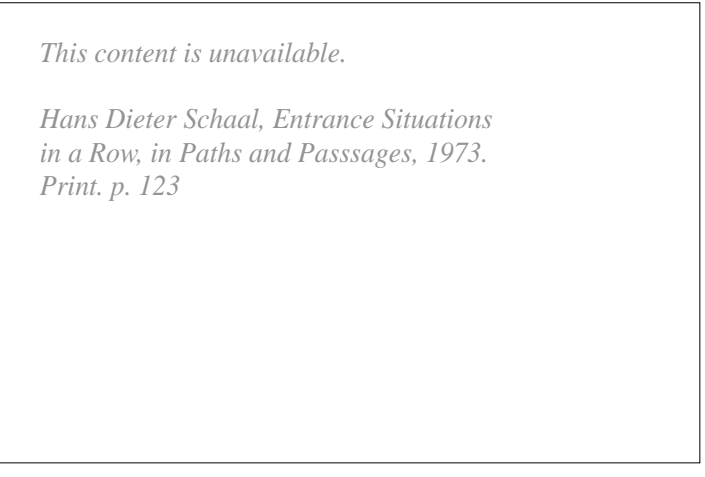

Opposite Left IFigure 3.05. Georgio de Chirico,
The Soothsayer's Recompense, 1913 . The soothayeris necompense, 191 .

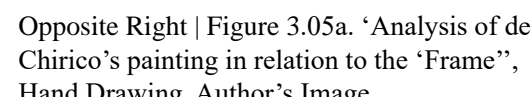

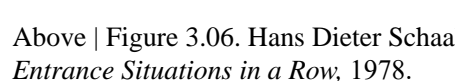
Below | Figure 3.06a.' 'Analysis of Dieter Schal' sesesgn in relation to the 'frame"
Multimedia Drawing. Author's Image
ENTRANCE SITUATIONS IN A ROW,

HANS DIETER SCHAAL

Hans Dieter Schaal's design for Entrance Situation in a Row (1978) was selected as an architectura case study that represents similar characteristic to those used by de Chirico in The Soothsayer's Recompense to establish the 'frame'. This example was interpreted as an architectural variation of De Chirico's painting, where the viewer does not remain in one point, but moves through the various framing devices in a process of transition. The confrontation exists between the beginning and the end, with the future being framed as one walks along the path, and the past being framed as they return back along it.

\section{THE SOOTHSAYER'S RECOMPENSE,} GIORGIO DE CHIRICO

\section{Georgio}

Chirico's Surreal

painting The Soothsayer's Recompense (1913) was selected as a case study that establishes a 'confrontation' through the allegorical approach of 'the frame'. In this painting four quadrants
formed by architectural subject matter divide the formed by architectural subject matter divide the painting through its geometric center - providing both a space and a place for the narrative to b experienced and understood. Each quadrant can be interpreted individually as important pieces of the holistic narrative. In the top left quadrant, the shaded architecture provides three gateways int
the darkness and with it the unknown; a clock the center of the gable suggests the importan of time for understanding this painting. The lower left quadrant depicts a statue that might represent the Soothsayer. This figure appears to have twisted to look towards what we cannot see and once again what we cannot know. The lower left quadrant frames a view through architecture where dark shadows provide perspective while also determining the sun's position off the edge of the canvas. The upper right quadrant provides the only proof that time is moving. It frames two trees in the distance, the only sign of natural life. To the left a train is framed in the smaller central segment by a brick wall - a futuristic contrast to its classical counterparts - a cloud of smoke hints at its swift movement, undetected by the Soothsayer.

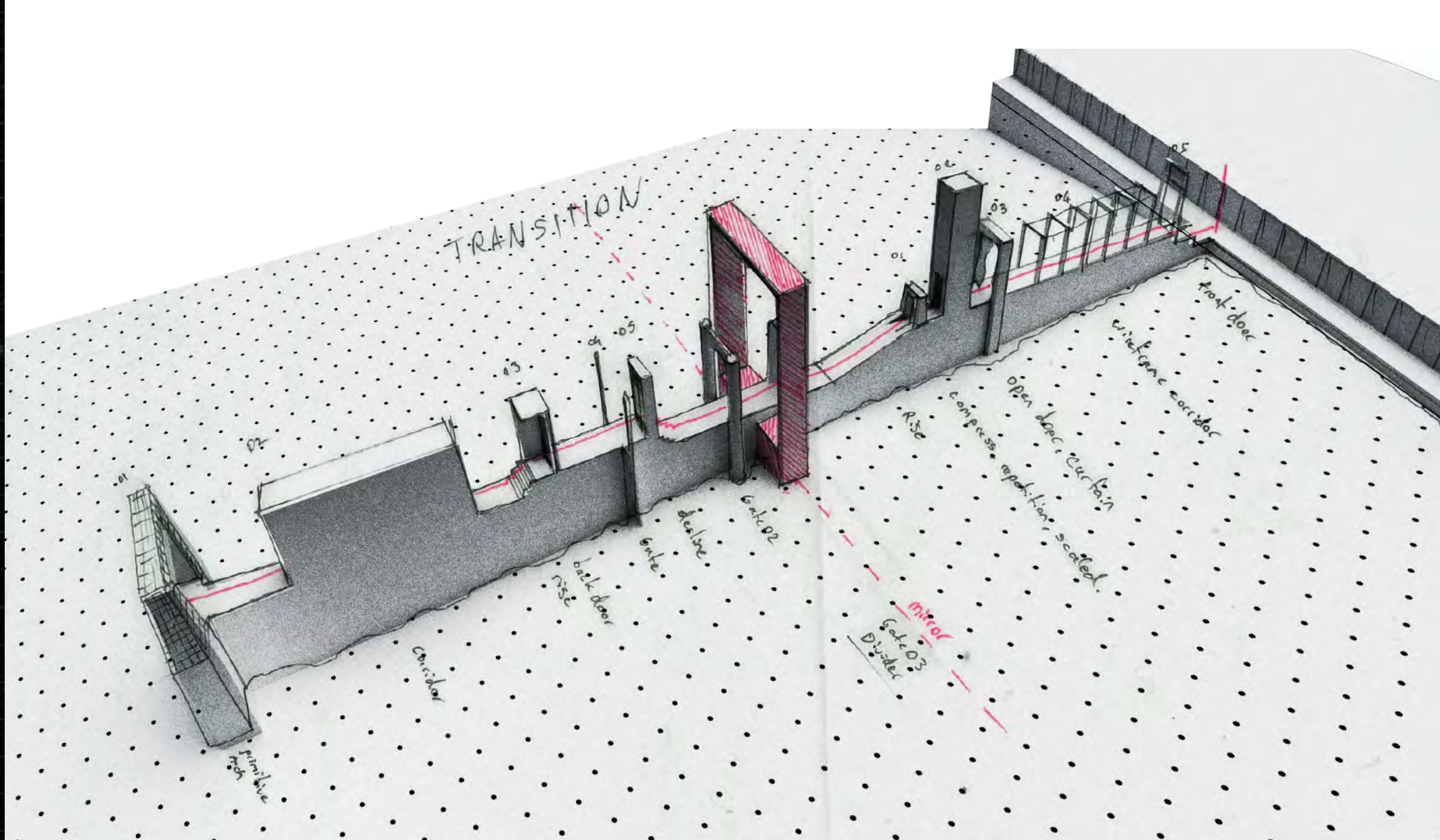



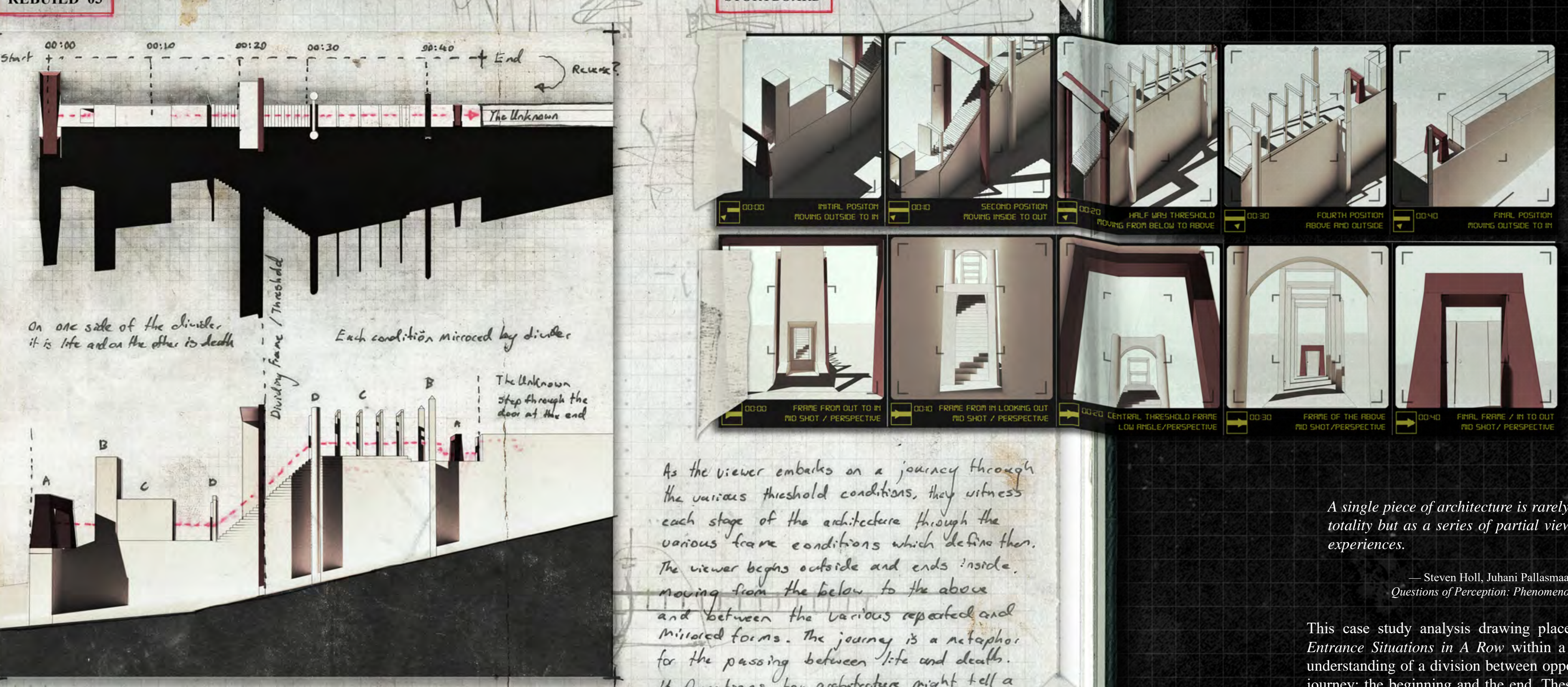

As the viewer embarks on a journcy throxgh

the various threshold conditions, they witness

each stage of the ardhitceture through the

various frame eonditions which define the

The viewer beogns outside and ends inside.

mouing from the below to the aboue

and between the various reperfed and

mirrored forms. The jeurny is a metapho

It Pureotrons how archetectere might tell a

ofory through the expetution of crifical elemet

A single piece of architecture is rarely experienced in its totality but as a series of partial views and synthesised experiences.

- Steven Holl, Juhani Pallasmaa, Alberto Pérez-Gómez,
Questions of Perception: Phenomenology of Architecture. n.P

This case study analysis drawing places Dieter Schaal's This case study understinding of a division between opposing points of the journey: the beginning and the end. These points represent the confrontition, while the transitional space between then represents the progress or journey one must embark upon in order to understand the nature of the confrontation. 


\section{This conerentis manvailable}

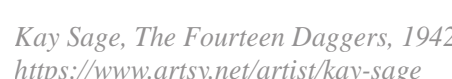

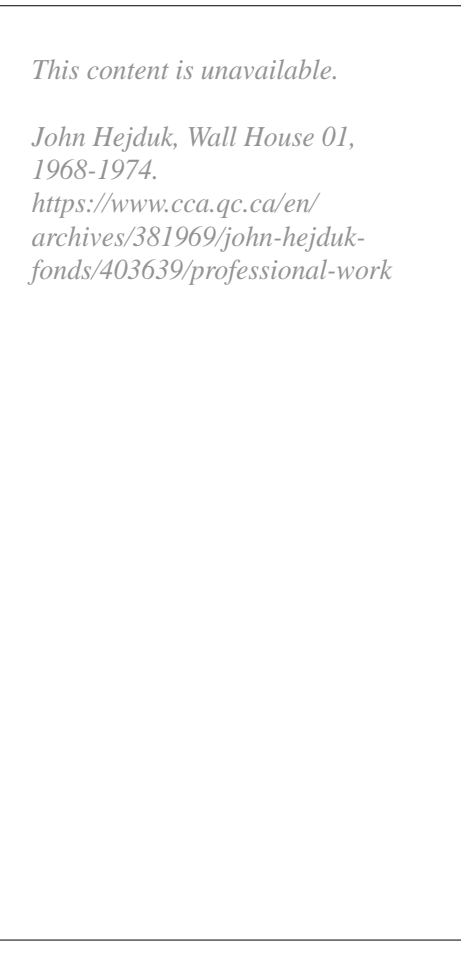

Opposite Left | Figure 3.07. Kay
The Fourteen Daggers, 1942.

Opposite Right | Figure 3.07a. "Analysis of

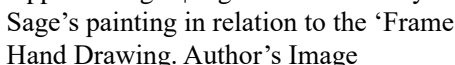

Above | Figure 3.08. John Hejduk

Below | Figure 3.08a. 'Analysis of

Multimedia Drawing. Author's Image
WALL HOUSE OT,

JOHN HEJDUK Wall House 01 (1968-1974) was selected as an architectural case study tha represents similar characteristics to those used by Sage in The Fourteen Daggers to establish the interpreted as an architectural response to Sage's painting, where the enclosed private side represents the indoors and the exposed circulation space represents the indoors. The threshold wall signifies the pivotal point of the confrontation, allowing one to pass through, while maintaining a defined separation of each identity.

\section{THE FOURTEEN DAGGERS}

\section{KAY SAGE}

Kay Sage's Surrealist painting through its center. One appears to be standing The Fourteen Daggers (1942) tall as they walk towards the light; the other was selected as a case study that establishes a remains behind-watching with an expression 'confrontation' through the allegorical approach of longingness or distress. This solid threshold of 'the threshold. Two figures stand in a clear becomes the architectural divider of duality, opposition: one dark and inside and one light and separating inside from the outside; light from the outside. They are divided-occupying both sides shadow; public from the private and perhaps even of the solid boundary. A large red door hangs open the living from the dead. It represents a place in allowing us to see through the threshold and into space through which one passes and in doing so the realm beyond. A stark contrast between the two changes everything figures' scales and attitudes divides the painting

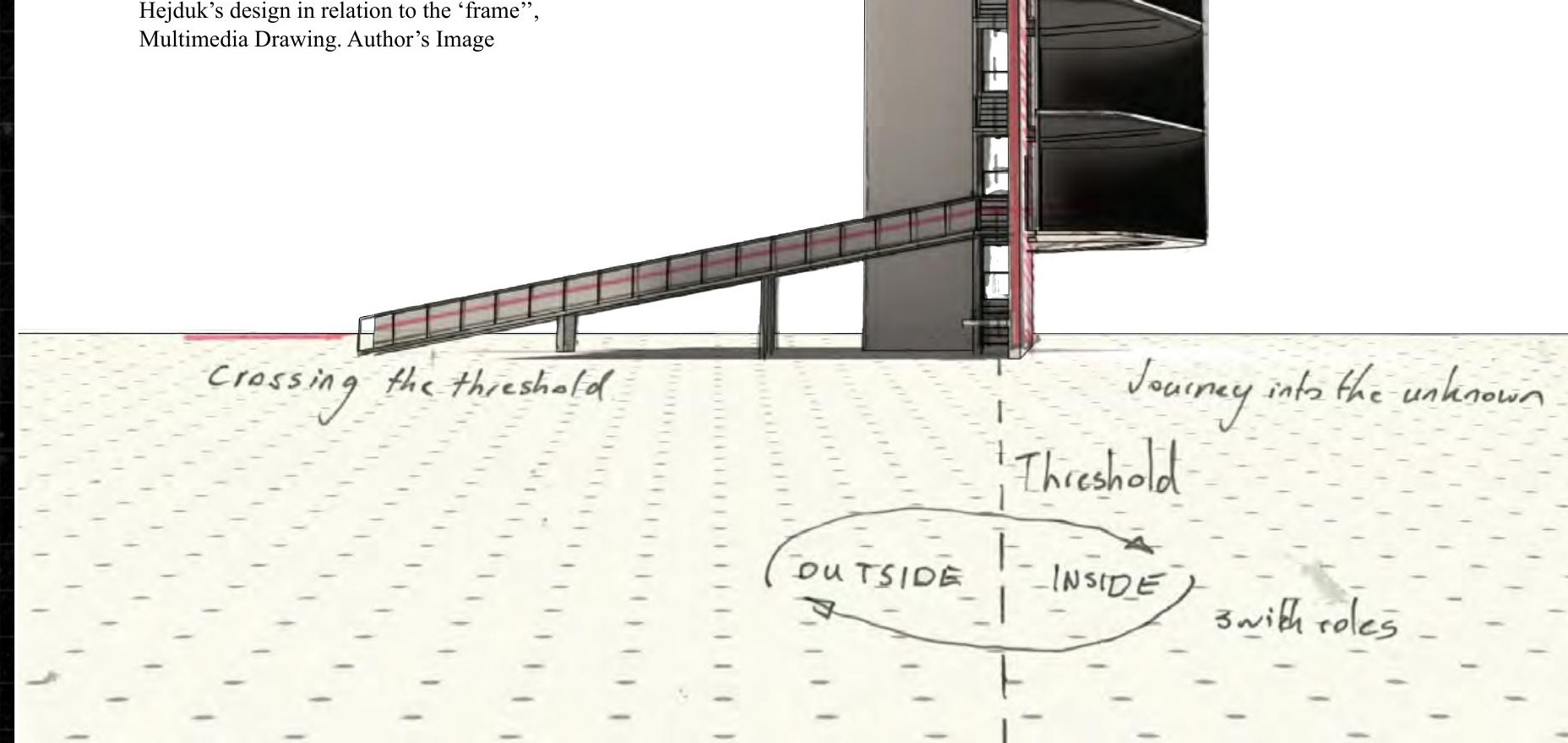




\begin{tabular}{|l|l|}
\hline PRECEDENT & ART / The Fourtean Oagge's \\
REBUILD 04 & ARC / Wall House OL
\end{tabular}
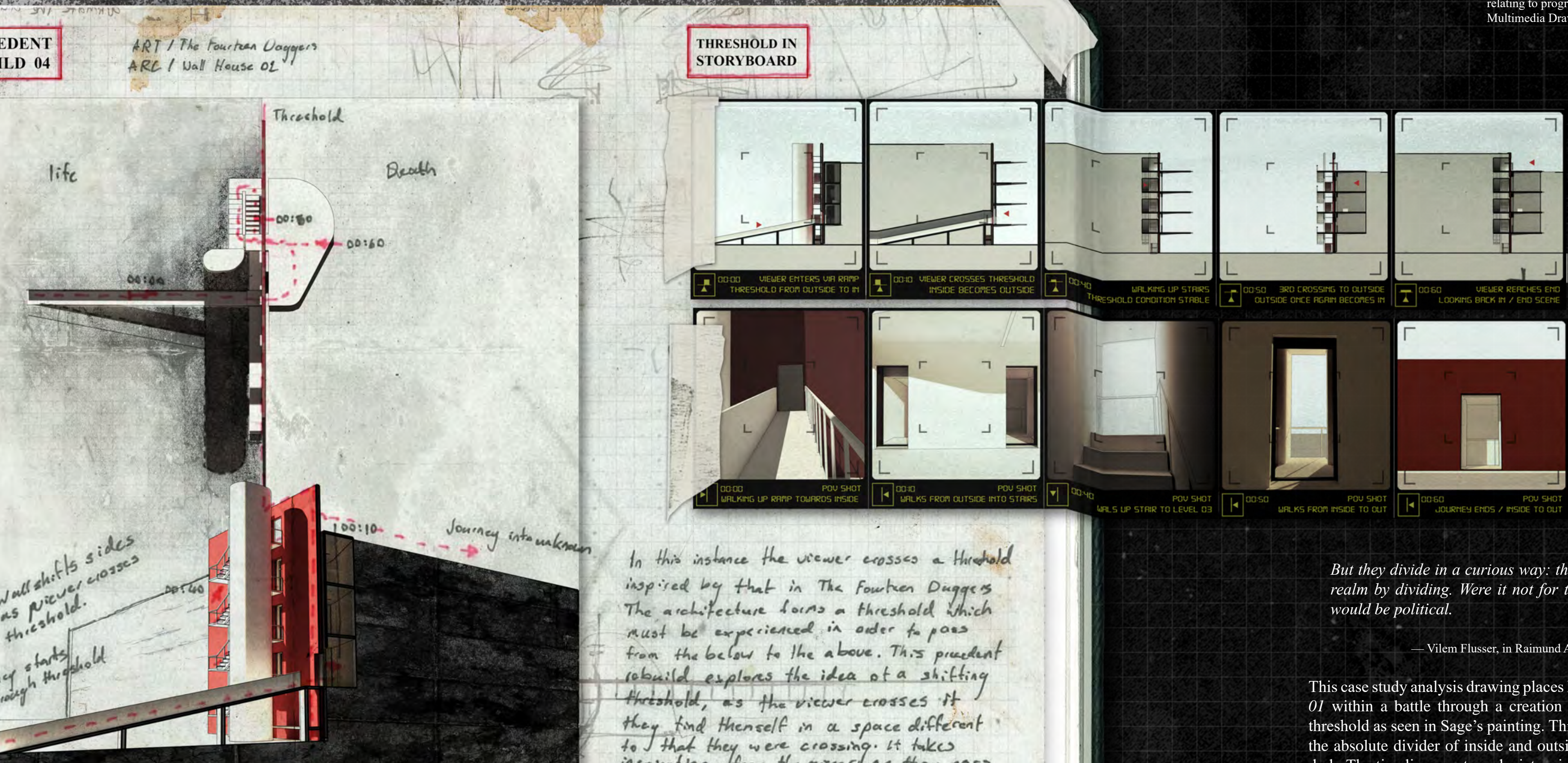

In this instance the viewer crosscos a thesoldd ingpired by that in The founten Duggrs

The archifecture forns a threshold which

nust be expscienced in onder to pass

from the below to the a bove. This precedent rebuild exploces the idea of a shifting throshold, as the viewer crosses it they tind thenself in a space different to that they were crossing. It takes inspination fiom the mircing. as they pass from leside to the outside which then becond once a arain inside, itselft.
But they divide in a curious way: they create the private realm by dividing. Were it not for the walls, everything would be political.

-Vilem Flusser, in Raimund Abraham [Un]Built. p. 166

This case study analysis drawing places Hejduk's Wall House

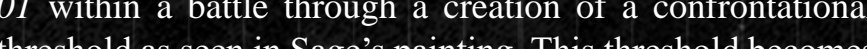
the absolute divider of inside and outside, the light and the dark. The timeline mo of the threshold to the other through the access routes of the building In this progress, Inside and Outside are redf the each time the threshold is crossed, exploring the duatiy 


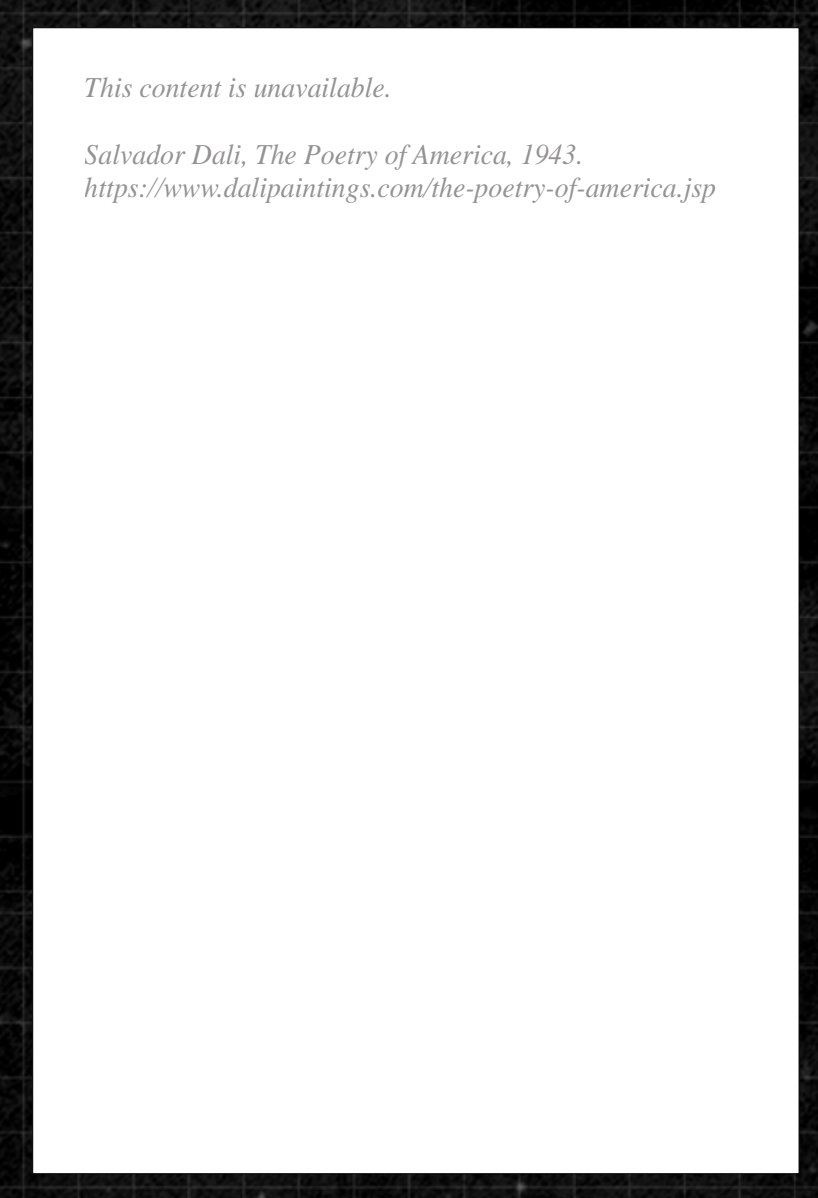

\section{THE POETRY OF AMERICA}

SALVADOR DALI Salvador Dali's Surrealist the painting that begins to suggest what it might painting The Poetry represent. A dance seems a fitting description as of America (1943) the right figure raises his arms and faces the viewer was selected as a case study that establishes a revealing his body; the left figure protects itself confrontation through the allegorical approach of with one arm and turns away from the viewer the dance. The two foremost figures in this painting concealing his identity. The left figure appears to divide this otherwise symmetrical composition be also concealed further by shadow, whereas the directly through its centerline, creating a threshold right figure is further exposed by the direction of between, yet not touching. The monolithic the light. The surreal objects symbols and smaller architecture punctuates this division, introducing characters begin to develop on these dualities of the depth to the landscape allowing it to be understood dance. A small box on the left figure's hip appears as three-dimensional space, as opposed to just a pulled open-revealing his secrets to the onlooking two-dimensional image. Each figure appears to right figure. The candle that sits within the bright represent the opposing figure's dual nature, as figures head symbolises light, whilst simultaneously they interact in opposition through a complex rendering the figure anonymous.

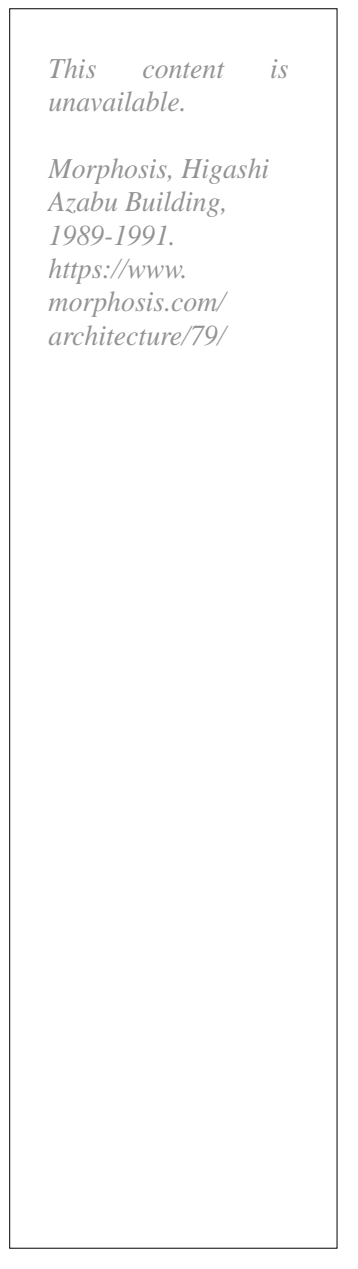

Opposite Above | Figure 3.09. Salvador
Dali, The Poetry of America, 1943. Opposite Below | Figure 3.09a. 'Analysis
of Dali's painting in relation to the
'dance", Hand Drawing. Author's Image Above | Figure 3.10. Morphosis, Higashi

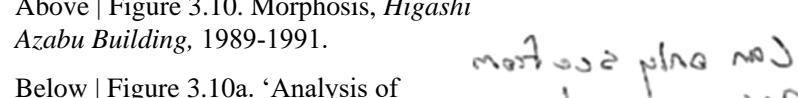
Morphosis's design in relation to the "frame", Multimedia Drawing. Author's

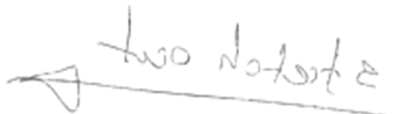

HIGASHI AZABU BUILDING

MORPHOSIS Morphosis's design for the Morphosis's design for the
Higashi Azabu Building Higashi Azabu Building (1989-1991) in Tokyo was selected as an architectural case study that represents similar characteristics to those used by Dall in The Poetry of America to establish the 'dance'. With its clear differentiation between two interconnected halves, the design could be interpreted as the two characters in Dali's painting, where each side shares dimensions and spatial relationships, yet one appears to turn its back, while the other looks onward.
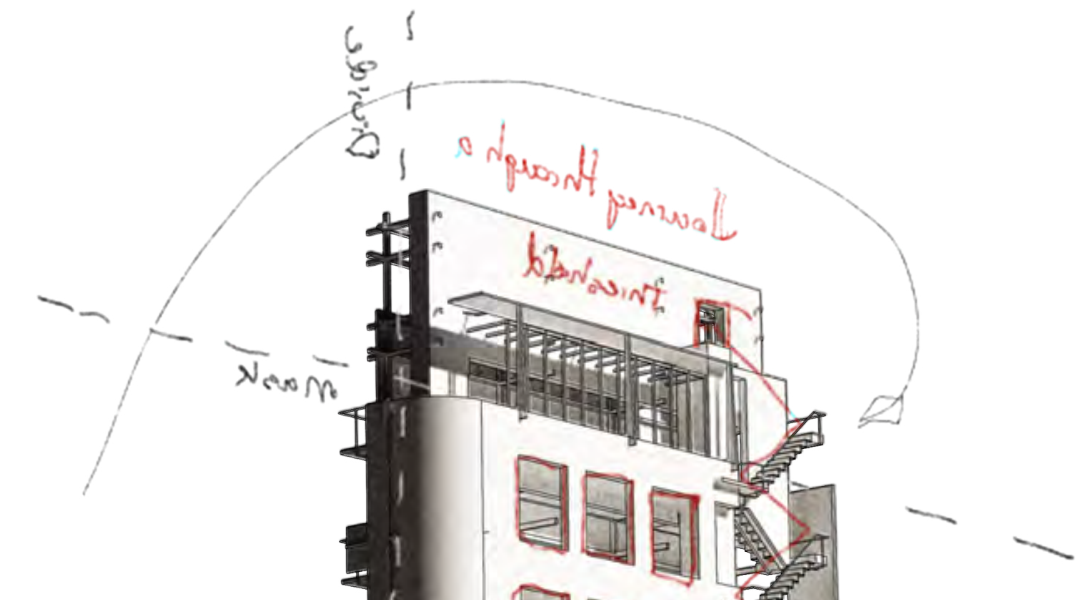

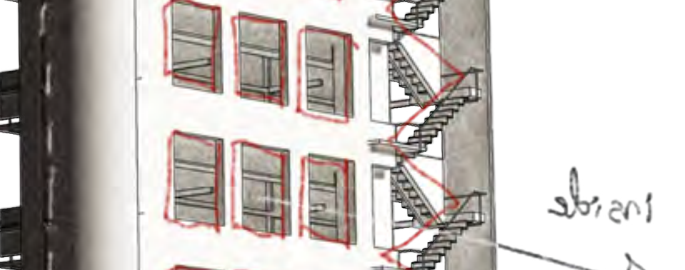
프. . a 17 


$$
\text { ARC1 > Higashi Asabu Bailding. }
$$

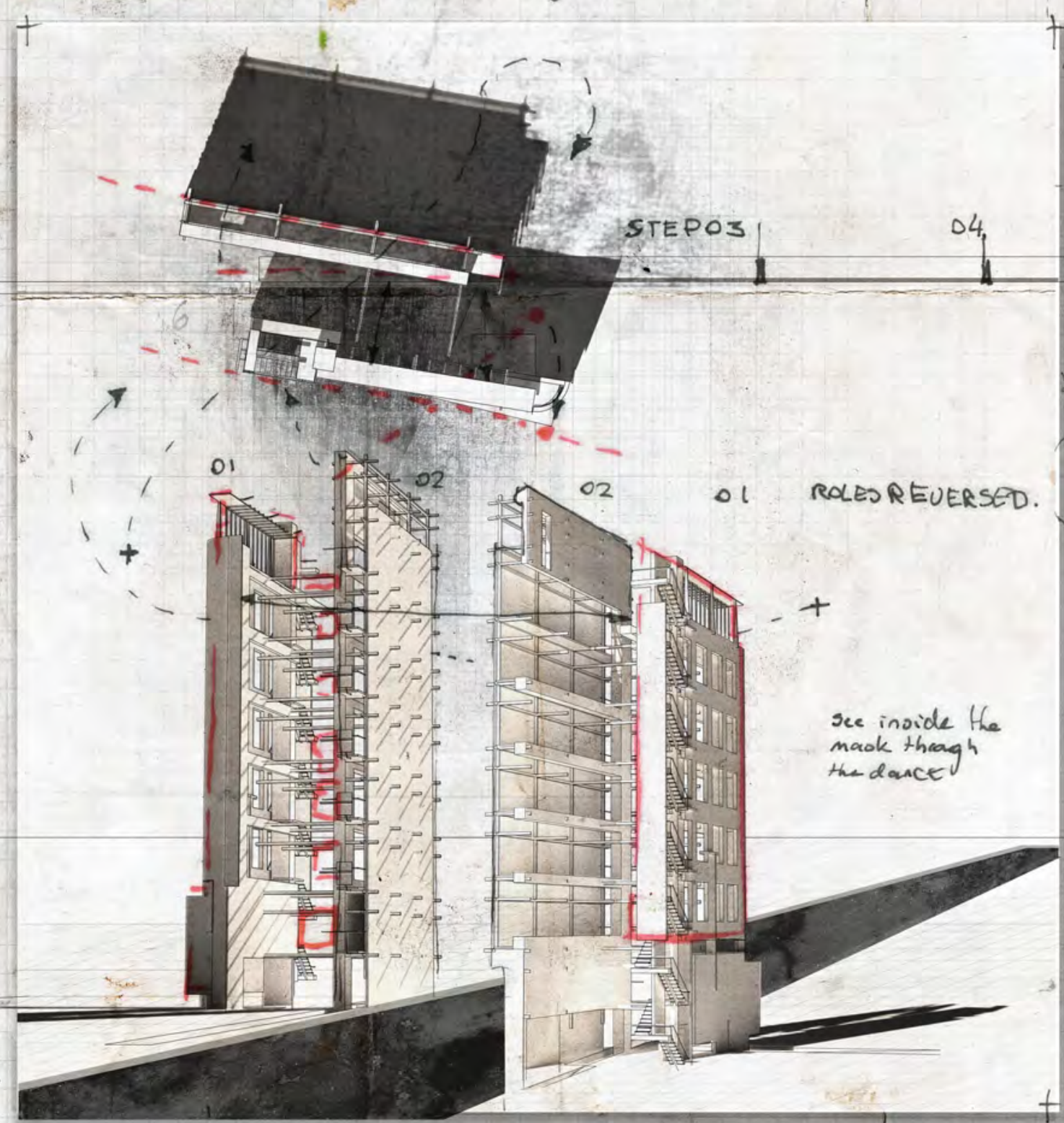

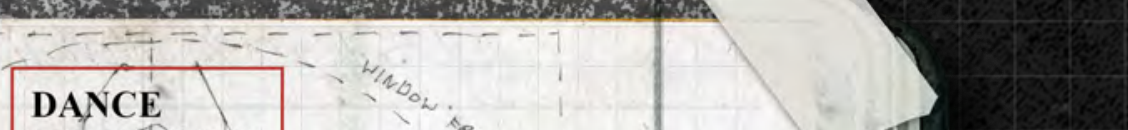

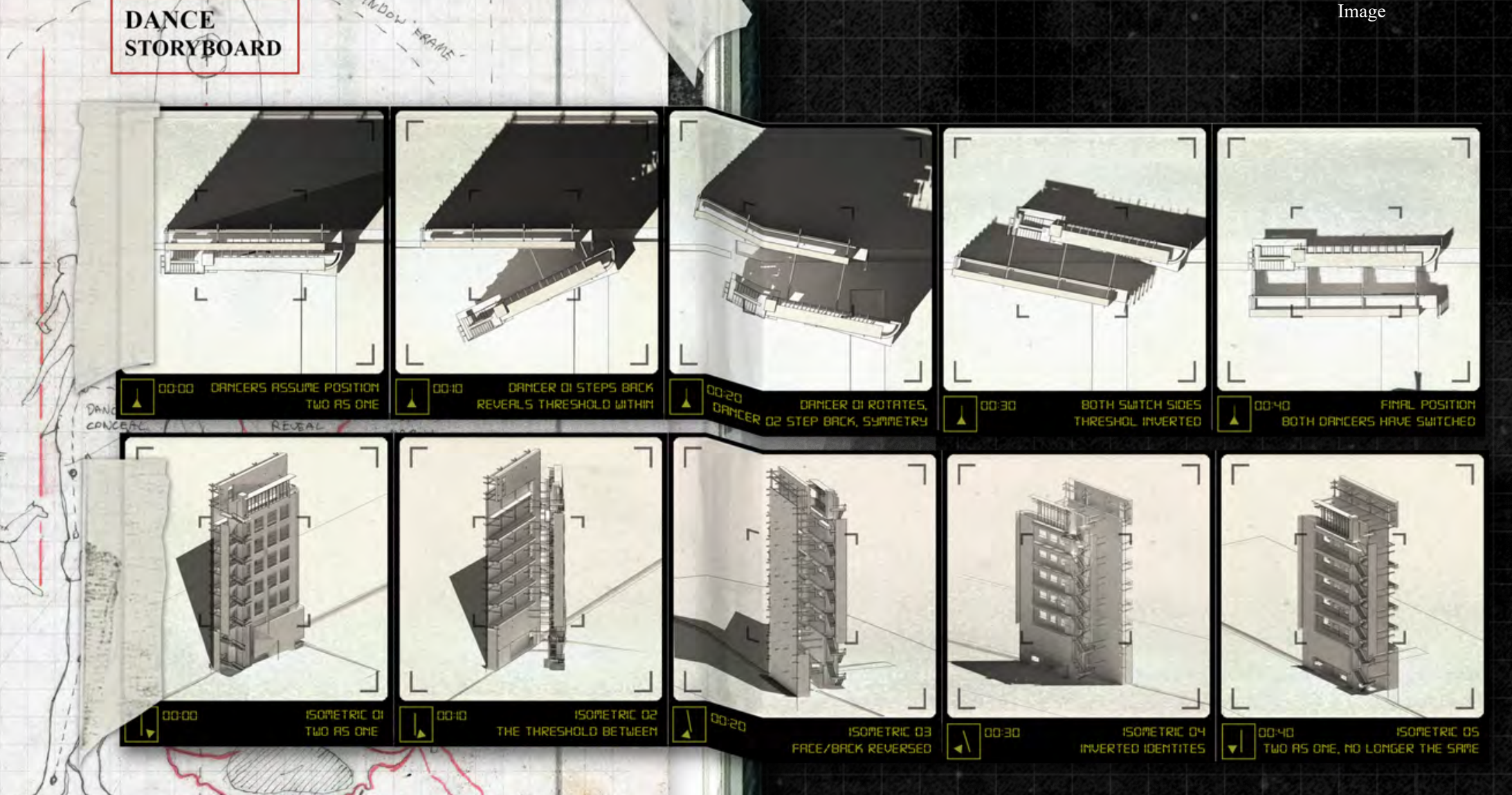

The Dance is the eatmination of the ibattle', it is the action from start to finish. Where shifting confrontations move fhrough a 'sequenca of steps. The Dance allows ore to witness both sides of seff einadtansausly. One from over the shouider. one idirectly in the face. Th.s Darice becomes the figarestice geometry of an allegoical languge.
Time-based sensitivities are mixed in the cauldron of by dimensions of by the pragmatics of

-Neil Spiller. “Future Fantasticals" in Drawing Futures: Speculations in
Contemporary Drawing for Art and Architecture, p. 170.

This case study analysis creates an allegorical battle through division of the two sides of Morphosis's Higashi Azabu Building-reimagined as the two figures in Dali's painting. This battle defines an architectural confrontation through the shifting variations of the two 'dancing' entities. The Dance itself is fundamentally temporal, understood through the 'progress' steps that lead to the current position in the allegorical journey. 
The tools and means we employ as architects generate a certain 'signature'. These signs and identifying codes may be read by the observer and perhaps interpreted in ways considered by the authors. The tools themselves are, however, mute, often discarded. Devices that serve and yet disappear. In some way to remedy the situation, and experiment with hidden possibitites, we identify with sensibities, which are, by theoretical proclivities, philosophical leaning etc, embedded in the work. Evidence of the manufacturing processes will be manifested in the determined result of the building.

\author{
西
}

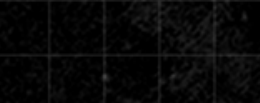



味: 吅
Within architecture, then, the notion of site might be similarly broadened by thinking of it as a fundamental part of the design and building process. to conceive the sile as "constructed" is to challenge its given, immutable

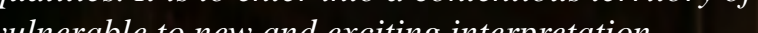

- Martin Hogue, "The Site as Project, Lessons from Land Art and Conceptual Art", p. 54.

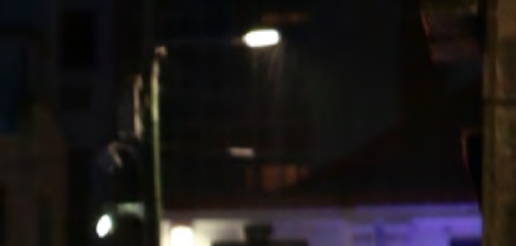

5
3.2.1 THE SEVERED SITE

This thesis investigation asks:

How can urban architecture help to reawaken the transformative heritage stories that form place identity, enabling architecture as well as its inhabitants

The thesis investigates the disconnection between architecture and the heritage stories that give place identity to the land it occupies. This disconnection exists particularly within the urban realm, where tight adjacencies and high-density placements make it problematic for the architect to establish an independent identity unique to a specific site. In his article "The Site as Project, Lessons from Land Art and Conceptual Art", Martin Hogue argues for a reconsideration of the relationships between site and project, discussing various precedent examples where site has been fundamental to project From his analysis of the selected works, Hogue presents an argument for engaging site and project simultaneously. He argues that typically it is not site or architecture alone that lacks specificity but rather it is the dialectic relationship between the two (Hogue, 60). He suggests that the architect must challenge traditional presumptions of site in order to open the imagination to new realms of opportunity - where site is thought of, not as an empty lot awaiting building, but rather as a prospect for intervention, a significant componen in the formation of an architectural outcome.

When site and project are construed as elements of a dialectic, we are freed to reexamine and or reenergize the relationship one shares with the other.

$$
\begin{aligned}
& \text { - Martin Hogue, "The Site as Project, Lessons from } \\
& \text { Land Art and Conceptual Art", p. } 54 .
\end{aligned}
$$

The thesis research engages Hogue's notion of site dialectics, implementing 'site' and 'project' as the two fundamental forces engaged within he developing allegorical 'battle'. Hogue's clear division of site and project, and his understandin of the dialectic relationship between them is interpreted as a mirroring of Pullman's demonwhere site and project (architectural intervention) share similarities to the dialectics between the inner and outer self. The thesis uses Hogue's premise to bild further upon Abrahem's theories providing a fundamental link in the allegorica chin, siting the allegorical confromtation within he research context, and in doing so, revealing new pportunities for contextual interpretation. 


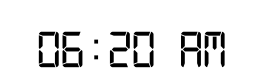

\subsubsection{THE TRANSITIONAL SITE}

“On Site: Architectural Preoccupations”, Carol J. Burns argues that "site is frequently understood as a synchronic phenomenon, irrevocably divorced from other times" (Burns, 149). She suggests that simply as the forces that have shaped its present visible form, and thus the heritage that goes beyond this visual form is lost to the intangible realm of this visual
memory.

The site as received is never cleared or empty; indeed, it is not possible for the architect to clea the site of its own constituent formal content.... The site is a work, a human or social trace. It is comparable to a myth, temple, or city in that it is open to archaeological deciphering. Carol J. Burns, "On Site: Architectural Preoccupations,",
in Andrea Kahn, ed., Drawing, Building, Texti Essayss in
Architectural Theory p. 164.

Burns suggests that any site, prior to architectural intervention, is already a work in itself, a significative system with no single author. And that to detach the building from this site, whether through clearing or constructing over, is to suppress the political, ideological and temporal potential of the architecture (Burns, 164). Therefore, Burns the architecture (Burns, 164). Therefore, Burges
suggests an alternative method for engaging suggests an alternative method for engaging
site in design, a way that embraces its temporal Aro, Wellington, 1846, showin Manne

Yet another possibility is to investigate the existing situation-building, city or native land-to discover its latent qualities or potential, inherent conditions can motivate the ensuing construction so that the new participates within the existing. This allows both a criticism and a release from the received conditions and reciprocally, a reverberation of them so that the boundaries between the conditions as received and renovated become blurred; both may be productive because both are aggressive with respect to each other.

- Carol J. Burns, “On Site: Architectural Preoccupations,"
in Andrea Kahn, ed., Drawing, Bulilding, Text: Essays in
Architecturac Theory p. 155.

In response to Burns's argument, the following contextual analysis attempts to delve beyond a raditional understanding of the site as cleared constructed, interrogating the much broader historical context in relation to major social, nvironmental and political shifts that have shaped the present Te Aro Park. This provides a foundatio of transformative heritage stories, which together orm a basis for a temporal place identity. These eritage stories become the foundation of the llegorical 'progress' while simultaneously opposing elements of the allegorical 'battle', where major contextual shifts are embodied symbolically within the designed outcomes. 


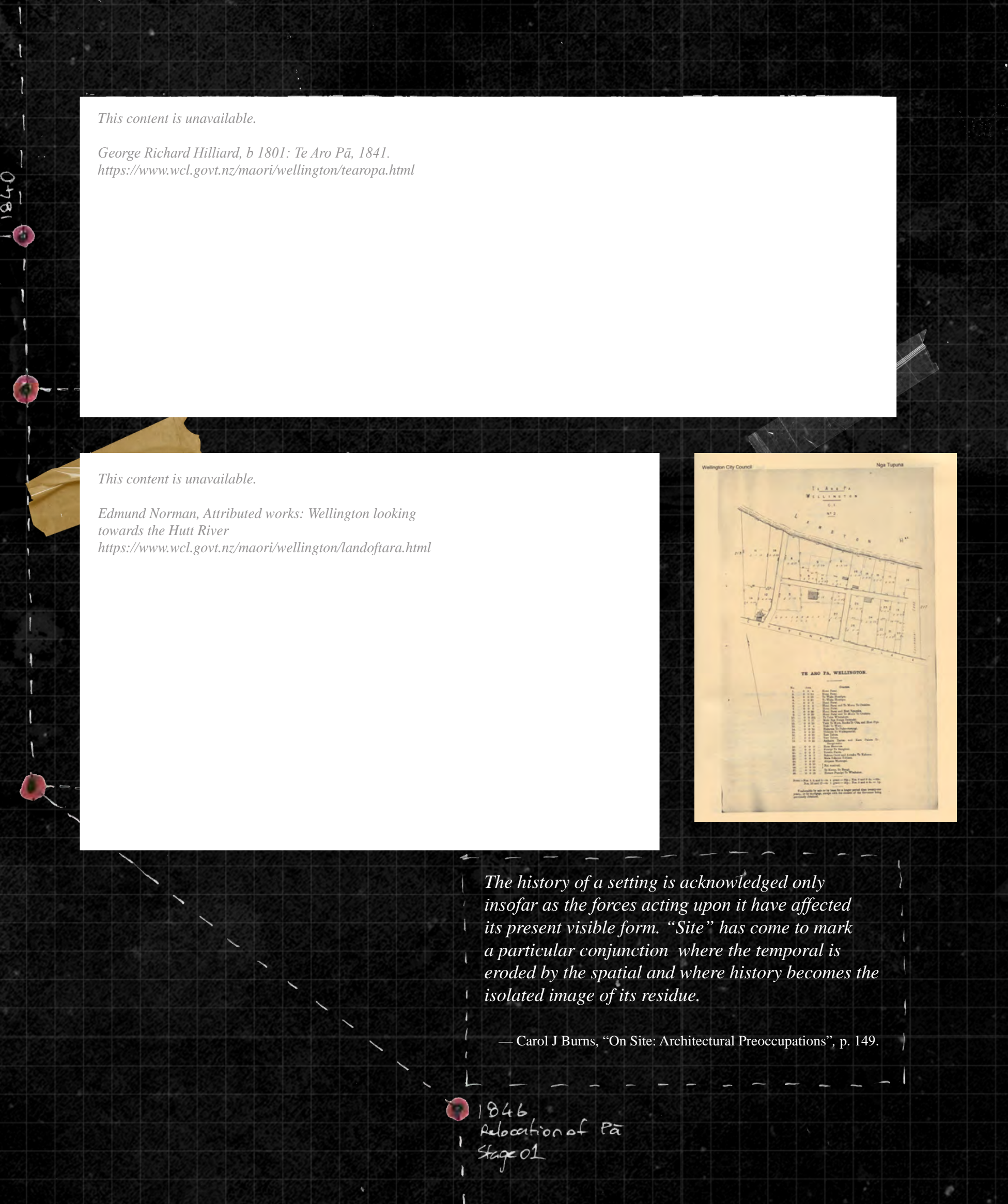

吅: 吅 唡

3.2.3 HISTORICAL CONTEXT The site for ed research is the urban area in this designAro Park, located in central Wellington, and previously the site of Te Aro Pā. This site has undergone multiple transformations over its history, with drastic changes occurring alongside the development of the city center. The site was selected for the rich inherent heritage context, at risk of being lost beneath the layers of urban development.

Before human settlement, the shoreline of Wellington Harbour was mainly characterised by flat swampland covered in toi toi, raupo and flax. The Waimapihi Stream flowed through the flats providing valuable food and water and a thriving ecosystem to sustain human civilisation. In the $1820 \mathrm{~s}$, the people of Ngāti Ruanui and the wider Taranaki region established Te Aro Pā along the southern harbour edge, subsisting on the abundance of the landscape In 1839, when Colonel William Wakefield's ship Tory sailed into Wellington Harbour, the pā encompassed about 5 acres $(20,000 \mathrm{sm})$ of the foreshore (Menzies, 2). Land was given within the $\mathrm{p} \overline{\mathrm{a}}$ for missionaries to Opposite Above | Figure 3.15. "1841 Drawing Developing Wellington settement'. ') Amongs Opposite Below Left | Figure 3.16. 'Wellington
Looking Towards the Hutt, 1842 (arrow indicates

Opposite Below Right | Figure 3.17، “'Te Aro Pā Survey Map, an Attempt to Begin Subdividing the Pä.' https://www.wcl.govt.nz/maori/wellington/ (seen in fig. 3.15).

When the European settlement in Petone failed, settlers moved to the Te Aro flats and began expanding around the $p \bar{a}$. In 1846, with racial tensions heightening Governor Grey controversilly relocated a large majority of the Māori population - reducing the $\mathrm{p} \overline{\mathrm{a}}$ to a shadow of it for polf while the developing aity quick Above | Figure 3.18’ Te Aro pā Survey Map, Image). 
'Looking East, down Courtenay Place from the tip of what was formerly known as
Pigeon Park', 1928. https://wellington.
recollect

1 recollect.co.nz/nodes/view/510?keywords

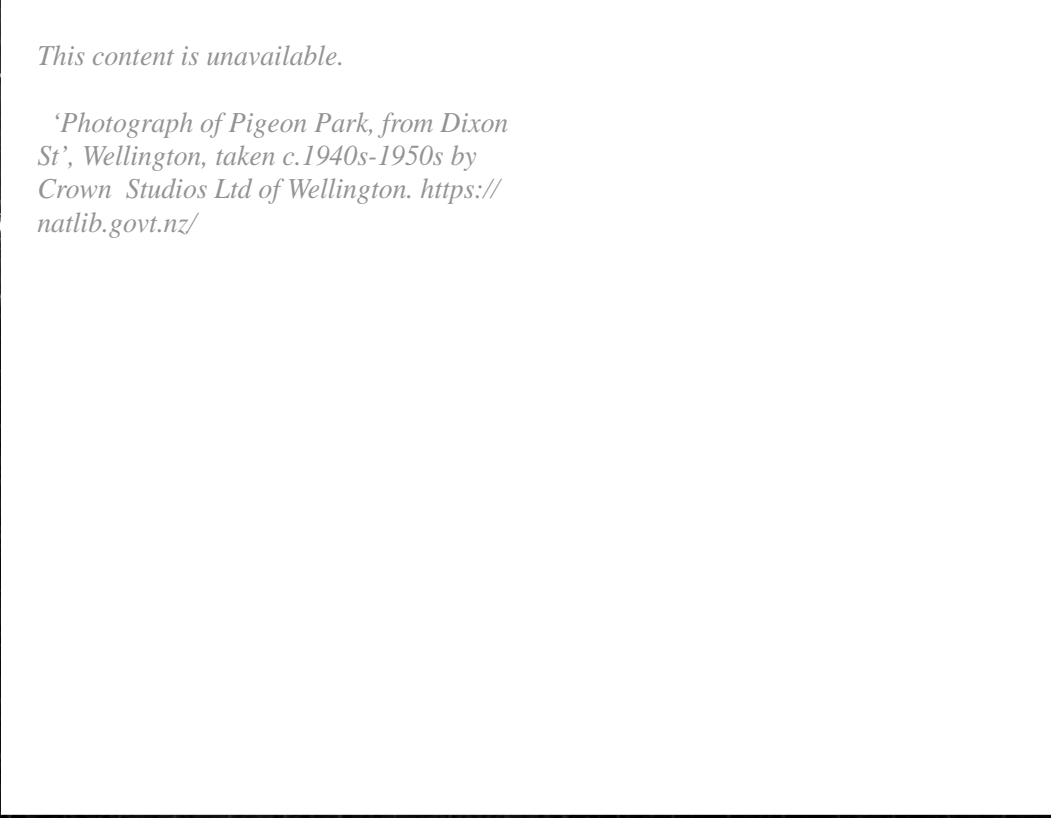

lenzies, “"Progress vs. Preservation; A
Jistory of Te Aro, Wellington", p. 02 .

颔: 35 㖿

Following the relocation of most of the pā, Te Aro became a colonial settlement that quickly blossomed into the center of commerce in Wellington. In 1855 , an earthquake followed by a tsunami raised the land, drained the swamp and destroyed a large portion of the remaining pā, resulting in the loss of essential food sources and other natural resources utilised by the Māori (Menzies, 4). The Waimapihi Stream became buried beneath the site, where it was later contained and diverted through a network of culverts. In 1870, the remaining people of Ngāti Tupaia (of Ngāti Ruanui kin) were forcibly evicted from the site, the pā was dismantled, and the land was subdivided and sold (Menzies, 4)

As the city expanded, numerous streets and urban buildings were constructed directly over the origina pā site. Due to the quickly evolving nature of the urban fabric, the colonial-era buildings- - which represent the colonial heritage of Wellingtonwere also demolished and lost. By 1881, only a few Māori remained at the original pā site.

Opposite Left Figure 3.19. Overlooking Te St through the center. Looking East, down Courtenay Place from the tip of what was formerly known as Pigeon Park, 1928. Opposite Below Right | Figure 3.21. Wist. Studios Ltd of Wellington.
The triangle of land now known as Te Aro Park became the Market Reserve, housing both the police and fire station. In 1891 the land was converted again, becoming Pigeon Park, a popular gathering space for pacifist objectors of World War II and a starting point for protest marches to the Parliament (Cornish, np.). The site remained as Pigeon Park until the late 1980s, when the Wellington City Council decided to honour the intangible Māori heritage beneath the site. 


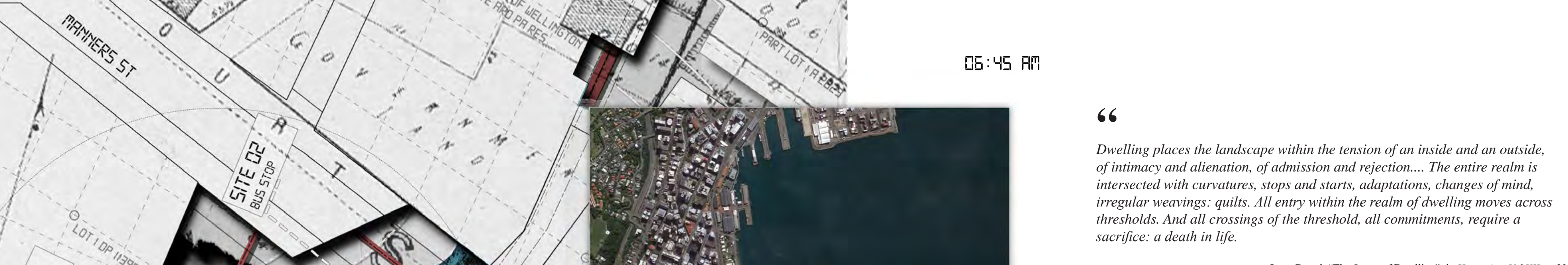

Dwelling places the landscape within the tension of an inside and an outside, intersected with curvatures, stops and starts, adaptations, changes of mind, sacrifice: a death in life.

Jager Bernd, “The Space of Dwelling", in Humanitas Vol.XII, p. 327.
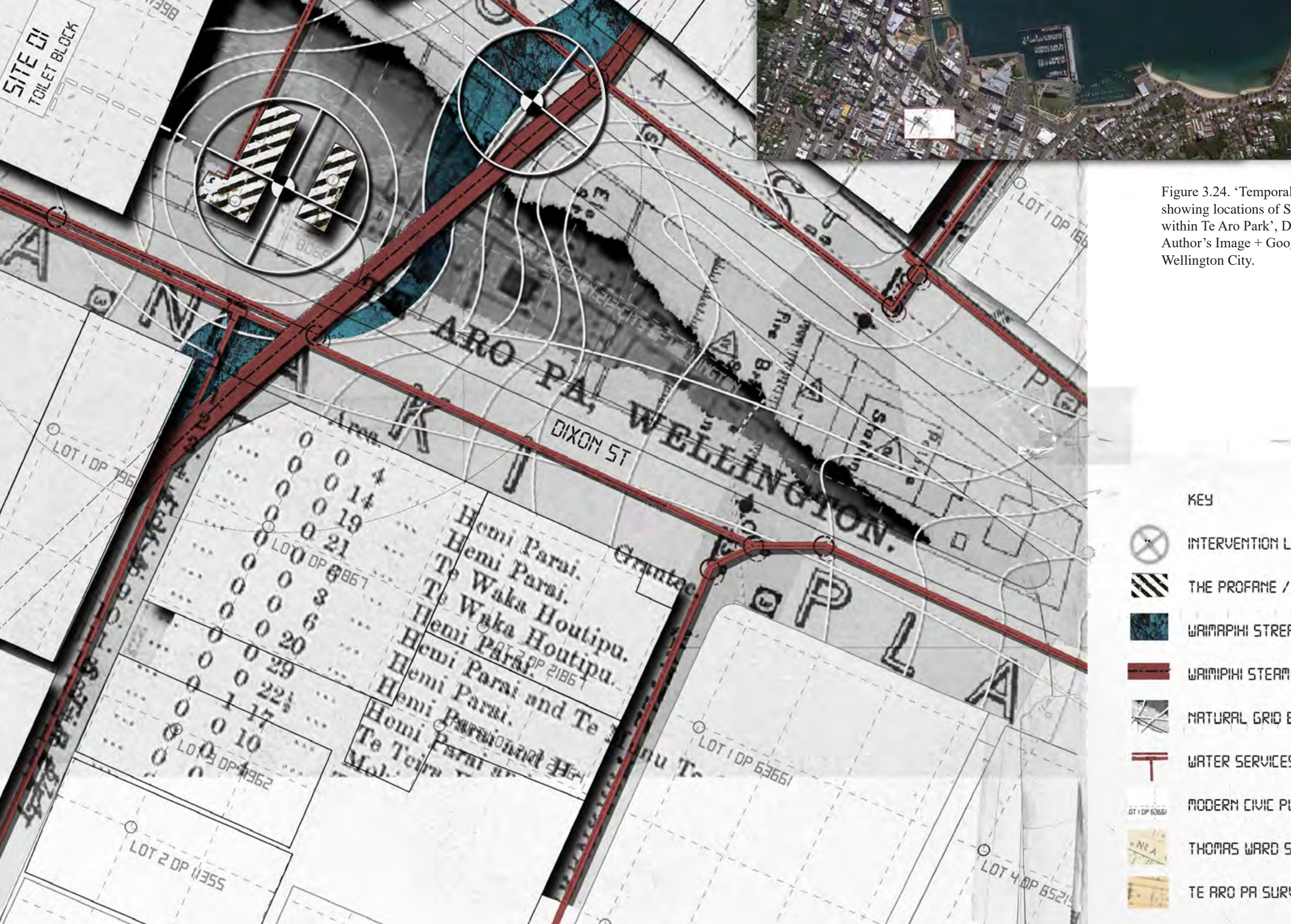

Figure 3.24. “Temporal Site Plan,
showing locations of Site 01 \& 02 within Te Aro Park', Digital Drawing.
Author's Image + Google Map footage

This site plan depicts the locations of both Design Stages 02 and 03, which together represen Preliminary Design. The drawing highlights the temporal layers of Te Aro Park as well as two majo confrontations observed within the site.

The first confrontation, the sacred and profane, is derived from the placement of a toilet block atop derived from the placement of a toilet block atop the original pã site. In Cognition: Design Stage 02, a Preliminary Design solution for this toilet block is designed-primarily in relation to Fetcher's symbolic action 'battle. The designed outcomes for representations addess Ro2, with the formation of a dialectic relationship between site and project - manifested through the confrontatio of the sacred and profane.

KEY

(8) intervention lochtiont

NN the PROFRME / TOLEt

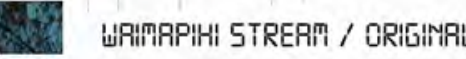

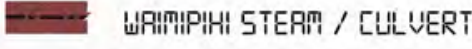

T. MATURRL GRIO BEMERTH

T WRTER SERUILES

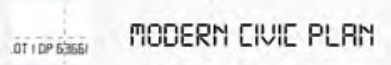

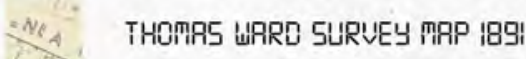

E. TE TRO PR SURUEY MAR IBTI
The second major contextual confrontation exist between the built and the natural, illustrated by relationships between the original Waimapih Stream and its culverted redirection. Activation Design Stage 03, involves the Preliminary Design of a bus stop intervention, this time, focused in relation to Fletcher's second symbolic action, 'progress'. This stage of design primarily engages $\mathrm{R} 03$, attempting to communicate the temporal nature of place identity through speculative progress and journey. 
Täne next undertook the task of increasing light in the world. He obtained light in gradual increments... Light children of Tangotango were aquired in a sequence, fist a single star, ihen phosphorescent light, next all ine stars, the moon. and finally, the sun.

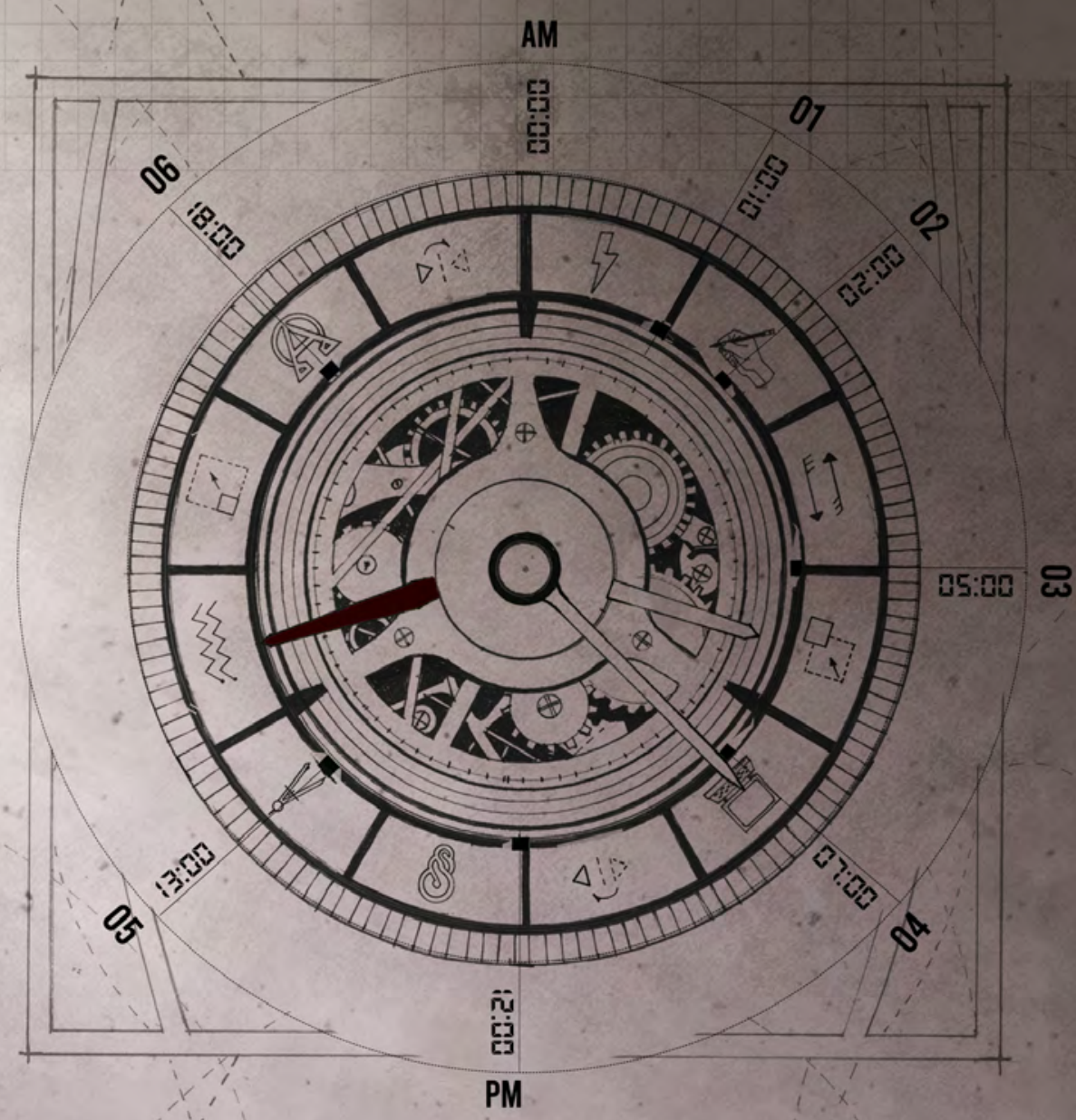

NGĀ MIHI O TE, RA | GREETING OF THE DAY PRELIMINARY DESIGN STAGE 
For every act of construction there is an allied act of destruction. One action cannot take place withou the other. This the only true symmetry in the world, and it is a fearful one..

... Our gain is tied to loss. This principle is so fundamental, yet architects and engineers, as two types of makers among others, forget this. When will they see?

\section{CHAPTER 04}

Ra $\mid$ Greeting of the "Ngà à" Mihio te Preliminary Design Stage of the investigation. It is divided into two sections, which are aligned Pre aligned

4.1. Cognition | Design Stage 02 uses the redesign of the public toilets in Te Aro Park, design of the public toilets in Te Aro Park,
Wellington as a vehicle for addressing Confrontation in relation to RO2. 4.2. Activation | Design Stage 03 uses the reWellington as a vehicle for addressing Progess Wellington as a vehicle for addressing Progres
or Journey in relation to RO3. 


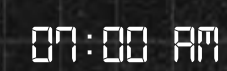

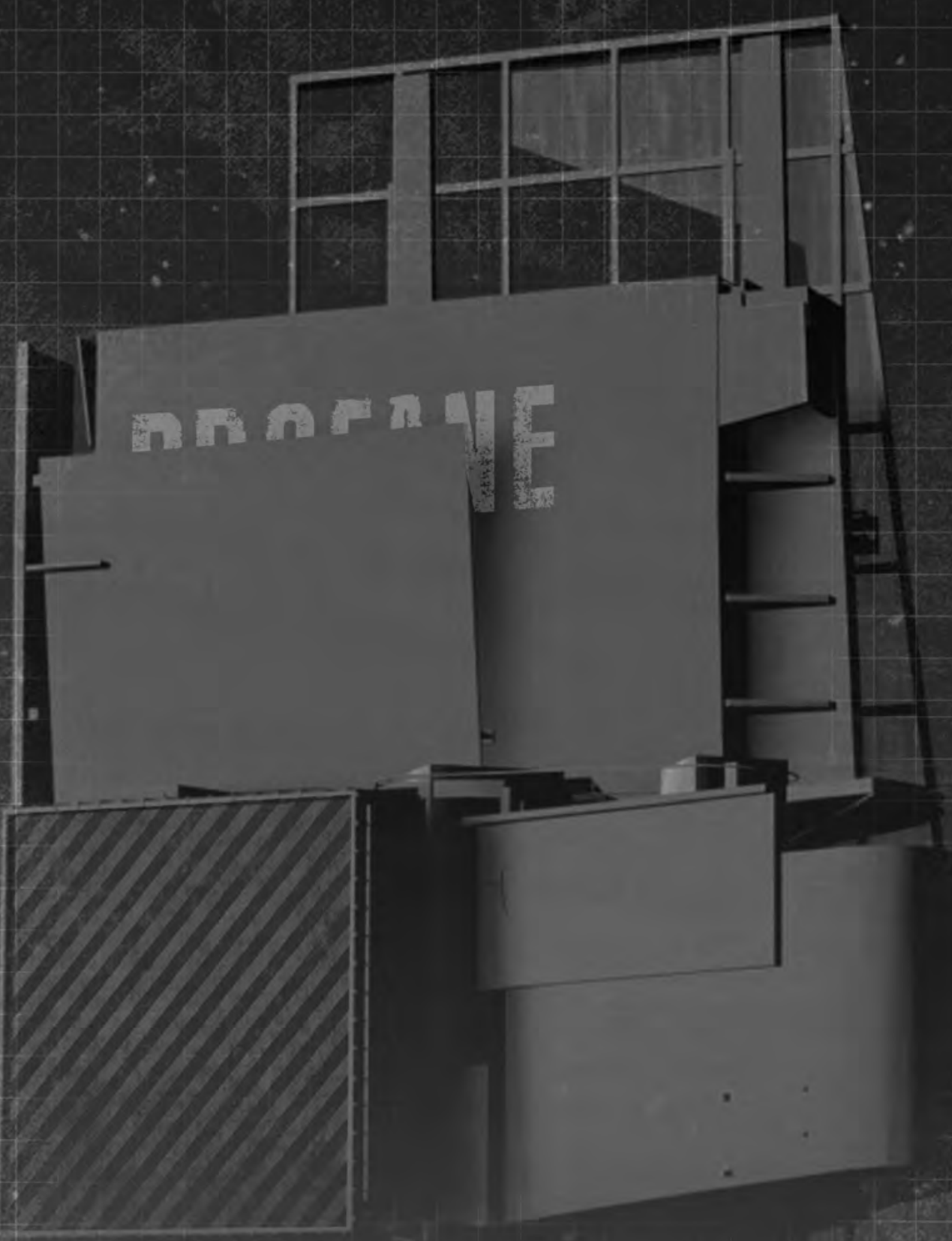

(0). 5.

DESIGN STAGE 02

THE UNVEILING: AN ARCHITECTURAL BATTLE

Section 4.1, Cognition | Design Stage 02, represent the first half of the Preliminary Design Stage. It divided into the following four sub-sections:

- The Research Site: Te Aro Park Toilet Block - Drawing Battle (Confrontation

- The Unveiling

- Critical Reflection

This section uses the re-design of the public toilets in Te Aro Park Wellington as a vehicle for addressing allegorical architectural design as Battle or Confrontation in relation to $\mathrm{RO} 2$ :

To explore how the representation of allegorica architecture as battle or confrontation can arch establish contextual dialogues (spatial help establsh contexual dhalogues (spatial heritage stories relating to a site. 


\subsubsection{DRAWING BATTLE}

(CONFRONTATION)

Lines of Confrontation" defines article "Drawing line or the pase "frines a link between suggests the nature of war, similarly to architectural planning, lies in the claiming of physical, cultural. social, religious and economic borders, with the outcome being "a series of demarcation lines the denote territorial claims" (Hamel, 203).

In representing the space of war, lines of confrontation delineate a burdened space reduced to the thinness of a graphic line. The

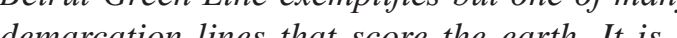
line that separated the city of Beirut for sixteen Jears during the war in Lepan (1975-1991).

- Catherine Hamel, “Drawing Lines of Confrontation" p. 201

Hamel's correlation between the 'frontline of a war' as a 'line of confrontation' provides an approach towards representing and engaging the symbolic where the delineation of sides becomes the fund thes bestes his undertanding of a frontine can offer citical insights into intepretation where one must go beyond the obvious demarcation line in order to understand the complexities resulting from the line self. Hamel suggests that the line of confrontation is not a single concept; instead, it is simultaneously political, dynamic and contested, becoming eithe site of resistance or a symbol of defeat (Hamel,

The extreme conditions of the frontlines of The extreme con war point at the limituions of architectural betwentwo sides reveals a much more complex tug of wor with many supporting roles confrontion referred to is notong of aggressive confromition. It is the collision betwe oggressive exposition. It is the collision between modes of expression and experimsc... The reverberation

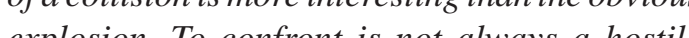
explosion. To cor entris is not always a hostile act. To confront is also is act of comparison,

Catherine Hamel, “Drawing Lines of Confrontation”, p. 203

Hamel's description of the 'line of confrontation' dopted and interpreted in the thesis research, where the dialectic 'battle' between site and architecture is similarly, not one of agression, but ratecture f mediation. It is an attempt by both op entities to establish a 'truth' through a reasoned entities to establish a 'truth' through a reasoned an
considerate dialectic confrontation. 



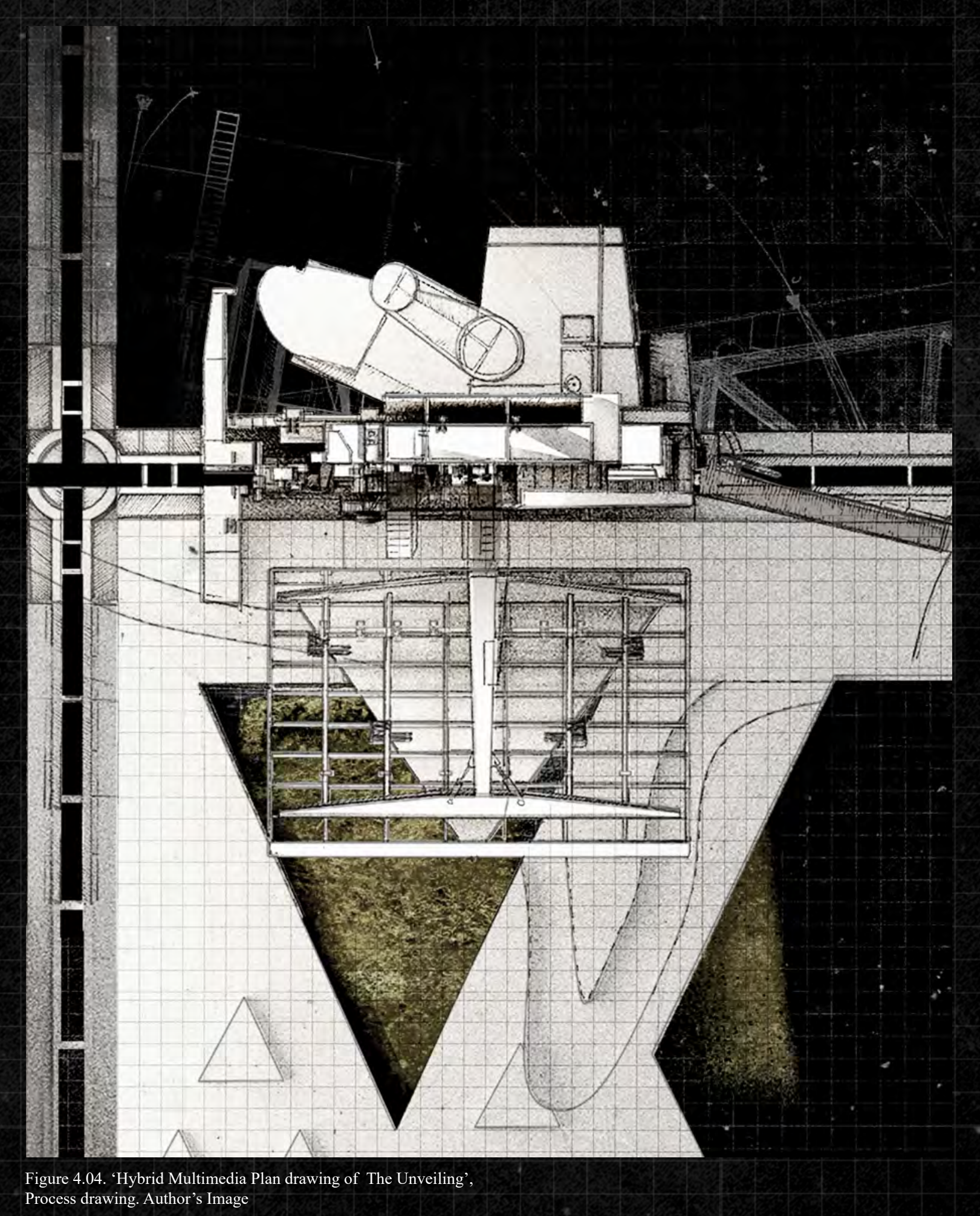

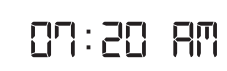

The sacred identity of the pā is interpreted as with a secret door opening into a small, concealed Pullman's dæmon 'soul' that simultaneously sleeping compartment, designed to protect users in embodies Hogue's 'site.' The profane identity of the case of assault or to be used by the homeles the toilet block 'site' becomes the 'mask'/ 'project' as emergency housing. On the opposite side of the that initially concealed it. Both dæmon and mask mirror is an excavating mechanism, which has cut are placed in a 'battle' through the application away and removed a section of the landscape's of the architectural 'mirror'. Reminiscent of 'mask'. In doing so it has revealed the layering Pullman's silver guillotine and the Surrealist of heritage beneath. The mirror now wears this painting provocations, this mirror exists upon a mask itself, both as an acknowledgment of the site drawn timeline (fig 4.04), a reference to Hamel's beneath it, whilst simultaneously protecting its 'line of confrontation' The mirror itself reflects the dialectic relationship between oppositions. It is neither sacred nor profane, but rather the narrato to tell both sides of the contextual narrative of speculative architectural drawings, where from alternating perspectives, with its dynamic each drawing functions as a development on the architectural language - adopted from Design Stage previous. These drawings attempt to highlight the 01-allowing one to interpret the movements that allegorical confrontation of sacred and profane allegorical confrontation of sacred and profane as well as the physical architecture that manifest ead to the current intervention.

is confined to the realm of the drawing where the On one side of this mirror, a toilet is held-suspended off the ground-reflecting a desire to preserve the sacred integrity 


\section{ㅁำ: 25 俩}

Following the initial kitbash, 'The Unveiling' was manipulated with a focus on mirroring allegorica

narrative through the detailing of this Preliminary

Design. Fig. 4.05 is a digital speculative drawing

depicting these iterative detail developments in

order of their temporal position. The following full-

page spread depicts the final Iteration D (far righ

fig. 4.05) through both fig. 4.06 in elevations and

fig. 4.06a in plan, where a key describes how both

allegorical devices and architectural programme

become intertwined within the designed outcome.

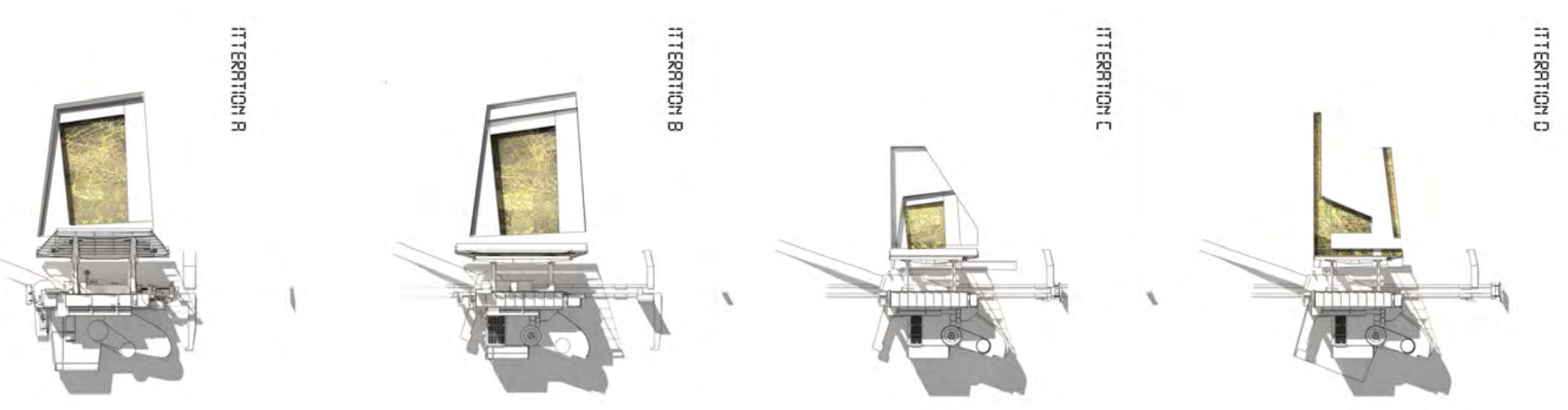

Figure 4.05. 'Iterations A, B, C, D: a temporal progress',

Digital Process Drawing. Author's Image

Overleaf | Figure 4.06 ‘ The Unveiling in Elevation'
Speculative Digital Drawing. Author's Image

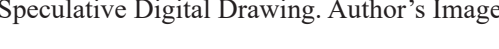

Overleaf | Figure 4.06a. ‘The Unveiling in Plan,
annotated', Speculative Digital Drawing. Author's Image
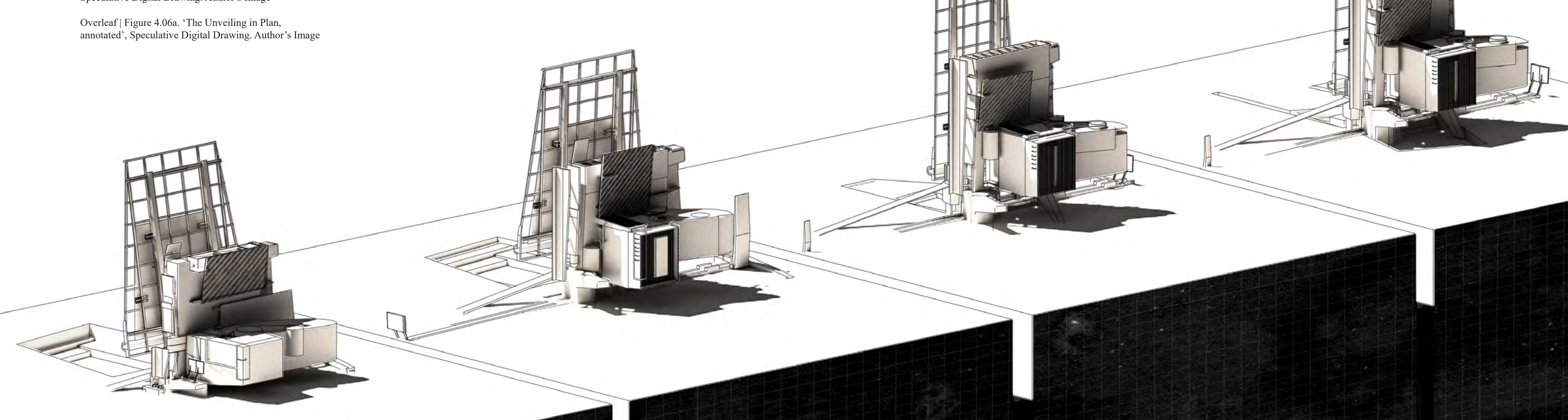
목: 琩 $\mathrm{Am}$

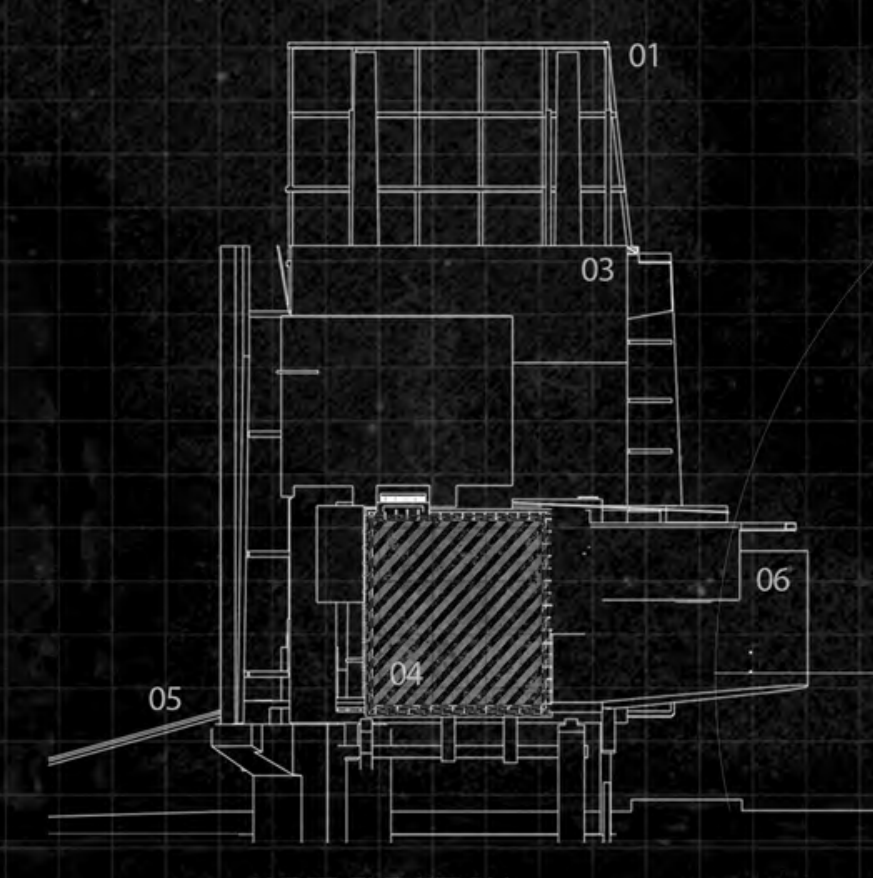

WEST ELEVATION

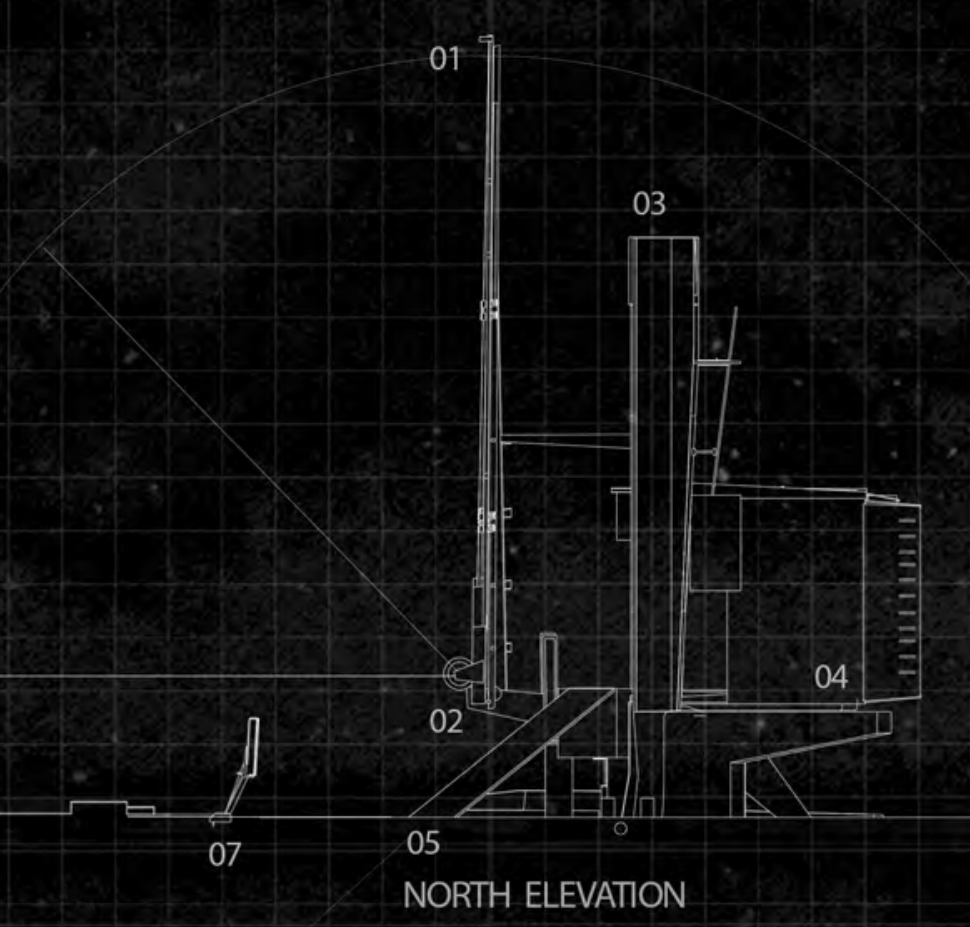

a
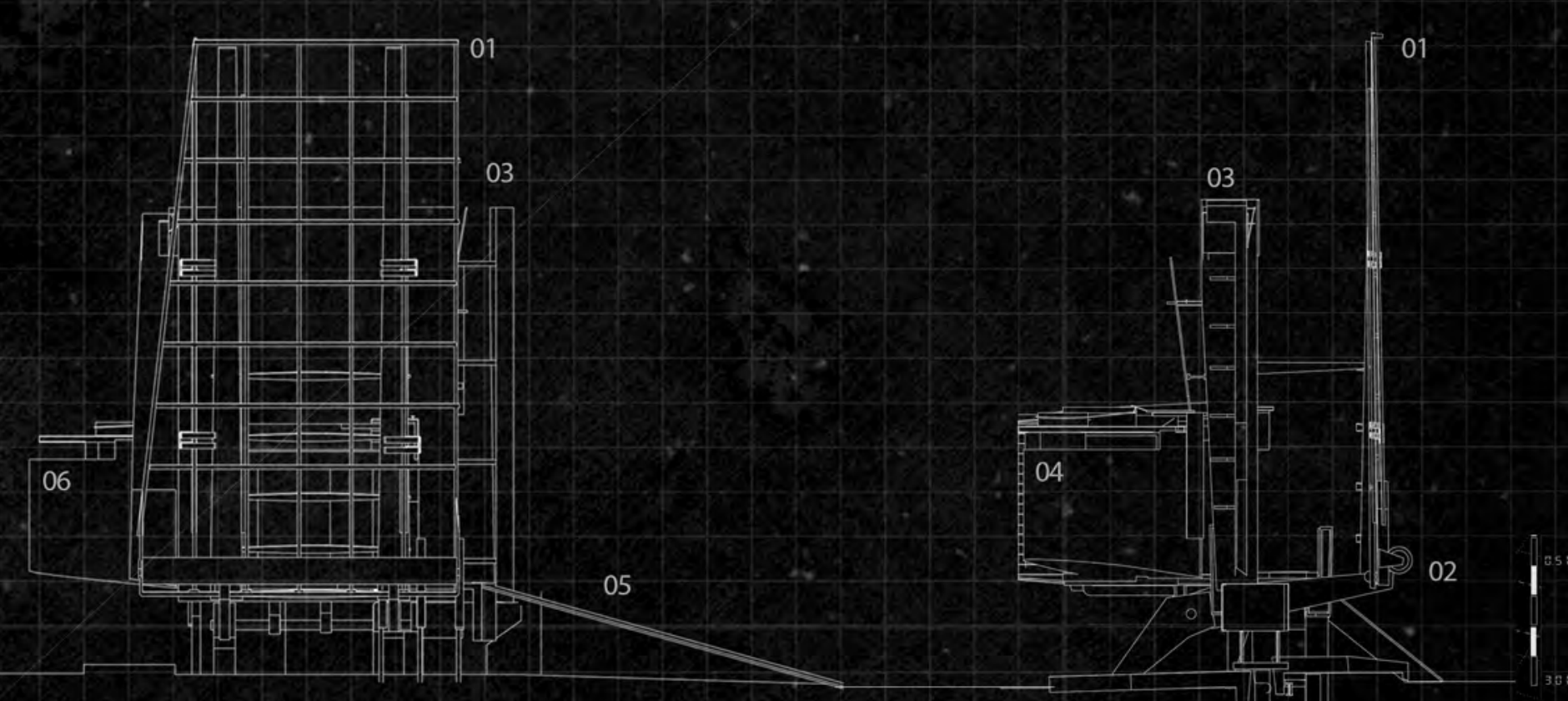

EAST ELEVATION

SOUTH ELEVATION

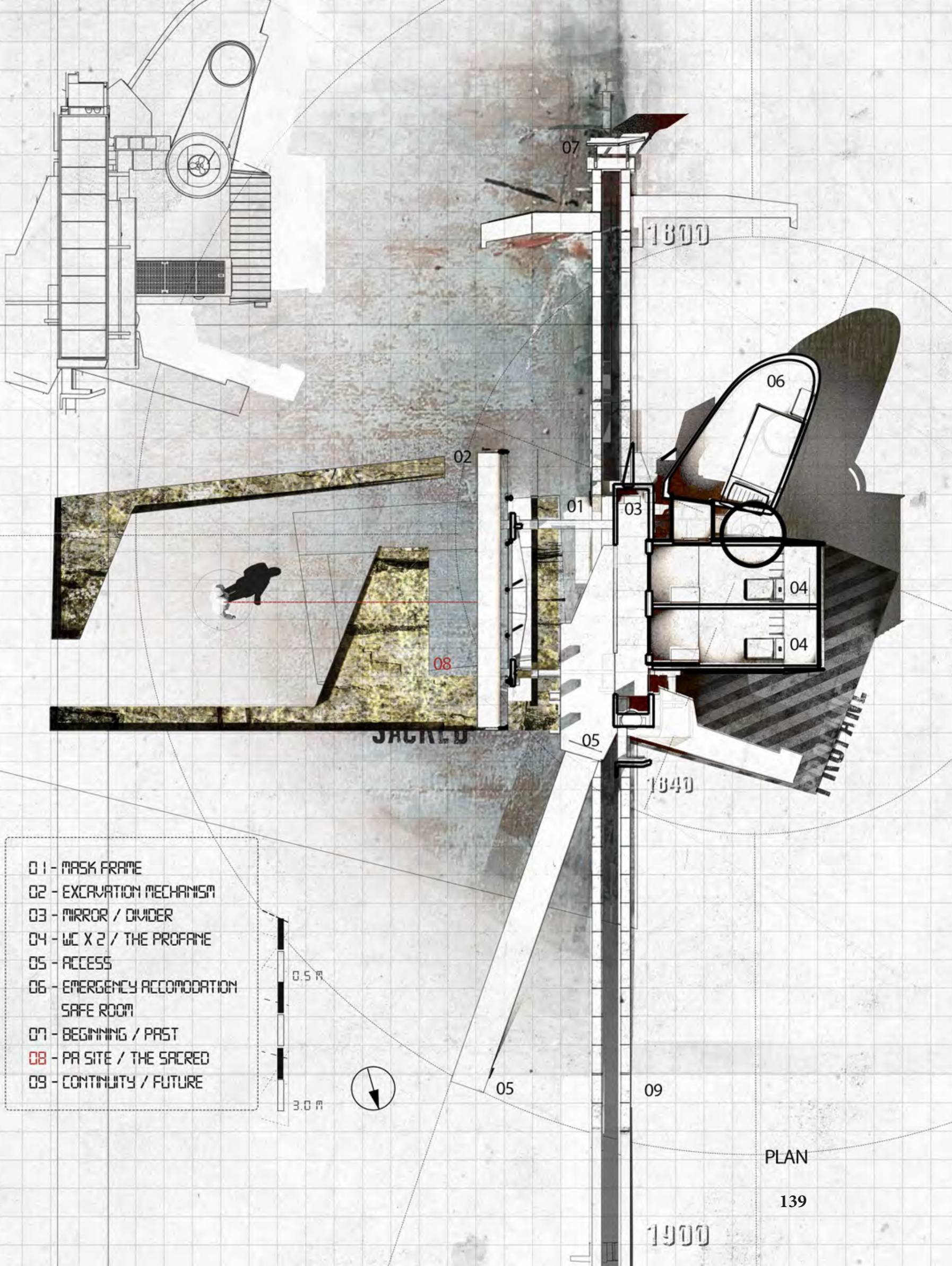




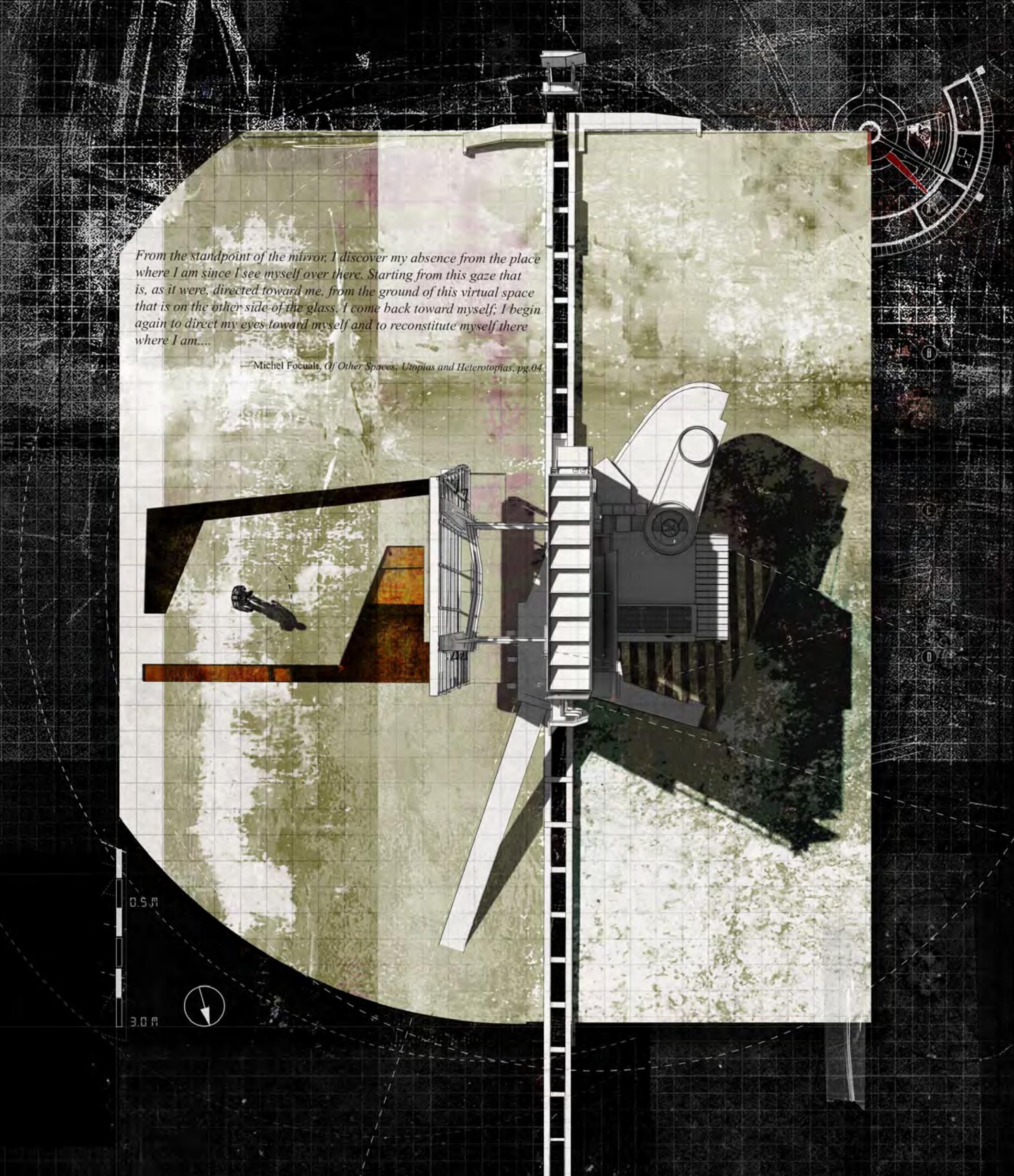

민:湫

Opposite | Figure 4.07. ‘A balanced
Confrontation', Speculatative Architectural Roof Plan
Auther's Image

Author's Image

Overleaf| Figure 4.08 \& $4.08 \mathrm{a}$.
'Experiencing Allegory. Enter

'Experiencing Allegory, Enter
This Speculative Roof Plan (fig. 4.07) attempts to depict the entirety of the evolving confrontation through a collision between allegorical an architectural representation techniques. This method involves a conventional representation of architectural elements, combined with a textural representation, highlighting allegorical intentions. These textures depict 'The Unveiling' site upon a gritty texture representing an urban mask. The mask is hovering above a void, adapted from Inception, Design Stage 01-a reference to the realm of Te Pō from which it came. Through a cut in the mask of the land - as a result of the narrator - we are able to see the sacred identity shown in 'gold' beneth the shadow of the narrator, another shallower cut is seen textured in hazard lines, exposing the profan identity of the toilet above it.

In the following pages, figures 4.08 to $4.08 \mathrm{~b}$ attempt to place the viewer inside the realm of the speculative drawing from fig.4.07, depicting a series of experiential perspectives of the design. In this realm the architectural render retains its allegorica power through the application of textures, symbols and text. 


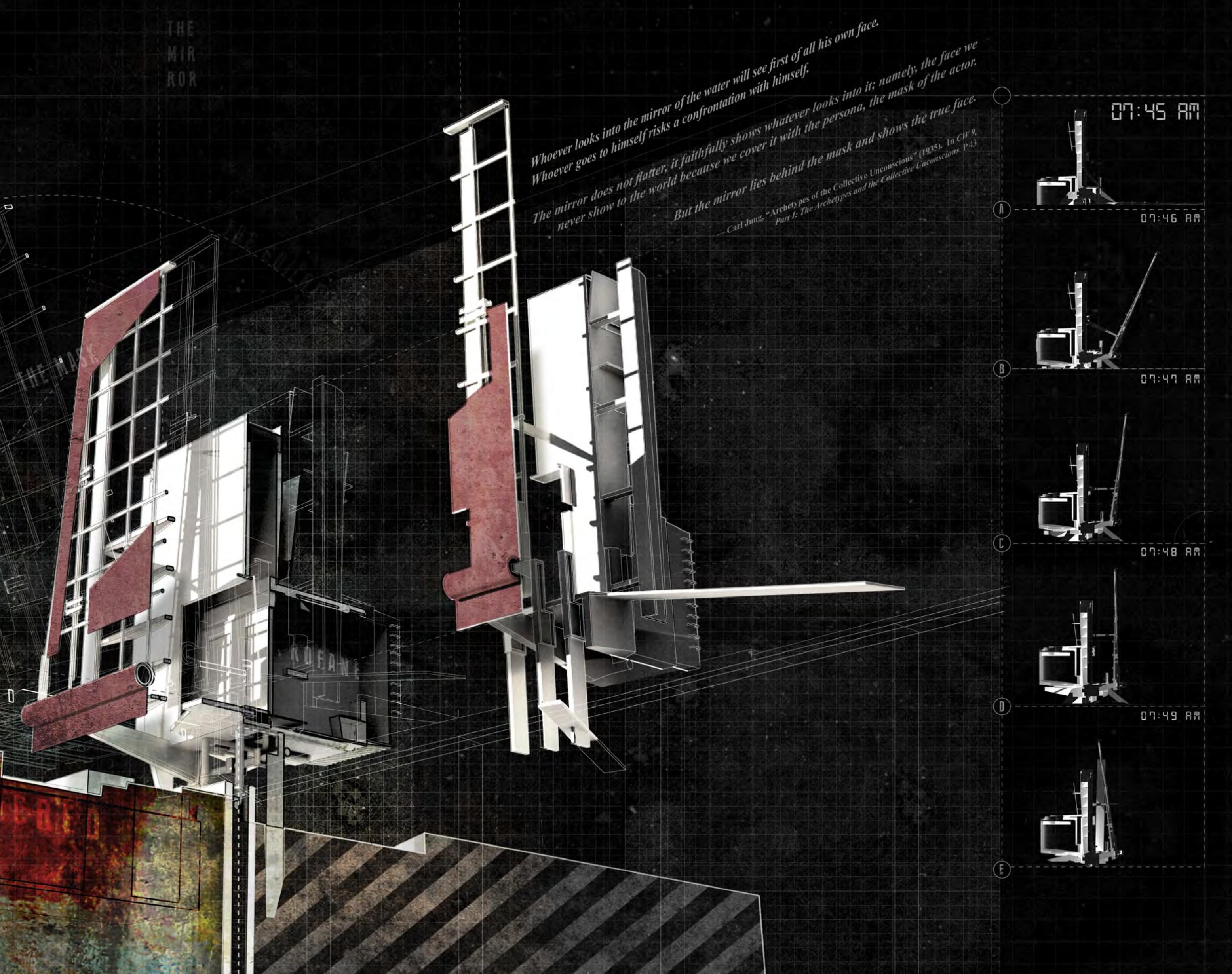




\subsubsection{COGNITION:}

CRITICAL REFLECTION the toilet block, 'The Unveiling, explores an identity between 'ste drived from a primarily aims to address Research Objective 02 .

To explore how the representation of allegorical architecture as battle or help establish contextual dialogues (spatial relationships) that help unveil the essential heritage stories relating to a site.

The speculative architectural drawings that depict The Unveiling attempt to go beyond tradition representations of architectural confrontationpushing beyond the line of demarcation-to highlight the allegorical 'battle' This is achieved through an abstraction of textures 'site' and viewing angles, as well as an introduction of tempona

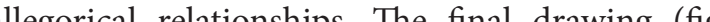
409) depicts the 'The Unveiling' with a tempora dance annotated entirely through a singular static me The explodion as invites the viewer to look past the mask through a miror and into the profane identy whin a singular static inage. This method of drawing proves successful for communicating a layering of allegorical and architectural information, which will be taken forward and developed in Design Stage 03 , the second section of this chapter.

Although the Design Stage 02 outcome focuses on $\mathrm{R} 02$, it is also explicitly relevant to R01, where the provocational foundation of Te Pō is developed and applied in direct relation to the research problem. Through its representation the design also begin touching on $\mathrm{R} 03$, where the drawings that depict 'The Unveiling' begin to engawe a sense of the 'Temporal in the form of 'virtul time' (the montaged the 'vette). It is in this context hat Research Objectives 01-03 begin to overap; as provection pelationships, all become fundmental elements the developing allegorical architectural project.

In Section 2 of this chapter, Activation | Design Stage 03 , the focus is directed to $\mathrm{R} 03$, where the heritage of the Waimapihi Stream is used

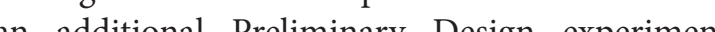
exploring a more tempory resresention of the 'battle' by inviting allegorical 'progress' to becone 'further intertwined within the investigation through in introdetion with the dawing pocess. duction within the drawing process. 
4.2 AC TIVATION: DESIGN STAGE 03

\section{THE LOST STREAM:}

AN ARCHITECTURAL PROGRESS

Section 4.2, Activation | Design Stage 03 , represents the second half of the Preliminary Design investigation. It is divided into the following four subsections.

- The Research Site: Te Aro Park Bus Stops - Drawing Progress (Journey)

- Foundation

- Critical Reflection

This section uses the re-design of the public bus stons in Te Aro Park, Wellington as a vehicle for addressing Progress or Journey in relation to $\mathrm{RO}$.

To explore how the representation of allegorical architecure as progress or journey can help establish temporal qualities (time-hased relationships) that help unveil the essentiol heritage stories relating to a site. 
its oul?

antity-pull man's tomenon

titions, an sppostenity for dialectics a seperotion - pullmars doemon

into a cohesice frame wo kh

nporal frame work

- cause and effect

from Pullman's provocations ell a stoy through darlectics.

Disider of
Liongues - Guilotine - thresholds - Soul as pa-mask Sould pa- mask - Toul is weteled - mircor som is

- Doumon cage istiraline - Frame - Soul is flow - Dance and other acuences.
呾: 2 听 $\mathrm{Am}$

In this world, time is a visible dimension.

(hit as one may look off in the distance and see houses, trees, mountain peaks that are landmarks in space, so one may look out , stretching off dimly into the far future.

And just as one may choose wether to stay in one place or run to another, so one may choose his motion along the axis of time.

Some people fear travelling far from a comfortable moment. They remain close to one temporal location arely crawling past a familiar occasion. Others gallop recklessly into the future, without preparation for the rapid sequence of passing events.

-Alan Lightman, Einstein's Dreams, p. 133-134.

THE LOST STREAM

The Proposition Statement for the
thesis articulated how the investigation is framed around Philip Pullman's fictional trilogy His Dark Materials, in which Pullman explores the provocative notion that the inner self or the 'soul (dæmon) of a character can exist separately from the outer 'corporeal' self - a means of revealing a of that character Pullman's literary provocation is used in Design Stage 03 to investigate how it might be applied to awaken the 'soul' of a work of mishecture, by actict form place identity.

Fig. 4.13, depicts the sketchbook where the idea for the bus stop was incepted. It depicts the metaphorical flow of the stream diagonally dividing the gridded page - manipulating elements of the architecture through the strength of its current. This sketch experiment led to the initial digital design

Figure 4.13. 'Scan from The Sketch Boor experiments on the following pages. where The Lost Stream was Incec
Hand Drawing. Author' Image

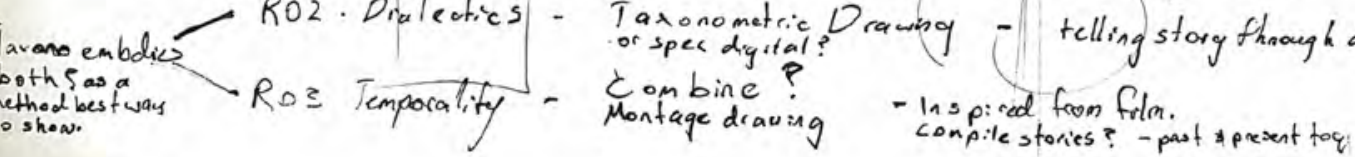




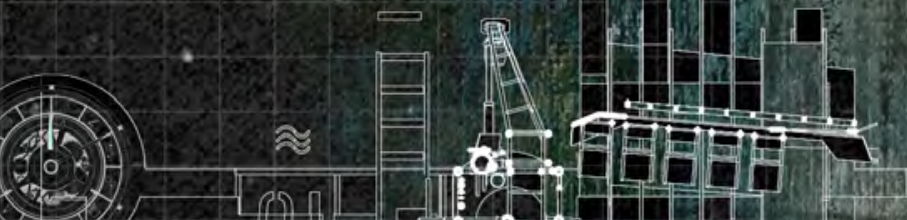

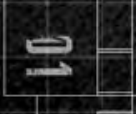
ino: y

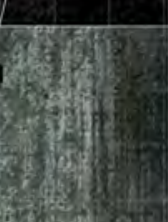

क $+$

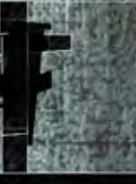

Leff| Figure 4.14. 'The Lost Stream, Author's Image.

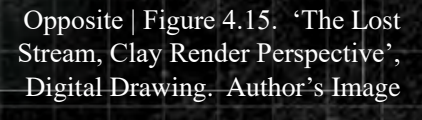

吗: 跑

The design for the Bus Stop is initially derived

Because the programme for the bus stop requires a stop on either side of the street, the design is able to Waimapini Stream, to relate to Fletcher's allegorical engage the theoretical framework of the 'Mirror. concept of 'progress or 'journey'. By bringing The two reflect one another, but with important together an essential story from the past to coexist differences. At the same time, the dual interventions with a story from the present, the design constructs establish a 'Threshold' through which the bus must a temporal allegorical confrontation between the pass. In the figure below, we also witness the 'Mask' 'built' bus stop and the 'natural' stream.

(left) that the bus stop wears, as well as its inner soul' (right), both facing one another.

In the allegorical narrative of the bus stop of the stream are revealed flowing beneath the architectural intervention invites the visitor to concrete. These gouges are centralised by the become a daemonic agent within the allegorical bus stop, which uses them to supply water to the sequence, where the identity of the stream is surrounding vegetation of the park-allowing the continuously acknowledged through the re-filling Waimapihi Stream to metaphorically, once again, of the surrounding gouges-ensuring that the sustain its surrounding environment. stream remains active and alive.

In the following figures, these notions are explored further through speculative drawing methods, where the drawing process invites discrepancies

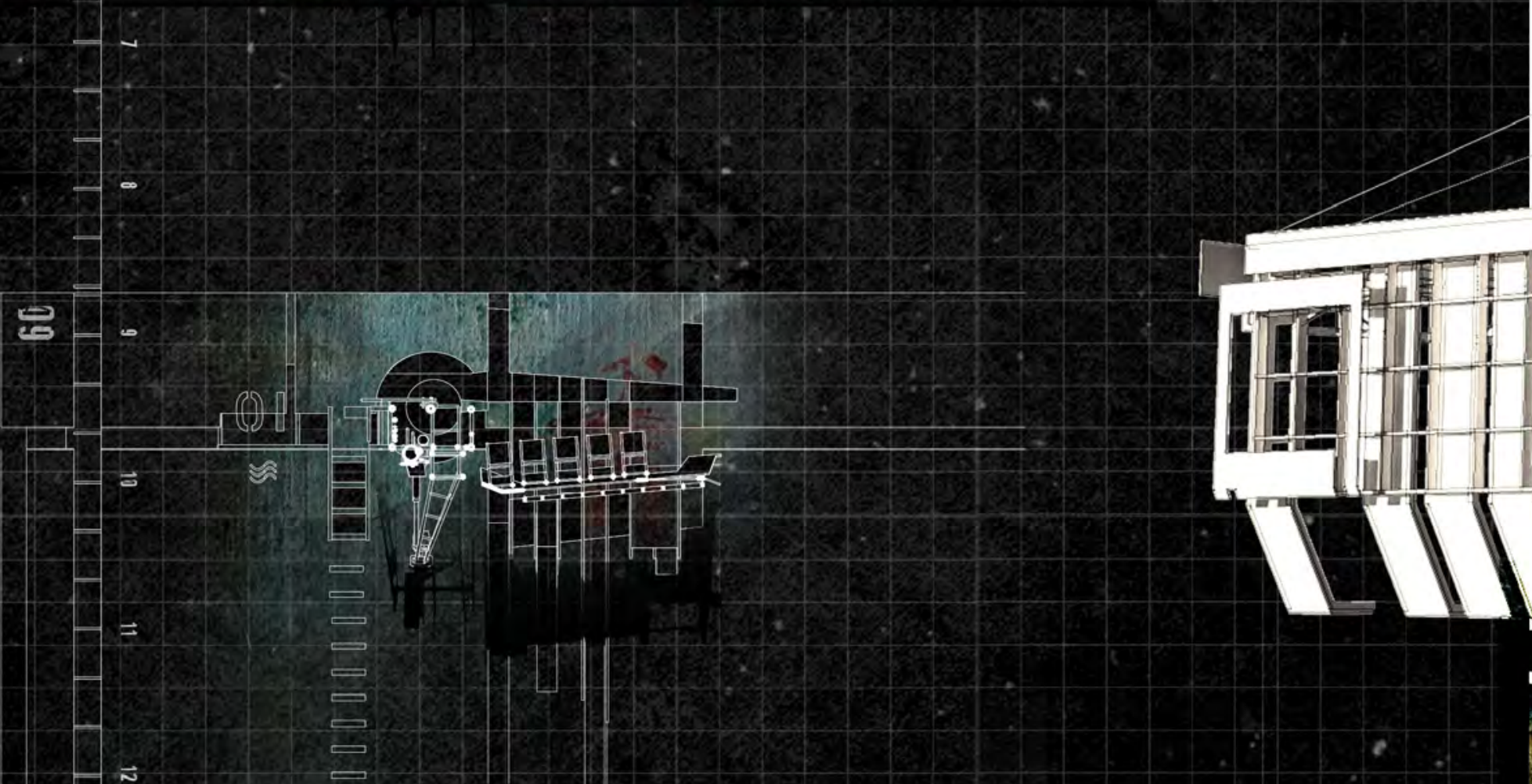
and unexpected deviations to manipulate the allegorical 'progress'. This is informed by further devices including shifts of axis and variations to the mirrored element that further reflect the marks of their making.
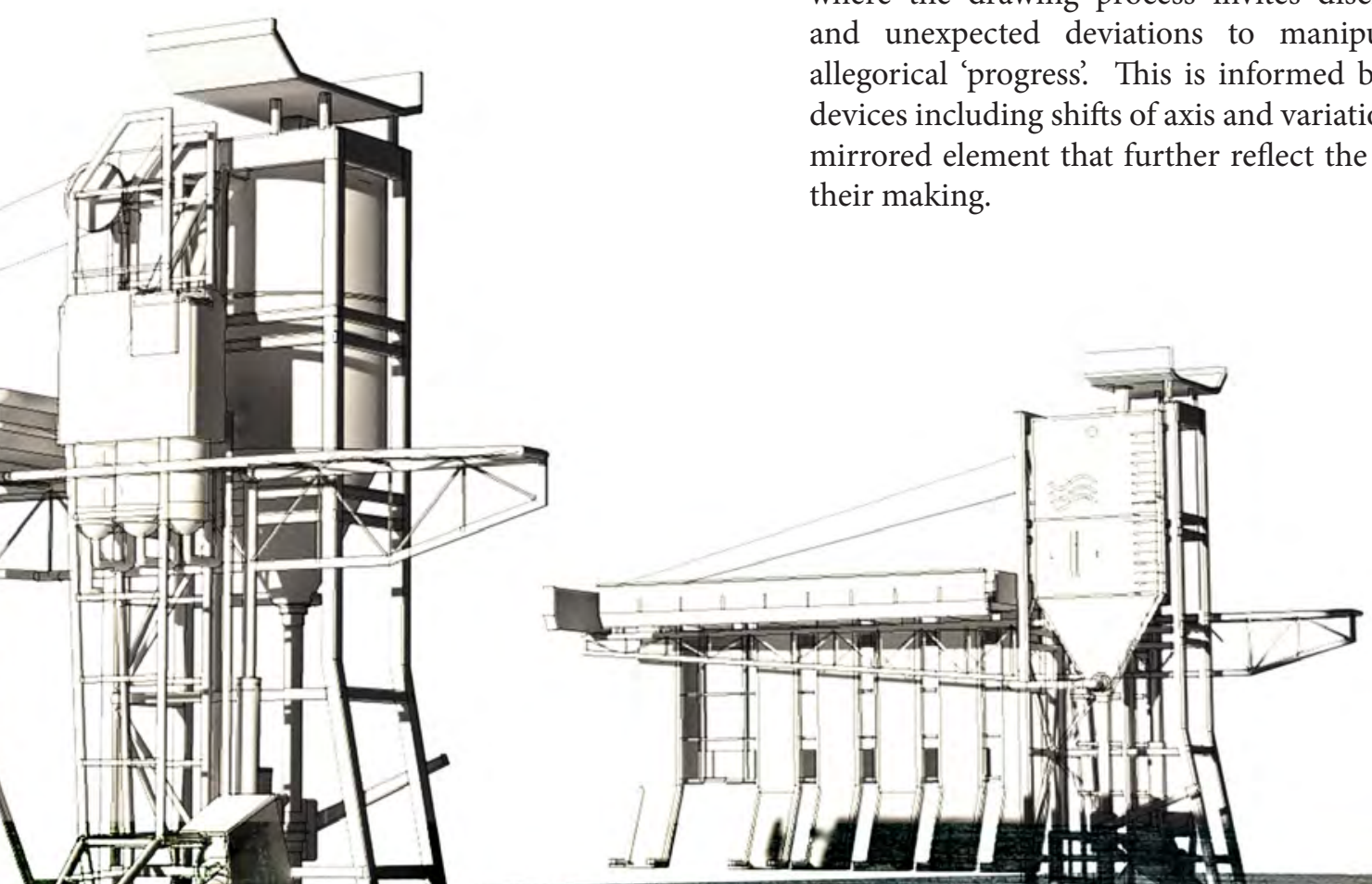


\subsubsection{DRAWING PROGRESS}

(JOURNEY)

Design Stage 03 uses the re- Annotation, the physical residue, referring to the design of the public bus stops in
Te Aro of recording new corporeal data based on the
collision and overlap of the denotation and the Progress or Journey in relation to $\mathrm{RO}$ : Allegory as Progress (Journey)

To explore how the representation of allegorical architecture as progress or journey can help establish temporal qualities (time-based relationships) that help unveil the essential heritage stories relating to a site.

In order to introduce temporal qualities into the speculative drawing outcomes, Design Stage 03 draws from the speculative drawing theory of Bryan Cantley. In his article Towards a Toxonometric Architecture: D-con: an, Bryan Cantey intodric If one could annote a drawing (or more to the point if a drawing had the capacity to annote itself), would the indications suggest a world or an there be such an animal as an annotative architecture?

Architecture: D-con: an, Bryan Cantley introduces of annotation, which in its own nature begins to annotate itself. Cantley describes this Taxonometric Drawing System as a system of instuction and Donstruction, that denotes, connotes and antates imultaneous - a drawing that functions as both he author and the reader (Cantey, 2018, 53). The Taxonometric Drawing is conp. major traits: 01, Denotation, the description of the bject, refering to the designation or rendeing of an architectural object; 02, Connotation, the imaginative association, referring to the 'readings' connotation (Cantley, 2018, 49).

In fig. 4.16 Cantley's drawing Surface Topology Experiment, follows this taxonometric approach. The Denotation appears through the architectural subject matter; the Connotation appears through ymbols, textures and other fragmented element ssociated with its meaning; and the Annotation ppears through the wireframe interconnecting that annotate the drawing as a dynamic and hifting entity.

Cantley's application of the Taxonometric Drawing is explored and adapted within Design Stage 03, where it is used as a developmental tool to push the design of the bus stop further through its epresentation within an allegorical 'progress. The final drawing outcome for Design Stage 03 looks to depict the entirety of 'The Lost Stream' within a single drawing - both in terms of the confrontation of site and project, and the dialectic sequence that it evolved from it. The Taxonometric Drawing in his context functions as a design expering itself, as it invites abstraction, deconstruction and allegery to play a fundamental role in the design

ssociated with its interpretation(s); and 03 


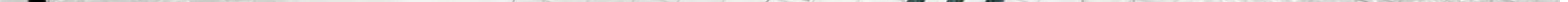
explores how a moliminary design experiment Waimapihi Stream might be achieved. Building on the initial concept, the allegorical 'progress' of the bus stop is evolved into three stages - break, split and drift-relating to a representation of cause and effect.

The 'break' allegorically alludes to the initial collision, where the river collides with the origin position of the bus stop, twisting and breaking it from the grid axis and dislodging it from its initio position.

The 'split' then represents the formation of Manners Street, which allegorically causes the 'whole' to become divided in two. The process of this split (reminiscent of Pullman's Silver Gullotine) leate gouges in the uban fabric, with discrepancies betwen the dual bus stops (mirror) referring to the nature of this severance.

The 'drift' then as a final transition is reflected in the further movement and deconstruction of the lower right entity (fig. 4.17) as a result of the Waimapih Stream's current. Ultimately, this redesign attempts to more clearly engage the identity of the Waimapih Stream engaging its allegorical force upon the 

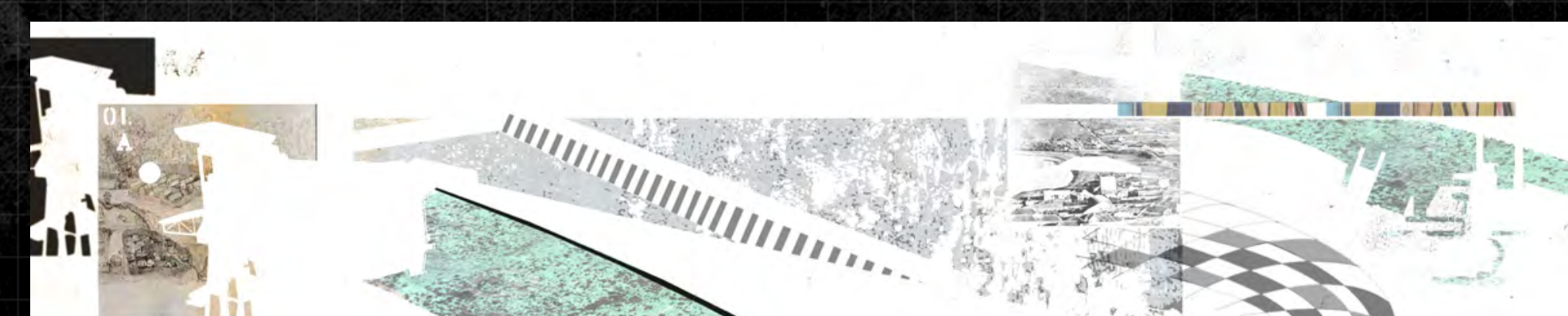

$x_{104}$
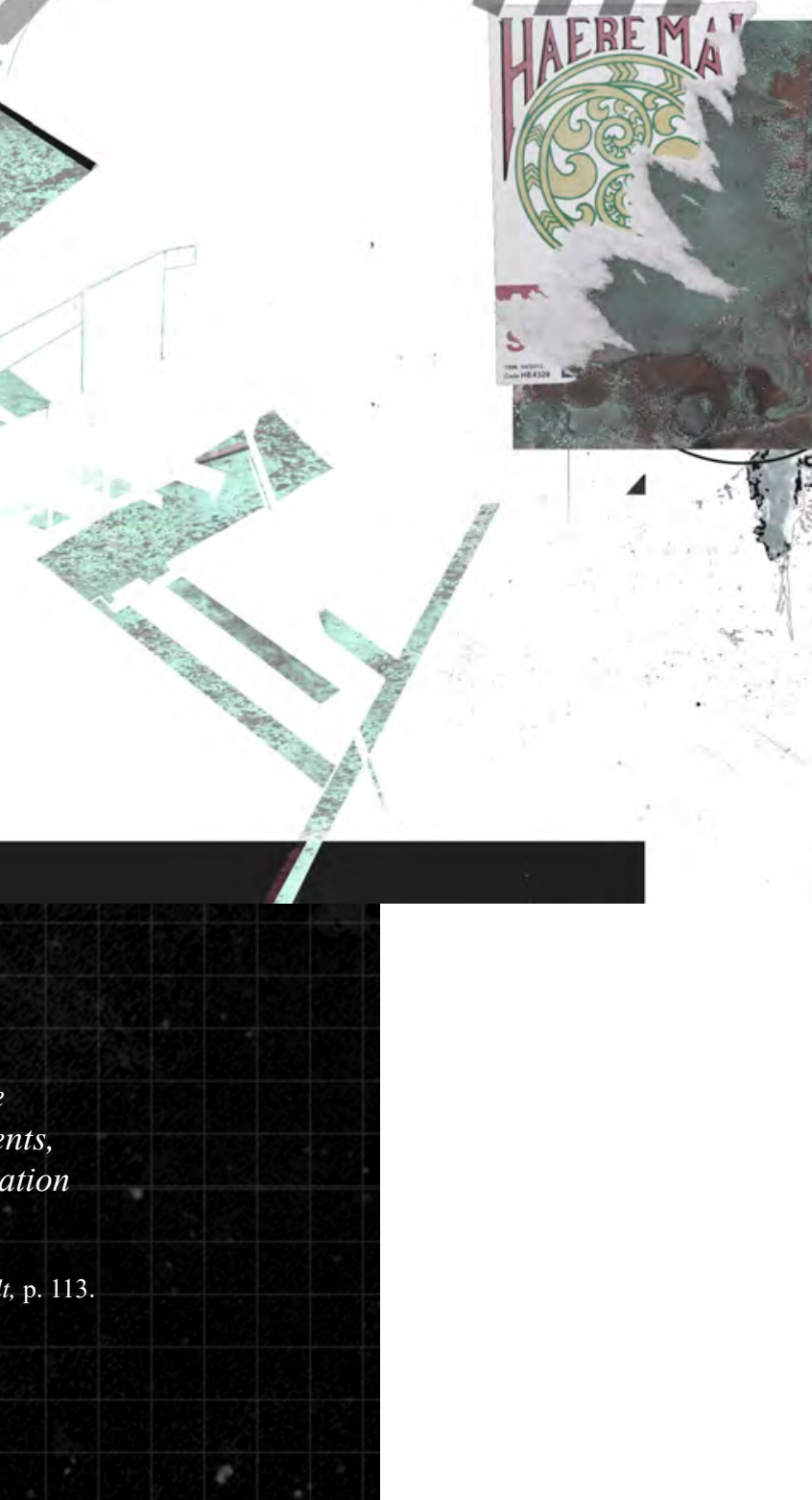
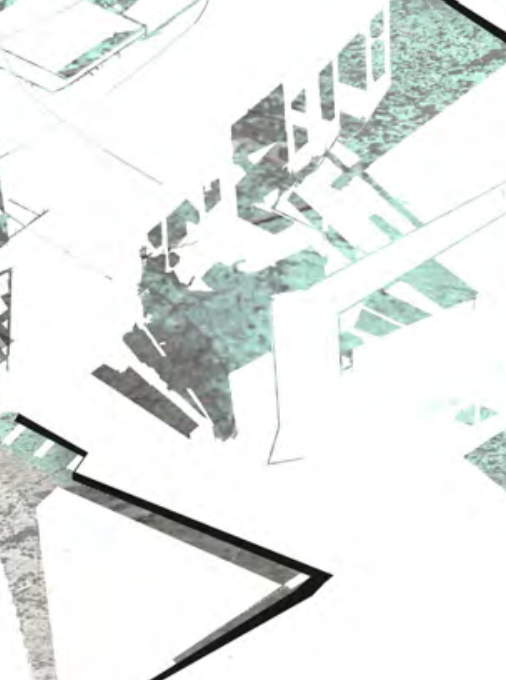

S6

lil

This transformation becomes the history of site as place, while the cognition of forces and vectors becomes the memory of events, the cagr ary sediments of place and time, definition and confirents, of an everchanging reality.
CONNOTATION The figure to the left represents the second of the three layers that will be integrated in the formation of the Design Stage 03 Taxonometric Drawing. This second layer, the Connotation, functions as the depiction the developing allegorical battle and progress. This layer marks the effect of the allegory attempting to describe relationships of confrontation and temporality through the treatment of textures and colour. The textures themselves evolve from the developing thesis pallet, with the red/gold first appearing as a manifestation of the sacred, where the lost stream is inherently connected to the lost $p$ site. The green/blue inherently becomes a further development of the sacred, resembling the natura in the form of the lost stream. Through the centre a grey fluid grid alludes to the void - originating from Design Stage 01- xisting beeth the pating revealed only by the actions of the silver guillotine. Rust and other eroded textures represent the temporal 'progress' of this allegory appearing the beginning of the timeline and benth page, which combined with historical photograt symbolise a transition in time through the eroded layers of the page. Finally, on the right of the ene layers of he a 2 current site. 


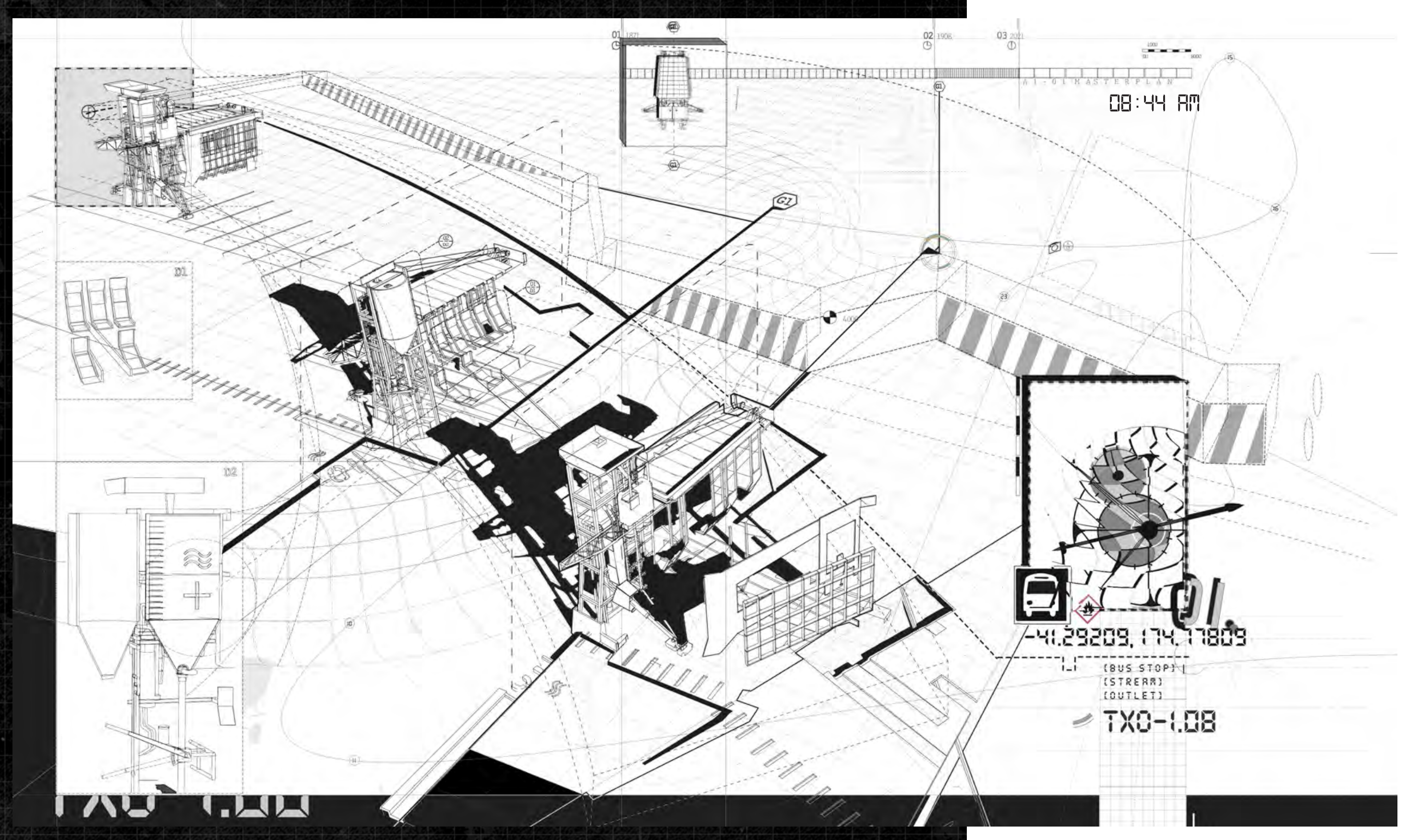

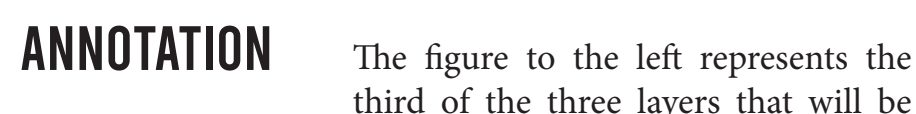
integrated in the formation of the Design Stage 03 Taxonometric Drawing. The final layer of the drawing, Annotation, functions as the residue, occurring as a result of the collision between the Denotation and the Connotation. It functions as an act of dialectic mediation, recording new corporea data, based on the various confrontations between physical and allegorical ideas. The Annotation functions simultaneously as a system for reading the drawing highlighting shifts and breaks dynamic movement focal points, and the timeline sequence of the battle.

The drawing provides hints and clues relating the holistic allegory appering in the form of fragmented symbols and detail elements-interconnected through a wireframe weaving of subject matter. These symbols refe to both provocations and context including G1 for the Guillotine Cut key dates associated with the heritage transformations; and the numbered equence of the allegorical dance. Developments to the two-dimensional key diagram (raised square in fig. 4.20 ) enhance the possibility of interpretations where the key diagram combines the alethiometer with symbols relating to place and the bus stop. The Annotation layer becomes, like the bllegorical architecture of 'The Unveiling' a 'narrator' collisions, where the confrontation has evolved

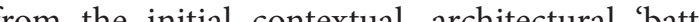
now beconing a fendamental product of the

The drawing is clearly not... a set of building intstructions or a depiction of a particular pace it is an invitation to abandon order. The drawing itself is a fluid, boundaryless, unpredictable environment in which every idea... deliberate or accidental, serious or ridiculous, revoulutionary or merely subversive-is let loose to metastasize.

Ruth Keffer, 'Loudpaper. Volume 4 Issue 3', Mechuduzu, p. 54
Above | Figure 4.20. 'Taxonometric
Annotation, Layer 03', Digital Drawing Author's Image

Overleaf | Figure 4.21. “Taxonometric Drawing of The Lost Stream, Three Layers Combined',

The final outcome of Design Stage 03 is shown in verleaf. It represents the three layers uperimposed. As a taxonometric drawing, its goal $\mathrm{RO} 3$ by establishing the tempor qualities that help unveil the essential heritage ories relating to a site. 


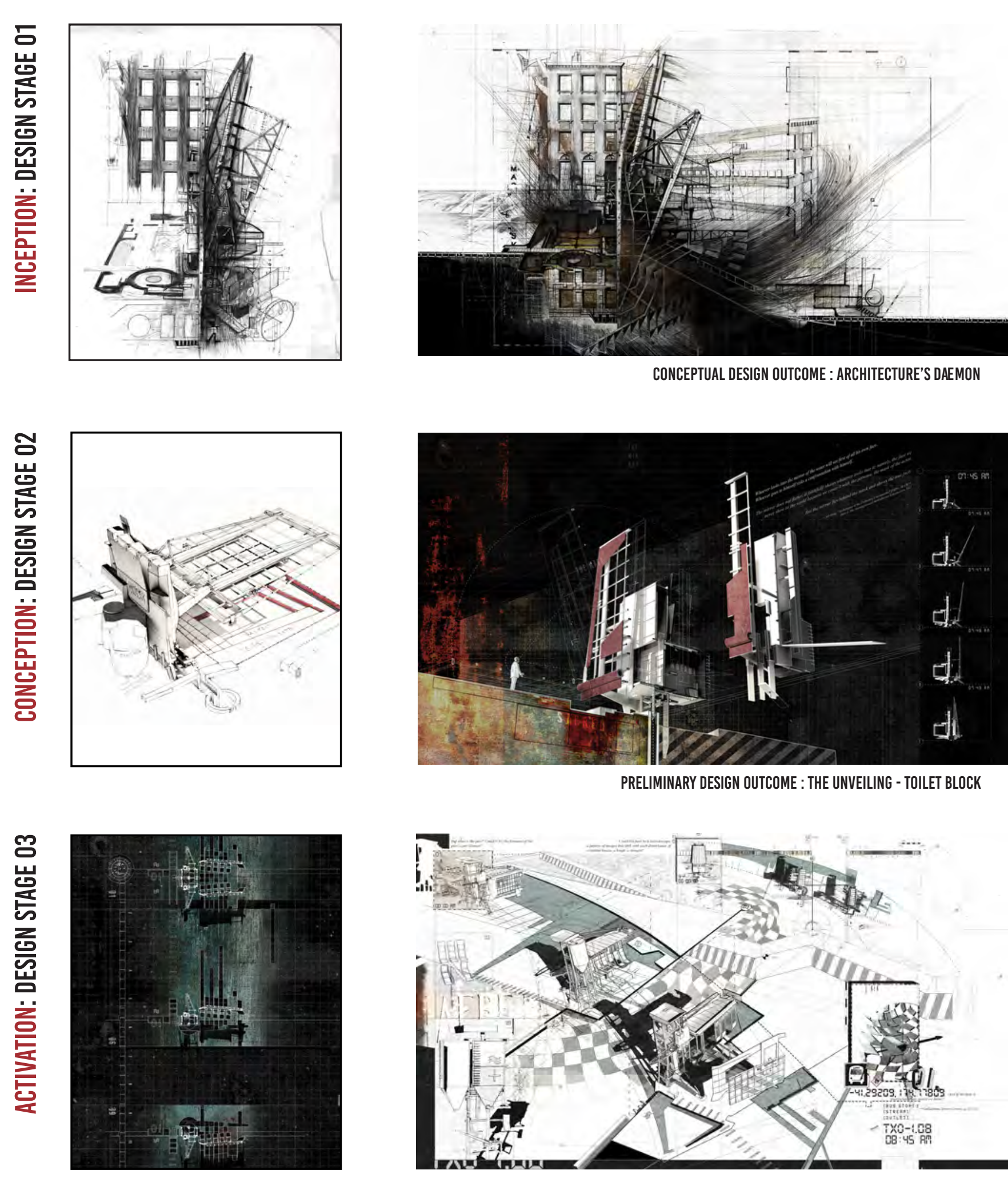

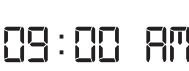

Opposite | Figure 4.23,

Author's Image
CODEX 01:

CRITICAL REFLECTION

This marks the end Aro Pā and my own concealed heritage. Codex 02

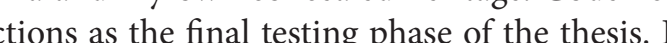
Chaos \& Potential, allegorically symbolised by the becomes an opportunity to refine and repeat the movement from the perpetual night into the light, in methodological approach to Codex 01, in relation Codex 02. At this point, a methodological approach to the design of the Bellagio Ataahua Apartments on for the allegorical architectural project has been Taranaki Street, adjacent to Te Aro Park. This site for established and tested. This methodology is defined the Developed Design experiments is also located by three key stages of design, where the first stage above the remains of Te Aro Pà-a rich contextua Inception utilises the freedom of the hand to Incept opportunity. Codex 02 functions as a standalone the allegorical project. The second stage Cognition allegorical journey transporting the viewer from then transitions the outcomes from Inception into Inception to Activation through Design Stage the digital three-dimensional realm of architecture, 04, Culmination. This journey transitions from with a focus on establishing a dialectic allegorical the hand sketch through digital iterations, to the battle between architecture and the heritage stories Taxonometric and final renders, shifting between that form its place. The final stage Activation then modes of 'battle' and representations of 'progress's focuses on the representation and development of The boundaries between stages become blurred as his allegorical architecture through the tool of the drawing methods and allegorical actions overlap, to represent a temporal dialectic confrontation hrough a singular image.

Ultimately, Codex 02 reflects the desire to more fully engage my own concealed Māori heritage as The three design stages of Inception, Conception well as the need to establish a more specific and and Activation will be redeveloped and then clear identity for place that integrates the learnings taken forward into the Developed Design Stage of from all previous design stages. in the attempt to Codex 02, called Culmination, Design Stage 04. address the Research Question:

In this design stage each methodological stage of Inception, Cognition and Activation is combined and repeated Code 02 intoducs a geater ynthesis with Tikang Mäori provocationseflecting we desire to more fully prgage inherent Tan themes relat both to the context of the Te

How can urban architecture help to reawaken the transformative heritage stories that form as its inh hitants to have a place to stall türangawaewae? 


\section{AM / CODEX 01}

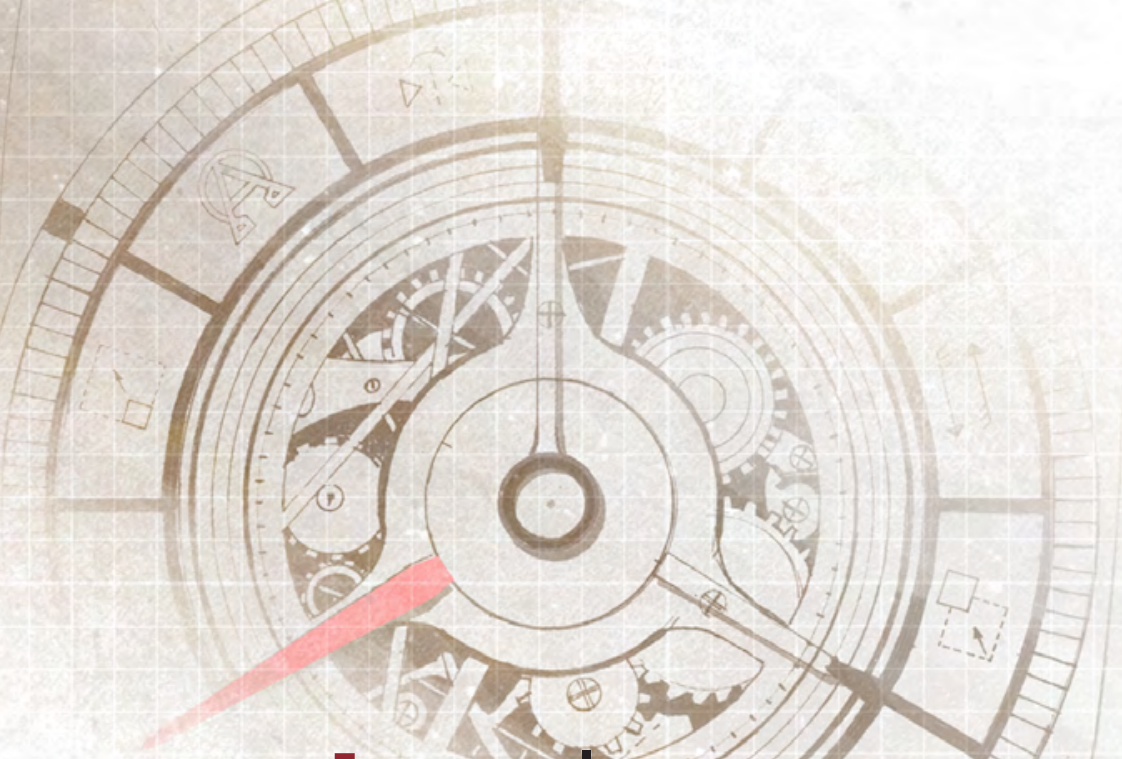

TE AO MĀRAMA | THE WORLD OF LIGHT

This thesis is structured as two bound volumes (codices) that represent a journey along an allegorical timeline, from one volume (codex) to the other. Codex 01, titled Te Kore | Chaos \&

Potential, represents a journey that takes place during the hours of darkness, from midnight to the arrival of the rising sun. It contains all of the design-led research and the design experiments that underpin the final outcomes. Codex 02 , titled

Te Ao Mārama I The World of Light, represents a

journ that takes place during the hours of ligh, journey that takes place during the hours of
from to the hour of the setting sun. 


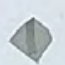

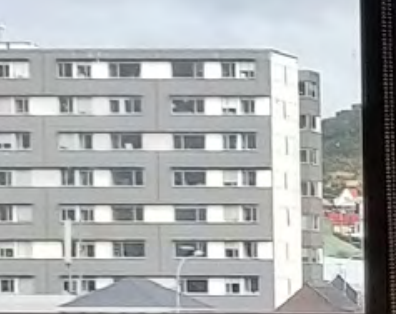

iT iii
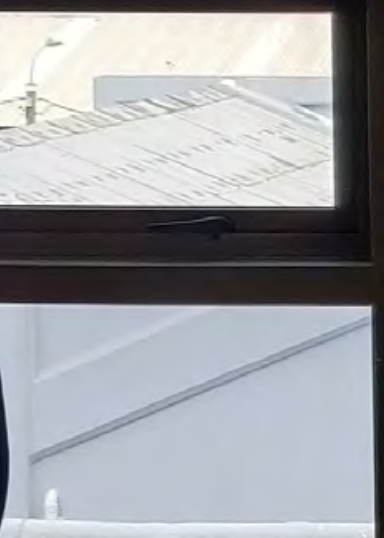

tomisuctionth

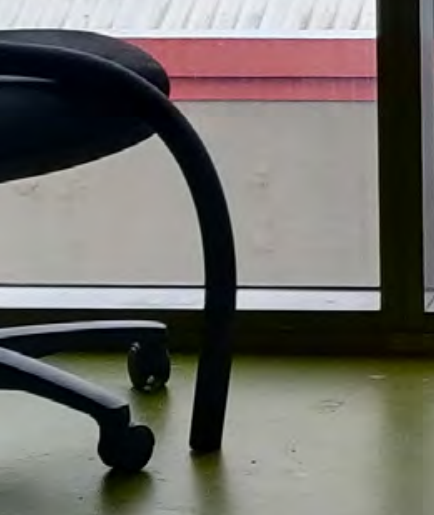

Figure 5.00."Contemplation', (5)
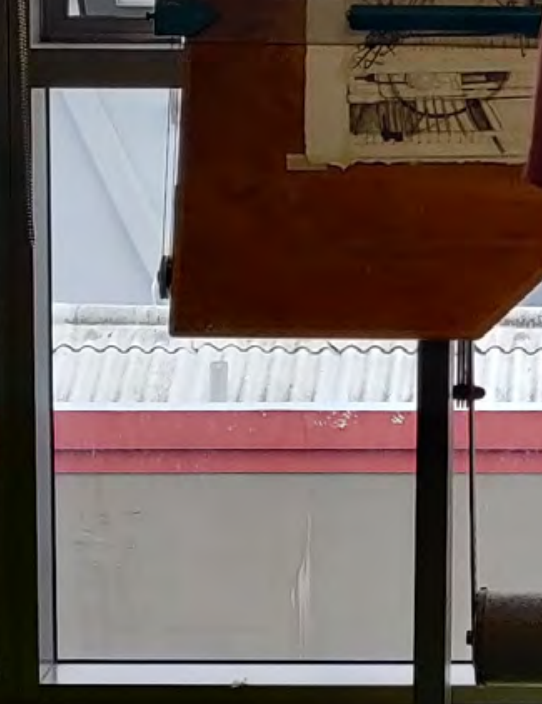

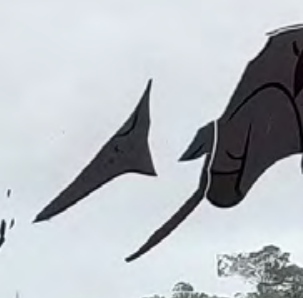

$\rightarrow$ a
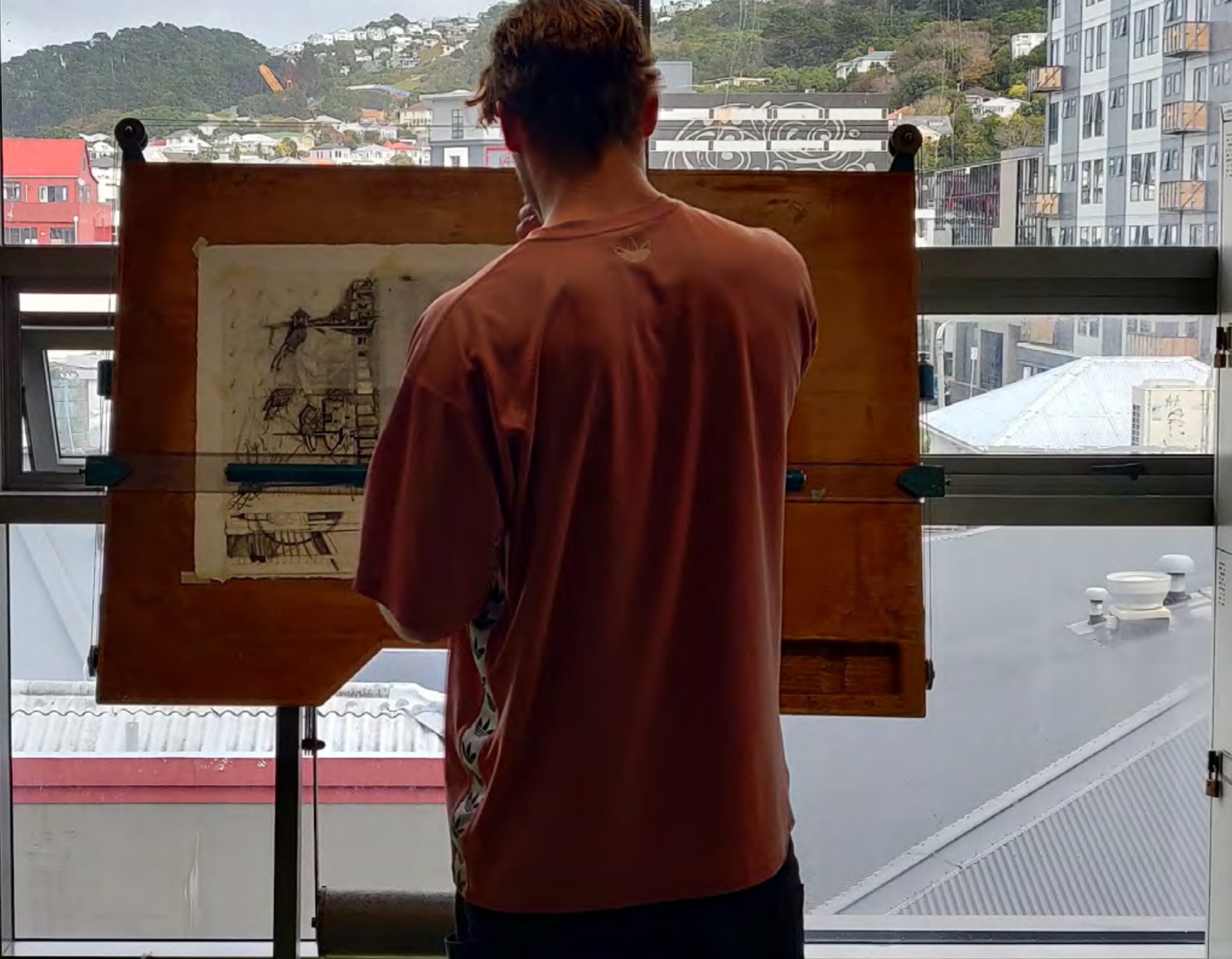

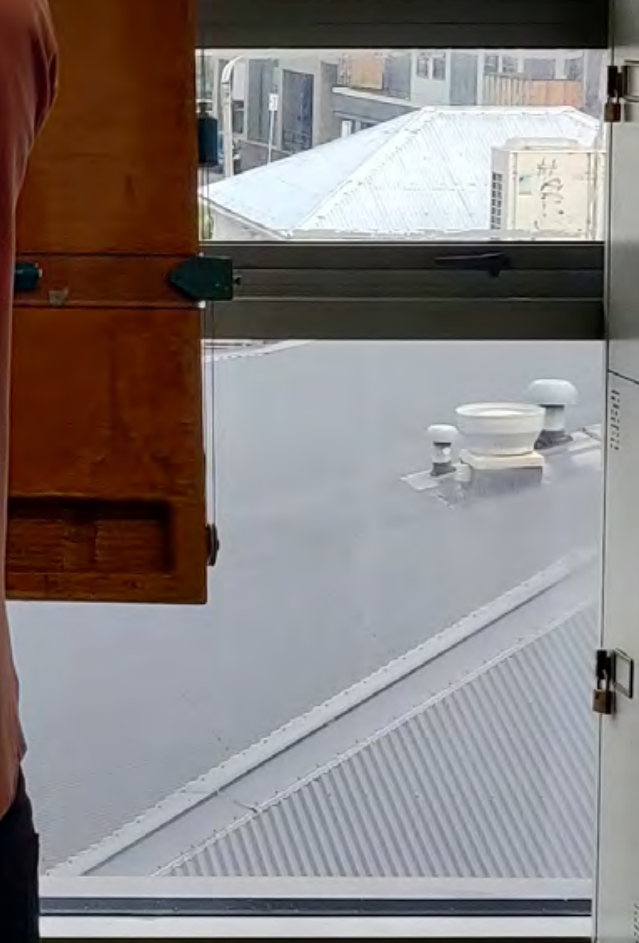

PROLOGUE

It was at this point in the research where Türangawaewae proved a fitting name for the thad come to most fully recognise thesis, as it ultimately involves the establishing of the provocative real-world issue posed by the visible final remains of the Te Aro Pā-preserved and locked away beneath the Bellagio Ataahua apartments. I saw the contemporary design of thes of engagement with the $\mathrm{p}^{\mathrm{a}}$ context-throughout the entirety of the building concept-led to them becoming all but invisible within the surrounding urban environment. I drew links with the land beneath this building and my own lost cultural identity, where this site invited an opportunity to engage the undiscovered side of my cultural heritage. With its modern context situated around preserved fragments of the Te Aro $\mathrm{P}_{\bar{a}}$, this site simultaneously was recognised as an opportunity to test develop and refine the methodological approach from Codex 01

identity of place, through an understanding of the whakapapa (genealogy) intrinsically connected the land. Codex 01, Te Kore, drew inspiration om the paintings of Māori artist Shane Cotton as well as relevant European sources. Codex 02 , Te Ao Marama, shifts its focus further towards Maori narrative inspiration, transitioning from the primarily Westernised provocations of Codex 01 and reapplying these in relation to mātauranga Manori- the body of knowledge originating from Mãori ancestors, including the Māori world view and perspectives, Māori creativity and cultura practices"(Māori Dictionary)

To arrive at the Concept Design and Preliminary Design outcomes of the investigation, Codex 01 explored the thesis proposition through three stages referred to as Inception, Cognition, and Activation. The name for the thesis, Tūrangawaewae, was Codex 02 repeats this essential cycle once more selected to acknowledge the importance of 


\section{CHAPTER 05}

66

Te Pō, Te Whaiao, Te Ao Mārama. From out of the darkness, the world of being, to the world of light.

rom out of the darkness you come and you have to do something -Te Whaiaoliterally chase the world of being.

- Cliff Whiting, in interview "Te Po, Te Whaiao, Te Ao Mârama (From out of the Darkness, the World of Being, to the World of Light)", np.

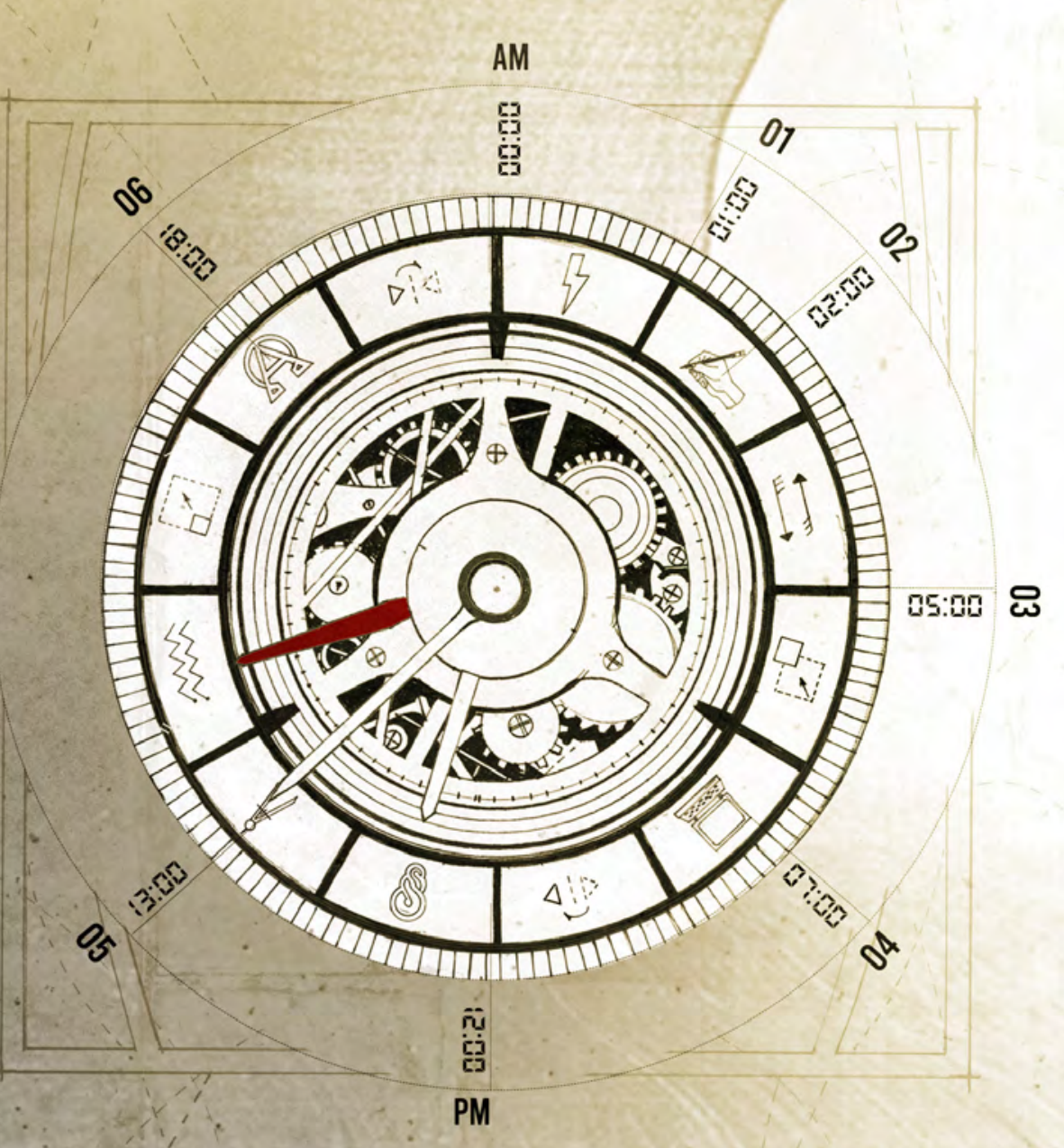

TE POUTŨMĀRŌ | THE PINNACLE / MIDDAY 
You suddenly realise you are something and have to act and enter the world of light. This is the pattern for creative processes. There has to be that first step, the the second one, and the third one. It is a continuous pattern that goes through everything.

-Cliff Whiting, in interview "Te Po, Te Whaiao, Te Ao Mărama (From out of the Darkness,

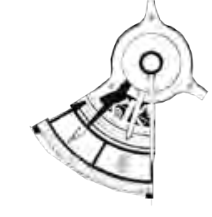

TE POUTŪMĀRŌ | THE PINNACLE / MIDDAY

Chapter 04, "Te Poutūmārō Midday", represents the Developed Design Stage of the investigation. It is divided into five sections:

5.1 Method \& Processes builds upon the processes explored in Codex 01 to help address the Research Question.

5.2. Contextual Analysis presents the topographical and historical contexts for the research site used in the Developed Design Stage of the thesis investigation.

5.3 Literature and Project Review critically reflects on theorists and case studies that provide a foundation for the design-led research experiments in the Developed Design Stage.

5.4 Culmination: Developed Design uses the re-design of the Bellagio-Ataahua Apartments at 39 Taranaki Street, Wellington as a vehicle for advancing an allegorical architectural design $n$ the final Developed Design Stages of the thesis investigation. This section is divided into three subsections: Inception, Cognition, and Activation.

5.5 Critical Reflections reflects upon the design outcomes in the Developed Design Stage of the thesis investigation. 


\subsection{METHODS AND PROCESSES}

the Developed Design Stage of the thesi investigation. In acknowledgment of the cyclical

understanding of time in te ao Māori, this codex Cognition then functions as the blurred zone where repeats the journey through the allegorical architectural method developed in Codex 01providing an opportunity to develop the thesis argument through the final application of theorist, case studies and provocations. To arrive at the Concept Design and Preliminary Design outcomes of the investigation, Codex 01 explored the thesis proposition through three stages referred to as Inception, Cognition, and Activation. Codex 02 repeats this essential cycle once more-bringing together all three Research Objectives - this time vealing and critically reflecting on the Developed Design outcomes of the investigation.

The site for the Developed Design outcome of the thesis is 39 Taranaki Street, where preserved emains of Te Aro Pā are displayed beneath the Bellagio-Ataahua Apartments. The chapter begin with an introduction of Kaupapa Kōrero, the Māo translation of genealogical narratives that helps to establish Tũrangawaewae. It then reflects on an oral narrative-based contextual analysis, when site visit from a local Iwi representative provided invaluable insights into the contextual heritage narratives relating to the site.

The Inception stage begins with the introduction of two key provocations sourced from the realm of matauranga Maori. Initially these provocations are translated through a multilayered speculative han drawing experiment-forming Inception: Desig drawing ex the design is transitioned from drawn allegory to designed allegory, engaging both battle and progress in the formation of the concepts. The taxonometric drawing method is enployed in the early stages of design, where it is utilised to engage ath allegory and cortext within the developing and and reflect on the dialectic of heritage site an contemporary architecture-forming Cognition esign Stage 04.2

Activation, the final stage of this Developed Design chapter, provides the fulfillment of the realised architectural solution. In this section, the allegorical project is transitioned from the realm of the imagined into the realm of the pragmatic. The design is envisioned as a solution for an apartment hat challenges and identifies space and occupatio in regard to concepts of site and heritage. This stage functions as a description of the final allegorical architectural outcome, conmunicated through and Annotations, culminating within a single static drawing-Activation: Design Stage 4.3, the fina outcome of Developed Design.

The entire cycle from Inception to Cognition to Activation in Codex 02 is called Culmination, which appears in Section 5.4 . axonometric layering of Denotation, Connolation 
The orator's speech is considered to be a re-enactment of Täne separating earth and sky, the means by which light came into the world..

If the orator's words offer guidance and wisdom, he brings his audience out of the 'night" of conflict and into the 'day' of peace and resolution. This occurs when mana (a spiritual force) enters the person - just as the sun illuminates and brings forth the new day

\footnotetext{
- Te Ahukaramü Charles Royal, "Te Ao Mărama - the Natural World"', np
} 5.1.2 KAUPAPA KŌRERO In Māori culture, framework positions individual stories within ascribed to the repository of knowledge, where layering of kōrero and kaupapa that has shaped they are used to facilitate the process of knowing each person's individual story (Ware et. al., 49). and learning. In the article "Kaupapa Kōrero: a Māori cultural approach to narrative inquiry", the authors explore the notion of kaupapa kōrero as a means of applying whakapapa (genealogy) to identify personal kōrero (stories) and "integrating them within layers of interrelated kōrero about their whānau (family), te ao Māori (Māori culture) and society that influences contemporary experiences of being Māori” (Ware et. al., 45).

The word kaupapa, stemming from 'papa', translates as the base and foundation for understanding, knowledge and action. Kōrero refers to conversation and the expression of houghts. Kaupapa kōrero represents a narrative approach as it is based on the Māori tradition of ora rans f spiritual, historical, social, cultural and politica Māori experiences. When applied in reserch, kupa kōero is a Māori approach to narrative that allows for the gathering of fundamental kōrero and the citical represtation and understan of these stories. The application of the whakapapa

The act of telling one's story is powerful and can increase reflexivity, resilience and personal agency Kaupapa Kōrero offers an important insight into the actual real lives of the participants and understandings about how they see themselves and how they want to be seen and defined by others.

— Ware et al, "Kaupapa Kōrero: a Māori Cultural Approach to Narrative Inquiry", p. 45.

Codex 02 implements this approach of kaupapa kōrero, providing an alternative method of andysis, attempting to establish a cayered genealogical understanding of the Tarana Street site. This method invites the translation of whakapapa through a symbolic and allegorica architectural narrative, where stories are transhed pecificlly in rela to the senctogical f epresentation of ploce ilention, infoming formation of a place to 



\section{C6}

It's almost impossible to express how important this is to Mäori... We know our own stories - they're articulated through our oral traditions - but to have this find is truly special. It just reinforces that the history of Wellington - and the rest of New Zealand - is not just about buildings, but also about Mãori heritage, which is just below
the surface.

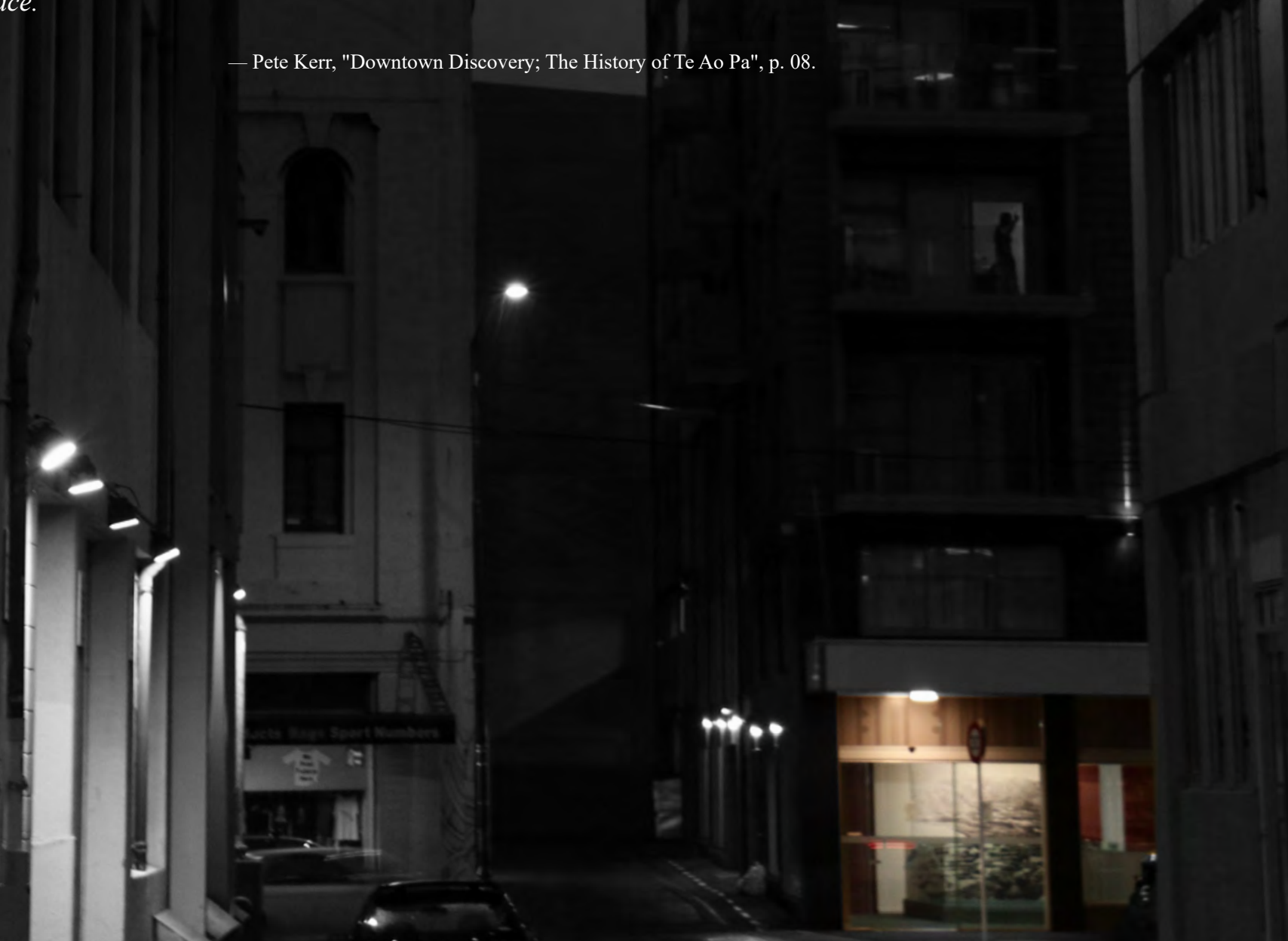

B: 4 I Pm

Opposite | Figure 5.02. 'Te Aro highrise', Digital Photograph.
Author's Image

\subsubsection{THE SEVERED SITE}

storey highrise in the heart of Wellington was suddenly halted by the discovery of a 160 -year-old pā site during the construction of the building's given it had been concealed by another building for over 100 years. For local Māori, this discovery was hugely signifigant, representing one of the few remnants of a pre-European occupation of New Zealand (Kerr, 5). Since the construction of the Bellagio Ataahua Apartments, the site and the architecture that occupy it have become a subject of both multiple criticism and discussion.

Initially, in its construction phase the discovery of the lost pā quickly evolved into a huge challenge for Washington Development Limited - which had already spent the previous two years gaining resource consent. The discovery of the pā led to the council withdrawing their consent, stalling the project indefinitely. This was followed by a perio of mediation largely involving the developer with their financial concerns, and the local iwi who were wanting to take guardianship of their heritage (Kerr, 5). In the following 18 months, these two dispar, groups combined with the council's interests, worked through their considerable differences, finding a common ground where both paties were satisfied. Due to this common ground, the developer had to work through major design developments in order to protect the fraile $\bar{n}$ remins. This involved redistibuting apartments, structural foundations, relocation of the car park, 列 and display the ruins. As a result, the building was increased in height by two stories as a concession thelp compensate for the developer's loss, and the (round floor entrance was converted into a public vestibule - with the remains of the pā preserved in glass encasement-where the public are able to view them. David Dowsett, owner of Guardsman Property Management Ltd, is credited by many Pis efforts to preserve the remains of the $p$ with the New Zealand Archaeological Association presenting him with its Public Archaeology Award (Kerr, 5)

Since the completion of the building phase, the architectural solution has received a mixed response from the public. Below is a comment taken from he local Wellington urbanism blog Well Urban:

It's clearly not a work of architecture: it's maximum allowable volume diagram with some balconies slapped on.... if only the building could have exhibited the merest whisker of grace, elegance or imagination. Wellington doesn have many physical traces of pre-European occupation, so retaining the pa remnants was essential but surely there was a better way tha this. It smacks of archaeological blackmait: "Give us some extra storeys, or the whare gets it". - Tom — Well Urban, "Nightmare on Taranaki St", np. 


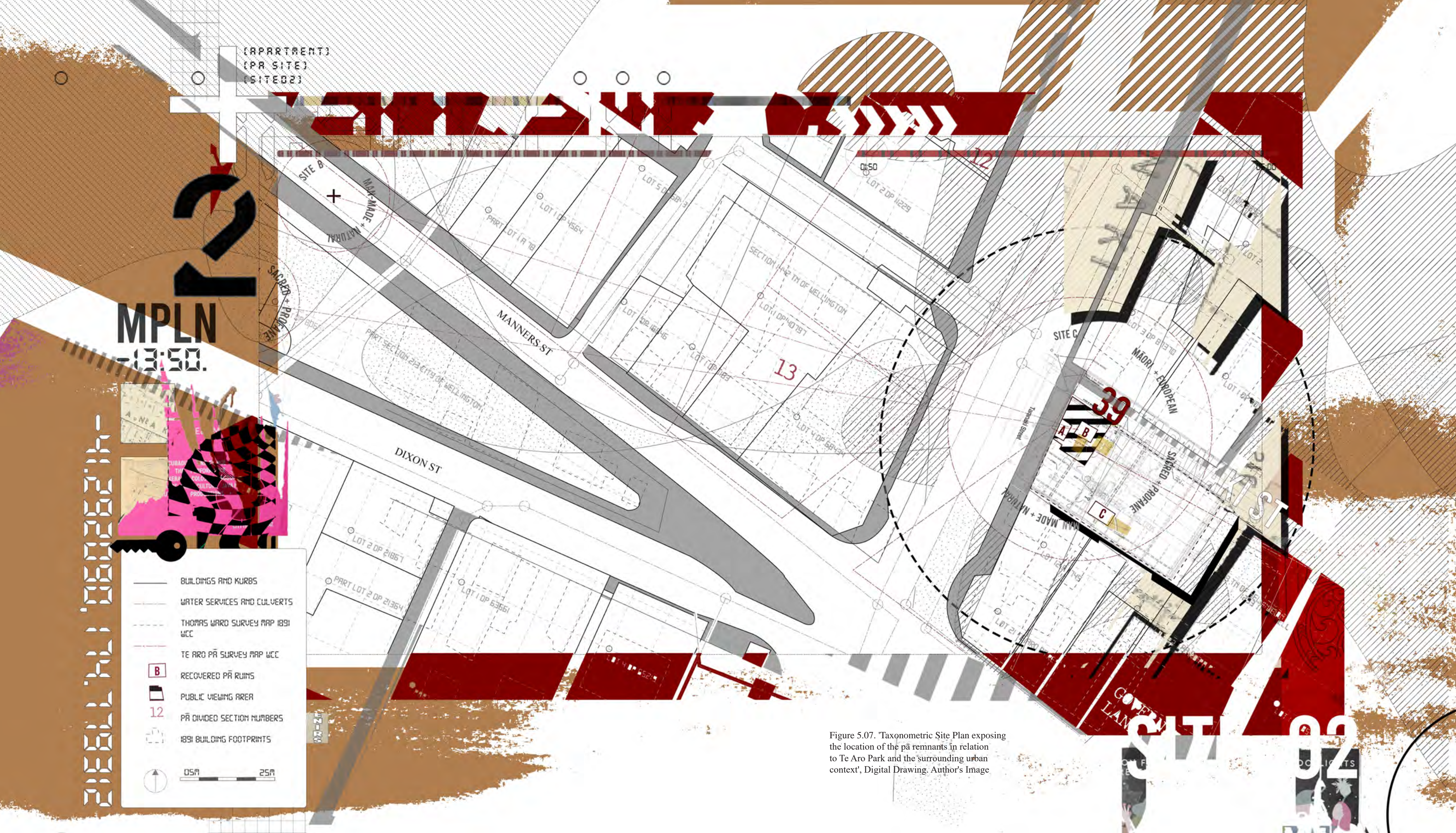


This [räkau whakapapa] represents the flow of ancestral power (mana) along a particular line of descent from the divine ancestor (atua) down to the living holder... used as a memory aid for the orators when recounting their genealogy (whakapapa). Each projection on this staff represents a generation related to its owner.

- Jenny Newell, “Pacific Art in Detail”, 2011, p. 64-65.

\subsection{LITERATURE AND PROJECT REVIEW}

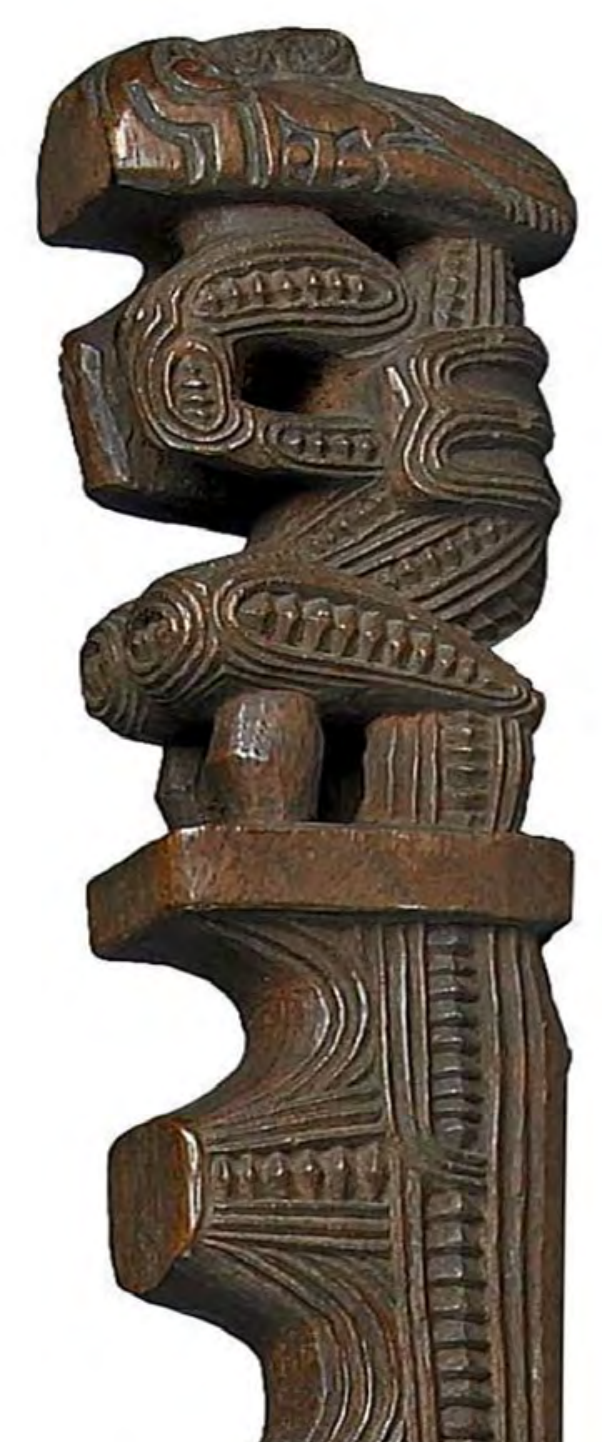

5.3.1 SYMBOLIC PROVOCATION In order to through the kinship associated with whakapapa develop upon (Newell, 64).

relevant methods and provocations from Codex 01, a

new provocation was selected to assist in advancing The concept of this rākau whakapapa is explored the Developed Design stage of the thesis, which and applied in the following experiments, where it is relates to the establishment of a Māori inspired used to inform an allegorical architectural drawing notion of place. The rākau whakapapa (orator's red to intorm an allegorical architectural drawing mnemonic staff) was identified as a relevant identity. This approach provides an opportunity allegorical provocateur, holistically bringing to critically reflect on the heritage stories, both together kaupapa kōrero, oral narrative, and good and bad, which have led to the current genealogy within a physical symbolic object. The situation of the apartment complex, translating

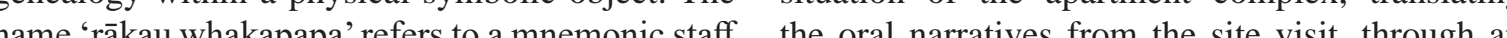
used by the orator of the tribe during teachings. The allegorical architectural exploration. This method notches of the staffeach represent the ancestors who of interpreting context invites critical engagenent form the tribe's genealogical heritage- with each with the site, allowing one to analyse the complex notch representing a new generation of ancestry. layering of stories that have manipulated the The staff is used during teachings, as the orators landscape's current form. It sipultaneously move their honds along the notches and recite their arranges these stories within an interconnected whak Symbolically, the staff provides the allegrical framework, positioning each in rator with a connection to the earth from which to a temporal concept of contextul heitethey belong as well as a support for standing. providing critical insight into the foundation The raik whake symbolic foundation for Türangawaewae, defining landscape's shifting identities. the orator's right to stand, reside and belong 


\subsubsection{FINE ART PROVOCATION}

\section{SHANE COTTON} staff-communicating a narrative of time and

We need to speak to the 'hearts and minds' of ordinary people in order to change our species 'conduct. We have to rekindle the spiritual link to the environment that pre-industrialized and pre-secular peoples took as the norm. What we need ro recognize is that phengh on modern liberation we have become dangerously desensitized to the working model that nature established long before our species hit the ground running.

- Anne White, in Mircea Eliade's The Sacred and the Profane $e_{2}$ p. 115 the rākau whakapapa as a symbolic provocation, a Māori fine art provocation was also selected for its relationship to the developing allegory of site.

MIDDLE NORTH (fig. 5.09) was selected for its parallel relationship to the rākau whakapapa, where the staggered branches of the potted tree fern were interpreted transformation. The vertical line down the centre of the drawing defines an initial 'confrontation', an allegorical battle, expressed by the Māori symbol of life (tree fern) on the left, and the contrasted colonial lettering on the right. Parallel lines appear as a series of horizon lines, as branches of the fern, signifying the passing of time-with the lower lines reaching into the ancient past and the upper lines into the unknown future.

to signify a fire pit, the symbol of occupation and Turangawaewae; secondly it is a registration mark, indicating the two overlapping worlds comin together; and finally it is a symbol of Christianity,

The right side of the painting can be interpreted as the collision of the Māori world with the colonial era. A rectangular brown shape depicts the notion of land as a sectioned cliff- - a notation for the
reshaped, surveyed colonial world. The date appearing at the top of this cliff signifies a poin of perilous transformation in the political world, the year after the very first MMP (Mixed Membe Proportional) election. The letters on the branches of the fern, Te Tai Tokerau, show the name of the New Zealand parliamentary Māori electorate th was created out of the Northern Māori electorate.

Five rings are shown linked together, but hanging perilously from the edge. This notation represents the five Māori electorates of the northern regio that have united. The viewer must wait to see if they can hold on during this collision of time and transformations.

The left side of the fern could be interpreted as the Māori era, where a brown shape depicts Cotton's painting can be re-interpreted in the thesis for the landscape, providing valuable symbolic insights towards representing a genealogical place identity in relation to the symbolic allegorica precolonial Māori world The upturned ba Mãori as a result of the collision with the European world The small cross on the far left is a notaion device representing three important concepts: firsty, it is a sign used by Coton in other 


\section{SHANE COTTON}

\section{CROSS}

another case painting Cross is of Māori identification with place identity. The potted fern in Cotton's Middle North (fig. 5.09a) as well as the vertical tree in Cotton's painting Kenesis (fig. 2.05). The caption below Cross in the Aucland Art Gallery Toi o Tāmaki confirm that the vertical black line represents "a stem, the manawa ora (breath of life) connecting whakapapa (genealogy) and land" (Aucklan Art Gallery). This painting also uses simila

Figure 5.09a. Shane Cotton, Cross, 1996

Ko te poutū o tênei peia he tumu, te manawa ora e hono ana i te whakapapa me te whenua. Kúa mahora te peita ki te kōkōwai hei tohu mò te tangata whenua o te taico kawea ai te kaupapa o te ahi kā: ngāa ahi e whakaatu ai i te hononga ki te whenua.

Here the painting's vertical can be read as a stem, the manawa ora (breath of life) connecting whakapapa (genealogy) and land Suffused in a rich kōkōwai (red ochre) symbolising the tungata whema (people of the land) within the landscape, the English word 'Light' in Gothic script on the loft, while to the right is the Mâori word 'Ahi', which vertical centrelise is reminiscent of the vertica Atlegorical storytelling devices as the Surrealist painting case studies: painting case studies:
Threshold: The thick black vertical in the centre of the painting can be understood as a threshold, with the colonial era on the left side and the Māori era on the right. This is suggested by the (is

Mirror: To the right is a square image of a mountain, while to the left a similar image is
inverted. This is reminiscent of the duality of a mirror-again with the colonists allegorically on

the left and the tangata whenua on the right.
Frame: The images of every mountain are always is contained within a square frame. Nature is being controlled, rather than free.

Dance: The white elements growing, curling, and escaping from the black vertical threshold end up in knots, almost as if engaging in a dance. They re natural, growing, fluid in their movement, alive.

Mask: The entire canvas is covered in kōkōwa (red ochre) and a grid of small fires. In a sense, his is a mask that represents the tangata whenu (people of the land) covering the entire painting. while at the same time the square grid represents the coloniser doing the same.

Cotton's allegorical use of the symbol of ahi à is particularly relevant to this investigation. "The painting conveys ahi kā: the burning fires of continuous connection to the land" (Auckland Art Gallery). The 'continuous connection to the and' is at the heart of Türangawaewae, our place stand. In the Developed Design outcomes of he thesis, a fireplace representing ahi kā connects every level of the Apartment Block. 


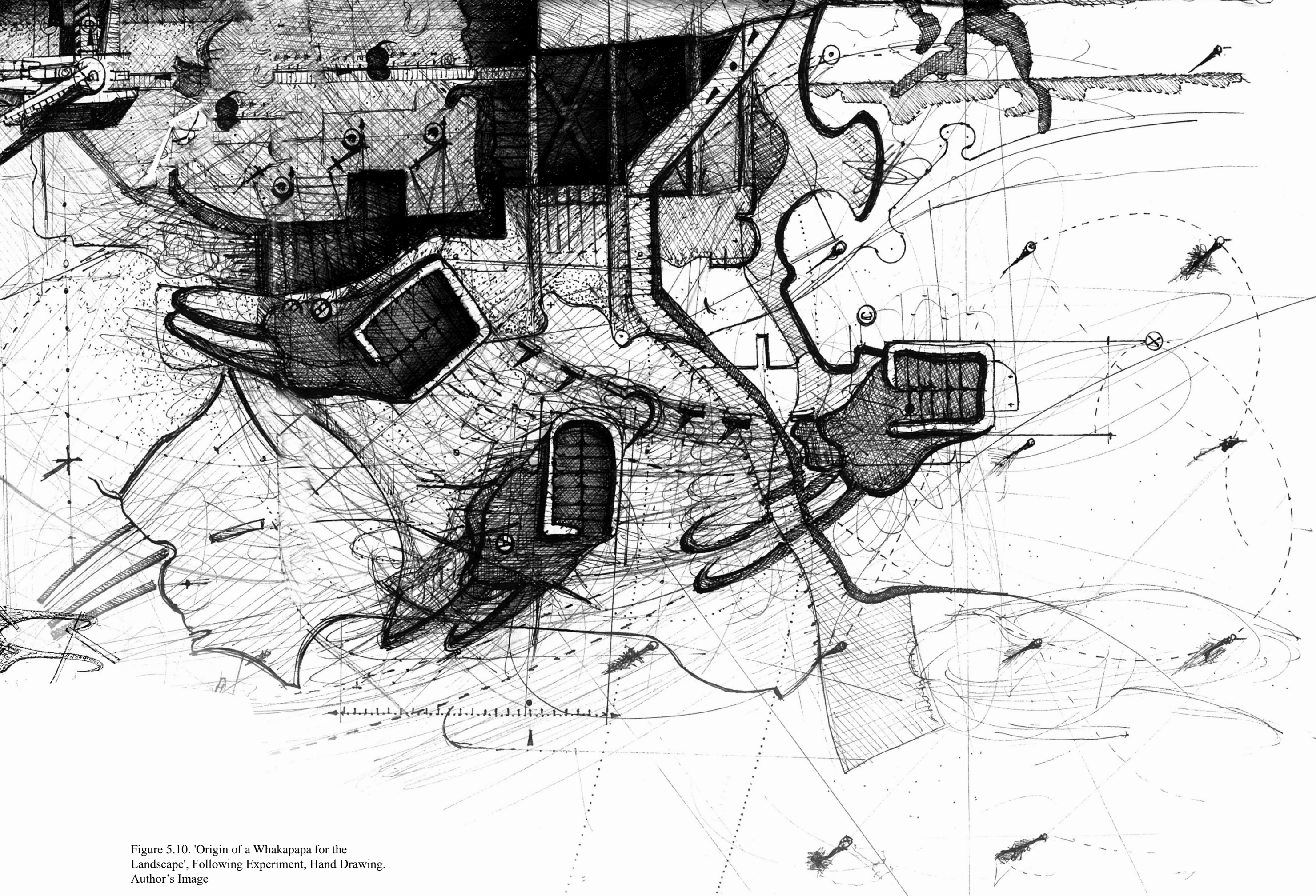

Ko Ngāti Ruanui te iwi.

Ko te Matau-a-Māui taku Türangawaewae.

Ko Jonathan Morrish taku ingoa.

5.4 CULMINATION: DEVELOPED DESIGN TÜrangaWAEWAE A PLACE TO STAND

Section 5.5, Culmination, brings together the Developed Design outcomes, these are divided into the three sections of:

5.4.1 Inception

5.4.2 Cognition 


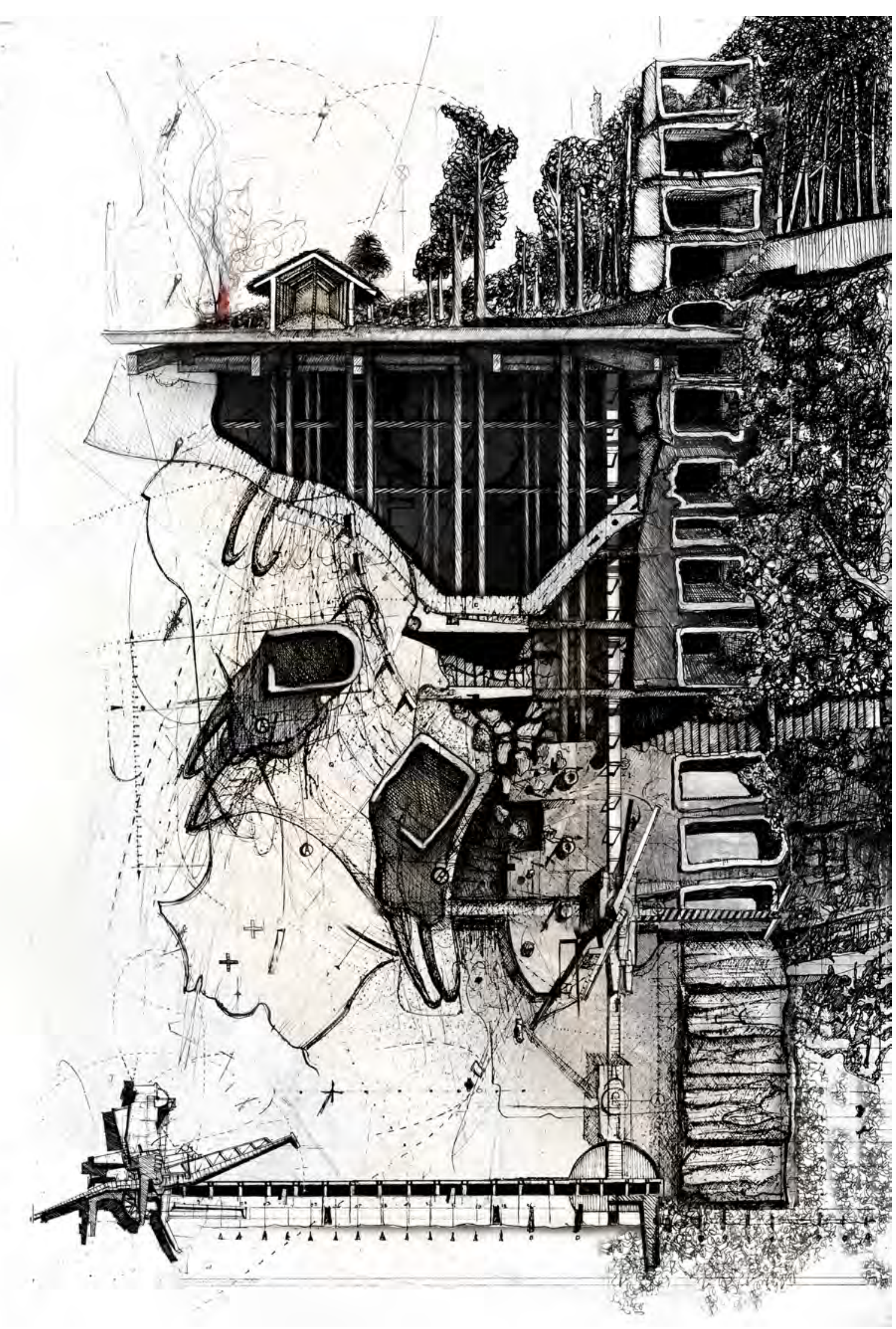

5.4.1 INCEPTION:

TÜRANGAWAEWAE A PLACE TO STAND

5.4.1.1 PRE-COLONIAL Inspired by Shane Cotton's symbolising Māori occupation of the land-this painting depicting the reflects the use of Cotton's crossin Middle North (fig. confrontation between European and Māori 5.09) and ahi kā in Cross (fig. 5.09a)-becoming a worldviews, the first concept drawing for 5.4.1 potent symbol of Türangawaewae. One of the whare Inception, (fig 5.11) is inspired by the rākau also appears in section, where the timber structural whakapapa. It explores an identity of the land in foundation of the land is revealed - supporting the the temporal era just prior to colonisation, and whare above it. This foundation protrudes through the second concept drawing (overleaf) depicts the ground plane becoming the towering trees this identity in the era following colonisation and surrounding vegetation characteristic of preThis results in an allegorical depiction of some European Wellington-an allegorical reference to of the fundamental temporal transformations that the symbiotic relationship between the land and of the fotrod to the current site context beneth the Maori. The void in which this structure exists is apartment complex the fluid Waimapihi Stream, emerging from beneath Down the right edge of the first drawing appears the the rākau whakapapa.

rākau whakapapa of the landscape, the mnemonic timeline, which establishes a geneanonic representation of context. This rākau whakapapa timeline; its linear nature implies a Westernised appears in plon in the lower layers, shown as concept of time. Upon this timeline, a mechanistic weathered timber notches indicating foundation entity appeas in elevation - occupying the initic of the staff layered in time. In the upper layers, point of origin. This entity is also seen in plan, he staft is cut in section, becoming enpty voids where the timeline becomes vertical disapearing waiting to be filled a limpse into the future into the void beneath the earth. The entity functing The centra section shows thee of these segnes as the are The clly fled, indieting the progress of time in experin the allegol

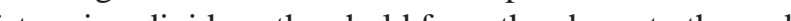

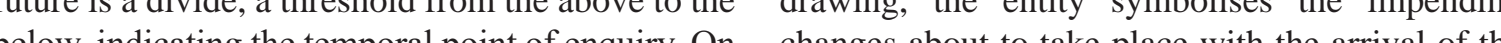
be plat in plan, reminiscent of the notched segments of the away at the foundation of the lants 


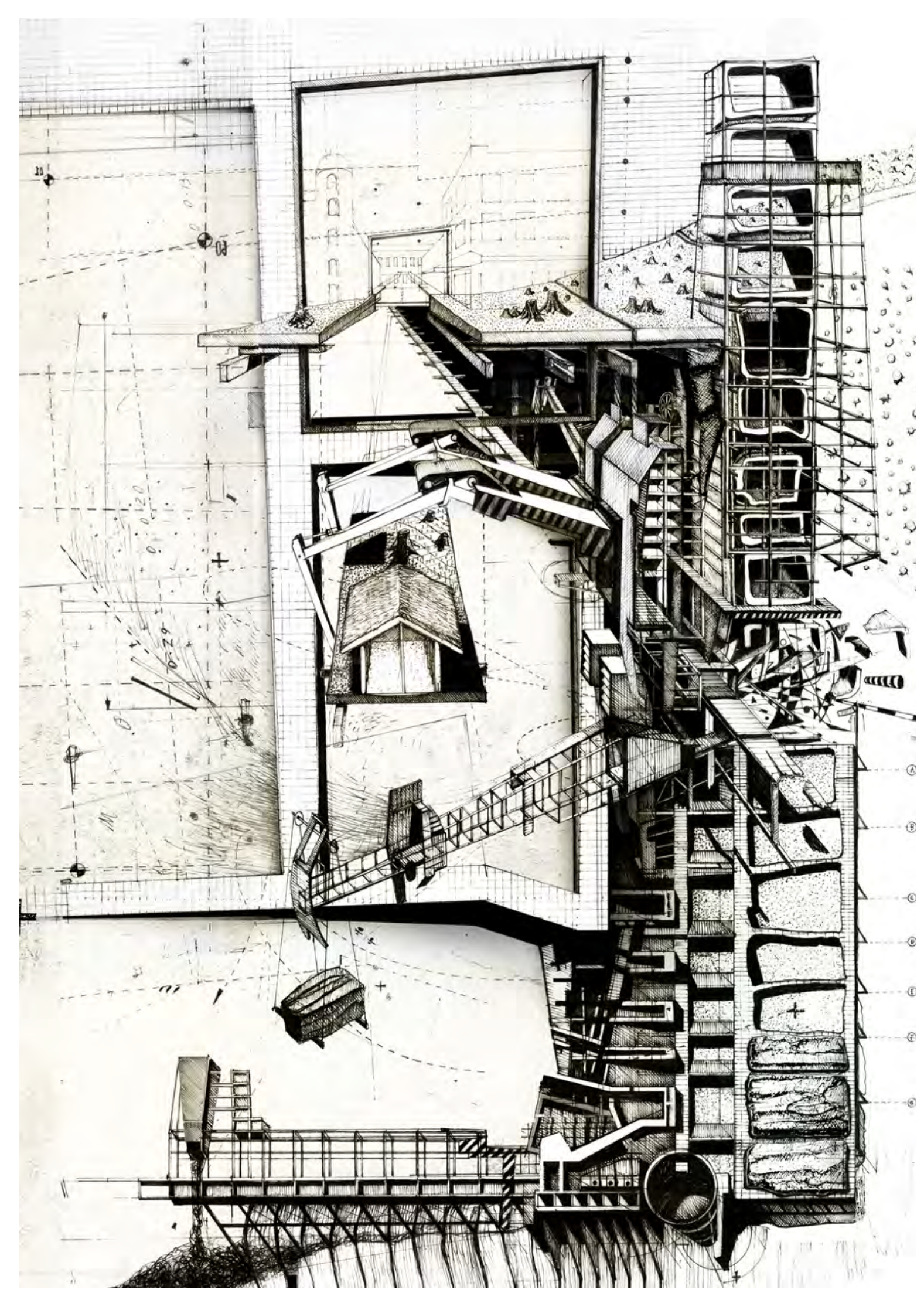

5.4.1.2 POST-COLONIAL The second concept drawing to the European allotment of space. The segment (fig. 5.11a) for Inception is that the whare previously occupied is seen being also inspired by the rākau whakapapa. It involves removed and relocated by the architectural a depiction of the land identity in the era following narrator, allegorically alluding to the European the collision of European and Māori culture. In this desire to relocate Māori from their original home. drawing the same rākau whakapapa is depicted The surrounding landscape is depicted naked, with down the right edge of the page; however it has all its resources stripped, contained and taken, with undergone major transformations since its previous with the arrival of the settler. The foundations depiction. A compositional shift occurs, where the beneath the landscape can be seen shattering as a defining line of the drawing hifts from the right to result of the effect, symbolising the transition away the left edge, indicating a flipping of the previous from a symbiotic relationship with nature. A cross composition caused by a shift in time. the European cross as a sign of Christinity, which In the lower levels, segments of the genealogy have came with the settler-a blurring of symbolisms been lifted and removed, placed by a crane-like inviting interpretation.

che ordertoreclaimteharbour. The dynamicmovement - crane - removing segments of heritage - which the narrator exists upon, disappears towards has resulted in a fracture of the timeline, depicted a perspective vanishing point. This provides a as an explosion that has severed the mnemonic small glimpse into the future where wireframe taff in two. The upper levels of the staff become depicions of Victorian architecture indicate the solat, held up only by the net discon, hect un discins oring

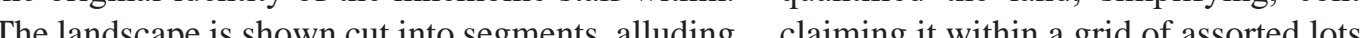


"TŪRANGAWAEWAE - A PLACE TO STAND"

am Ngăti Ruanui. I am Pakeh

lam 24 and a student studding allegorical architecture
see my ancestor throuby the len of

And who I will always be.

My ancestor is my whakapapa.

My ancestor is my embedded conding back in time.

My place to stand

My ancestor is my rākau whakapapa.

rakau whakapapa stands

Next to another răkau whakapapa,
As if seeing its own reflection in a mirro.

The left side of the drawing shows the rākau whakapapa

Prior to the arrival of European settle sis.

The right side of the drawing shows the ravkau whakapapa
Afferwards - two cultures together, yet remaining separate

This drawing is my dual rākau whakapapa.
This drawing is my ahi kā, my continuous connection to the land.

This drawing is my "Türangawaewae".

My Place to Stand
占: 嵒 㓷

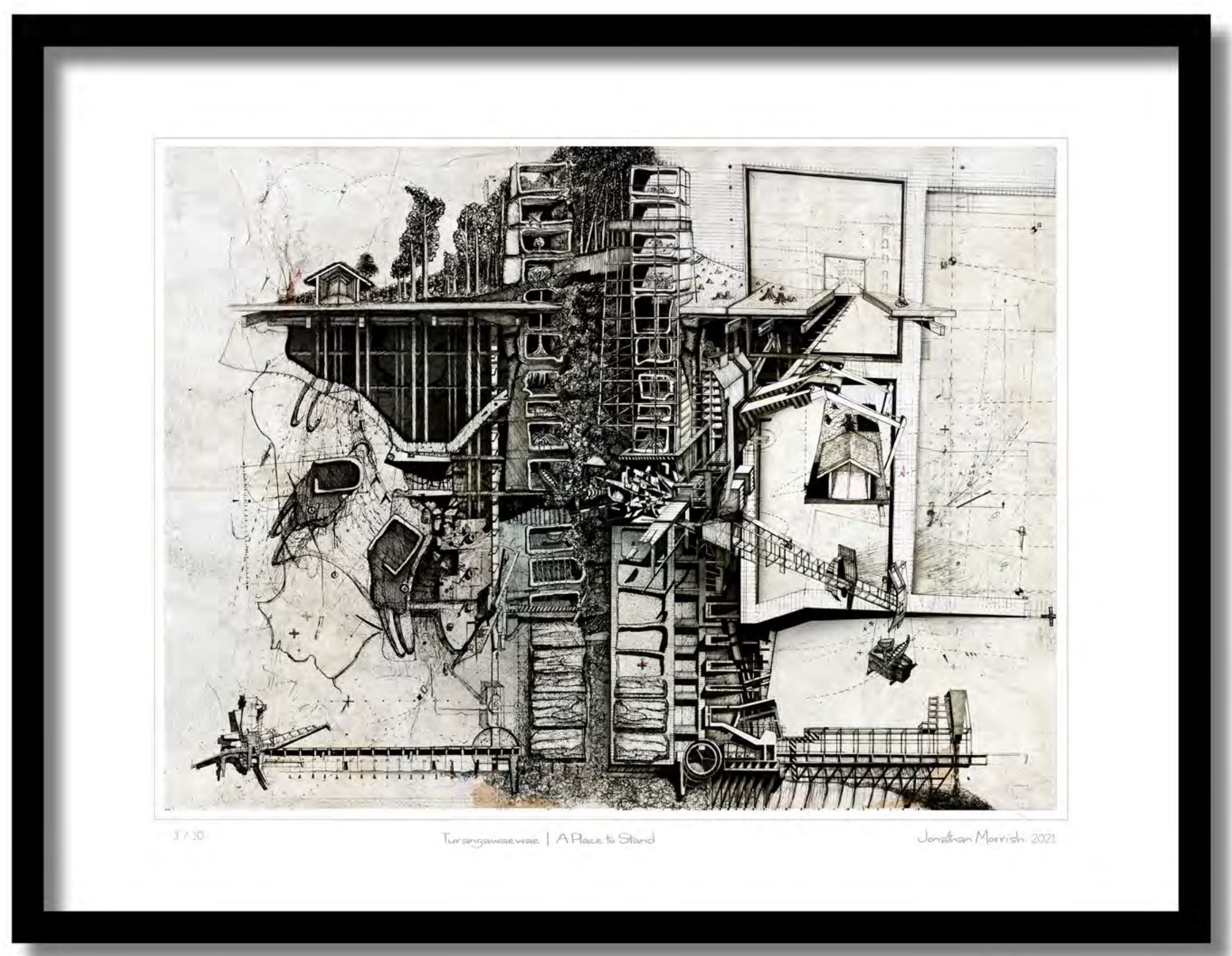


迆: 05 P P

66

This desire for the "ideal" envisions a programme beyond utility,

demanding a universal interpretation of architectural metaphors. To draw

architecture or to build architecture is ultimately the manifestation of the

ranslatability of a poetic text of metaphors into architectural form.

- Raimund Abraham, [Un] $]$ built, p. 101

5.4.2 COGNITION: 


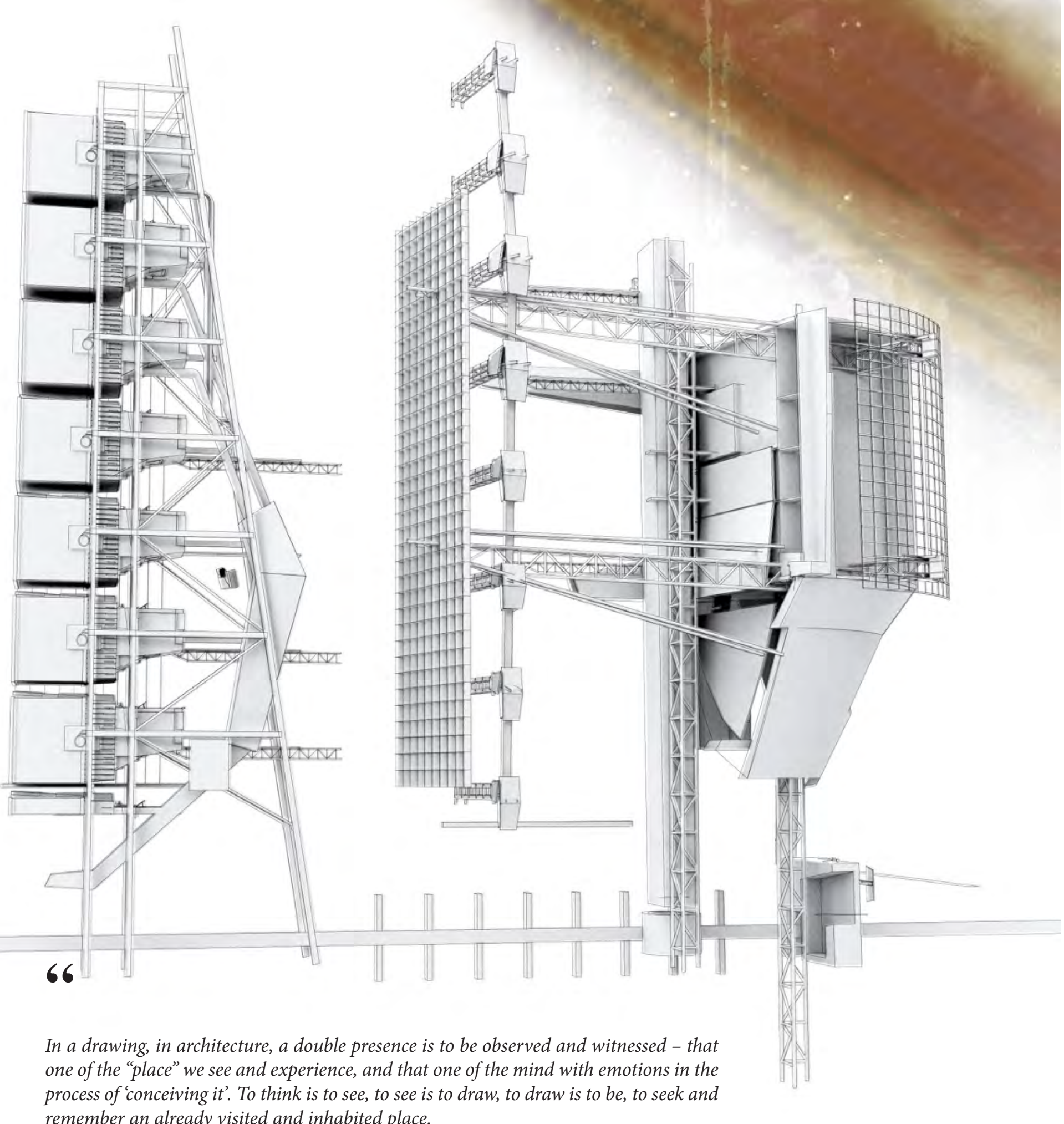

process of 'conceiving it". To think is to see, to see is to draw to draw is to be to sin the remember an already visited and inhabited place.
占: $15 \mathrm{Pm}$
Figure 5.16. Architectural Development and
interpretation of the Figure 5.13 Concept draw Interpretation of the Figure 5.13 Concept drawing,
representing the rākau whakapa (left architectural intervention) in a confrontation with the narrator (right architectural intervention). Digital Drawing.
Author's Image
The 'Cognition' begins with the formation and design of two principal interconnected architectura identities - informing an initial confrontation an allegorical 'battle' (fig. 5.16). In this experiment, site is manifested through the development of a metaphorical rākau whakapapa, derived from fig. 5.13 in the previous Developed Design Stage called Inception. The left architectural intervention in Figure 5.16 represents an architectura interpretation of the mnemonic staff, the rāka whakapapa. It functions as the guardian of the site's narratives-alluding to the temporal layering of heritage narratives that have shaped it. The opposing architectural counterpart on the right represents the narrator, also adapted from the Inception stage of Developed Design. This narrator communicates its allegorical narrative through a dynamic mechanistic architectural language- - derived from the previous stages of design for the public toilet block and the bus stops. The 'mechanical' language highlights both cause and effect of allegorical forces in relation to the revealing and physical manifestation of the landscape's whakapap implementing a figurative geometry derived from Pullman's allegorical concepts of the Silver Guillotine and Dæmon cages, which were explored in the Concept Design stage of Codex 01. The following drawings depict the development of this design as it transitions from an allegorical foundation into the taxonometric representation. 


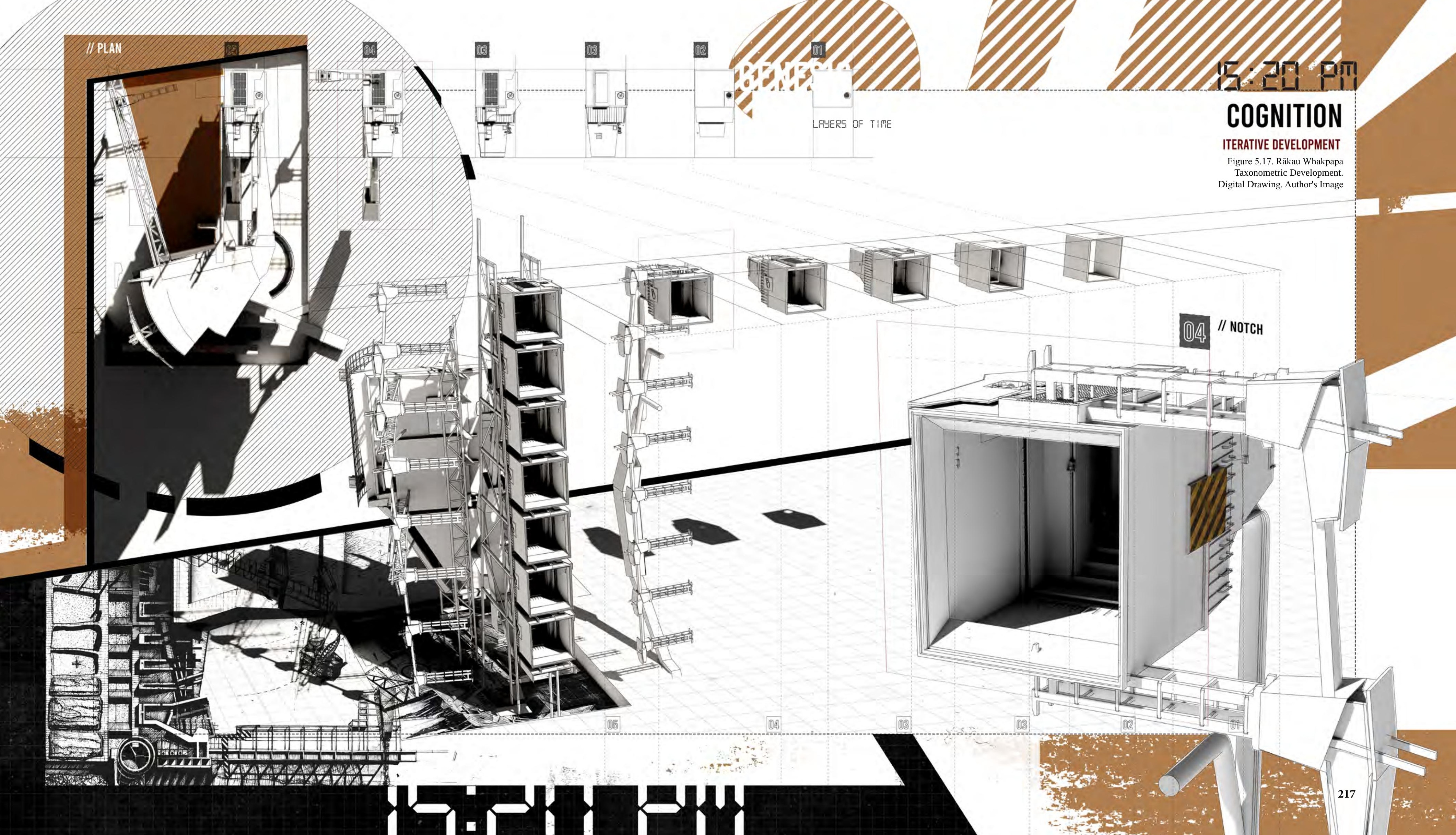




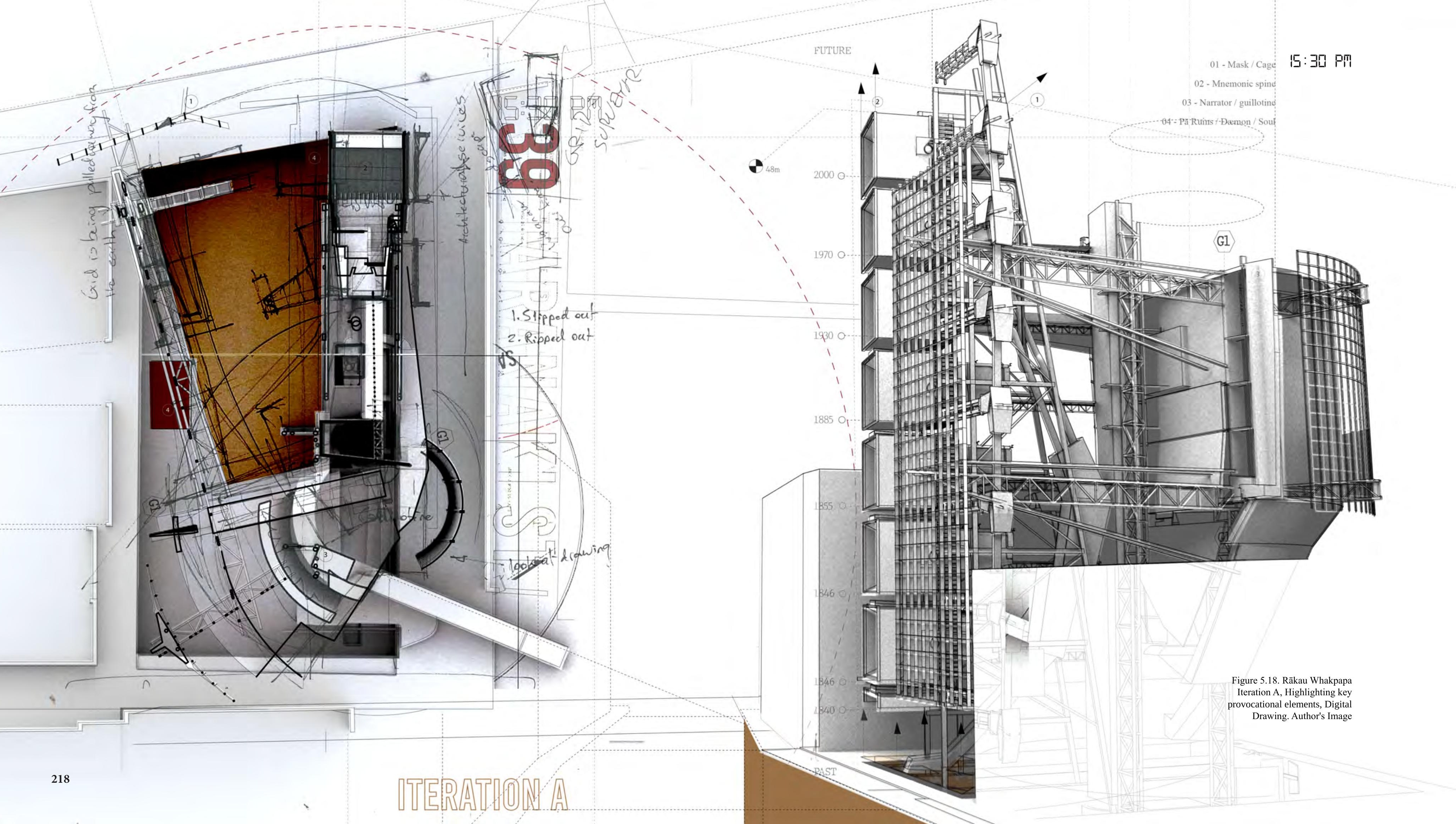




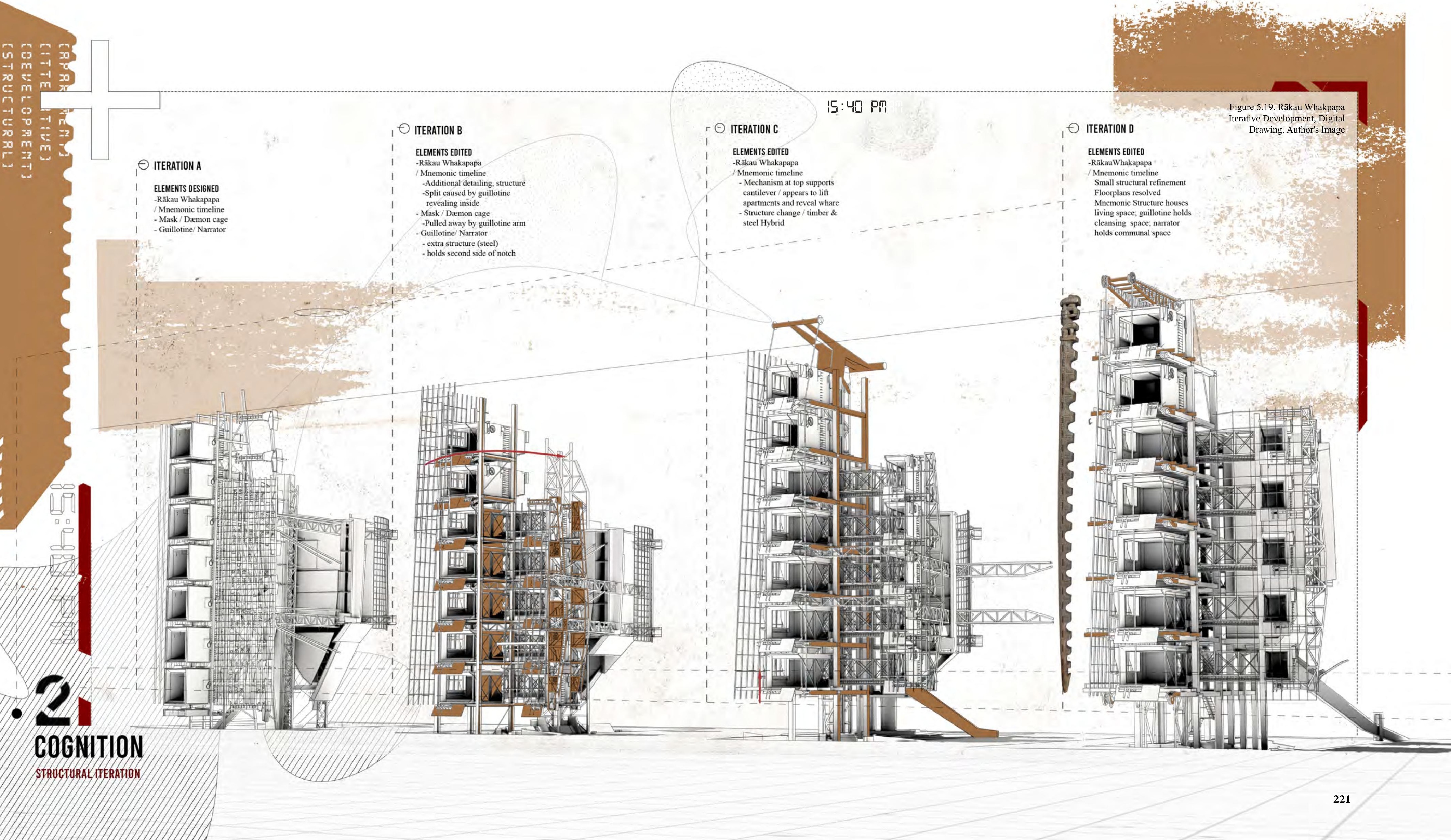



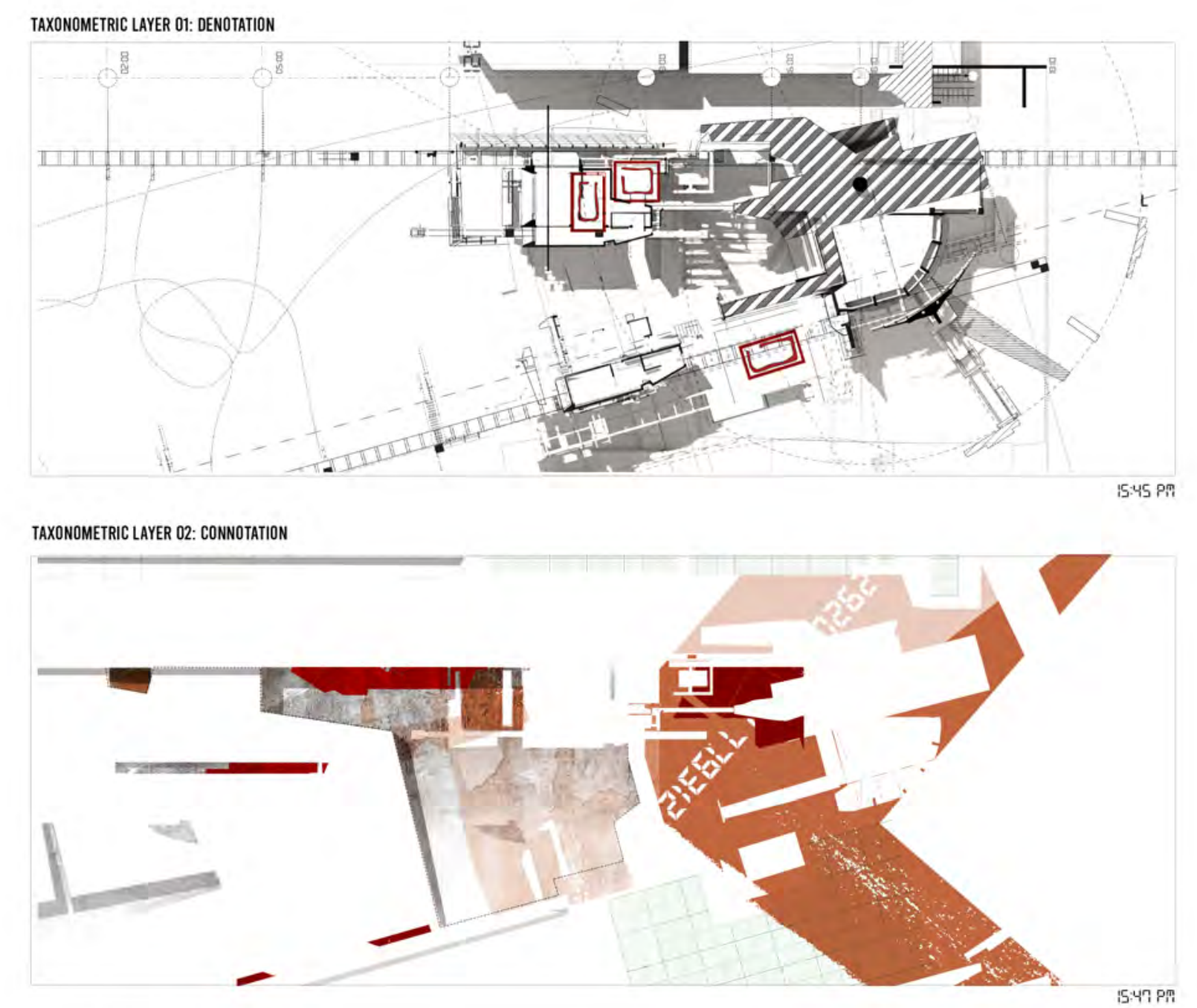

drawing (fig.5.21 overleaf) aims to articulate the initial split resulting from the collision of site and architecture. This is manifested by the silve guillotine's cut, the divide that leads to a division of sacred and profane elements. This action reveals the remnants of the pā in the layers beneath through its dynamic sweeping nature. In fig. 5.20, this Taxonamic so

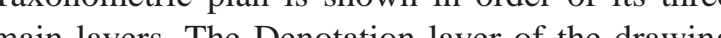
appears as the designed architectural elements of pration D; the Connotation then appeas though he collisions and collisions for the collision the medition of the allegorical the chieve a symbiotic culmination, providing key hints to deciphering ulterior allegorical concepts 


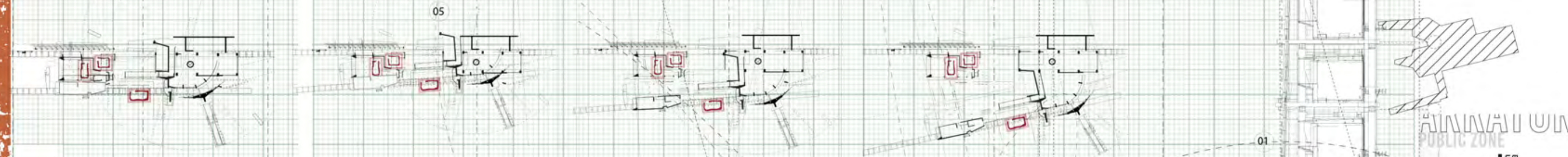

(1)

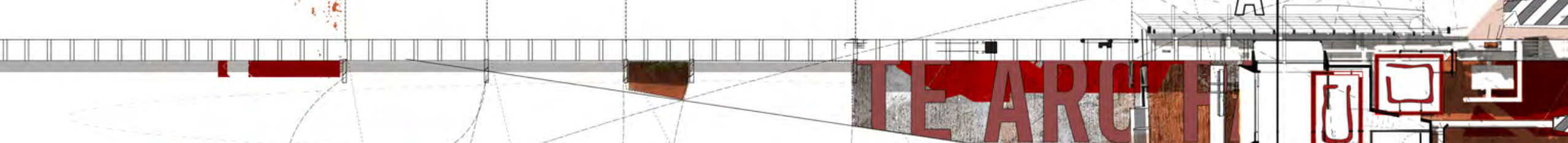

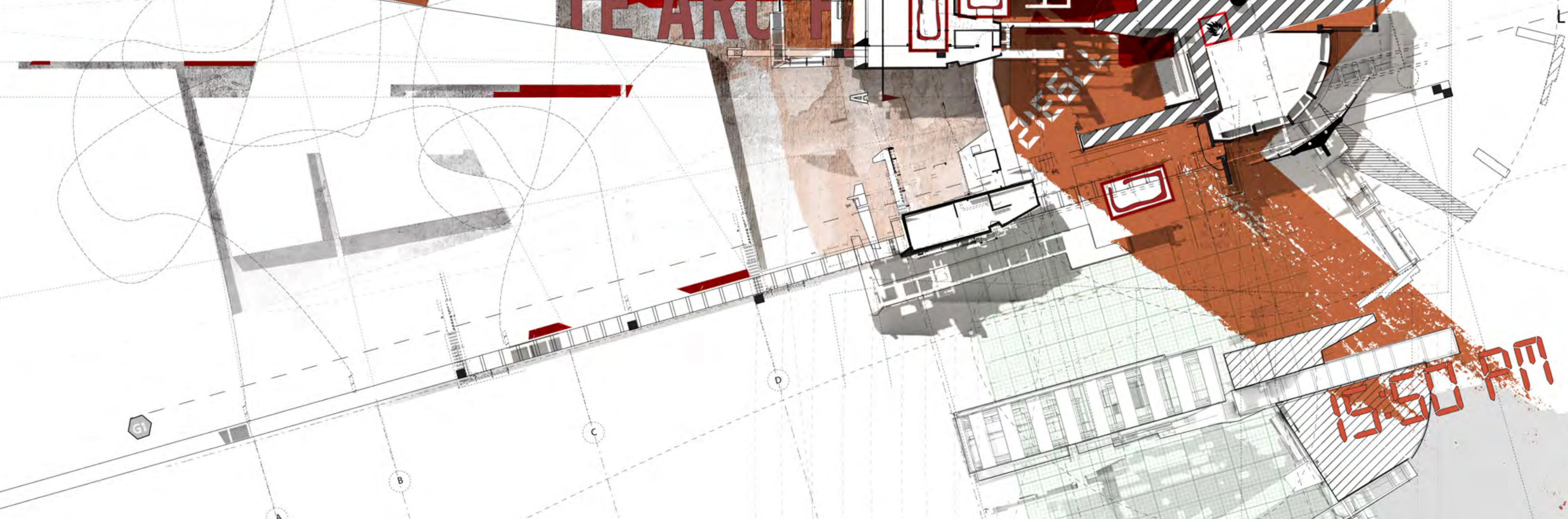





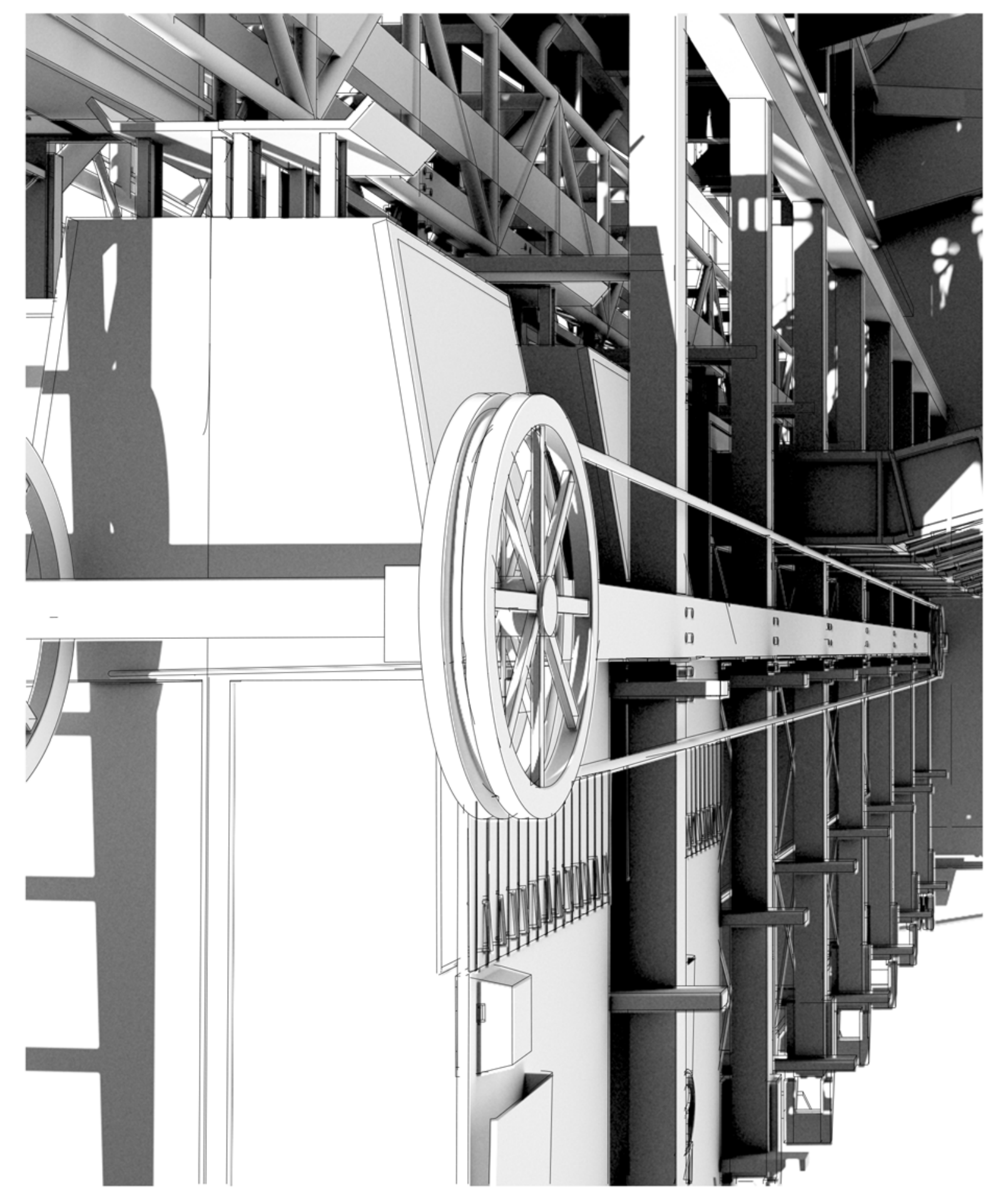

Reasoned argument and clarity are an indispensable part of our quest for knowledge. So are stories and their ambiguities. They are a celebration of the human capacity to find meaning and a recognition that meaning is not something to be discovered but something that humans create. From Adam and Eve [in Milton's Paradise Lost] to Lyra and Will [in Pullman's His Dark Materials], it is that search for meaning hat enchants, excites, moves and inspires,

5.4.3.1 SPATIAL ALLEGORY The final stage of Activation, manifests as the allegorical delivery of the final architectural design outcomes. In this stage, the design begins to transition into a realisable solution for the apartments, where it engages programme, structure and spatial arrangement in response to the allegorical foundation of the design. The pages following describe the entirety of the allegorical project through a combination of text and denotational representation of the architecture. These denotational elements are then arranged and combined into a singular drawing at the end of the chapter, representing the outcome for Culmination, Developed Design - where previous design stages De combined and reflected upon through a sing Taxonometric speculative drawing. This stage of Codex 02 builds on Codex 01, while interrogating new territory for the allegorical project in to an opportunity for its physical delivery. 

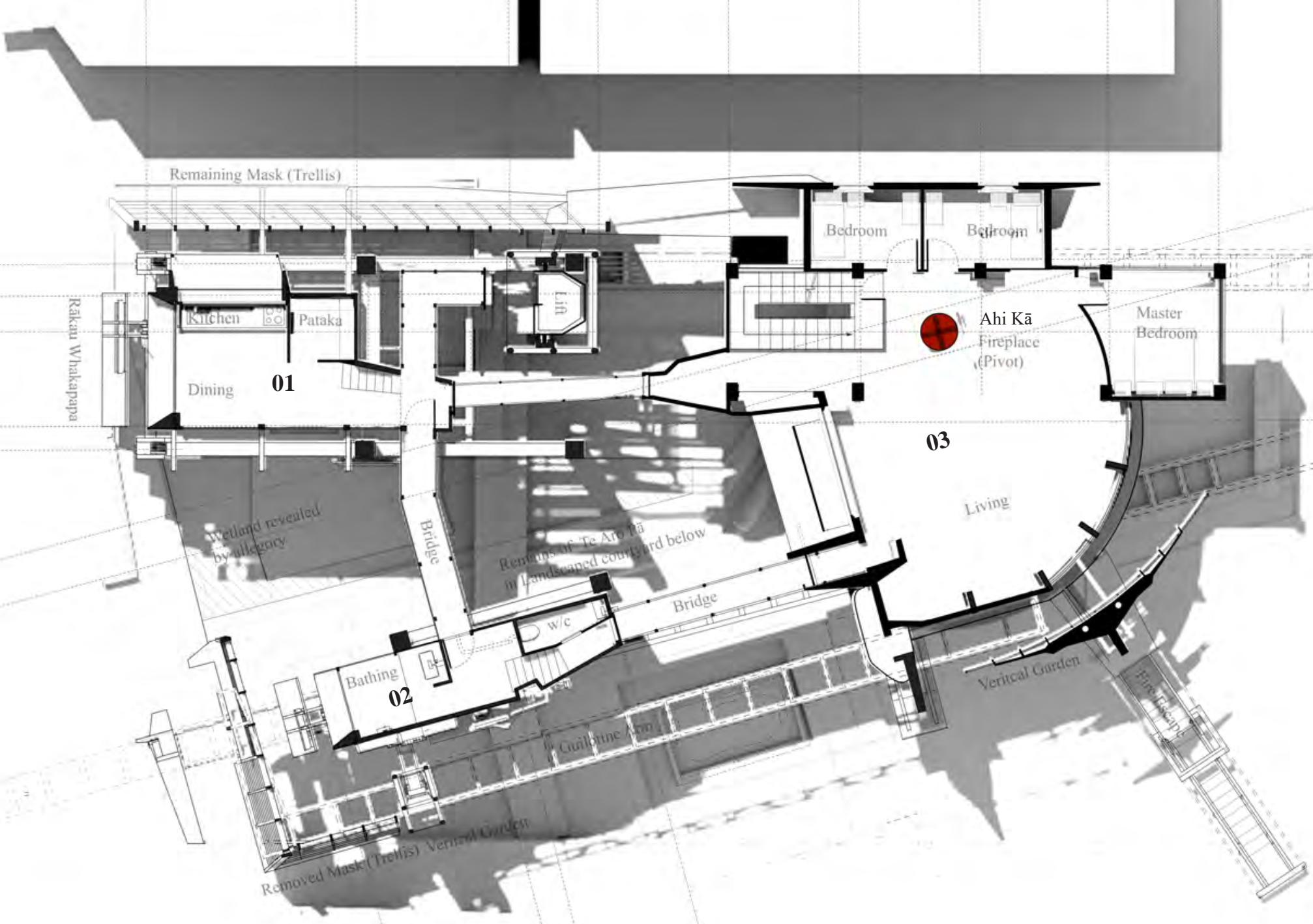

II : $20 \mathrm{PI}$

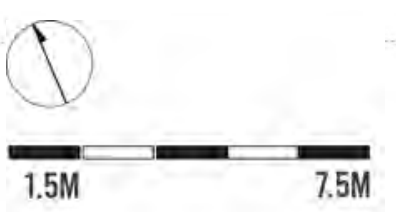

ZONE O2- GUILLOTINE

The lowest level of the Apartment Block, at the bottom of the allegorical rākau whakapapa, contains a community centre for gatherings of rākau whakapapa, contains a preschool and day care $\quad 02$ in the southwest corner represents the building's centre for the youngest generation. Between these allegorical 'mask'. In Pullman's allegory, the dæmon two floors are intergenerational family apartments. (soul) represents who we really are, and the mas level floor of the Apartment Block shows a typical both are visible, we understand our true selves. The 3-bedroom apartment unit. Further allegorical fireplace, the allegorical Ahi Kā, is situated at the devices are translated programmatically through pivot point that enables this to occur. Using the allegorical architectural project as a remnants of the original Te Aro Pā. They represent framework for the design, it is divided into three our cultural heritage from long ago, and they principalzones, eachsymbolising an important daily become the literal foundation for the allegorica ritual. Zone 01, representing the allegorical rākau râkau whakapapa, the mnemonic genealogy whakapapa, contains the spaces for Nourishing. Staff. In this plan, the three zones of the structure Zone 02 , representing the guillotine blade, holds for an enbrace acond these sacred rennants the spaces for Cleansing. Zone 03 , representing the
ZONE 01- RÃKAU WHAKAPAPA

ZONE 03 - NARRATOR Zone 01 in the northwest corner represents the Apartment Building, at the top of the allegorical allegorical râkoun' or 'soul' in the form of an This plan drawing (fig. 5.24) for a typical apartment represents how we show ourselves to others. Whe

the spatial planning of the apartments.

At the ground level of the structure are the sacred

at night. In response to Pullman's Northern Light the literary allegorical generator) and Angus a confrontation.

listen to stories during the day and witness dreams 


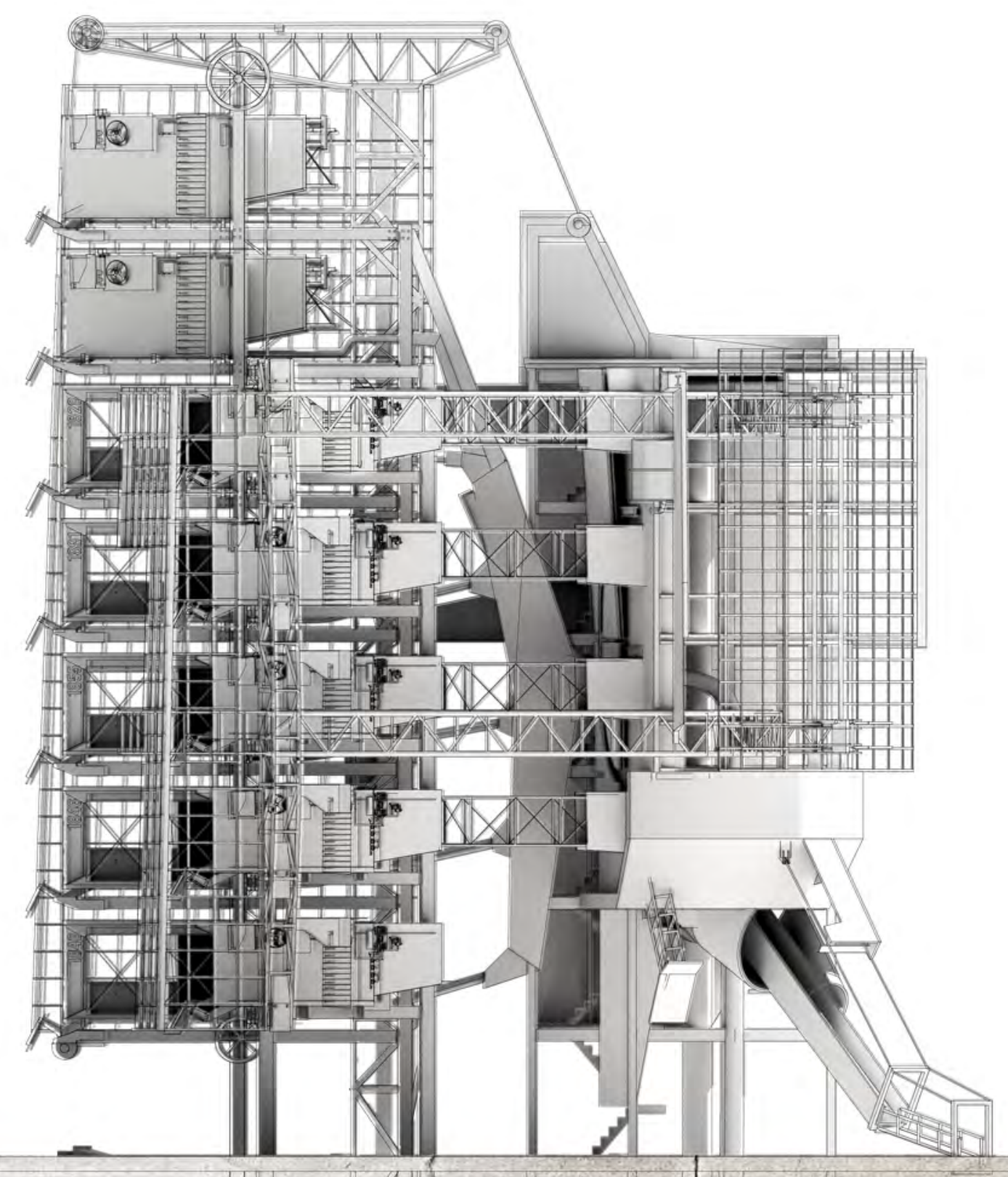

[Place is] a nexus of space and time that remains fluid by the guarantee of human activity... places are transient and impermanent. They exist in chance meetings between strangers: between mechanical and portable units, each wrapped tightly around their inhabitant, included in their obscure rituals, contributing to their personalities and intensifying their troubles.

Opposite | Figure. 5.25, Halley's

Lane Elevation,
Timeline,
Author's drawing

The developed design outcome becomes a vertical allegories. The attribute of Progress (journey) is stack of seven apartment floors that represent a seen in this section drawing for the new Apartment metaphorical interpretation of a rākau whakapapa, a vertical 'mnemonic' device that symbolises time, whakapapa and our connection to the earth. Within the rākau whakapapa are separated zones for the rituals of Nourishing. Cleansing and Gor the separated spaces for cooking, cleansing, and story telling.

This elevation (fig.5.25) shows how the concept of the rākau whakapapa has been used to create a vertical timeline out of the architecture, beginning in the earth, the remnants of the Te Aro Pā, and moving upwards through the present. apartment is separated from the one below like the Angus Fletcher discusses the requirement notches on the rākau whakapapa, each representing for literary allegory to engage both Battle a new family unit of the whakapapa who inhabit (or linty and (conslating litrary alegory into the allegorical growth also rising upwards. Together with the architectural project, Haralmbidou discusses Battle architectural rāka whakapap they becthe as spatiz and Progress as temorat. In this design, the gurdians of our heritage stories, while the the attribute of Battle (confront is is a d in the lan view (Figure 5.24) as the 
These unusual places reveal an architecture that questions logic and eschews precision. that injects a touch of mystery into a discipline hell-bent on explanation-but an architecture that nevertheless remains strangely honest.

In Figure 5.24, the main vertical structure (zone 01) is aligned with the street and represents the rākau whakapapa, while the second structure (zone 02) is meant to appear as if it has been drawn out of the rākau whakapapa to face a different directiongazing toward the original Te Aro Pā. These two structures are in fact one, the left oriented toward the present and the right oriented towards the past.

These are threaded together via a skybridge seen in fig. 5.26, with the exception of the upper level preschool and daycare centres, which remain separated, a representation that the rākau whakapap is ever-growing upward in time. On he right side of the Rāka Whakapap the mask emins intact; over time this becos covered in ivy, a symbol of growth and a natural shade from the sunlight. The ivy loses its leaves in the winter, reflecting the temporal cycle of life, death and rebirth in accordance with the searon

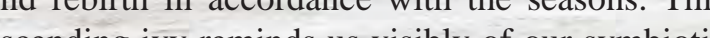
connection to the earth below. 


\section{6}

Architecture exists, like cinema, in the dimension of time and movement. One conceives and reads a building in terms of sequences. To erect a building is to predict and seek effects of contrast and linkage through which one passes.

The rear mechanical structure metaphorically takes on the role of the allegorical narrator, a vessel that symbolises the process of revealing the täkau whakapapa. This narrator reflects Fletcher's rmonic agent, reflecting both the good and bad without bias. It simutan busly takes on the bade w the orator, bestowed with the duty of prot ro he contextuat stores of the land It commicates he sequence of the allegrial actions to the revealing refed through its dyn led for with the prog its for plan communal spaces.

Here apartment occupants gather together into a nited collective whanau. Space here is flexible and can be adapted by the users. In this vessel, an Ilegorical fire can be lit within a vertical 'chimney' hat rises out of the earth and up through every level. The allegorical symbol of fire is taken from Shane Cotton's painting Cross, where it fom fire becomes the pivot point of the architecte the becos the a we apre we are all togeher within one place, our place to. 
Place and memory are integrally connected such that they cannot be understood independently. Place and building are likewise tied, because architecture is always a response to place. The inquiry into the ontology of architecture must therefore include an inquiry into the relation

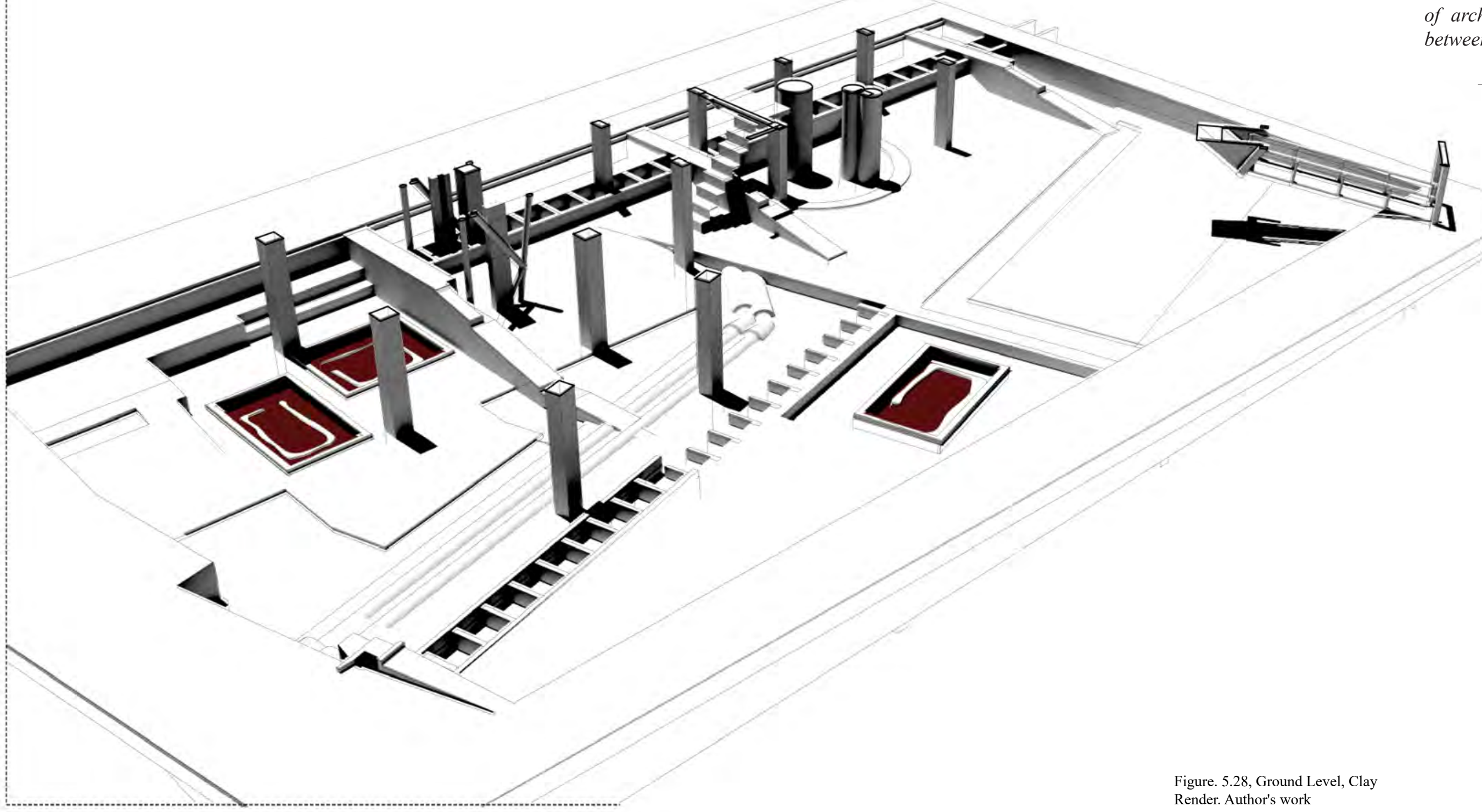

- Jeff Malpas, "Building Memory: Ontology in Architecture," Interstices: Journal of

At the base of the building lie the final remains of Te Aro Pā, situated beneath broad, tempered glass pavers exactly as they are today. But instead of being imprisoned within the ground floor of generic apartment building, the sacred remains of the pā are free to feel the sun. The people are free to rest upon adjacent benches to reflect about time, connection and coming together as one. And most importantly, to remember and to recognise the foul of the heritage stories and rituls the proutions of angawaewae. 


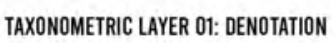
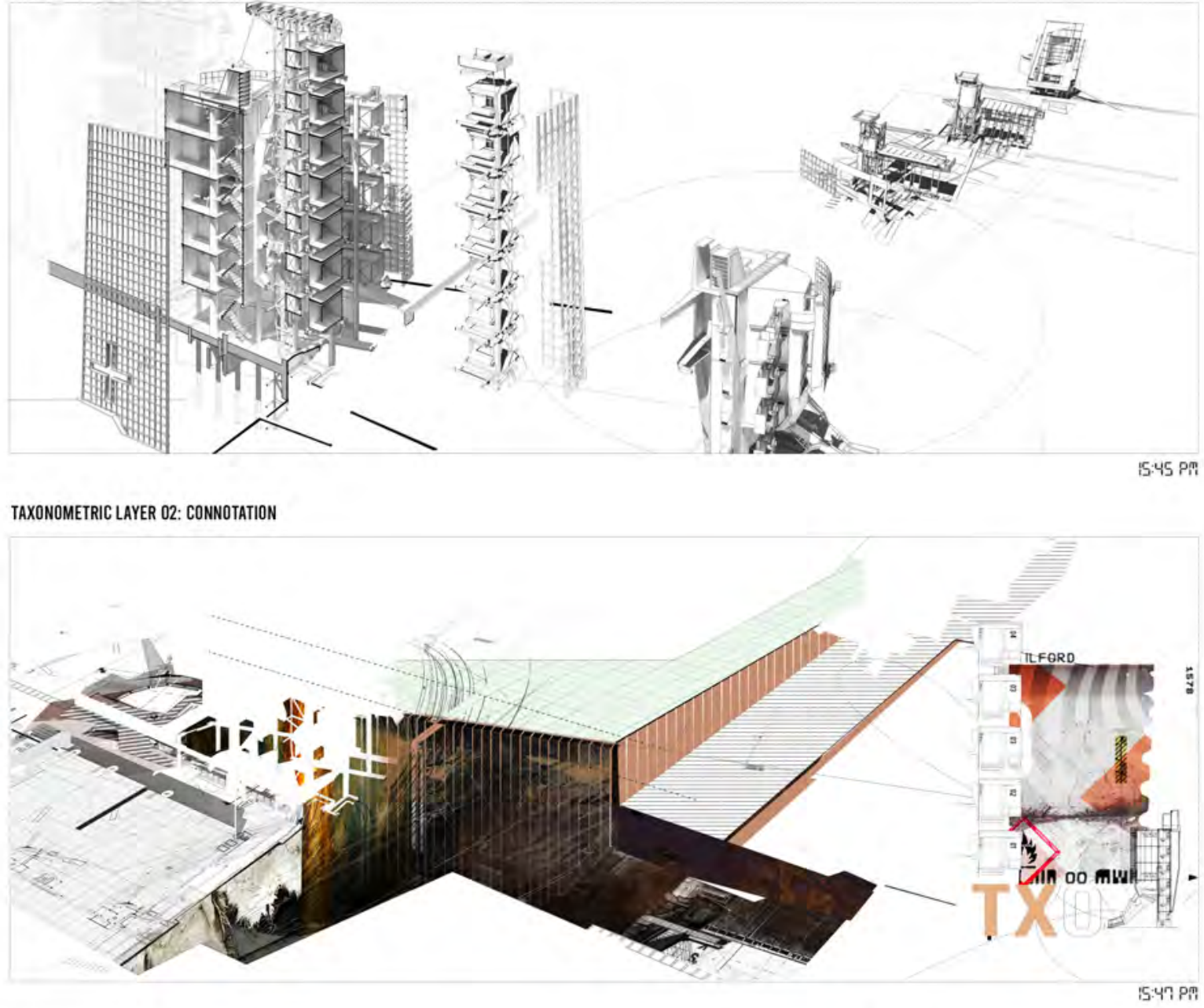

TAXONOMERRIC LAYER 03: ANNOTATION
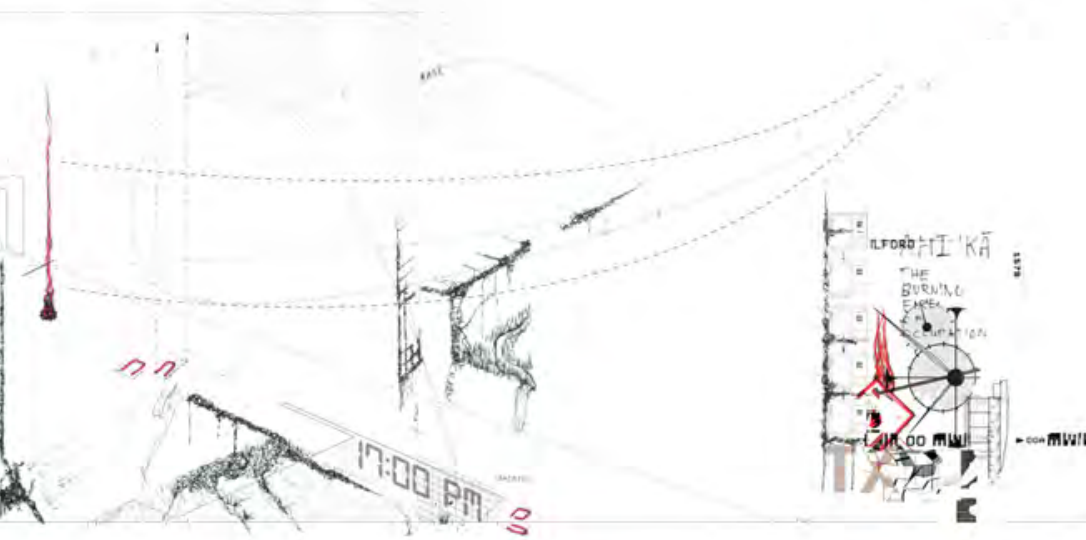

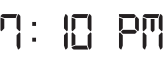

Notations go beyond the visible to engage the invisible aspects of architecture... (phenomenological effect; ... program, event, and social space)... The use of notation marks a shift from demarcated object to extended field.

- Stan Allen, Practice: Architecture, Technique, and Representation, p 33.

5.4.3.2 CUMULATIVE aLLEGORY

Drawing titled Ahi $k \bar{a} \mid$ The Burning Fires of Occupation (overleaf, 5.30), developing upon the Taxonometric Plan (fig.5.21), combines multiple angles within a singular composition. This drawing reiterates the initial horizontal split witnessed in plan, while also introducing the vertical split Rākau Whakapapa at the time of colonisation.

The drawing depicts the temporal nature of this allegorical 'progress', drawing from all five devices from section 3.13: Mirror, Mask, Threshold, Franes and Dance.

The mirror appears through the Denotation layer shown in fig 5.29; in this context, the mirror temporal. The Preliminary Design outcomes are placed in a mirrored dialectic with the Developed Design Apartment, showing the transition of the research from Inception, Design Stage 01 to Culmination, Design Stage 04. This reflects the Cirroring of both Codices, where the final outcome cols to its foundation in Codex 01 .

The mask, also seen in fig 5.29 'Denotational Layer', becomes a fundamental element of the figurative geometry. This mask has been peeled away by the body of the narrator (lower right), revealing the interior of the notched architectura

threshold appears through the Connotation ayer (fig.5.29), becoming the threshold between dark and light. This allegorically represents the realm of Te Pō, revealed by the action of the Silver Guillotine. From this comes Te Ao Mārama, which is represented by the light in which the drawing akes place.

The frame is then embodied in the architectura rākau whakapapa, which acts as a framing device for he layers of contextual heritage that it represents. The frame simultaneously appears through the right-hand key, which provides two-dimension hints relating to the allegorical drawing.

Primarily, this drawing represents the dance, where all designed entities of the thesis are placed within a dance through their composition elationships. This dance is manifested though Annotation layer shown in fig 5.29, where the bep drawing is combinel with the digita he mutilayed allegorich disectic of contex heritage and architectural intervention. 


\subsection{DEVELOPED DESIGN:}

CRITICAL REFLECTION

Design Stage the Guillotine. Together, these devices provide a the experiments from Codex 01 relating to all becoming mute fragments within the Developed three Research Objectives into the design of an Design outcomes, yet clearly evidencing the Apartment Block, which represents $\mathrm{s}$ a multi- marks of its making. Although this drawing is layered answer to the Research Question. The Stage primarily a visual allegory, it establishes visualFour Developed Design outcomes explore how an verbal properties through the numbers, symbols allegorical architectural project can reawaken the and repeated figurative geometries, each of which transformative heritage stories of place identity - is intrinsically related and reflective of the literary enabling architecture as well as its inhabitants to foundation, His Dark Materials, from which it arose. manifest a place to stand $\mid$ Tūrangawaewae.

In Inception, the allegorical provocations were The process of the taxonometric drawing invites translated architecturally through a series of speculative sketch experiments. These experiments largely informed the initial conceptual design of the apartments, providing a rich allegorical narrative of place. In Cognition, the allegorical narrative was then translated into the three-dimensional, where it simultaneously engages allegory and architecture through Cantley's method of the taxonometric drawing - inviting the imagination to remain a participant within the developing design. Activation then building from Cognition, takes the final iterated design and attempts to resolve programmatic function and structure in relation to the allegorical foundation of the project. This is then

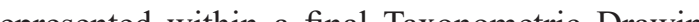
the final outcome of Developed Design.

discrepancies and blurs to begin manifesting within the allegory; this begins to suggest new interpretations that are continuously being derived encouraging a duplicity of meanings. Ultimately once the drawing is completed, it becomes the task of the viewer to add to these interpretations, as they draw their own conclusions from the layered allegory. Finally, the drawing is left at a stage where it is both incomplete and fragmented, preservin he power of allegory through its interpretive nature. This suggests that the drawing is neither fixed nor is the meaning that it represents.

Regarding Fletcher's symbolic actions, a battle is achieved through a plethora of confrontations including the above and below, the light and the dark, the self (narrator) and the soul (rākau whakapan), he private and the commint, the begining and the end, and finally the herite identity and the This final drawing (fig.5.30) establishes Fletcher's the end, five principal traits of allegory within a final contemporary identity. Each confrontation is both allegorical product for the thesis. The drawing interrelated and connected through the figurative evidences a multilayered figurative geometry geometry of the allegory, suggesting a tempora through its primary allegorical devices of the progress in the form of the allegorical dance.

Rākau Whakapapa, the Mask, the Narrator and 


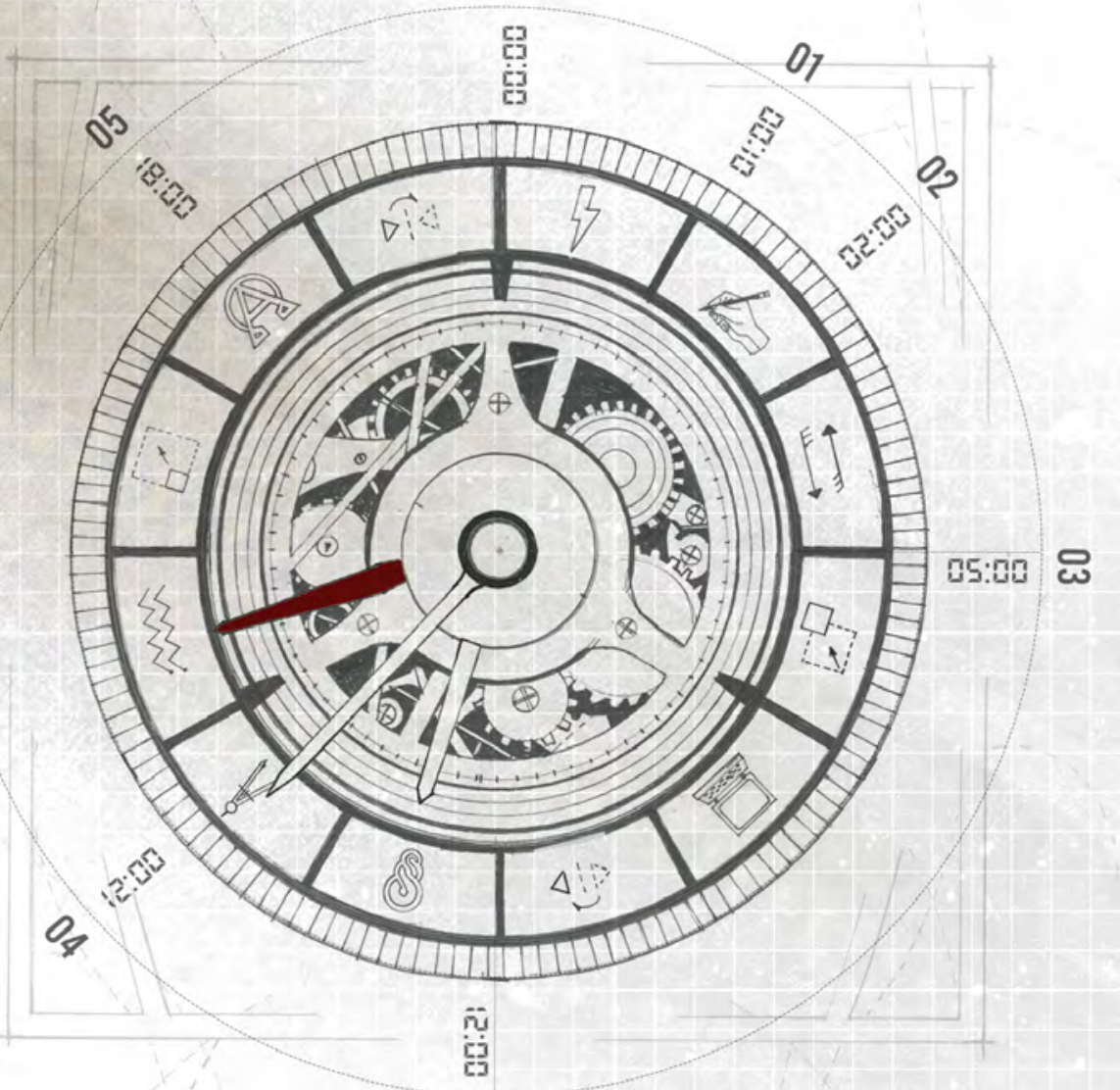

This three-stage method proved reasonably successful in both the design of an allegory and the design of the apartments, arriving at a solutio that reflects the allegorical message holistically through the act of designing, making and planning. Each of the three stages of the Developed Design process resulted in an independent yet intrinsically connected solution to the Research Question, one existing through speculative sketch, one existing through the taxonometric drawing, and the final existing in the three-dimensional realisation of the design.

The design itself represents one possible solution for the apartments, where they are envisioned to bring whakapa together, and help them become even further associated with their cultural heritage hrough architecture. It is possible that if the scope of the research was extended, this programme could be revised and reconsidered allowing for greater number of building occupants.

Due to limitations of time and scope, the research project did not explore the experiential and materia realm of the allegorical architectural outeria instead focusing on the process of designing and engaing allegory through speculative drawing. he research was extended, the next sep would b. est the thre designed outcom of the public toile block, the bus stop and the apartm a singe 


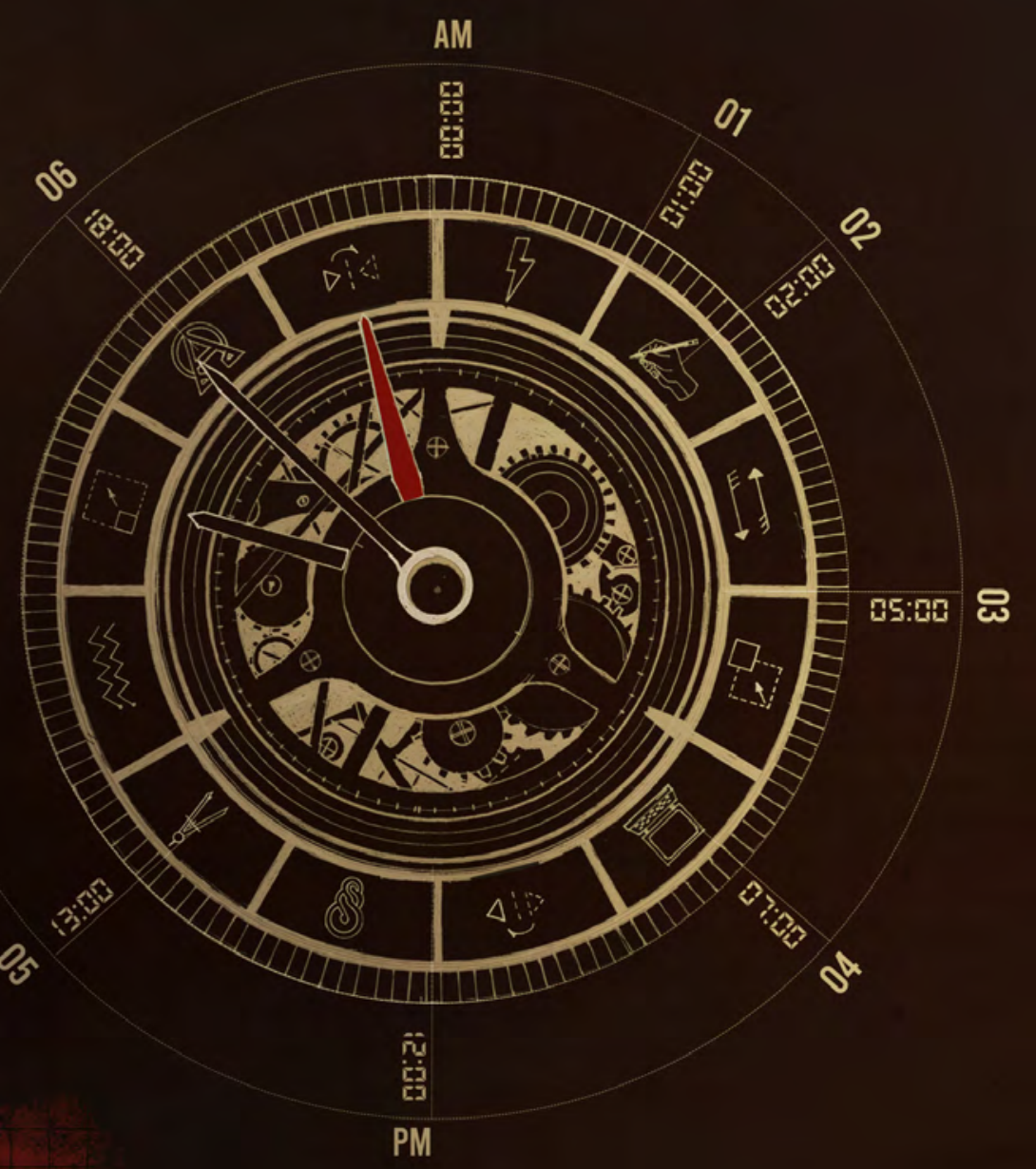

Täne's final demand of the sun so angered Tangotango (The Intensely Dark) that he sent it with a blazing heat to destroy Täne and his companions... Täne solved the problem... separating the sun from the moon and stars, inus creating a cycle of day and night

-Samuel K Parker, “Dialectics of Power in the Māori Creation Myth" p. 17. 
a
(1)

\subsection{CONCLUSION \&}

\section{CRITICAL REFLECTIONS}

In this modern era, urban architecture often tend to disregard contextual heritage, limiting our understanding of place to an acknowledgement of the forces that have shaped its present physical form. Urban architecture sites are typically presented
to the designer as a 'cleared' site-an abstracted to the designer as a 'cleared' site-an abstracted blank canvas, devoid of any concept of place or time relating to its heritage stories. As a result, the foundational and transformative heritage storiesintrinsic to an understanding of place-are lost to
the quickly evolving inner city developments. A the quickly evolving inner city developments. A disconnection is formed, where place is no longer
tied to history, and thus neither are the conceptual ideas that might be developed from it. The city itself becomes the mask above a temporally isolated image - concealing beneath it the transformative truths of its making. For this reason, this has been an important issue to solve through design. This design-led research investigation explored potential approaches for mitigating the loss of transformative
heritage stories within the urban context. It calls for a re-examination of the protocols and methods of traditional architectural design, focusing on the Research Question:

How can urban architecture help to reawaken the transformative heritage stories that form place identity, enabling architecture as well tūrangawaewae?
Why was this Important to Resolve through Design This has been an important issue to resolve through design because the central issue is fundamentally about how our designed environment can help to re-establish our essential connection to place and place making. The thesis addressed the Research Question through the adoption of an allegorical approach to design. Philip Pullman's literary allegory His Dark Materials was used as a provocateur or generator for an allegorical architectural project. In Pullman's trilogy, the "soul' in the form of a 'dæmon' is actively brought to life. This provocation was used to consider how the 'soul' of architecture might be actively brough to life by enabling us to allegorically witness transformative heritage stories that contribute to place identity.

How Successful were the Outcomes

In the context of final outcomes as speculative architectural drawings, this methodology was reasonably successful. If the study were to advance further in future, its application to buildable architecture would need to be further examined. Through an integration and layering of multiple case studies taken from the realms of literature, fine art and architecture, notions of architecture's soul were incrementally nurtured into existence. These notions were then applied allegorically to the croblematic research context of Wellington's innercity suburb Te Aro. They were used to interrogate site and architecture as individual yet interconnected identities arranged within a dialectic confrontation. This 'battle' or 'confrontation' between site and architecture was then translated through the design of three allegorical interventions-a public toilet block, a bus stop, and an apartment buildingand communicated through a series of evolving speculative architectural drawings. 


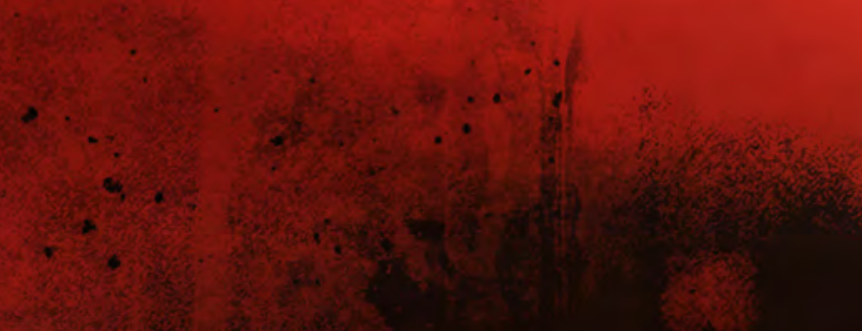

Our ideas are of value to the degree in which we have felt ourselves lost ... The man who discovers a new truth has previously had to smash to atoms almost everyining he had learn, and arises at the new thuth with hands bloodstained from the slaughter of a housand platitudes.

Penelope Haralambidou's proposition that the allegorical architectural project can be used as a critical method draws directly from Angu Fletcher's theories relating to literary allegory. The thesis investigation used the arguments of both theorists to explore how an allegorical architectural project can help to reawaken the transformative heritage stories that form place identity (its 'soul'), enabling architecture as well as its inhabitants to have a place to stand $\mid$ Türangawaewae.

\section{How Successful was the Methodology}

Fletcher's symbolic action of 'battle', as a confrontation of two forces, became fundamental to the development of a dialectic response to place. His second symbolic action 'progress' became intrinsic to the temporal activation and representation of this architectural dialectic. This thesis investigatio used this to help establish a three-part methodology of Inception, Cognition and Activation, where the allegorical architectural project is incrementally transitioned from the imagined to the designed, with each insight building upon the previous, weaving together a richly complex allegoric architectural narrative.

This method proved successful in the formation of site-specific allegorical architecture inviting nonconventional provocations (allegories drawn from literature and fine art) to fuel the imagination as the allegorical argument is developed. It provided the opportunity to address the transformative eritage stories that form place. The preliming design stages began to reawaken these through the seculative design and representation of two small cale architectural interventions. The culminotion of these findings was then developed through the Developed Design of the Taranaki Street apartment complex-forming a three-part response to the Research Question, where each stage of the design, fom Inception to Activation, is presented in Codex 02, Te Ao Mārama, The World of Light.
Conclusions Drawn from the Investigation

By establishing an identity for place derived 列 and architecture, the investigation highlights ef fundamental role of site in the formation of meaningful architectural responses to place. his thinking, site identity must be considered not as a product of architecture, but rather as an enduring narrative that permeates through the layers of the urban fabric - marked and severe by the transformative heritage stories, both good and bad - that have shaped its current physical form. In this respect, the designed outcomes prove successful, each highlighting the issues arising from a loss of heritage stories, including a toilet occupying a sacred pā site, a bus stop located atop redirected stream, and an apartment concealin he rediscovered remains of the once thriving Te

Through the establishment of allegorical 'battle' in the form of a confrontation between site and architecture, these interventions are able to equally prioritise site, becoming a fundamental opportunity for architecture to enhance our awareness of place identity. With the introduction of the temporal, expressed and represented through taxonometric drawing these interventions begin to address the ransformative and temporal nature of our heritage

Constraints and Limitations of the Findings

Although these interventions proved successful in respect to the Research Aim, they ultimately remain constrained to the realm of the conceptual and imaginative, where major developments would still be required to transition them to realizable and buildable outcomes. They also do not address the economic constraints that typically require developer to occupy every square meter of a ste rather than privileging the site's ability to act as the orator of its tales. 
uscovered a marvel as soon as I did... for worlds differ greatly and in this world I saw my daemon for the first time.... People her cannot conceive of worlds where damons are a silent voice in the mind and no more. Can you imagine my astonishment, in turn, at learning that part of my own nature was... beautiful?

Philip Pullman, His Dark Materials, The Subtle Knife, p. 501
This research topic was both highly relevant and personal to me, where a desire to engage my own lost heritage was mirrored by the desire to establish a cultural and contextual place identity (dæmon) through the design of architecture. realised how much can be lost through the lack of acknowledgment of our own cultural heritage stories and saw this issue as largely relevant to architecture also. As a result, this thesis investigation began as an enquiry into the 'soul' of architecture, and manifested into a search for Türangawaewae, highlighting the connection we share with the place to which we belong.

It suggests the need for architecture - as a physical manipulation of place - to acknowledge its own site as a fundamental aspect of its being. It highlights the power of fictional narratives and storytelling to communicate potent ideas and meanings in relation to a holistic understanding of both heritage and place. Finally, it questions the lack of acknowledgement of the heritage landscapes beneath our cities-raising the much bigger issue mankind towards nature.

with the land. It could begin to explore how architecture's dæmon, as the mediator of the built and norlds, might interweave essentia sses of heritage with sustainability through the . biodiversity. It might also begin to explore how co-design could enhance user interaction in the formation of place, encouraging the community become actively involved with protection of

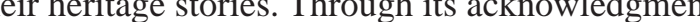

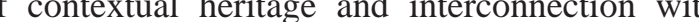
- surrounding ecosystems and community, this

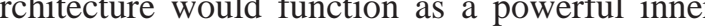
wy symbol, signifying a fundamental shift in how we understand, design and engage place within the

Potential Future Applications of the Finding

Place identity for Māori is embodied in the concept of Tūrangawaewae - a place to stand. For Māori, the place where a person learns important life lessons and feels a connection with their ancestors is usually the marae, where they have earned the right to stand up and make their voices heard, where they are empowered and connected to both the land and to one another. Tūrangawaewaeplace to stand —embodies the fundamental concept

Opportunities for Further Advancement

If the investigation were to be expanded beyond its current scope, the next stage of the investigation would focus on development of the material and experiential properties of the allegorical architecture. This stage is briefly explored in the prologue section, functioning as an additiona enquiry into the material, and suggesting how the allegorical architectural project might ultimately transition from the drawing into a realisable built architecture

Beyond the delivery of buildable architecture, the research might then shift focus towards environmental issues arising from a disconnection of our connection to place

Ultimately the thesis investigation argues that we must return to a point of origin, looking back before moving forward. We must reconnect with the land to move towards a more harmonious blurring of the built and the natural. It is no longer simply duality of one or the other, European or Māori, site or architecture, self or soul; but rather, it is about the dialectic that arises from the confrontation, the blurred realm of mediation, occuring when both entities work through a reasoned means to establish an understanding of contextual truth. from which our heritage has been formed, in orde 


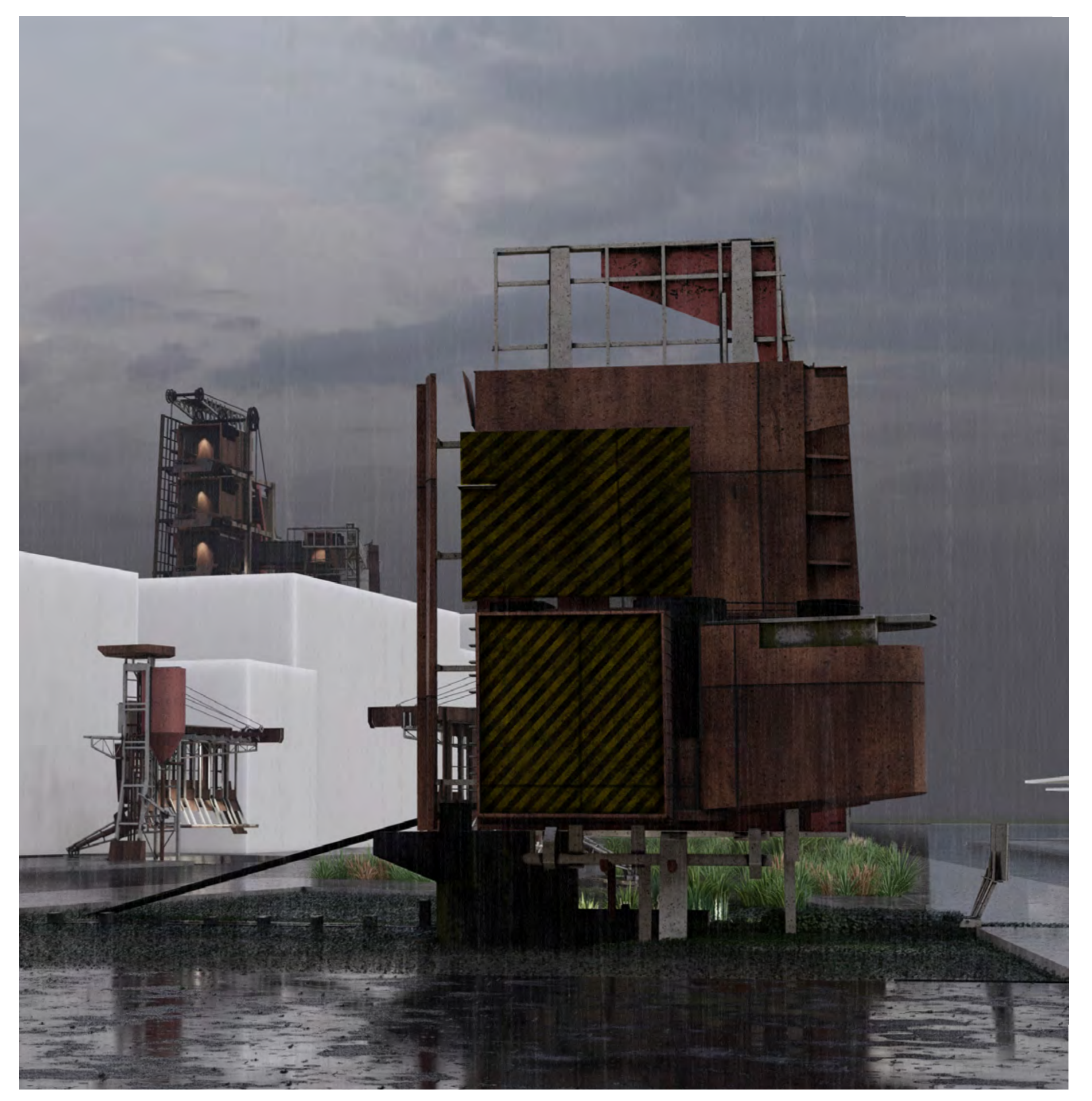

I8: 40 P PI

려 SEPTEMBER EDUHNOX

66

My language is my awakening, my language is the window to my soul.

- Māori proverb

\subsection{EPILOGUE}

EXPERIENTIAL ALLEGORY F o llowing and critical reflections, the three designed outcomes of the bus stop, toilet block and apartment are depicted one final time. This forms an additional design experiment following the conclusion of the thesis, ultimately attempting to cross the threshold between the real and the imagined. This final experiment functions as the segue into furthe research and development, suggesting new ways for evolving the allegorical project even further. The epilogue carries the codex back into the realn of $\mathrm{Te} P \overline{\mathrm{P}}$, with the final render representing the completion of a full cycle from night to day and back to night. 


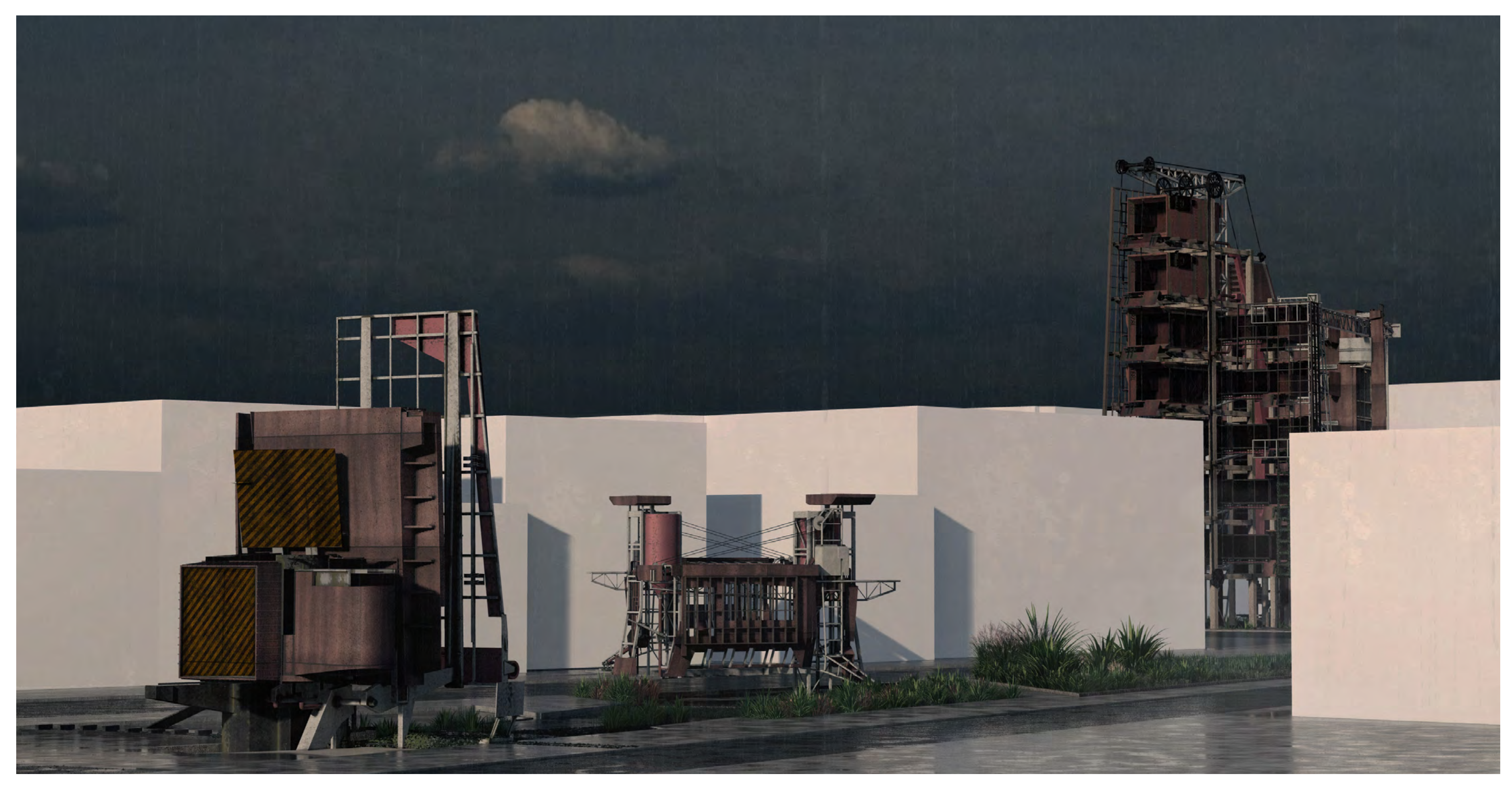




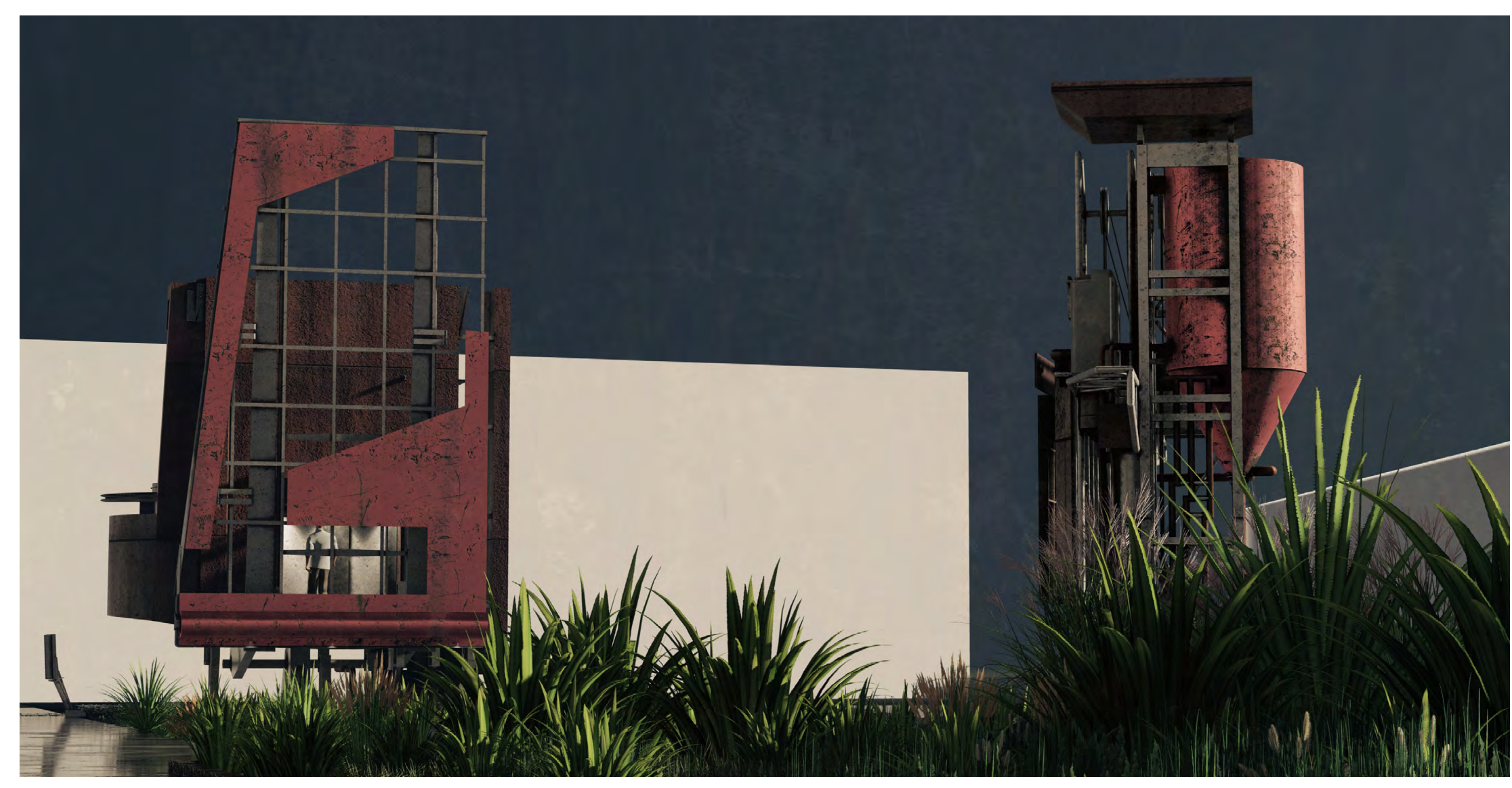




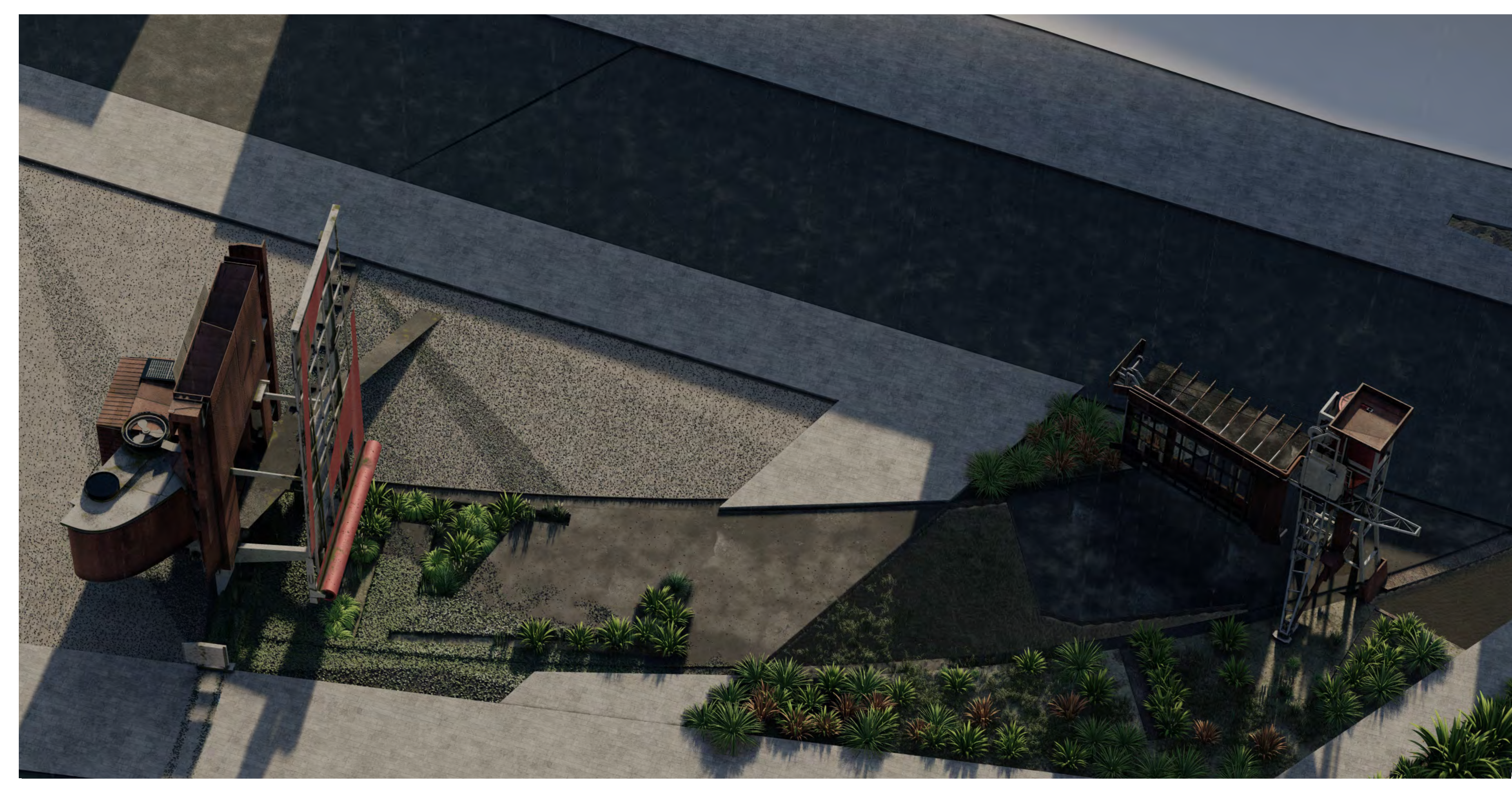




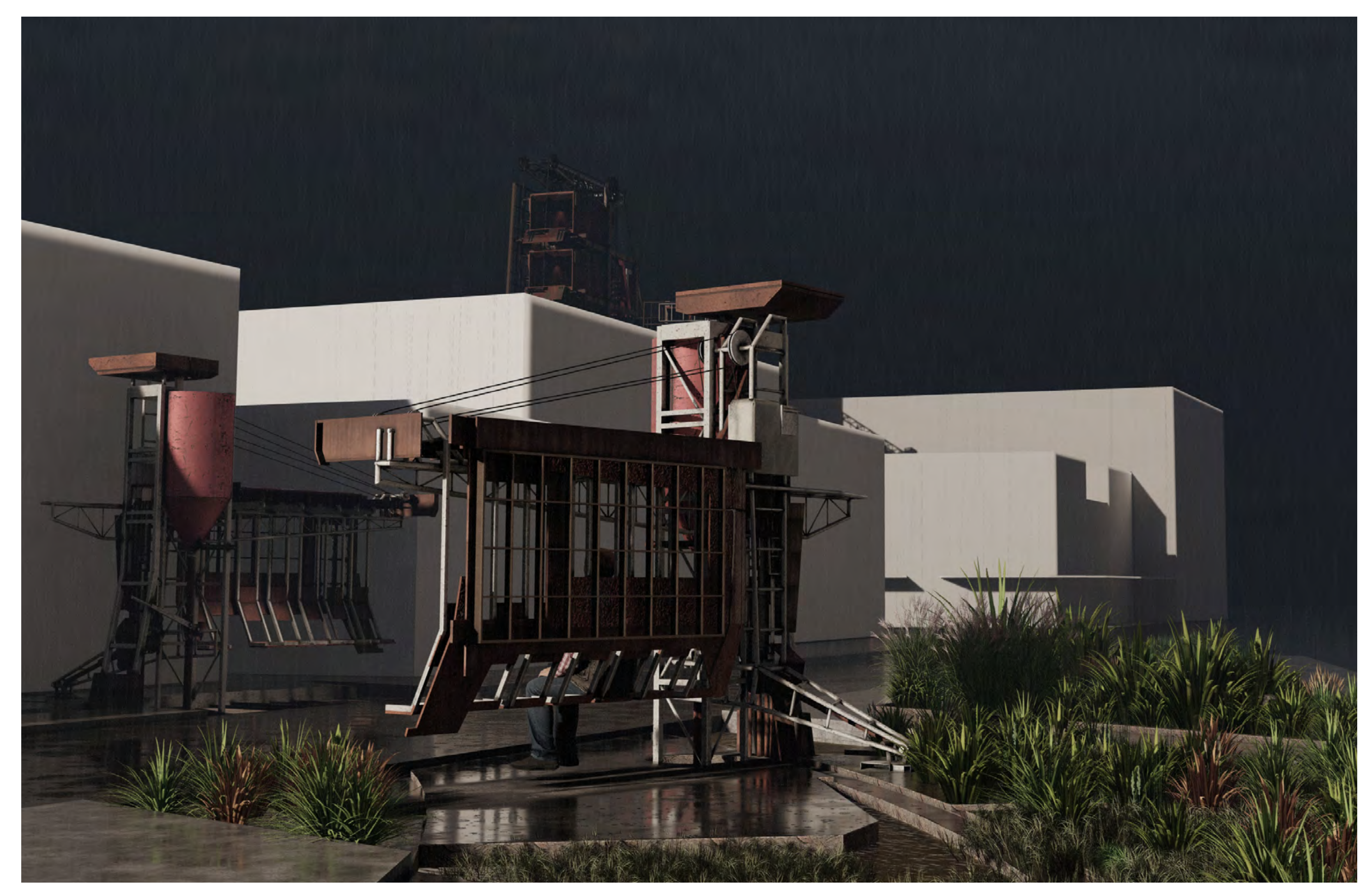



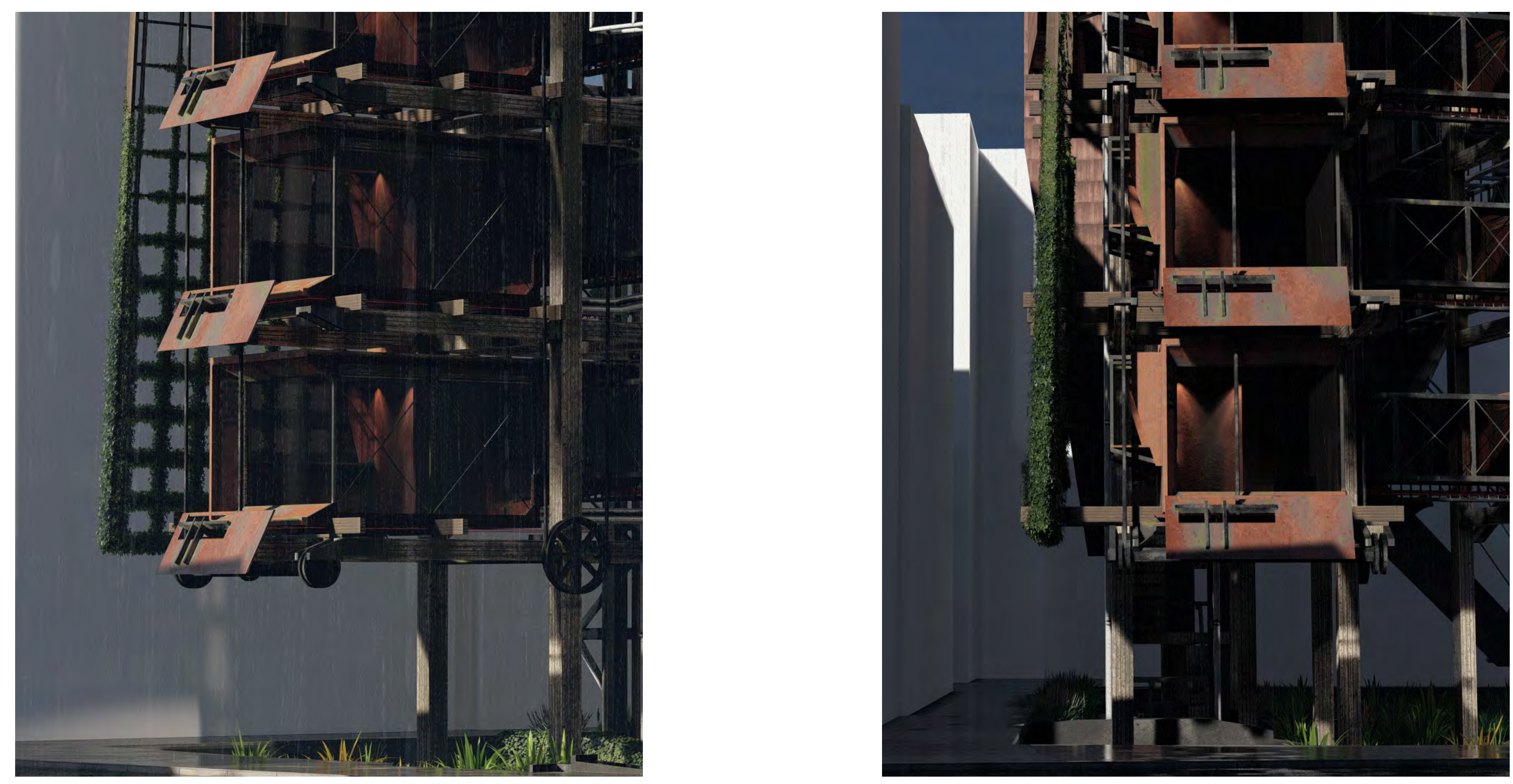

昍: $30 \mathrm{Pm}$ 


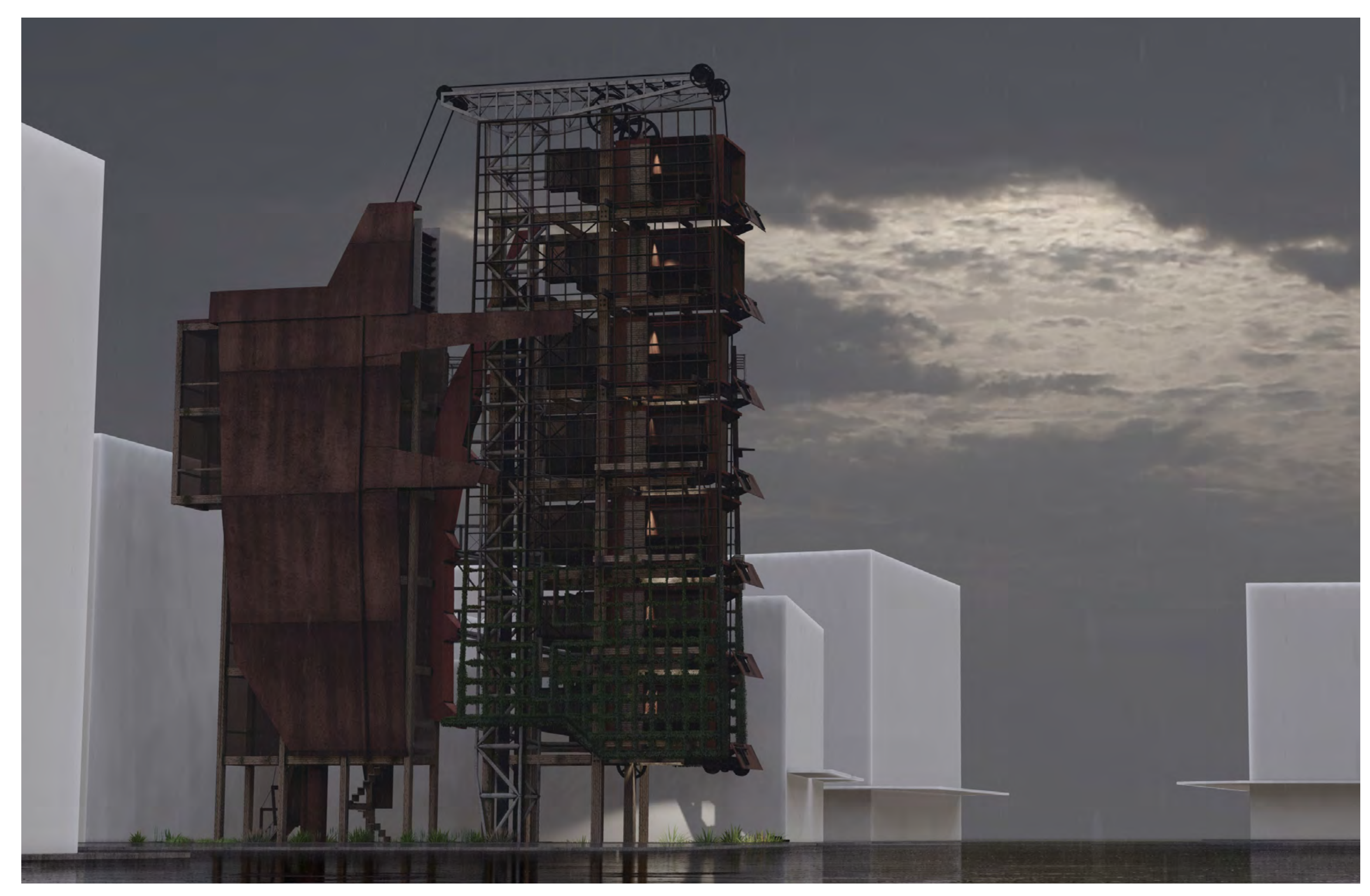

20: $30 \mathrm{Pm}$ 

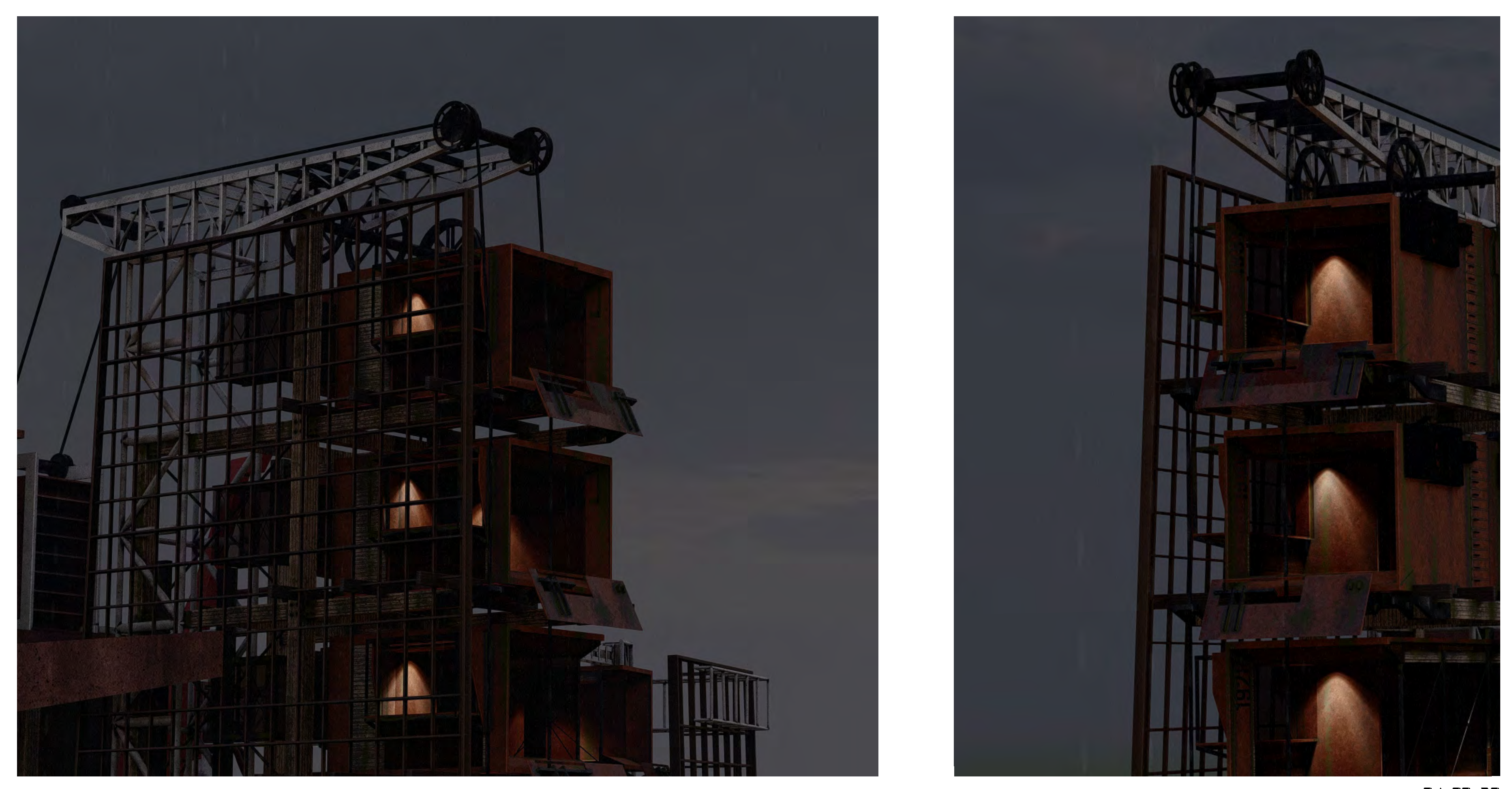


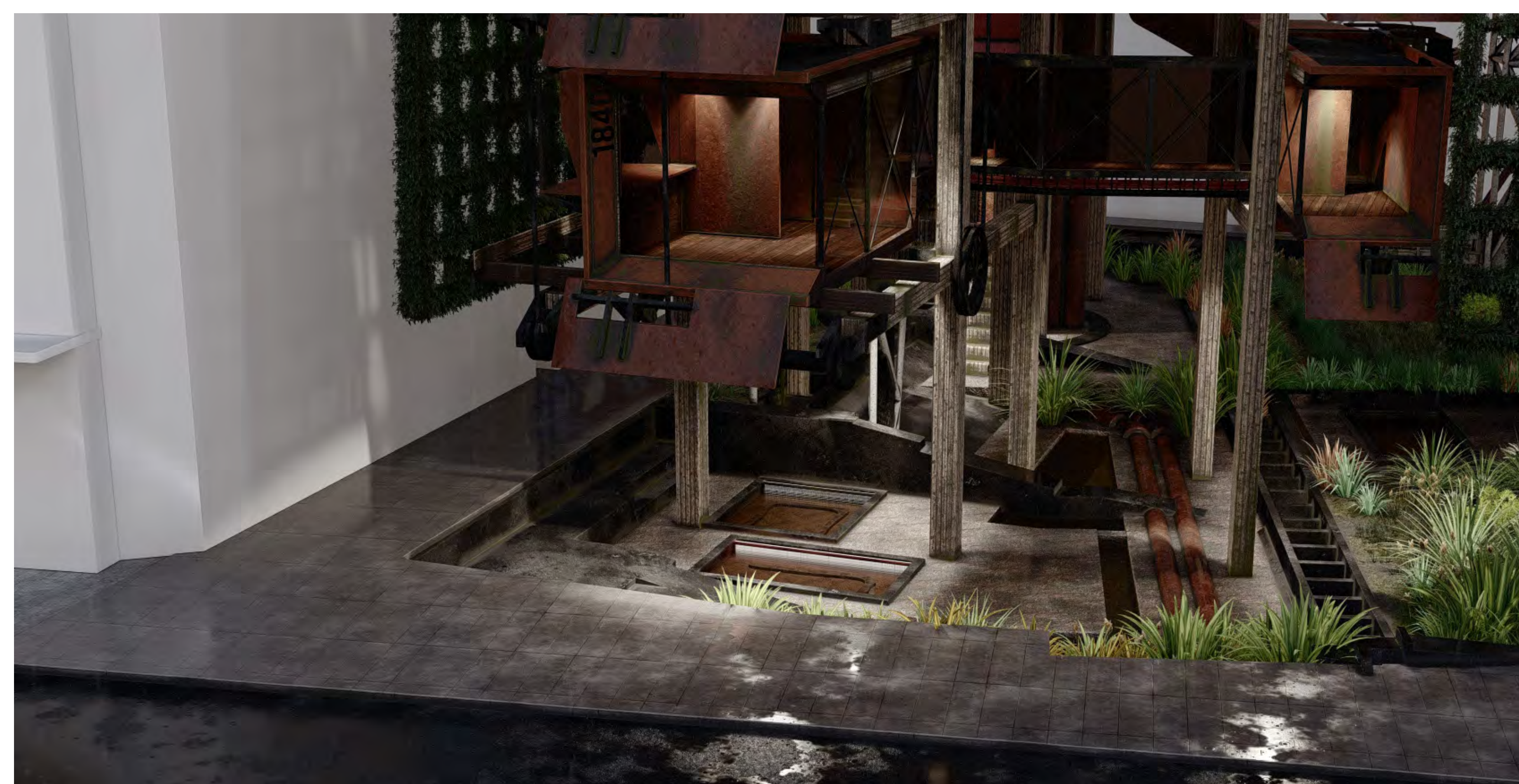




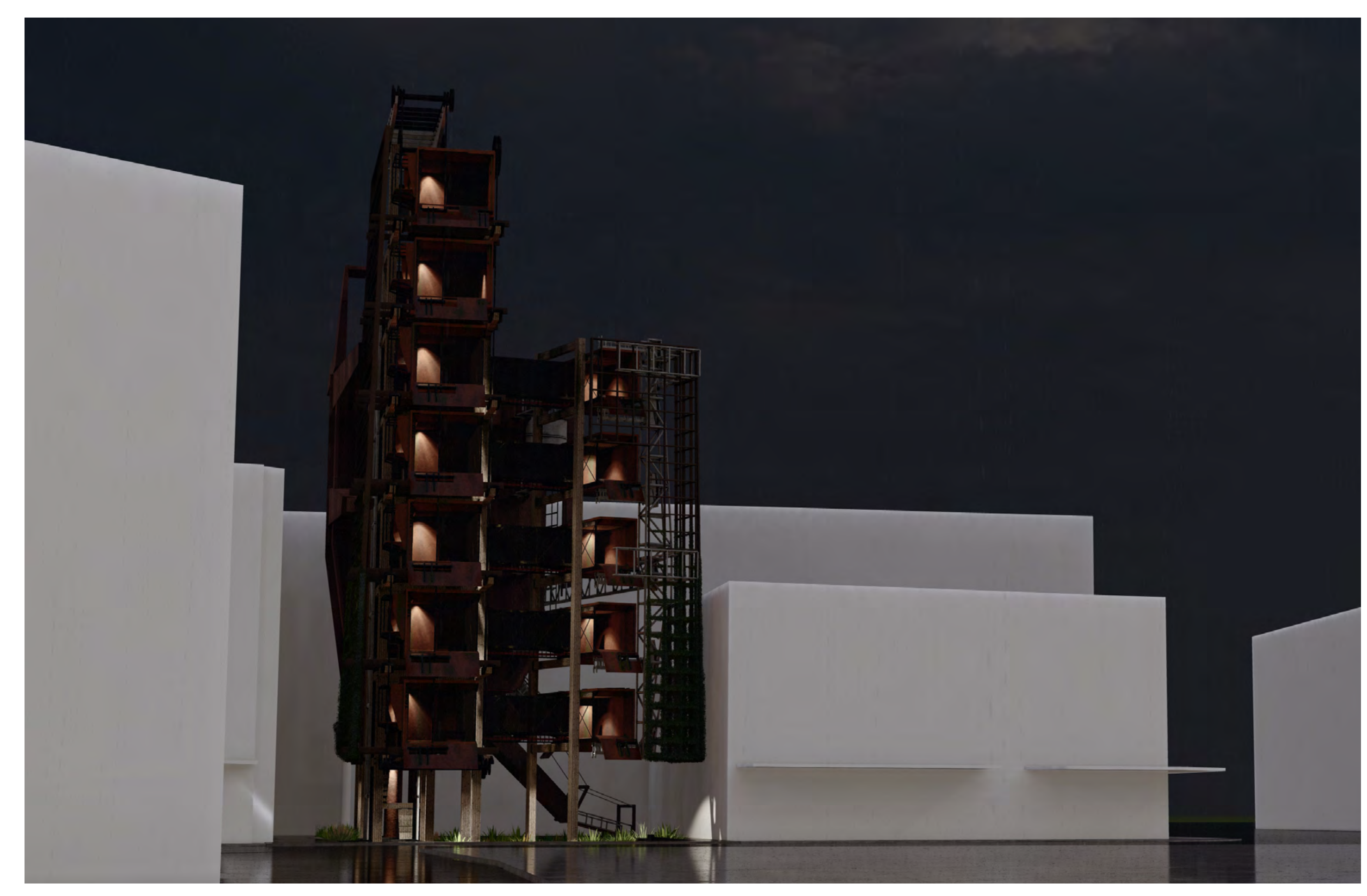




\section{BIBLIOGRAPHY}

Abraham, Raimund. [Un]Built / Raimund Abraham ; with an Introductory Essay by Norbert Miller ; with Contributions by John Hejduk... [et al.] ; Edited by Brigitte Groihofer. Springer, 1996.

Allen, Stan. Practice: Architecture, Technique and Representation - 2nd Edition - S. Routledge, London, 2009, https://www.routledge.com/Practice-Architecture-Technique-and-Representation/Allen/p/ book/9780415776257.

Auckland Art Gallery Toi o Tāmaki, caption beneath Shane Cotton's painting Cross during the Hīkoi to Britomart Exhibition, 12 Dec 2020 - 9 May 2021.

Bernd, Jager. "The Space of Dwelling." Humanitas, vol. XII, no. 03, 1976, p. 327.

Burns, Carol J. “On Site: Architectural Preoccupations." Drawing/Building/Text - Essays in Architectural Theory, Princeton Architectural Press, Inc., 1991, pp. 146-67.

Cantley, Bryan. Mechudzu: New Rhetorics for Architecture / Form:ULA: Bryan Cantley ; [Co-Author, Dora Epstein-Jones.]. Springer, 2011.

--. "Towards a Taxonometric Architecture: D-Con: An." Design Ecologies, vol. 7, 2018, pp. 49-70, doi:10.1386/des.7.48_1.

Crichton, Michael. The Lost World, Pearson Education, 2008.

Clear, Nic. "Drawing Time." Architectural Design, vol. 83, no. 5, 2013, pp. 70-79. Wiley Online Library, doi:https://doi.org/10.1002/ad.1637.

Cornish, Sophie. “'Every Hour of Every Day': The Central Wellington Park That's a Magnet for Violence and Sexual Assault | Stuff.Co.Nz." Stuff.Co.Nz, 2020, https://www.stuff.co.nz/ national/122869163/every-hour-of-every-day-the-central-wellington-park-thats-a-magnet-for-violenceand-sexual-assault-.

--.. "Our Truth, Tā Mātou Pono: Wellington's Te Aro Park, a Small Wedge of Land with a Big History." Stuff, 7 Feb. 2021, https://www.stuff.co.nz/pou-tiaki/our-truth/124016283/our-truth-t-mtou-ponowellingtons-te-aro-park-a-small-wedge-of-land-with-a-big-history

Darden, Douglas. Condemned Building: An Architect's Pre-Text. Princeton Architectural Press, 1993. ---. "Confidences of a Spec-Writer." Oz:, vol. 14, 1992, https://doi.org/10.4148/2378-5853.1238. Deleuze, Gilles and Félix Guattari. Anti-Oedipus: Capitalism and Schizophrenia. Viking Press, 1972. Dieter Schaal, Hans. Paths and Passages; Investigating, Reflections, Planning. Ernst \& Sohn, 1993. Downton, Peter. Design Research. RMIT University Press, 2003, https:/books.google.co.nz/books/ about/Design_Research.html?id=QeTQlylyJTYC\&redir_esc=y.
Edensor, Tim. Industrial Ruins: Space, Aesthetics and Materiality. Berg Publishers, 2005.

Eisenstein, Sergei M. "Montage and Architecture." Assemblage, no. 10, The MIT Press, 1989, pp. 1111. JSTOR, doi:10.2307/3171145.

Fiorenzoli, Giuliano. "Exhibition of Architectural Drawings", Giulianofiorenzoli.com

Fletcher, Angus. Allegory: The Theory of a Symbolic Mode. Cornell University Press, 1964.

Fletcher, Angus J. S. "Allegory Without Ideas." Thinking Allegory Otherwise, Stanford University Press, 2009. stanford universitypressscholarship com, https://stanford universitypressscholarship.con/ view/10.11126/stanford/9780804763806.001.0001/upso-9780804763806-chapter-2.

Focualt, Michel. "Des Espaces Autres" (Of Other Spaces: Utopias and Heterotopias) | Post. https://post. at.moma.org/sources/17/publications/210. Accessed 6 Mar. 2020.

"Four-year Sentence for Church Arson", 2009, URL: https://www.stuff.co.nz/national/crime/632098 Four-year-sentence-for-church-arsonsearch?idiom $=\&$ phrase $=\&$ proverb $=\&$ loan $=\&$ histLoanWords $=\&$ ke words $=\mathrm{m} \% \mathrm{C} 4 \% 81$ tauranga $+\mathrm{M} \% \mathrm{C} 4 \% 81$ ori

Forster, Kurt. “[Essay by Kurt Forster].” Design Quarterly, no. 122, Walker Art Center, 1983, pp. 27-27. JSTOR, doi:10.2307/4091081.

Freitas, Donna, and Jason E. King. Killing the Imposter God: Philip Pullman's Spiritual Imagination in His Dark Materials. John Wiley \& Sons, 2007.

Frost, Lady with Ermine https://pullmanhdm.com/2019/10/05/lyra-and-her-daemon/

Greenwell, Amanda M. “'The Language of Pictures': Visual Reresentation and Spectatorship in Philip Pullman's 'His Dark Materials."” Studies in the Novel, vol. 42, no. 1/2, Johns Hopkins University Press, 2010, pp. 99-120.

Hamel, Catherine. "Drawing Lines of Confrontation." Models to Drawings: Imagination and Representation in Architecture, Routledge, pp. 201, 203.

Haralambidou, Penelope. "The Allegorical Project: Architecture as Figurative Theory.” Black Dog Publishing no. Architecture and Authorship, 2007. www academia edu, https://www. academia. edu/1189899/The allegorical project architecture as figurative theory

--.. "The Fall: The Allegorical Architectural Project as a Critical Method." Critical Architecture, Routledge, Sept. 2007, pp. 245-56. www.taylorfrancis.com, doi:10.4324/9780203945667-36.

Hill, Jonathan. Occupying Architecture: Between the Architect and the User. Taylor and Francis, 2005. ewaharoa victoria ac nz, doi:10.4324/9780203983829.

Hogue, Martin. "The Site as Project: Lessons from Land Art and Conceptual Art." Journal of Architectural Education (1984-), vol. 57, no. 3, [Taylor \& Francis, Ltd., Association of Collegiate Schools of Architecture, Inc, 2004, pp. 54-61. 
Holl, Steven, et al. Questions of Perception: Phenomenology of Architecture. 2nd edition, William K Stout Pub, 2007.

IMBD. “Philip Pullman - Biography.” Imbd.Com, https://www.imdb.com/name/nm1099514/bio. Accessed 13 Apr. 2021.

Jarmusch, Jim. “Things I've Learned: Jim Jarmusch.” Moviemaker.Com, 2013, https://www. moviemaker.com/jim-jarmusch-5-golden-rules-of-moviemaking/.

Jung, Carl. The Relationships between the Ego and the Unconscious. 1928, https://www.barnesandnoble. com/w/collected-works-of-cg-jung-volume-7-c-g-jung/1110894797.

Kerr, Pete. "Downtown Discovery." Heritage New Zealand, no. 108, New Zealand Historic Places Trust, Feb. 2008, pp. 4-9.

Lander, Maureen. "Te Pō: The Perpetual Night.” Auckland Art Gallery, 2004, https://www. aucklandartgallery.com/page/te-po.

Last, John M., editor. "A Dictionary of Public Health." A Dictionary of Public Health, Oxford University Press, 2007. www.oxfordreference.com, https://www.oxfordreference.com/view/10.1093 acref/9780195160901.001.0001/acref-9780195160901?avail_01=free\&avail_02=unlocked\&btog=ch ap\&hide=true\&skipEditions $=$ true\&source $=\% 2 \mathrm{~F} 10.1093 \% 2 \mathrm{Facref} \% 2 \mathrm{~F} 9780195160901.001 .0001 \% 2 \mathrm{~F}$ acref-9780195160901\&type_0=bilingualdictionaries\&type_1=book\&type_2=englishdictionaries\&type $3=$ overviewpages\&type_4=quotations\&type_5=subjectreference\&type_6=-timelines

Lee, Christina, editor. Violating Time: History, Memory, and Nostalgia in Cinema. Continuun International Publishing Group, 2008. DOI.org (Crossref), doi:10.5040/9781628929164.

Leonard, Robert. Cliff Whiting: Te Po, Te Whaiao, Te Ao Marama (From out of the Darkness, the World of Being, to the World of Light). 2021, https://robertleonard.org/cliff-whiting-te-po-te-whaiao-te-aomarama-from-out-of-the-darkness-the-world-of-being-to-the-world-of-light/.

Lightman, Alan P. Einstein's Dreams. Sceptre, 1994.

MacQueen, John. Allegory. Methuen, 1970.

Malik, Kenan. "From Milton to Pullman, the Quest for Truth Is Riddled with Ambiguity." The Guardian 29 Dec. 2019, http://www.theguardian.com/commentisfree/2019/dec/29/from-milton-to-pullman-thequest-for-truth-is-riddled-with-ambiguity.

Malpas, jeff. "Building Memory: Ontology in Architecture." Interstices:Journal of Architecture and Related Arts, vol. 13, 2012, pp. 11-21.

McGregor, James. "The Architect as Storyteller: Making Places in John Hedjuk's Masques."

Architectural Theory Review, vol. 7, no. 2, Routledge, Nov. 2002, pp. 59-70. Taylor and Francis+NEJM, doi:10.1080/13264820209478457.
Menzies, Erin. "Progress Vs. Preservation, A History of Te Aro, Wellington". https://www.nzta.govt.nz/ assets/projects/wicb/resources/pdf/Te-Aro-History.pdf

Mikaere, Ani. “Colonising Myths - Maori Realities: He Rukuruku Whakaaro”. Huia (NZ) Ltd, 2013. ProQuest Ebook Central, http://ebookcentral.proquest.com/lib/vuw/detail.action?docID=1359729.

Milton, John. "Paradise Lost." Poetry Foundation, 1667, https://www.poetryfoundation.org/ poems/45718/paradise-lost-book-1-1674-version.

Munch, Anders V. "Architecture as Multimedia. Jean Nouvel, the DR Concert Hall, and the Gesamtkunstwerk." The Nordic Journal of Aesthetics, vol. 20, no. 36-37, 36-37, 2009. tidsskrift.dk, doi:10.7146/nja.v20i36-37.2798

Newell, Jenny, Pacific Art in Detail, Harvard University Press; 2011 (pp. 64-65).

Nicholson, Ben. Appliance House. Chicago Institute for Architecture and Urbanism, 1990.

Parker, Samuel K. "Dialectics of Power in the Maori Creation Myth." Pacific Studies, vol. 10, no. 3, Brigham Young University, Hawaii Campus, July 1987, pp. 1-26.

Pullman, Philip. His Dark Materials. Book 1, The Golden Compass / Philip Pullman. Laurel Leaf Books, 2007.

--.. "Philip Pullman's Introduction to Paradise Lost." British Library, 2005, https://www.bl.uk/ restoration-18th-century-literature/articles/philip-pullmans-introduction-to-paradise-lost.

Robinson, Karen D. “His Dark Materials: A Look into Pullman’s Interpretation of Milton's Paradise Lost." Mythopoeic Society, vol. 24, no. 2, 2004.

Saurat, Denis. "Blake and Milton". Nabu Press, 1923.

Spiller, Neil. "Baroness's Filaments.” Neilspiller.Com, 2008, http://www.neilspiller.com/projects/ communicating-vessels/baroness-filaments.

---. Drawing Architecture / Guest-Edited by Neil Spiller. John Wiley \& Sons, 2013.

--. "Future Fantasticals." Drawing Futures, edited by Laura Allen and Luke Caspar Pearson, UCL Press, 2016, pp. 139-204. JSTOR, doi:10.2307/j.ctt1ht4ws4.7.

--. Lost Architectures. Wiley, 2001.

---. "Telling Stories." Architectural Design, vol. 80, no. 1, John Wiley \& Sons, Ltd, 2010, pp. 128-29. tewaharoa.victoria.ac.nz, doi:10.1002/ad.1023.

--.. "In Praise of The Blur". Architectural Design, vol. 78, no 2, John Wiley \& Sons, Ltd, 2008. Stuart Keriata and Mellish, Liz. "Tūrangawaewae, Time and Meaning: Two urban Māori icons" Proceedings of the 13th Australasian Urban History Planning History Conference 2016, 29 Jun 2018. p. $455-467$. 
"Staff ('rakau Whakapapa') | British Museum." The British Museum, https://www.britishmuseum.org/ collection/object/E_Oc1854-1229-22. Accessed 4 May 2021.

Taonga, New Zealand Ministry for Culture and Heritage Te Manatu. Whakapapa - Genealogy. Ministry or Culture and Heritage Te Manatu Taonga, https://teara govt.nz/en/whakapapa-genealogy. Accessed 4 May 2021

Te Ahukaramū Charles, Royal " Māori Creation Traditions - Common Threads in Creation Stories." Ministry for Culture and Heritage Te Manatu Taonga, https://teara.govt.nz/en/photograph/2422/thekoru. Accessed 13 Apr. 2021.

"The History of Te Aro Park." Spatialtypographyamynewman, 2015, https://

spatialtypographyamynewman.wordpress.com/2015/04/14/the-history-of-te-aro-park/.

Tom. "WellUrban: Nightmare on Taranaki St." Personal Reflections on Urbanism, Urban Life and Sustainable Urban Design in Wellington, New Zealand., httpp//wellurban.blogspot.com/2007/01/ .

Tucker, Nicholas. Darkness Visible: Inside the World of Philip Pullman. Wizard, 2003.

Venable, Shannon L. Gold: A Cultural Encyclopedia. ABC-CLIO, LLC, 2011. ProQuest Ebook Central, http://ebookcentral.proquest.com/lib/vuw/detail.action?docID=678293.

Ware, Felicity, et al. "Kaupapa Kōrero: A Māori Cultural Approach to Narrative Inquiry.” AlterNative: An International Journal of Indigenous Peoples, vol. 14, no. 1, SAGE Publications Ltd, Mar. 2018, pp. $77 / 1177180117744810$

White, Anne. "Mircea Eliade's 'The Sacred and the Profane': Identifying and Solving the Human

Problem of Environmental Decline." International Journal of the Humanities, vol. 8, no 4, Common Ground Research Networks, July 2010, p. 107-16. EBSCOhost, doi:10.18848/1447-9508/CGP/ v08i04/42901.

Young, Liam. "Brave New Now". Architectural Design, 2013-05, Vol.83 (3), p. 74-81). https://dol. org/10.1002/ad.1593. 


\section{SOURCES OF FIGURES}

All figures not listed are Author's ow

Figure 2.01 Penelope Haralambidou, The Fall, model, 2004, in “The Fall: The Allegorical Architectural Project as a Critical Method." Critical Architecture, 2007, p. 245-56. Print.

Figure 2.02 Penelope Haralambidou, The Fall, sketchbook, 1998 in "The Fall: The Allegorical Architectural Project as a Critical Method." Critical Architecture, 2007, p. 245-56. Print.

Figure 2.03 Alethiometers being assembled on set HBO His Dark Materials Filmic Reproduction His Dark Materials, HBO, 2019

https//w w hesunco

Figure 2.04 Leonardo da Vinci, Lady with an Ermine, 1840-90

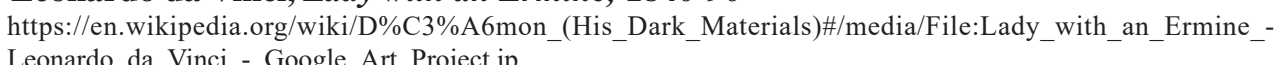

Figure 2.05 Shane Cotton, Kenesis: Kotahi Ki Kotahi, 1999 collection of Daniel K Brown and Mark K Johnson

Figure 2.06 Neil Spiller, Baroness's Filaments, 2008 http://www.neilspiller.com/projects/communicating-vessels/baroness-filaments

Figure 2.08 Zacharie Gaudrillot-Roy, Facades, Ongoing is

Figure 2.08a Dan Slavinsky, 'Possibilities of a Threshold', Drawings From the End of Time. 2010. hitp:///ucydunnarchi.blogspot.com/2013/07/dan-slavinsky-architect.hth

Figure 2.11 A.L.Moure Strangis, Planta industrial, 2016.

https://almstrangis.tumblr.com/post/150139195956/planta-i

Figure 2.11a Kirill Chelushkin, Untitled Works, 1995-1997

Figure 2.14 Ralph Hotere, Lo negro sobre lo oro, 1992

http://www.artnet.com/artiststralph-hotere/lo-negro-sobre-lo-oro-cmPk-tJ3ldzcnE1 pBrm15A2

Figure 3.01 Yves Tanguy, Reply to Red, 1943.

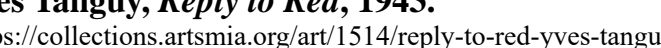

Figure 3.02 Bryan Cantley, Enantiomorphistic Inversions, in Mechudzu: New Rhetorics for Architecture / Form:ULA. 2011. Print. p. 28-29

Figure 3.03 Max Ernst, Attirement of the Bride, 1949$$
\text { https://www.guggenheim-venice.it/en/art/works/attirement-of-the-bride }
$$

Figure 3.04 Douglas Darden, Hostel, 1993

https://portal.cca.edu/events-calendar/condemned-buildings-and-other-stories-drawings-douglas-darden/

Figure 3.05 Georgio de Chirico, The Soothsayer's Recompense, 1913. hittp://www.britannica.com/topic/The-Soothsayers-Recompense
Figure 3.06 Hans Dieter Schaal, Entrance Situations in a Row, in Paths and Passsages, 1973. Print. p. 123

Figure 3.07 Kay Sage, The Fourteen Daggers, 1942

https://www.artsy.net/artistkay-sage

Figure 3.08 John Hejduk, Wall House 01, 1968-1974

https://www.cca.qc.ca/en/archise 01, 1968-1974.

Figure 3.09 Salvador Dali, The Poetry of America, 1943 https://www.dalipaintings.com/the-poetry-of-america.jp

Figure 3.10 Morphosis, Higashi Azabu Building, 1989-1991. ths:/www morphosis com/architecture/79/

Figure 3.14 'Overlooking Te Aro, Wellington', c. 1860, Photograph. Photographer unidentified. https://i.pinimg.com/236x/43/37/30/4337306774136878ccaf4440995b5982--maori-kiwi.jpg

Figure 3.15 George Richard Hilliard, b 1801: Te Aro Pā, 1841

https://www.wcl.govt.nz/maori/wellington/tearopa.html

Figure 3.16

Edmund Norman, Attributed works: Wellington looking towards the Hutt River htps://www.wc.govt.nz/maori/wellington/andoftara.html

Figure 3.17 https://www.wcl.govt.nz/maori/wellington/bigtearopa.jp

Figure 3.19 'Overlooking Te Aro, Wellington', c. 1860, Photograph. Photographer unidentified https:/i.pinimg.com/236x/43/37/30/4337306774136878ccaf4440995b5982-maori-kiwi.jpg

Figure 3.20 'Looking East, down Courtenay Place from the tip of what was formerly known as Pigeon Park', 1928. https://wellington.recollect.co.nz/nodes/view/5510?keywords=

Figure 3.21. 'Photograph of Pigeon Park, from Dixon St', Wellington, taken c.1940s-1950s by Crown Studios L td of Wellington. https://natlib.govt.ne/

Figure 3.22 Te Aro Park in central Wellington (between Manners and Dixon streets) https://teara.govt.nz/en//hotograph/1288/te-aro-park

Figure 4.16 Bryan Cantley, Surface Topology Experiment, 2010. H.tps://www metalocus.es/en/news hryan-cantley-dirty-geometries-mechanical-imperfections

Figure 5.03 Paul Hillier. ‘360 degree Pā Panorama', Digital Photograph. $\begin{array}{ll}\text { Figure 5.08 } & \text { 'Rākau Whakapapa Ngāti Rangi tribe', Digital Photograph. The British Museum. } \\ \text { https://www.britishmuseum.org/collection/objectE__Oc1854-1229-22. Attribution-NonCommercial-ShareAlike }\end{array}$ 4.0 International (CC BY-NC-SA 4.0)

Figure 5.09 Shane Cotton, Middle North, 1997

Figure 5.09a $\quad$ hhane Cotton, Cross, 1996 Ittps://www.aucklandartgallery.com/explore-art-and-ideas/artwork/8562/cross 
Below | Featured Work in AD

Magazine, 'Emerging talents:

Training Architects', Guest edited

by Neil Spiller, 2021

Overleaf | Drawing selected to

be added to 'Tâtuhi / Drawing

Architecture: Sarah Treadwell

WILEY

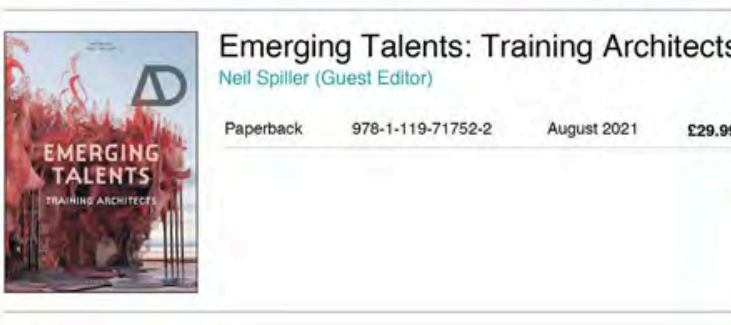

Q DESCRIPTION
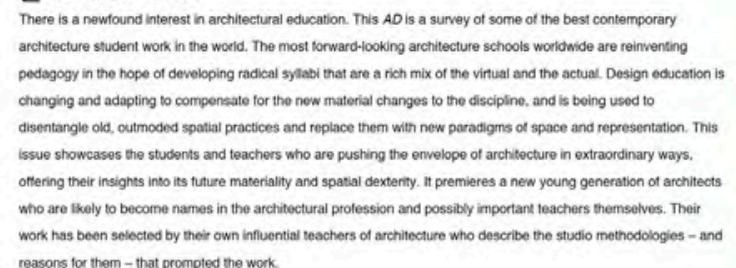

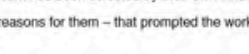

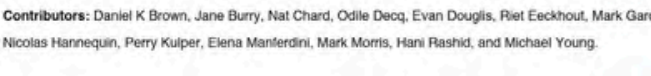

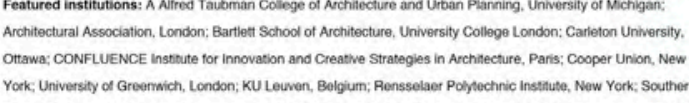

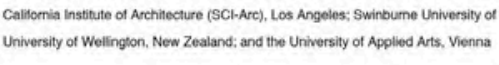

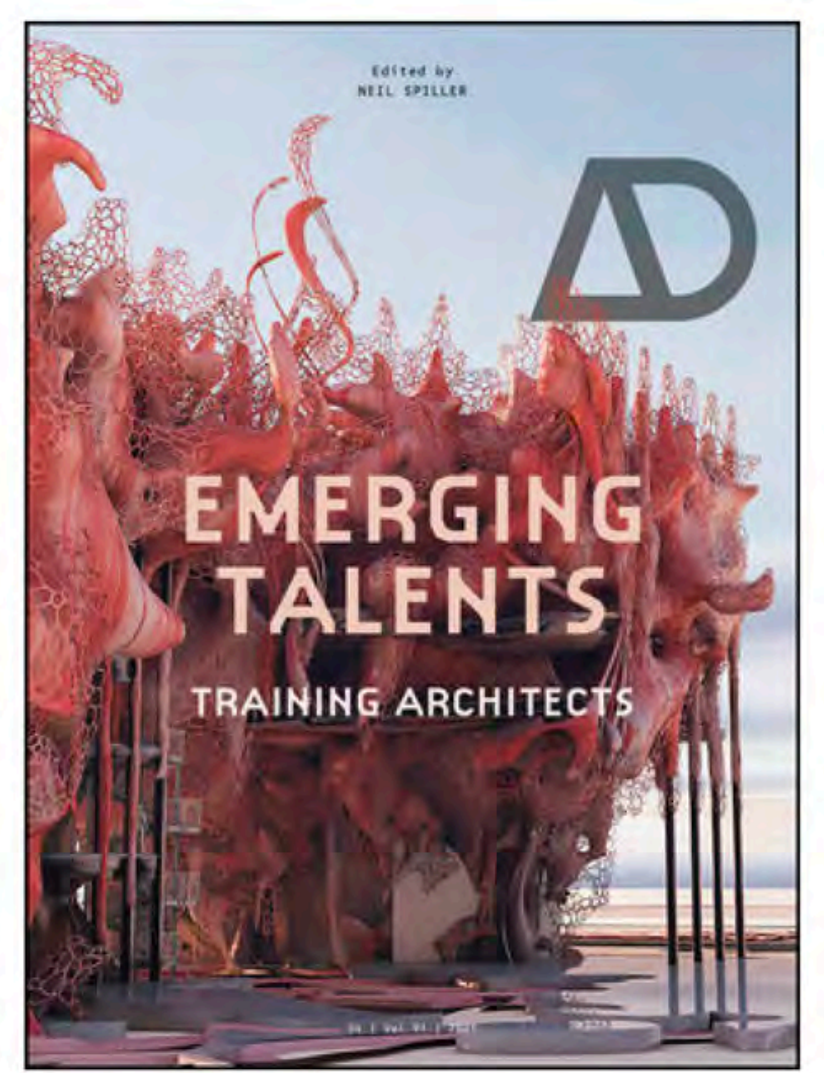

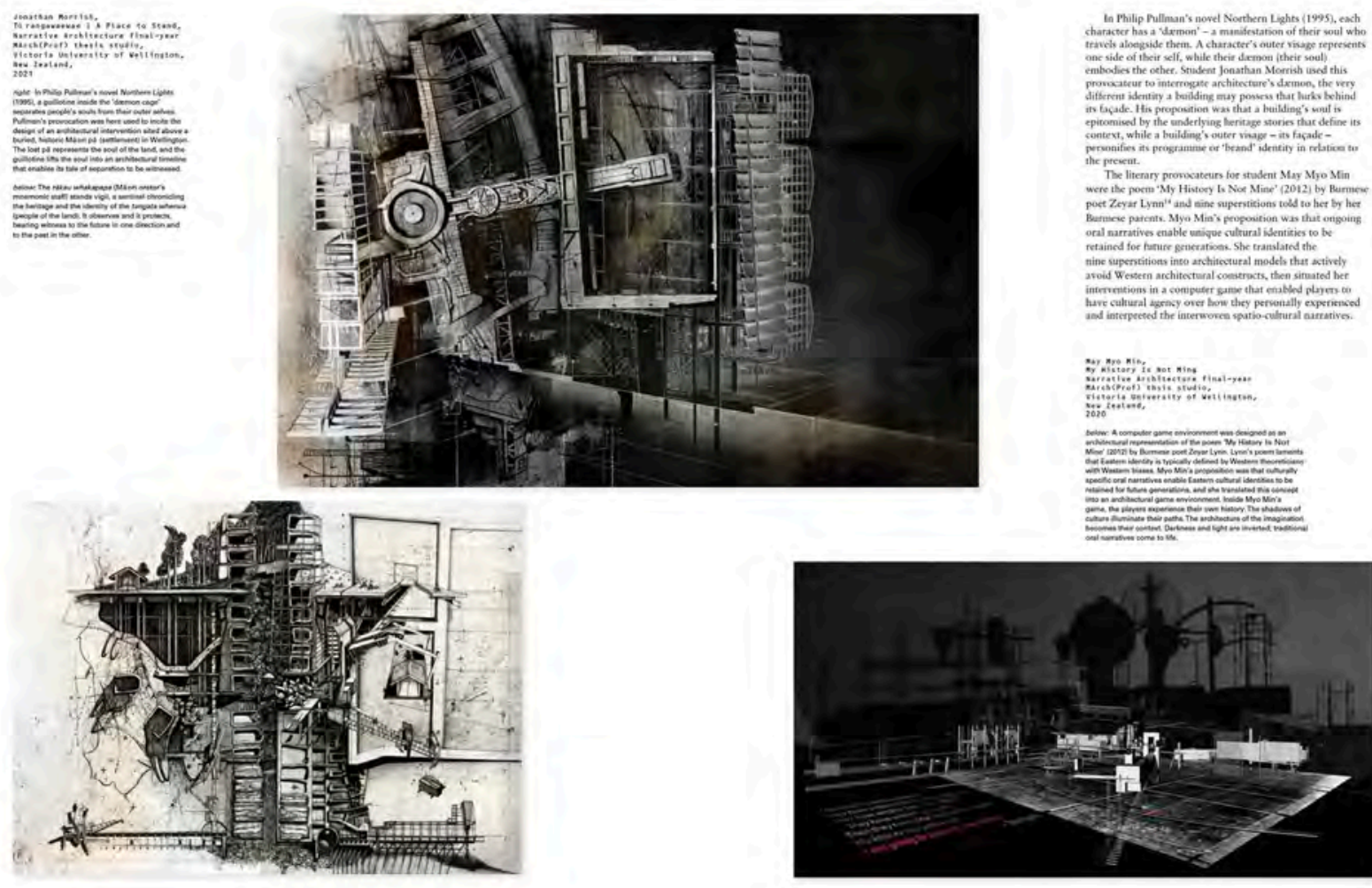




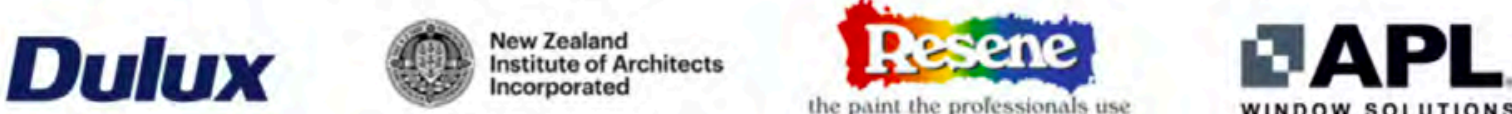

New Zealand

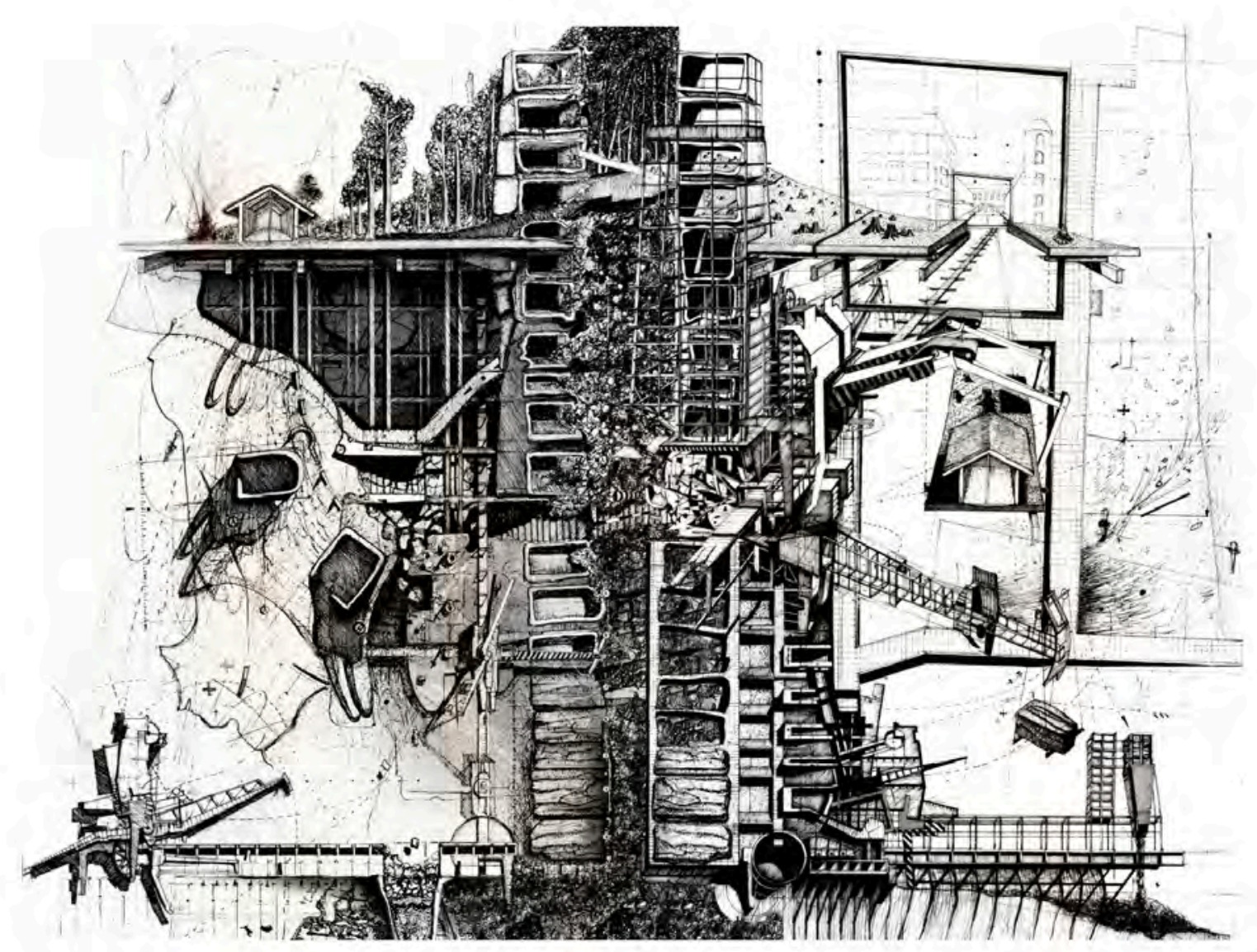

2021
Welcome to the Tätuhi/ Drawing Architecture: Sarah Teadwell Archive, sponsored by Metalcraft. This is In early 2017 Dr Sarah Treadwe retiod from academic life at The University Pf Auckland, School of Architecture and Planning, New Architecture+Women-NZ wish to make a special acknowledgement of her career in architecture. As well as recognising Sarah's extraordinary work and critical thinking we also celebrate her grace, wisdom and patience.

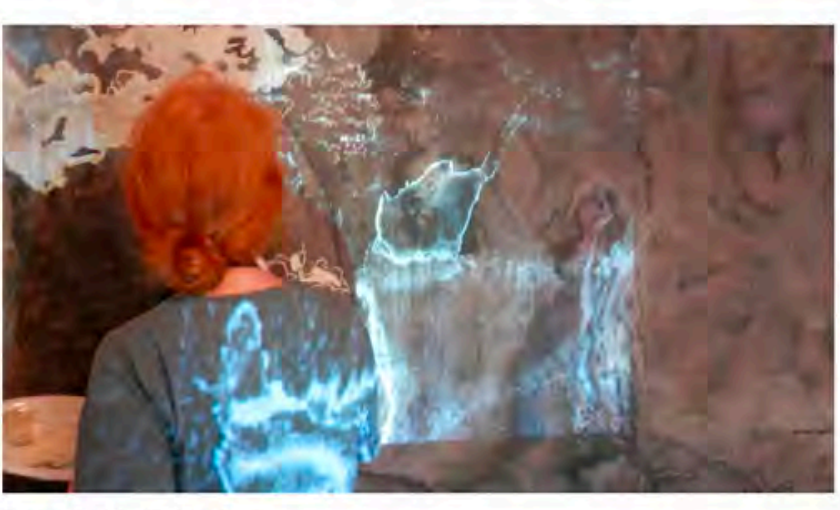

As Sarah moves into her life in art, it seems appropriate to Whnowedge her major contribution to the 'drawing culture Wichexists at $\mathrm{m}$. Ple critical approach to the use of media in architecture.

In recognition of this legacy, A+W.NZ have established this online archive, in her name.

The first drawing submitted to this archive is, of course, one of her own
The selection of each annual drawing will be made by Sarah Treadwell, and/or her team of nominated selector(s).

One drawing will be selected each year. Sarah and her nominated team may elect to add more than one drawing to the archive in any year

The annual drawing will be selected from the end of year architecture and Spatial Design graduation shows by The well as competitions such as the AAA Visionary Awards and NZIA Student Award.

The selected annual drawing will be uploaded in January of each year.

The author of the selected drawing will be asked to provide permission for the (digital) use of the drawing, in perpetuity. Copyrightremains

The author will receive $\$ 500$ for the acknowledgement of granting their permission for use of the drawing on the $A+W$ NZ website.

The author's name and date will be watermarked on the drawing. online archive, established on 26 August 2017, and is a digital storehouse for architectural drawings. The intention is to add one selected drawing peryear, so that the archive becomes a slow-building record of selected trends and time. 